\author{
Pedro José Tótora da Glória
}

\title{
ESTILO E QUALIDADE DE VIDA BIOLÓGICA EM SAN PEDRO DE ATACAMA: O QUE DIZEM OS ESQUELETOS SUBADULTOS
}

São Paulo 2006 
Pedro José Tótora da Glória

\section{ESTILO E QUALIDADE DE VIDA BIOLÓGICA EM SAN PEDRO DE ATACAMA: O QUE DIZEM OS ESQUELETOS SUBADULTOS}

Tese apresentada ao Instituto de Biociências da Universidade de São Paulo, para a obtenção de Título de Mestre em Ciências, na Área de Genética e Biologia Evolutiva.

Orientador: Walter Alves Neves

São Paulo

2006 


\section{Ficha Catalográfica}

da Glória, Pedro José

Estilo e Qualidade de Vida Biológica em San Pedro de Atacama: o que

Dizem os Esqueletos Subadultos.

217 páginas

Tese (Mestrado) - Instituto de Biociências da Universidade de São Paulo. Departamento de Genética e Biologia Evolutiva.

1. Antropologia Biológica

2. Arqueologia Andina

3. Marcadores Osteológicos

I. Universidade de São Paulo. Instituto de Biociências.

Departamento de Genética e Biologia Evolutiva.

\section{Comissão Julgadora:}

Prof. Doutor (a)

Prof. Doutor (a)

Prof. Doutor

Walter Alves Neves 


\section{Agradecimentos}

Em primeiro lugar eu gostaria de agradecer a todas as pessoas do Laboratório de Estudos Evolutivos Humanos (LEEH) que fizeram com que meu trabalho fosse muito mais agradável e produtivo.

A Rui Murrieta e Renato Kipnis por suas opiniões e sugestões.

A Mark Hubbe e Maria Antonietta Costa pelo compartilhamento de dados e válidas sugestões.

A FAPESP por seu fundamental apoio financeiro.

Ao meu orientador, Walter Neves, por suas importantes idéias e suas minuciosas correções. Sua energia e sua vigilância, foram fundamentais para impedir a acomodação e a mediocridade neste trabalho.

Por fim, agradeço aos meus pais e amigos pela paciência e pelo incansável apoio. 


\section{Índice}

Resumo

Capítulo 1 - Introdução

Capítulo 2 - Contexto sócio-cultural 9

2.1 - Informações advindas da Arqueologia 9

2.2 - Informações advindas da Antropologia Biológica 30

2.3 - Os sítios estudados 34

Capítulo 3 - Marcadores osteológicos $\quad 40$

3.1 - Hiperostose porótica 40

3.2 - Hipoplasia linear do esmalte dentário 42

3.3 - Cárie 43

3.4 - Abcesso 45

3.5 - Desgaste dentário 46

3.6 - Infecção inespecífica $\quad 47$

3.7 - Trauma 48

3.8 - Estatura $\quad 50$

Capítulo 4 - Comparação entre os períodos 51

4.1 - Material e métodos 51

4.2 - Resultados $\quad 59$

4.3 - Discussão 88

4.3.1 - Amostra 88

4.3.2 - Paradoxo osteológico 93

4.3.3 - Marcadores dentais (cáries, desgaste dentário, abcessos) 95

4.3.4 - Hipoplasias lineares do esmalte dentário 98

4.3.5 - Infecções inespecíficas 99

4.3.6 - Hiperostose porótica 100

4.3.7 - Traumas 101

4.3.8 - Estatura 101

4.4 - Síntese 102 
Capítulo 5 - Análise mundial

5.1 - Material e métodos 103

5.2 - Resultados 106

5.2.1 - Hipoplasias lineares do esmalte dentário 106

5.2.2 - Abcessos 119

5.2.3 - Cáries 131

5.2.4 - Traumas 151

5.2.5 - Hiperostose porótica 158

5.2.6 - Infecções inespecíficas 175

5.3 - Discussão 188

5.3.1 - Limitações da análise 188

5.3.2 - Marcadores osteológicos 189

5.3.3 - Hipoplasias lineares do esmalte dentário 190

5.3.4-Abcessos 191

5.3.5 - Cáries 192

5.3.6 - Traumas 193

5.3.7 - Hiperostose porótica 194

5.3.8 - Infecções inespecíficas 195

5.4 - Síntese 196

Capítulo 6 - Discussão e conclusão 197

6.1 - Relação centro-periferia 197

6.2 - Análise mundial 201

Referências bibliográficas $\quad 203$ 


\section{Resumo}

A região do Deserto de Atacama, norte do Chile, possui condições propícias para a conservação arqueológica. Uma grande quantidade de esqueletos ali bem preservados vem permitindo um intercâmbio rico entre estudos bioantropológicos e arqueológicos. Dentro desse contexto, o presente estudo concentra-se nos esqueletos humanos subadultos de San Pedro de Atacama. O universo amostral é de 90 esqueletos subadultos (menores de vinte anos) de três cemitérios diferentes: Solcor-3, Coyo-3 e Quitor-6; a datação desses cemitérios varia de 250 até 1240 A.D. A inferencia da qualidade de vida biológica foi feita através de oito marcadores osteólogicos. Duas abordagens foram realizadas neste estudo: a comparação do estilo e da qualidade de vida biológica entre períodos da pré-história atacamenha e a análise mundial. A primeira delas comparou quatro períodos distintos da pré-história atacamenha: anterior à influência do Império Tiwanaku, auge da influência Tiwanaku, fase final da influência Tiwanaku e posterior à influência Tiwanaku. A hipótese central a ser testada nesta abordagem é a de que houve uma melhoria significativa na qualidade de vida biológica na região de San Pedro de Atacama durante o auge da influência Tiwanaku. A segunda abordagem consistiu na junção dos quatro períodos em uma amostra única. Estes dados caracterizaram a qualidade de vida biológica dos subadultos atacamenhos, e foram comparados com populações do restante do mundo. Objetivou-se testar se a qualidade de vida biológica em San Pedro enquadrava-se na estratégia de subsistência agricultora. Os resultados da comparação entre os períodos corroboraram a hipótese inicial apenas para o marcador cáries, uma vez que os demais marcadores apresentaram um padrão bastante variado. Os resultados da análise mundial, por sua vez, mostraram que San Pedro de Atacama se encontra dentro da amplitude de variação da categoria “agricultores”. No entanto, foi constatado que, com exceção de cáries, os marcadores osteológicos apresentaram alta variação nas diferentes populações mundiais de uma mesma estratégia de subsistência. Os marcadores cáries, abcessos e hipoplasias em San Pedro ficaram acima da média agricultora enquanto hiperostose porótica, infecções e traumas ficaram abaixo. Em suma, encontrou-se um padrão complexo, no qual cada marcador osteológico é sensível a um conjunto de condições culturais e naturais próprias da história da população atacamenha. 


\begin{abstract}
Desert of Atacama region, northern Chile, shows excellent conditions to preserve archaeological remains. A high number of skeletons exumated allows a rich interchange between archaeology and biological anthropology. This study analyzed subadult skeletons from San Pedro de Atacama. The sample is composed by 90 subadult skeletons (less than twenty years) from three burial sites: Solcor-3, Coyo-3 e Quitor-6; they are dated from between 250 to 1240 A.D. Style and biological quality of life were infered throught eight osteological markers. Two approaches were carried out in this study: comparison of style and biological quality of life between Atacameneans prehistoric periods and world-wide groups. The first compared four prehistoric periods of San Pedro: before the influence of Tiwanaku Empire, peak of Tiwanaku influence, final period of Tiwanaku influence and after Tiwanaku influence. The main hypothesis tested in this approach is the significative improvement of biological quality of life in San Pedro de Atacama during the peak of Tiwanaku influence. The second approach joined the skeletons from the four periods in a single sample. These data caracterized the biological quality of life of Atacameneans subadults. The aim was testing if the biological quality of life in San Pedro de Atacama would be within the variation found in agricultural subsistence strategy. The results of the periods' comparison show that only caries frequencies corroborated the main hypothesis, while the other markers presented a variable pattern. Results of the world-wide analysis showed that San Pedro is within the range of agriculture category. However, it was found out that, except for caries, the osteological markers showed high variation in different world-wide populations within the same subsistence strategy. Caries, abscess and hypoplasias in San Pedro de Atacama were above the world-wide agricultural mean, while porotic hyperostosis, infections and traumas were below. In brief, it was found a complex pattern, in which each osteological marker responds to a particular group of natural and cultural characteristics of the prehistory of Atacamenean population.
\end{abstract}




\section{Capítulo 1 - Introdução}

O estudo dos marcadores osteológicos de estresse biológico insere-se em uma longa história no campo da Paleopatologia (Goodman e Martin, 2002). No entanto, a formação de uma trajetória autônoma e consistente é bem mais recente, podendo ser identificada a partir da década de 1970. Esta área vem crescendo em importância dentro da antropologia biológica. As décadas de 1980 e 1990 foram marcadas por uma euforia quanto ao poder explicativo desses marcadores; o que foi, em parte, contido por trabalhos que mostraram as sérias limitações intrínsecas e extrínsecas do material osteológico (Wood et al., 1992).

Os estudos de Paleopatologia tiveram uma profusão no começo do século XX, inclusive com grandes sínteses como a de Moodie (1923), que abordou as doenças do passado tanto em humanos como em animais. Esses primeiros estudos tinham um forte cunho descritivo, vinculando-se fortemente à ciência médica. Nos trinta anos que se seguiram, como Jarcho (1966) relata em seu livro Human Palaeopathology, houve uma ausência de contribuições significativas nessa área. A transposição das doenças atuais para o passado passou a ser questionada, pois os estudiosos da época perceberam que os sinais deixados nos ossos eram, muitas vezes, incompletos e inespecíficos, dificultando diagnósticos precisos (Buikstra e Cook, 1980).

A grande mudança de perspectiva na Paleopatologia ocorreu após tal período de descrédito quanto ao estudo das doenças no passado. No fim da década de 1960 e começo da década de 1970, surgiu uma série de trabalhos que buscava entender as doenças sob uma perspectiva populacional, trazendo aspectos culturais e ecológicos para a discussão do tema. Os trabalhos de Angel (1966) e Carlson et al. (1974), analisando a frequência de hiperostose porótica, são exemplos desse tipo de abordagem, cuja origem pode ser remontada ao trabalho de Hooton (1930) sobre Pecos Pueblo. Apesar de Hooton ter sido um dos pioneiros na perspectiva populacional, esse tipo de abordagem foi uma exceção até o trabalho de John Lawrence Angel na década de 1960.

Os anos 1960 foram marcados pelo crescimento do campo da ecologia tanto na biologia como nas áreas da arqueologia e da antropologia. Conceitos como adaptabilidade, meio ambiente e cultura como entidade adaptativa passaram a ganhar força nos estudos de populações humanas abordadas a partir de preceitos biológicos. Novas áreas de estudo 
surgiram nesse período, na ânsia de explicar comportamento humano através de parâmetros ecológicos e biológicos, como, por exemplo, a ecologia sistêmica (Rappaport, 1968) e a ecologia comportamental (Smith, 2000). Essa tendência não excluiu a Paleopatologia, que, junto com essa grande mudança paradigmática, passou a focar questões comportamentais, culturais e populacionais (Goodman e Martin, 2002).

Paralelamente ao surgimento dessa nova perspectiva populacional, os trabalhos em Paleopatologia retomaram seu vínculo com os estudos clínicos, intensificando a identificação das marcas ósseas que as doenças produzem no esqueleto (Buikstra and Cook, 1980). Esse refinamento foi bastante importante para subsidiar as inferências populacionais; grandes sínteses foram escritas nas décadas de 1970 e 1980, como a de Steinbock (1976) e a de Ortner e Puchar (1981), funcionando como grandes manuais de identificação de doença no esqueleto.

Os estudos dos marcadores osteológicos de estresse surgiram como um ramo da Paleopatologia, em um momento na qual a identificação e a descrição puramente clínica mostraram-se insuficientes para o entendimento das populações do passado. A busca pela dinâmica social e pela reconstrução do estilo e da qualidade de vida biológica de populações pré-históricas tornou-se o objetivo dos estudos dessa natureza (Neves, 1984). Nem mesmo a especificidade dos marcadores ósseos era mais necessária para esse tipo de estudo, já que a inferência a partir de marcadores de estresse com causa indefinida é suficiente para obter um panorama comparativo do modo de vida das populações passadas; além de oferecer uma visão mais realista das potencialidades dos remanescentes ósseos humanos de origem arqueológica (Souza, 1999). Esta perspectiva populacional apresenta um forte vínculo com a Antropologia, apropriando-se de conceitos como estrutura e organização social. Os resultados dos estudos de campo com populações atuais também passaram a funcionar como um bom referencial para o entendimento das condições pretéritas (Goodman et al., 1988).

A ciência da Paleoepidemiologia foi alavancada depois da publicação do livro Paleopathology at the Origins of Agriculture editado por Mark Cohen e George Armelagos em 1984. Focando tanto o aspecto teórico como o metodológico, o livro trouxe uma perspectiva populacional para uma questão relevante no âmbito do estudo da pré-história: a natureza da transição da caça-coleta para a agricultura. A partir de então as publicações na 
área aumentaram consideravelmente. Os resultados desse interesse podem ser apreciados em grandes sínteses como a de Hillson (1996), denominada Dental Anthropology e o livro Bioarchaelogy escrito por Clark Spencer Larsen em 1997. Recentemente foi publicado, em um grande esforço de padronização metodológico, um estudo comparativo com uma ampla amostra esqueletal de toda a América (Steckel e Rose, 2002). Esse estudo de grande amplitude temporal e espacial é um indicativo do fôlego que os marcadores osteológicos ainda têm no cenário da Antropologia Biológica, mesmo depois das críticas contundentes em relação às limitações de uma amostra esqueletal - a mais séria delas conhecida como o “paradoxo osteológico” (Wood et al, 1992).

Os estudos de estilo e de qualidade de vida biológica em populações pré-históricas na América do Sul foram estimulados pelos trabalhos de Walter Neves na década de 1980. Em defesa de uma nova perspectiva na Antopologia Física, Walter Neves fez a contundente afirmação de que "antropologia física pré-histórica ou reconstitui comportamento ou não é nada” (Neves, 1984:290). Esta afirmação bebeu na fonte da Nova Arqueologia da década de 1960, da qual Lewis Binford foi um dos grandes propositores (Binford, 1962).

A reconstrução do modo de vida das populações do passado envolve uma noção central para a Antropologia Biológica: o conceito de estresse. Este conceito tem um caracter integrador, já que perpassa campos como a Antropologia, a Fisiologia, a Patologia, a Psicologia e a Osteologia. A definição do termo está intimamente associada às noções de adaptação e homeostase, apresentando variações em sua elaboração ao longo do século XX.

A abordagem mais proeminente do conceito de estresse biológico foi a de Selye (1956, 1973). Ele definiu o termo como uma resposta fisiológica a uma causa inespecífica, cujas conseqüências resultam em uma doença, a qual, portanto, seria o resultado da quebra da homeostase. As idéias de Hans Seyle tiveram grande força até a década de 1980, pois tinham uma estreita ligação com as idéias biológicas que invadiram a Antropologia nas décadas de 1960 e 1970 (Irons e Cronk, 2000). O conceito de estresse é entendido, nessa visão, como uma resposta ao meio; porém, suas conseqüências quebram a funcionalidade habitual do organismo. O maior problema não é a ocorrência do estresse, mas sim a sua repetição prolongada (Goodman et al., 1988).

Durante a década de 1980, a abordagem epidemiológica na Antropologia Biológica fomentou uma diversidade de novas formas de entender e de medir o estresse. Um dos 
campos notáveis é o da Epidemiologia Sociocultural, no qual é superada a idéia do estresse focado no indivíduo às custas de uma análise populacional e cotidiana. O papel da cultura e da estrutura social foi marcante no retrabalhamento do conceito de estresse durante a década de 1980, inclusive sendo formulado e proposto, no texto de Goodman et al. (1984), o esquema utilizado pelos livros mais atuais na área dos marcadores osteológicos de estresse (Figura 1).

A transposição do conceito de estresse para o estudo de séries esqueletais préhistóricas apresenta uma série de peculiaridades. Os esqueletos apresentam no geral uma resposta tardia em relação aos tecidos moles, ou seja, apenas eventos de estresse bastante intensos ou muito específicos deixam marcas nos ossos. Outra característica é a costumeira ausência de causalidade específica para as marcas ósseas, assim como a dificuldade de se diferenciar se essas marcas são respostas ao estresse ou se são conseqüências de uma resposta do estresse (Goodman et al., 1988). Contudo, essas limitações não impedem que se chegue a conclusões significativas a partir dessa categoria de marcadores osteológicos (ver Larsen, 1997).

Por fim, cabe ressaltar que estresse é um conceito associado ao de adaptação, porém extrapola o seu significado ao considerar os custos e os limites da adaptabilidade. Nessa mesma linha, Goodman et al. (1988) argumentam que é preciso superar o conceito adaptativista de estresse, ao considerar as condições biológicas e sociais que limitam a plena adaptação do organismo ao meio.

A análise do estilo e da qualidade de vida biológica empreendida neste estudo foi feita através de marcadores osteológicos de estresse a fim de inferir as condições sob as quais viveu a população analisada. Os marcadores osteológicos utilizados neste trabalho foram: cáries, desgaste dentário, abcessos, hipoplasia linear do esmalte dentário, infecções inespecíficas, traumas, hiperostose porótica e estatura.

Tais marcadores foram analisados sob uma perspectiva populacional, que privilegia os princípios epidemiológicos em detrimento de um enfoque individual descritivo. O cerne deste trabalho é a reconstrução do estilo e da qualidade de vida biológica da população atacamenha entre 250 D.C. e 1240 D.C.. Sob os preceitos da 


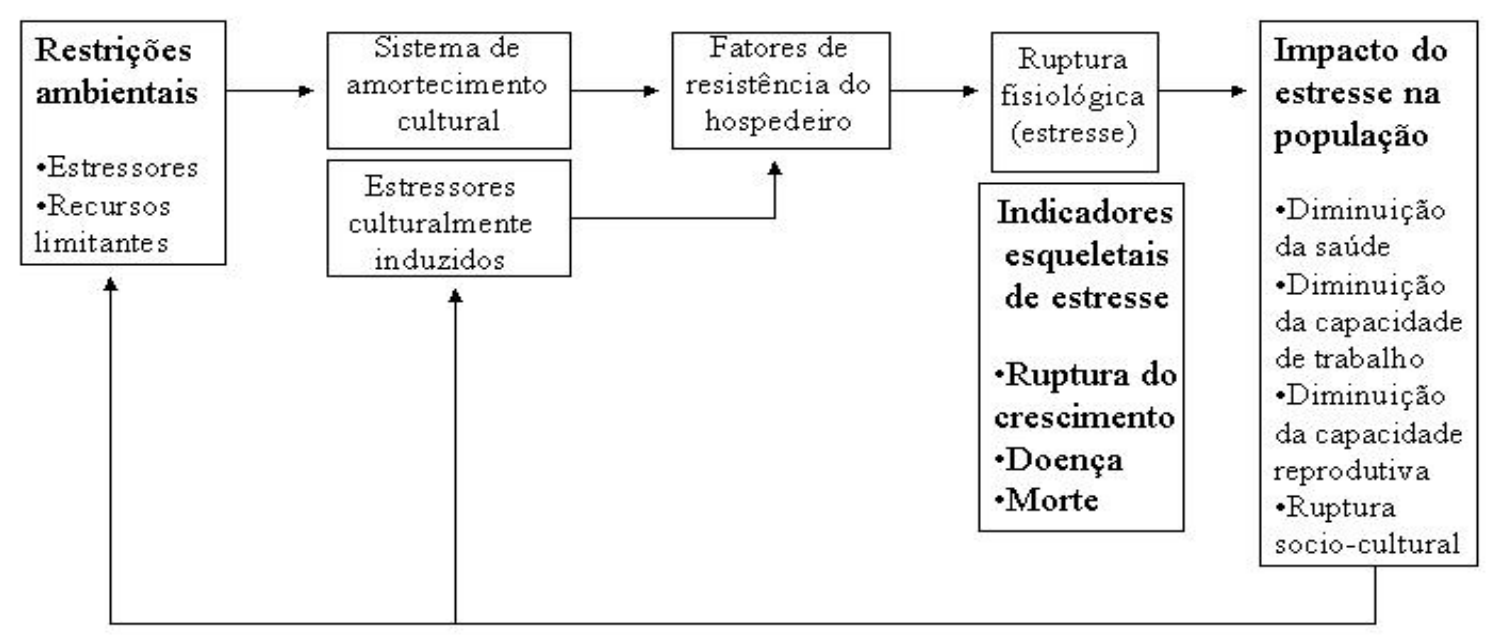

Figura 1 - Modelo para o estudo do estresse biológico em populações esqueletais, adaptado de Larsen (1997).

Bioarqueologia (Larsen, 1997), ele utiliza esqueletos humanos de origem arqueológica como fonte de dados.

O trabalho está estruturado em torno de dois grandes objetivos. O primeiro deles refere-se ao teste de uma hipótese específica originada a partir dos trabalhos de cunho bioarqueológico já realizados na região do norte do Chile (Neves e Costa, 1999; ver Capítulo 2). A partir de uma série de estudos com a parcela adulta da população atacamenha sugeriu-se a hipótese de que o período sob influência do Império Tiwanaku, entre 480 D.C. e 920 D.C., no Deserto de Atacama, é o que apresenta os melhores índices locais de qualidade de vida biológica. O teste desta hipótese nos subadultos foi feito dividindo-se os mil anos da pré-história atacamenha (250 D.C. - 1240 D.C.) em quatro períodos, comparando-os quanto à ocorrência de cada um dos sete marcadores osteológicos 
utilizados. Os resultados dessa comparação serviram como base para a compreensão da relação entre o centro do Império Tiwanaku e San Pedro de Atacama.

O segundo objetivo consiste na caracterização do estilo e da qualidade de vida biológica da população pré-histórica (menores de 20 anos) de San Pedro de Atacama entre 250 D.C. e 1240 D.C., visto através dos subadultos. Para cada um dos marcadores osteológicos foi calculada a freqüência de ocorrência por faixa etária. A incidência de cada marcador osteológico nas diversas faixas etárias entre 0 e 20 anos foi a base para a caracterização do estilo e da qualidade de vida biológica dos subadultos atacamenhos naquele período; assim como um referencial para a comparação com dados de outras populações que apresentam características ambientais e culturais diversas. A comparação focará na existência ou não de diferenças entre os subadultos de San Pedro de Atacama e as populações agricultoras do restante do mundo, testando para isso a capacidade dos marcadores de distinguir as diferentes estratégias de subsistência. Desta forma, objetiva-se, a partir das freqüências dos marcadores osteológicos do restante do mundo, compreender melhor o estilo de vida da população atacamenha sob uma escala planetária. Este tipo de análise, na qual se realiza uma comparação entre dados de diferentes culturas, tem papel central em certas linhas antropologicas, uma vez que se deseja estabelecer padrões gerais de semelhanças e diferenças entre as culturas (Ember e Ember, 1998).

Os dois objetivos visam a caracterização da população pré-histórica atacamenha de formas diferentes; o primeiro deles em um maior aprofundamento na pré-história regional, e o segundo, em uma maior amplitude geográfica e temporal. 


\section{Capítulo 2 - Contexto Sócio-Cultural}

\section{1 - Informações advindas da Arqueologia}

A região de San Pedro de Atacama, norte do Chile (Figura 2), localiza-se em um ambiente extremamente seco, conhecido como "puna desértica”. As condições climáticas são bastante desfavoráveis à ocupação humana, posto que a disponibilidade de água é muito reduzida (menos de $100 \mathrm{~mm}$ anuais) (Llagostera, 1996). As margens do Rio Loa e do Rio San Pedro são os locais mais propícios para uma ocupação humana sustentável, ocorrendo no curso do último, a formação do Salar de Atacama, cuja concentração populacional na pré-história merece destaque. O Salar de Atacama constitui-se de uma série de oasis, nos quais a disponibilidade de água, apesar de baixa, é permanente ao longo do curso do Rio San Pedro (Figura 3) (Llagostera e Costa, 1999).

A importância arqueológica do Deserto de Atacama é devida menos à grandiosidade arquitetônica ou à sua densidade populacional, e mais à incrível capacidade do solo e do ambiente de preservar materiais arqueológicos com alta qualidade, muitas vezes conservando tecidos e madeira, que em outras circunstâncias são altamente perecíveis. A preservação de grande quantidade de esqueletos humanos é outro diferencial da arqueologia atacamenha, permitindo que estudos bioantropológicos enriqueçam e complementem os conhecimentos obtidos pelo estudo da cultura material e vice-versa. A excelente preservação do material arqueológico e bioarqueológico é devida a um solo com alta concentração de sal e a um clima extremamente árido (Costa-Junqueira et al., 1998).

A ocupação do norte do Chile vem desde a transição Pleistoceno/Holoceno. A primeira evidência de ocupação data de 8690 a.C. em um abrigo sob rocha chamado Cueva de Tuina (Llagostera, 2004). Os primeiros habitantes da região de San Pedro de Atacama eram caçadores-coletores que seguiam os animais através dos grandes cursos de água (rios e lagos), além de coletarem frutos conforme a disponibilidade estacional (Núñez, 1992).

A partir de 7500 anos a.C. começaram a ser encontrados os primeiros cemitérios e assentamentos ao ar livre na região, mas não no interior do salar propriamente, indicando uma maior densidade populacional e um maior controle sobre as adversidades climáticas. 


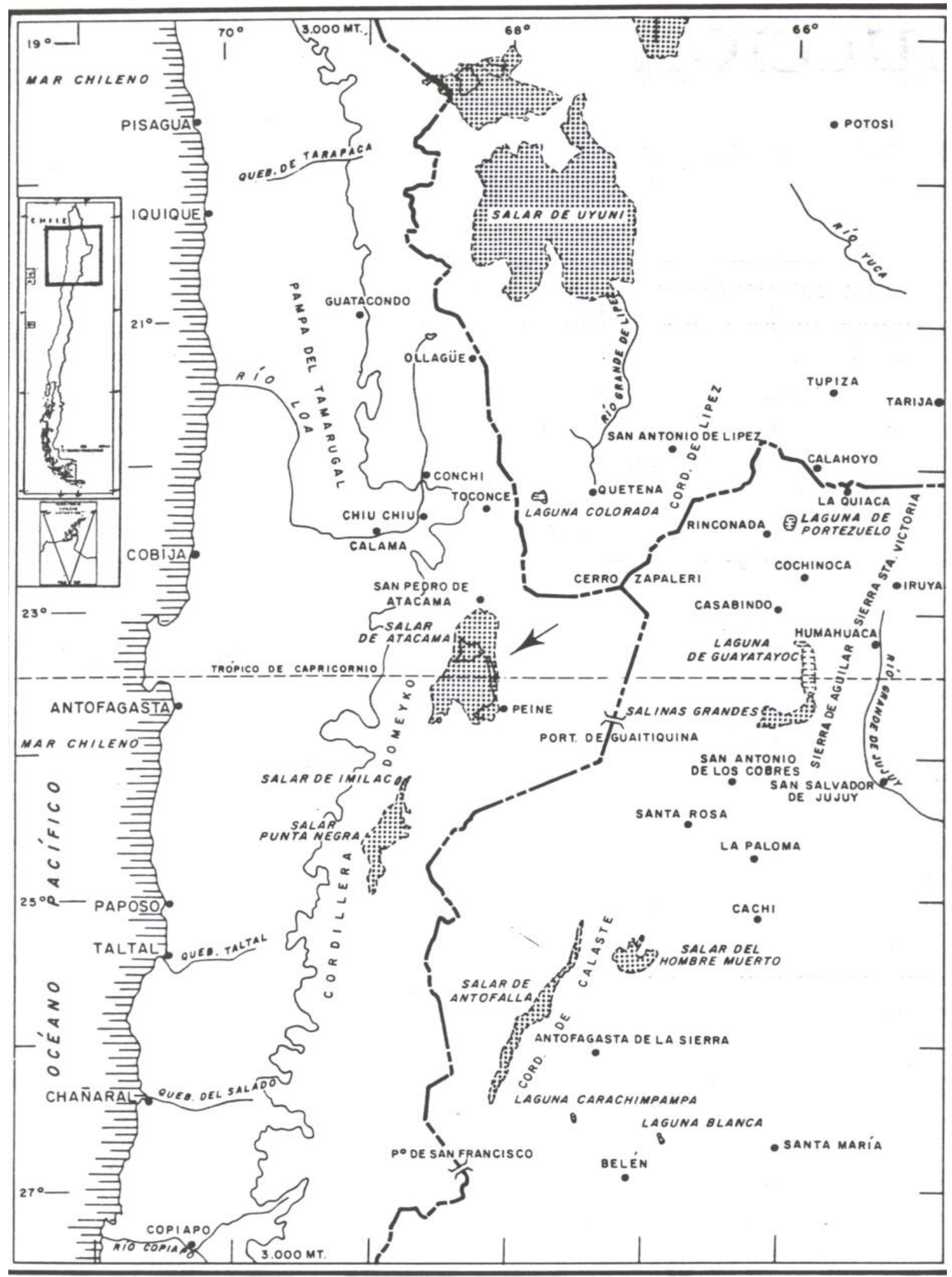

Figura 2 - Mapa do norte do Chile, com destaque para o salar de Atacama (seta). 


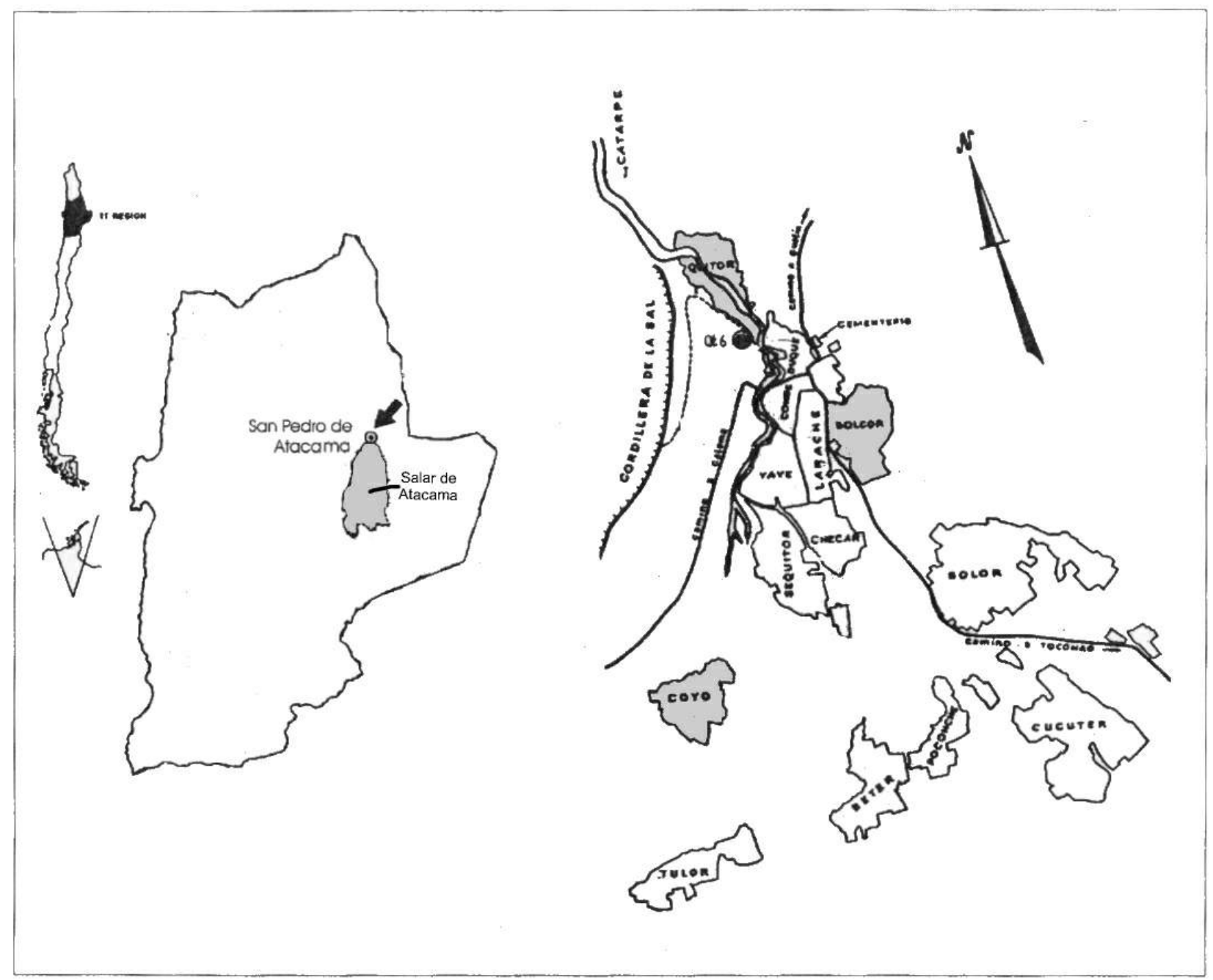

Figura 3 - Salar de Atacama, destacando em sombra os três sítios analisados neste trabalho: Solcor, Coyo e Quitor. 
Em Tambillo esses caçadores utilizavam a obsidiana para fazer instrumentos lascados, como perfuradores, raspadores e pontas. Caçavam aves, camelideos e roedores, e moíam seus alimentos em pilões cônicos.

A partir de 6000 a.C. houve um aumento da aridez na região, exigindo que seus habitantes se deslocassem por grandes extensões em busca de locais mais úmidos. A região do Deserto do Atacama foi praticamente abandonada (Nuñez et al., 2002; Llagostera, 2004). A recuperação da ocupação na região começou a partir de 4000 a.C. com os caçadores de Confluência e Isla Grande, que viviam em sítios ao ar livre e caçavam e moíam vegetais coletados (Núñez, 1992).

O período entre 3000 e 1200 anos a.C. é representado arqueologicamente pelos caçadores de Tulán. Possuíam assentamentos mais adensados nos quais viviam em residências com estruturas circulares. A subsistência era baseada na caça de camelideos e na coleta de algarrobo (Prosopis pallida) e chañar (Geoffroea decarticans). Praticavam uma mobilidade transumântica, desde o salar de Atacama até os lagos de Meniques e Miscanti na alta puna (Núñez, 1992, 1995). Foi neste período que em Puripica apareceram os primeiros sinais de domesticação de camelideos, porém de forma ainda incipiente. Tanto em Puripica como em Tulán, assentamentos fora do salar, surgiram as primeiras manifestações de arte gravada em rochas, ocorrendo, no primeiro, petróglifos representando as primeiras lhamas domesticadas (Figura 4) (Núñez, 1992). O início da domestificação de animais e vegetais estava intimamente relacionado com um período de melhora das condições climáticas no Atacama; a data desse evento gira em torno de 1500 a.C., sendo um pouco mais antiga para os animais e um pouco mais recente para as plantas (Llagostera, 2004).

As pesquisas realizadas em sítios habitação na região de Tulán revelaram alguns dos hábitos alimentares e manufatureiros desses caçadores-coletores. Holden (1991) utilizou material do interior do intestino, de coprólitos e de amostras de flotação para identificar os tipos vegetais mais consumidos nos sítios de Tulán. Os resultados do seu estudo indicaram a semente de cactus do gênero Opuntia, rizomas de plantas do gênero Schoenoplectus e sementes de Sisybrium como os vegetais mais consumidos àquela época; foram encontrados poucos exemplos de plantas domesticadas. Tal estudo apontou uma ocupação sazonal dos sítios analisados; somente as espécies encontradas em seu entorno 
13

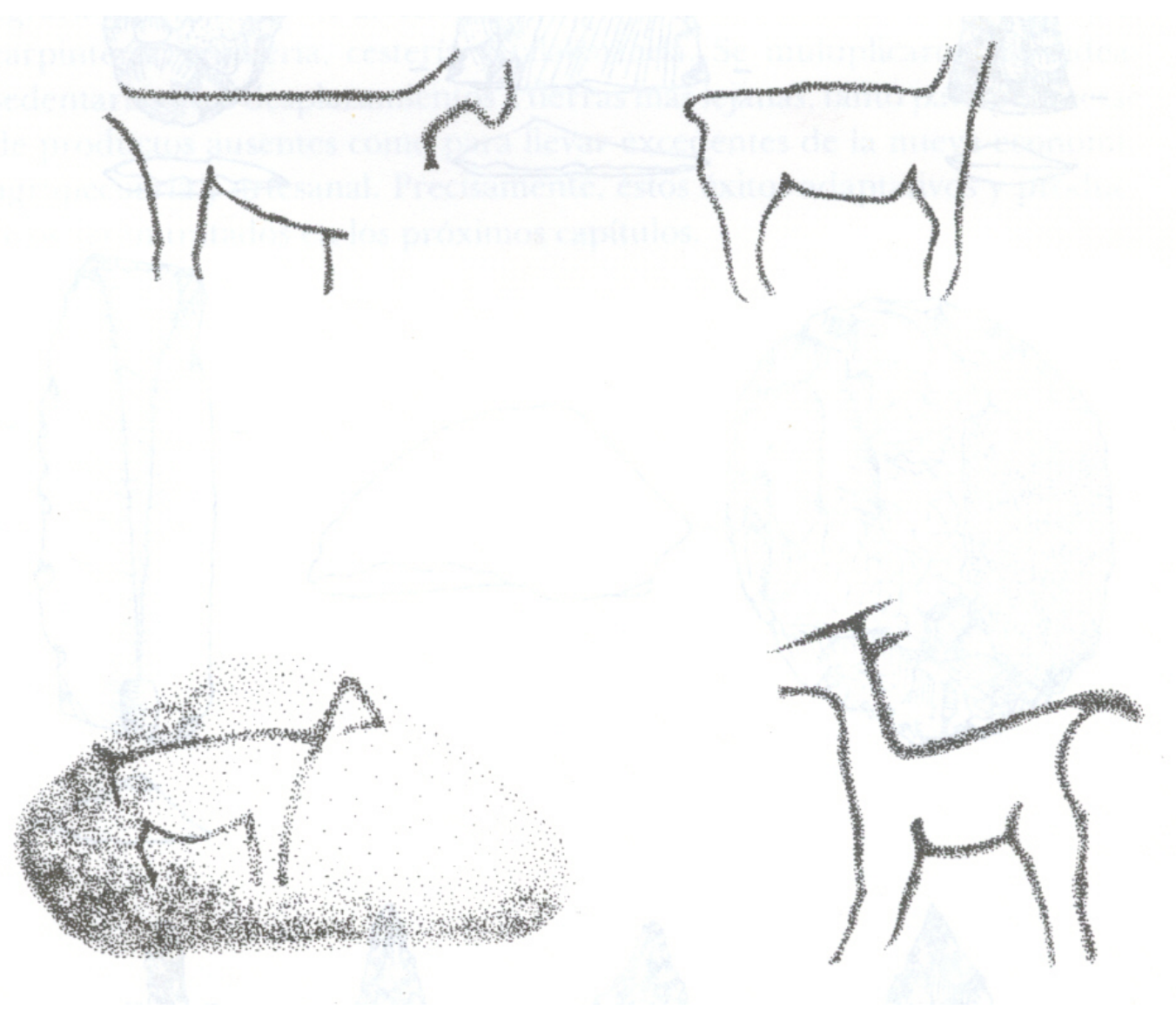

Figura 4 - Gravações de lhamas feitas pelos primeiros pastores de Puripica (adaptado de Núñez, 1992).

eram coletadas. O trabalho de Dransart (1991), por sua vez, analisou as evidências de utilização de subprodutos dos camelídeos, como carne, ossos, couro e lã. Através da compilação dos dados dos sítios Tulán e Puripica, o autor concluiu que a lã e o couro eram produtos muito utilizados na confecção do vestuário, em detrimento à utilização de fibras vegetais. Apesar da técnica de manufatura ainda não apresentar grande elaboração, os caçadores-coletores já usavam, em grande quantidade, os subprodutos dos camelideos.

No período entre 1200 e 500 a.C. ocorreram as ocupações formativas antigas, caracterizando-se pela criação de camelideos, pela coleta de chañar e algarrobo, e pela horticultura em pequenas parcelas. Nesse período os assentamentos eram de caracter semi- 
permanente com aldeias de maior complexidade arquitetônica. O pastoreio e a coleta eram as atividades principais, relegando a agricultura a uma atividade complementar. Isto está bem evidenciado em Tulán e Tilocalar, mas não no oasis de Tilomonte, já que esse apresentava condições mais propícias para a agricultura. Nessa época, apareceram sinais inequívocos de trabalho sedentário, exploração de ouro e cobre, e o surgimento da cerâmica monocrômica e grossa (Núñez, 1992, 1995). No sítio Tulor-54 foi encontrada cerâmica negra polida grossa, que mais tarde tornou-se uma marca da cultura atacamenha. A cerâmica corrugada com tiras superpostas também foi achada em sítios desse período, junto com a cerâmica incisa e modelada, evidenciando um intercâmbio entre as selvas orientais da Argentina e da Bolívia e San Pedro de Atacama (Nuñez, 1992).

A partir de 500 a.C. iniciou-se o desenvolvimento da cultura San Pedro, que marca o início da ocupação do salar propriamente dito. Os assentamentos dessa cultura são caracterizados pela dispersão e pela descontinuidade, visto que as condições climáticas e geográficas do deserto de Atacama possibilitavam poucos locais para o estabelecimento de populações humanas (Núñez, 1992; Llagostera, 1996). Os ayllos, oasis cujas temperaturas são mais quentes, os solos mais extensos e úmidos, e possuem regiões sombreadas por grandes árvores, ofereceram à agricultura boas condições para o seu desenvolvimento (Núñez, 1992).

A sequência temporal de fases que é usada para subdividir a cultura atacameña é baseada em Berenguer et al. (1986), cujo trabalho baseia-se em datações por termoluminescência feitas diretamente sobre as peças cerâmicas que foram usadas para diferenciar os períodos. As sequências de Tarragó (1989) e Núñez (1992) seguem esse mesmo padrão, com a única diferença que a primeira autora separa a fase Solor em duas: Yaye (950 a 1200 A.D.) e Solor (1200 a 1470 A.D.) (Tabela 1). Recentemente, Uribe (2002) fez uma ampla revisão da cerâmica de San Pedro de Atacama e da região do Rio Loa entre 800 e 1600 A.D., com o objetivo de refinar e unificar a cronologia dessas regiões após o colapso do Império Tiwanaku. O autor buscou sair de uma perspectiva local para elaborar uma cronologia regional, já que as duas regiões apresentavam fases dissonantes. O resultado do trabalho divide o período pós-Tiwanaku em cinco fases. Porém, o trabalho ainda é muito recente para analisarmos o impacto real dessa cronologia em San Pedro de Atacama. 
Tabela 1 - Seqüência cronológica de San Pedro de Atacama segundo Myriam Tarragó.

\begin{tabular}{|c|c|c|}
\hline Data A.C./A.D. & Períodos dos Andes Centrais e do norte do Chile & Fases de Tarragó \\
\hline 1470 & Horizonte Tardio (Inca) & Catarpe Inca \\
\hline 1200 & Intermediário Posterior (Desenvolvimento Regional) & Solor \\
\hline 950 & & Yaye \\
\hline & & Coyo \\
\hline $\begin{array}{l}700 \\
400\end{array}$ & $\begin{array}{l}\text { Horizonte Médio } \\
\text { (Tiwanaku) }\end{array}$ & Quitor \\
\hline 100 & \multirow{3}{*}{$\begin{array}{l}\text { Intermediário Anterior } \\
\text { (Formativo Posterior) }\end{array}$} & Sequitor \\
\hline $\begin{array}{l}0 \\
300 \\
\end{array}$ & & Toconao \\
\hline 500 & & Fase hipotética \\
\hline
\end{tabular}

Os primeiros assentamentos da cultura San Pedro ocorreram em Tulor (200 a.C.) e em Toconao (400 a.C.), ambos oasis. A agricultura, pela primeira vez, estava presente como uma das atividades primárias (cultivo principalmente de milho) e, associada a ela, ocorria a criação de lhamas e a coleta de algarrobo e de chañar (Llagostera \& Costa, 1999). As cerâmicas características desse período inicial são os vasos roxos polidos (Figura 5), e as urnas e vasos negros polidos de paredes grossas, tamanho grande, corpo ovóide e base cônica, muitas com rostos modelados no exterior (Berenguer et al., 1986). A cerâmica típica é a monocrômica. Porém, em casos excepcionais, encontrou-se também cerâmica policrômica advinda de intercâmbio com populações a leste de San Pedro de Atacama (Núñez, 1992).

O comércio entre as diferentes regiões do norte do Chile, norte da Argentina e sul da Bolívia foi crucial para a sobrevivência das populações humanas no Deserto de Atacama. Uma rede complexa de relações comerciais, culturais, religiosas e migratórias permitiu que produtos e costumes estrangeiros penetrassem na sociedade atacamenha. $\mathrm{O}$ contato entre as regiões altas e o litoral é evidenciado pela presença de peixes e conchas 


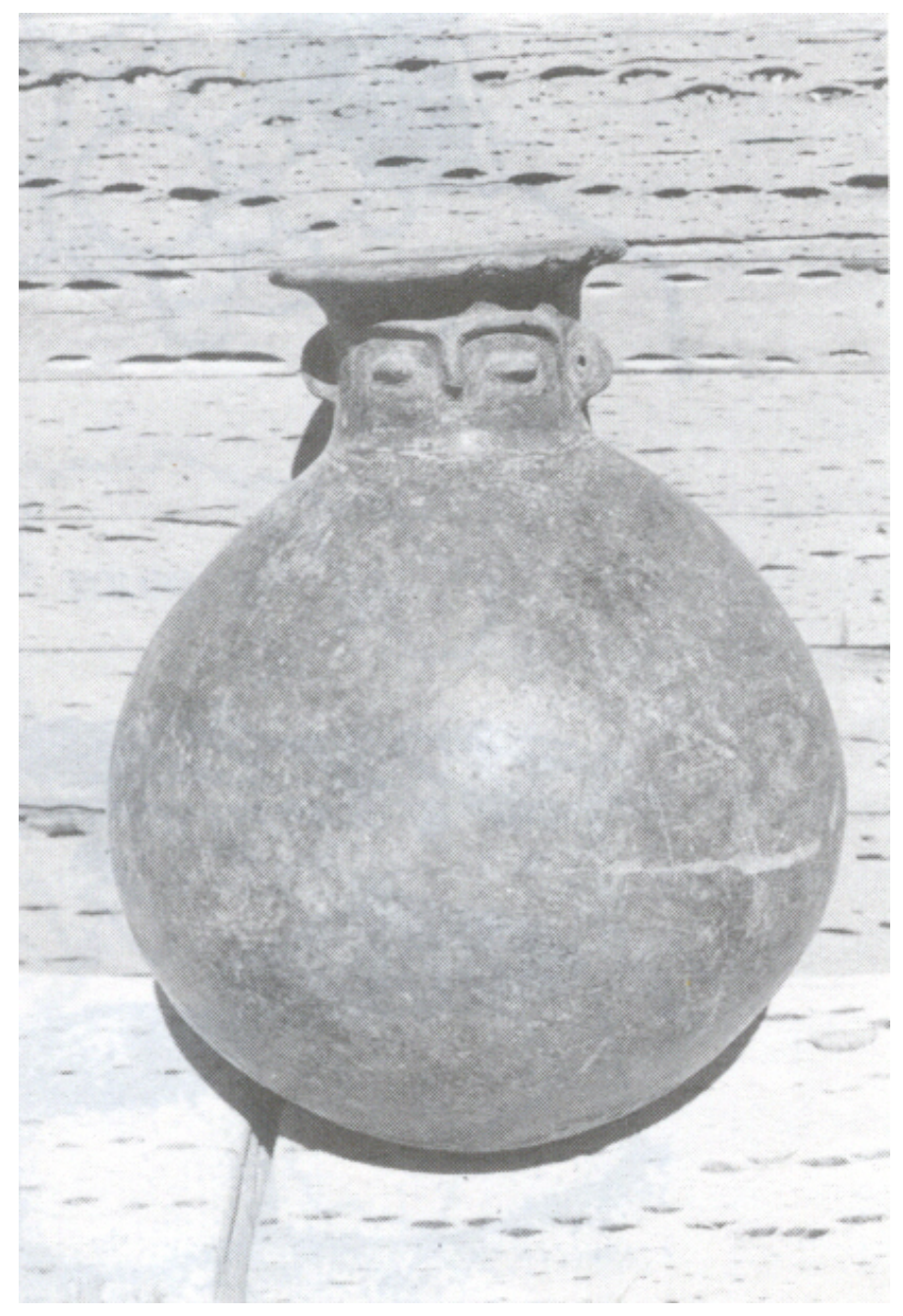

Figura 5 - Vaso Roxo Polido do Ayllo de Larache (adaptado de Núñez, 1992).

marinhas nas regiões altas; estas forneciam em troca produtos da metalurgia. A complementaridade entre os grupos populacionais era uma forma de superar a escassez de recursos e de integrar locais com diferentes riquezas. Durante a existência da cultura atacamenha houve um período no qual essas relações comerciais atingiram o seu auge, no momento em que o Império Tiwanaku exerceu grande influência nessa teia de relações transandinas. Esse período se iniciou na fase Quitor (400 a 700 A.D.) e alcançou o auge na fase Coyo (700 a 950 A.D.) (Núñez, 1992; Llagostera, 1996). 
A influência do Império Tiwanaku, cujo centro de poder estava localizado às margens do lago Titicaca, na Bolívia, foi inicialmente notada na fase Sequitor (100 a 400 A.D.), porém de forma bastante incipiente. Essa fase foi marcada por um desenvolvimento regional bastante acentuado (Llagostera, 2004). A cerâmica negra polida de base cônica com rostos antropomórficos sobre o colo e os cachimbos de cerâmica são marcas dessa fase; encontrou-se também, na região de Tulor, cerâmica café e cinza polida (Berenguer et al., 1986; Nuñez, 1992). A agricultura apresentava-se mais estável e diversificada, baseando-se no milho, no feijão, na abóbora, na cabaça, na pimenta, entre outros cultivares. As atividades artesãs se multiplicaram, incluindo manufatura de têxteis, instrumentos de ossos, de metais e cestaria (Núñez, 1992).

Há uma grande discussão sobre qual foi o papel que Tiwanaku desempenhou de fato na cultura atacamenha tanto na fase Quitor como na fase Coyo. Teria havido deslocamento populacional do centro do Império para San Pedro de Atacama? Ou a influência do Império foi apenas de cunho religioso e comercial? É notória, no registro arqueológico durante essas fases, a presença de objetos com a iconografia típica de Tiwanaku, tanto em tabletas e em tubos para inalação de alucinógenos (parafernália alucinógena) quanto na cerâmica e nos tecidos. Porém, ainda há certa dúvida se esses objetos pertenciam a uma população imigrante ou se foram simplesmente incorporados pela população local (Llagostera et al., 1988; Llagostera, 1996). Rodman (1992) estudou a inserção de objetos tiwanakotas em San Pedro de Atacama através da análise dos tecidos resgatados do sítio Coyo-Oriente (639 910 A.D.). A autora encontrou dois conjuntos têxteis bastante distintos e sincrônicos: um deles apresenta vestuário com traços locais e o outro vestuário com traços tiwanakotas. Rodman propôs uma distinção étnica entre eles, relacionando-os a uma possível imigração para San Pedro de Atacama (ver porém Llagostera, 1996).

A relação existente entre o Império Tiwanaku e as populações circundantes tem sido foco de um longo debate. Um grande marco teórico nessa discussão foram as idéias de John Murra, que tiveram bastante força na década de 1970. Ele defendia o modelo dos arquipélagos verticais, pelo qual a população do centro ocupava e controlava áreas periféricas pertencentes a pisos ecológicos distintos, a fim de obter recursos que complementassem aqueles disponíveis no centro populacional (Murra, 1972). Baseado, originalmente, em estudos etnohistóricos, esse modelo foi ampliado para a arqueologia a 
fim de explicar a relação das populações ao redor do lago Titicaca com as suas vizinhas, principalmente aquelas que ocupavam altitudes mais baixas como as do vale de Moquegua e as da região de Arica, ao norte do Salar de Atacama. A formação de enclaves coloniais nessas regiões sugeriria, a partir do modelo de Murra, um império altiplânico politicamente interventor, caracterizado pela expansão populacional com fins exploratórios.

Um modelo alternativo ao do arquipélago vertical foi proposto por David Browman, que o chamou de modelo altiplânico (Browman, 1980). A idéia básica do seu modelo é destacar a importância das redes comerciais entre as diversas populações andinas, enfatizando o fluxo de mercadorias ao invés de pessoas. Em oposição ao modelo vertical de John Murra, David Browman chamou o seu modelo de horizontal, já que o fluxo de mercadorias acontecia também em zonas de mesma altitude, desde que apresentassem uma produção econômica complementar em relação aos vizinhos. No caso específico de Tiwanaku, o autor justificou a não aplicabilidade do modelo vertical para o altiplano boliviano devido à enorme distância que separa o litoral do centro de Tiwanaku (cerca de $800 \mathrm{~km}$ ), considerando, portanto, os altos custos sócio-políticos envolvidos numa possível colonização. Os dados arqueológicos apresentados pelo autor apontam para um comércio regional anterior à consolidação do Império Tiwanaku, fornecendo subsídios para a afirmação de que a reciprocidade é um fenômeno bastante antigo no sul dos Andes (pelo menos 1000 a.C.). Segundo David Browman, o auge do Império Tiwanaku representou apenas a intensificação de uma rede comercial pré-existente, que, a partir de então, passou a ser monopolizada por um centro comercial. As relações comerciais, que até o momento eram mais ou menos igualitárias, tornaram-se desiguais; Tiwanaku passou a funcionar como um importador de matéria prima e um exportador de bens suntuosos.

George Serracino também explorou a relação Tiwanaku-periferia, porém através de uma perspectiva estilística. Segundo ele, o intercâmbio entre o centro e a periferia era uma via de mão dupla. As zonas periféricas tiveram papel na formação do Império Tiwanaku, o que pode ser atestado pela antiguidade do comércio entre as populações andinas e pela manutenção de uma identidade estilística local durante o auge do Império. Esses dados conectam-se através do modelo da localidade humana, utilizado como estruturador teórico das idéias de George Serracino. O autor aplicou a sua metodologia de análise a San Pedro 
de Atacama, mostrando que, mesmo com um aumento significativo, ali, de objetos com o estilo Tiwanaku, houve a manutenção de uma identidade cultural local (Serracino, 1980).

Wallace (1980) também se debruçou sobre a natureza da relação entre o centro do “Império” Tiwanaku (as aspas justificam-se pela inadequação que o termo tinha para o autor), dessa vez detendo-se à região sul do Perú. Através de uma análise estilística do formato das vasilhas cerâmicas, das técnicas decorativas e do design da cultura material, o autor defende a idéia de que existiu uma independência estilística entre essas regiões. Dwight Wallace observou que não existem evidências de sítios intrusivos, objetos intrusivos, ou mesmo cópias de objetos de uma região para a outra, apesar de existirem similaridades quanto ao aspecto estilístico desses objetos. Ele concorda com as idéias de Browman sobre a natureza econômica do "Império" Tiwanaku. No entanto, acredita que esse elemento não é suficiente para explicar a força de integração de um centro tão complexo e com uma área de influência tão ampla. Segundo Wallace (1980), Tiwanaku era um centro simbólico, fisicamente situado no lago Titicaca, mas com sua ideologia religiosa, ritual e estilística espalhada por toda a área periférica. Para ele, a extensão da influência do estilo Tiwanaku nas regiões vizinhas foi resultado de uma civilização caracterizada pela força de seu sistema simbólico e não pela expansão político-social.

As perspectivas econômica e simbólica elaboradas para a interação entre San Pedro de Atacama e o Império Tiwanaku frutificaram nas décadas de 1980 e 1990. Nuñez e Dillehay (1979) implementaram essas abordagens ao trabalhar com a idéia de caravanas de lhamas que movimentavam pessoas e produtos ao longo dos assentamentos andinos. Utilizando o termo “mobilidade giratória”, os autores enfatizaram a importância do intercâmbio de produtos entre costa e altiplano, altiplano e selva, e entre locais de mesma altitude. A importância das caravanas de lhamas foi explorada novamente por Berenguer et al. (1980). San Pedro de Atacama funcionaria, segundo ele, como um ponto chave nas rotas de comércio entre o Império Tiwanaku e as zonas periféricas ao sul, situando-se como um local obrigatório para a passagem de caravanas comerciais vindas do Titicaca. Tais autores elaboraram um modelo no qual os chefes locais em San Pedro de Atacama tinham a função de organizar esse comércio de caravanas, e, por conseqüência, passaram a acumular bens de status social. Funcionando de forma parecida ao Kula descrito por Malinowski (1998 [1922]) nas ilhas Trobriand, os chefes de San Pedro de Atacama intermediavam a 
transferência dos bens vindos de fora para a população local, acumulando para si os mais suntuosos. Essa diferenciação social era legitimada pelo papel religioso que os chefes desempenhavam na população atacamenha, analogamente ao poder religioso que é desempenhado pelos shamans nas populações andinas atuais. Os símbolos de status estavam diretamente ligados à iconografia Tiwanaku, bastante poderosa nesse período em San Pedro de Atacama (400 a 1000 A.D.).

Apropriando-se desses modelos desenvolvidos nas décadas de 1970 e 1980 e refinando-os com dados oriundos de novas escavações arqueológicas realizadas nas décadas de 1980 em San Pedro de Atacama, o mais consensual entre os autores, hoje, é que durante a influência do Império Tiwanaku houve um rearranjo das rotas de comércio em torno desse novo polo econômico e religioso. San Pedro de Atacama transformou-se em uma importante rota de ligação entre o Império e suas regiões ainda mais periféricas ao sul. Uma intervenção colonial é pouco aceita para a relação entre Tiwanaku e a sociedade atacamenha, pois as evidências arqueológicas e bioantropológicas apontam para um forte intercâmbio cultural e religioso sem a ocorrência de intervenções armadas (Núñez, 1992; Llagostera, 2004).

A natureza das relações entre o centro do Império Tiwanaku e suas zonas de fronteira variaram conforme a localidade. Berenguer (1998), revisitando as idéias de seu texto de 1980, defendeu a existência de dois tipos de relação: colonização e clientelismo. O primeiro tipo ocorreu entre o centro de poder e a região de Arica e Moquegua. O interesse de Tiwanaku, ali, era a exploração de bens de subsistência não disponíveis no altiplano, estabelecendo para isto uma relação de elite e de colonos. Já o segundo tipo de relação refere-se à região de San Pedro de Atacama, localizada na chamada ultra-periferia do império. O interesse de Tiwanaku era essencialmente a obtenção de minerais semipreciosos, sobretudo o cobre, a fim de oferecer bens de distinção social para a elite na Bolívia. Para tais objetivos não houve a necessidade de intervenção administrativa; uma aliança com a elite local foi suficiente para satisfazer as necessidades de consumo do império. Estabeleceu-se uma relação de clientelismo, no qual a elite tiwanaku participava de uma rede de trocas comerciais com a “elite” de San Pedro de Atacama. As relações de clientelismo e de colonização apresentam uma correspondência estrutural com a presença excludente no registro arqueológico de tabletas e keros nas regiões de San Pedro de 
Atacama e Arica, respectivamente. A predominância de um ou do outro material indicaria o tipo de relação entre o centro do Império e sua periferia (Berenguer, 1998).

O estudo da complexidade social no centro do Império Tiwanaku também trouxe importantes contribuições para o entendimento do intercâmbio de produtos centro-periferia. Janusek (1999) defendeu a idéia de que Tiwanaku e Lukurmata apresentavam uma atividade manufatureira predominantemente ligada aos poderes locais. O centro de poder urbano teria a função de centralizar determinados padrões estilístico-culturais e econômicos (organizações de feiras e distribuição de produtos). O Estado apresentava um caráter integrador e hegemônico, mas, ao mesmo tempo, existia uma grande autonomia de produção e decisão em cada uma das comunidades locais. A sociedade Tiwanaku é vista por Janusek como uma multiplicidade de grupos com uma relação dialética com o poder central. Cada uma das comunidades criou relações de comércio com o exterior, que eram típicas da natureza de seus produtos e da história de sua comunidade. Ao tratarmos da relação de San Pedro de Atacama com o Império Tiwanaku, referimo-nos, constantemente, ao comércio entre a elite urbana e as zonas periféricas. Porém, o que Janusek deixa claro, é que não devemos simplificar tal relação, por causa da alta complexidade dos grupos sócioeconômico-culturais componentes da sociedade tiwanaku. Cada um desses grupos realizava de modos e alcances diferentes o comércio com o exterior, tornando incorreto considerar Tiwanaku como um bloco único e uniforme tanto de produção manufatureira como de padrão estilístico.

Os modelos que focam a heterogeneidade do Império Tiwanaku são derivados da proposição de Albarracin-Jordan (1996). Este autor buscou na etnohistória e na etnografia as raízes de sua abordagem teórica, buscando na população Aymara, que ocupou o lago Titicaca após o Império Tiwanaku, os princípios que regeram este último. Através de evidências arqueológicas da distribuição dos assentamentos, da cultura material e do sistema agrícola no centro do Império, ele defende a convivência de uma diversidade de etnias, com seus diferentes modos de produção material e cultural. O poder local tinha uma força grande no Império, sendo capaz de mobilizar recursos e mão-de-obra para a sua sobrevivência. $\mathrm{O}$ autor não nega os mecanismos de integração que uniram essas hierarquias locais em uma estrutura política maior no auge do Império, porém defende que a 
articulação aconteceu através da reciprocidade e de um determinador ideológico comum, e não através da intervenção direta ou do subjulgamento das hierarquias locais.

Janusek (2002), seguindo a linha da heterogeneidade, acrescentou novos dados da indústria cerâmica ao modelo acima. Ele mostra a relativa independência estilística da cerâmica do sítio Tiwanaku e do sítio Lukurmata (os dois principais centros urbanos do Império), inclusive mostrando variações entre as diversas localidades no interior dos sítios. Em Tiwanaku, por exemplo, ele constatou que a suntuosidade da cerâmica está diretamente relacionada à proximidade com o centro do sítio, onde estão localizadas as grandes construções. O mesmo padrão espacial foi verificado para a alimentação; os locais mais distantes do centro apresentavam maior quantidade de consumo de milho, o que pode estar ligado ao comércio desse cereal com regiões a leste de Tiwanaku. O autor destaca a grande capacidade do centro do Império Tiwanaku de atrair uma diversidade social, usando o termo "hospitalidade comensal”. O Império atraía os grupos periféricos pela sua visão de cosmos, de sociedade e de religião, e os que participavam dele ganhavam prestígio, oportunidade econômica, ou mesmo inspiração religiosa. Dessa forma criou-se uma coesão dentro da diversidade (Janusek, 2002).

Ainda nessa linha, Blom (2005) realizou um levantamento das deformações cranianas artificiais no centro do Império e em suas regiões vizinhas. Na região do vale de Tiwanaku foram encontradas tanto deformações cranianas anulares como tabulares; na região de Moquegua a deformação foi essencialmente tabular (assim como em San Pedro de Atacama); enquanto no vale do Katari (na região de Lukurmata, norte do Império) as deformações foram anulares. Essa distribuição parece formar dois grupos distintos. O primeiro deles, a oeste e sul de Tiwanaku, apresentou deformação tabular, enquanto o segundo deles, a leste e norte, apresentou deformação anular. Tiwanaku seria uma cidade localizada na intersecção desses dois grupos. Assumindo que a deformação craniana é um sinal de etnicidade, Tiwanaku poderia ser caracterizado como um espaço de convivência de grupos sociais distintos (Blom, 2005). As implicações dessa visão da sociedade tiwanaku para a relação com San Pedro de Atacama ainda não foram devidamente exploradas formalmente, mas, quando investigadas, poderão fornecer importantes insights.

Em San Pedro de Atacama, durante a influência do Império Tiwanaku, deve ter havido uma hierarquização da sociedade atacameña, pelo menos no que se refere ao status 
religioso. A presença de tabletas de inalação de alucinógenos, associada a acompanhamentos funerários elaborados, indica que seus portadores (shamans) possuíam maior status, além de participarem ativamente do comercio com regiões estrangeiras (Llagostera et al., 1988; Llagostera, 1996). O surgimento dessa hierarquia é compatível com o aumento da ocupação dos ayllos no salar de Atacama no período. Praticamente todos os ayllos estavam ocupados nessa época, inclusive os oasis mais distantes das fontes de água permanentes. Este é um indício de que o controle da água através de canais de irrigação estava bem desenvolvido (Llagostera e Costa, 1999). A hierarquização pode ter sido reforçada para lidar com essa estrutura mais complexa de assentamentos e de comércio, além de apresentar uma nítida influência dos padrões culturais e religiosos do Império Tiwanaku (Llagostera, 1996). A fase Quitor (400 a 700 A.D.) apresenta uma cerâmica negra polida clássica bastante elaborada, frequentemente com decoração de rostos estilizados (Figura 6); encontra-se também a cerâmica roxa gravada. Ambas caracterizamse pela monocromia (Tarragó, 1989).

A fase Coyo (700 a 950 A.D.) apresenta uma intensificação ainda maior da influência do império Tiwanaku em San Pedro de Atacama. Os assentamentos apresentam uma distribuição ainda mais ampla. Apesar de continuarem ocupando os mesmos ayllos da fase anterior, novos assentamentos foram estabelecidos, indicando um domínio mais apurado dos mecanismos de irrigação (Llagostera e Costa, 1999). Esses novos sítios podem estar relacionados a locais de mineração ou de trabalhos especializados, cuja ocorrência cresceu no período. A cerâmica sofreu uma simplificação em sua elaboração, apresentandose agora como negra quase polida, com paredes grossas e pouco brilhantes. Encontram-se, também, pratos negros e roxos com decoração gravada (Berenguer et al., 1986; Núñez, 1992).

A iconografia Tiwanaku é caracterizada por formas de felino, águia e peixe, muitas vezes apresentando monstros metade humano e metade animal. Uma figura recorrente foi a do sacrificador, que apresentava uma cabeça humana em uma mão e um machado na outra (Figura 7), assim como a figura de camelídeos que eram representados nos incensários. A iconografia registrada no Portal do Sol, localizado no centro do Império, foi uma marca de Tiwanaku; lá, estão representados figuras meio humanas e meio animal, de posse de ornamentos e cetros (Llagostera, 2004). As próprias tabletas alucinógenas são vistas como 

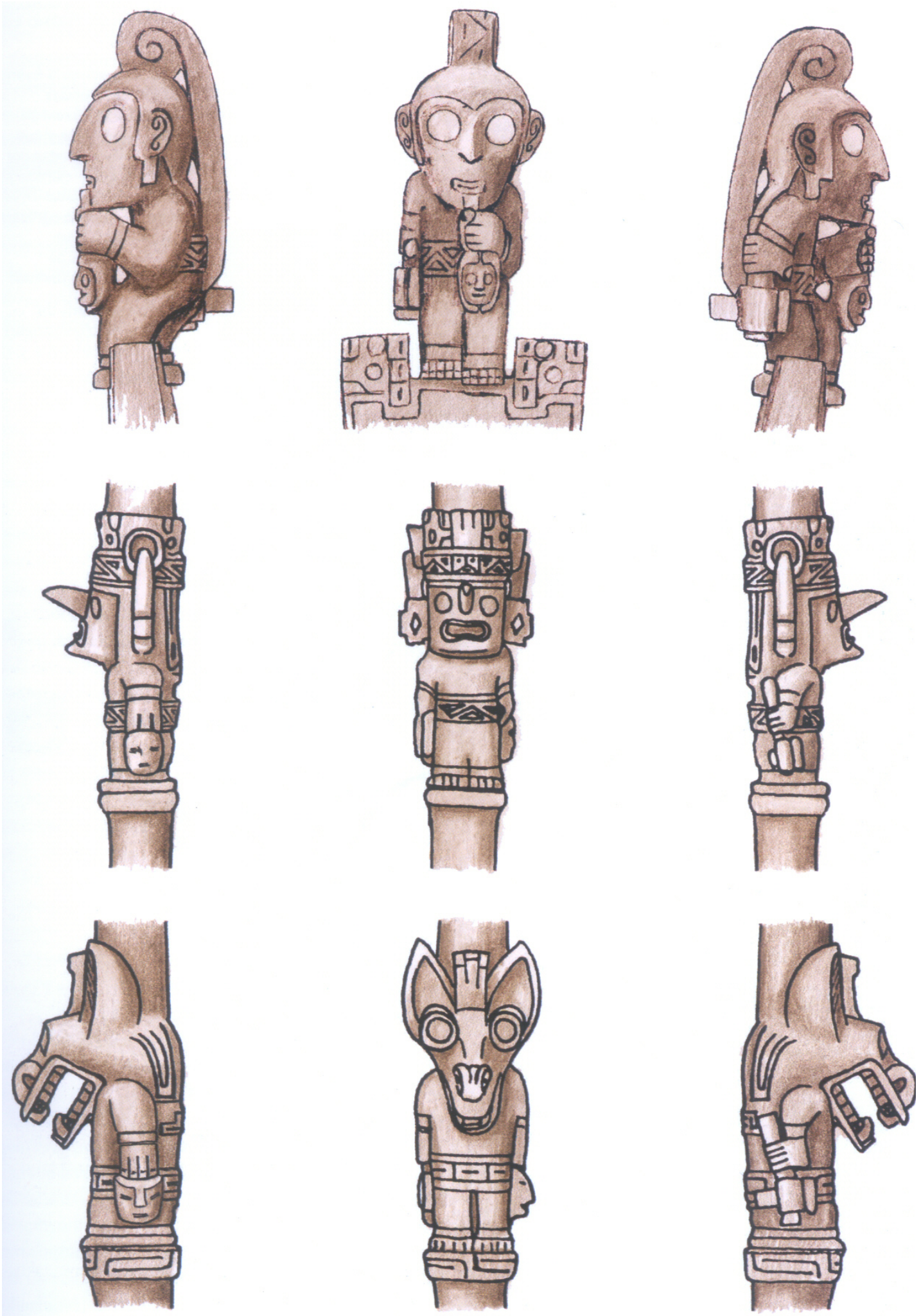

Figura 6 - Diversas figuras de sacrificadores; iconografia clássica Tiwanaku (adaptado de Llagostera, 2004). 
maquetes dos grandes monumentos do centro de Tiwanaku; a região de colocação do alucinógeno representa os pátios afundados dos templos Tiwanaku, enquanto as decorações no alto das tabletas representam a pirâmide de Akapana. Esse tipo de representação simbólica foi encontrada em todo a zona de influência do Império Tiwanaku, inclusive em San Pedro de Atacama nas fases Quitor e Coyo (Berenguer, 2000).

A fase Yaye (950 a 1200 A.D.) representa um momento de declínio tanto na quantidade de assentamentos como na cultura material. Os acompanhamentos funerários apresentam-se bastante empobrecidos. A cerâmica dessa época é muito simples e muitas vezes é substituída por cabaças (Costa-Junqueira, 1988; Tarragó, 1989).

Essa simplificação abrupta da cultura material em San Pedro de Atacama coincide com o colapso do Império Tiwanaku por volta do ano 1100 A.D.. As causas que levaram ao fim do império ainda são debatidas. Contudo, a hipótese que mais se fortaleceu na última década é a do colapso agro-ecológico, resultado de uma seca, possivelmente de amplitude continental, ocorrida após o ano 1000 A.D.. Os dados que sustentam essa hipótese foram obtidos da capa de gelo de Quelccaya, localizada entre o Lago Titicaca e a cidade de Cuzco. Somando-se a isso, foram obtidos dados paleoliminológicos do lago Titicaca que apontam uma diminuição de suas margens a partir do ano 1000 A.D.. Medidas de isótopos de oxigênio indicaram um aumento de 0,5 a $1{ }^{\circ} \mathrm{C}$ nesse mesmo período (Ortloff e Kolata, 1993).

Um segundo estudo muito importante nessa linha ambiental foi o de Binford et al. (1997). Esses autores realizaram uma cuidadosa amostragem na região de Lukurmata, no vale do rio Catari, coletando sedimentos e medindo os isótopos de oxigênio de ostrácodes, além de realizarem escavações nos campos de cultivo suspensos da região. Os resultados das inferências climáticas foram bastante coincidentes com os marcos do surgimento e da queda da sociedade tiwanaku. O período que compreende o intervalo de 1500 a.C. a 1100 A.D. é o período no qual o clima foi mais úmido; a primeira data coincidindo com o início da agricultura na região, e a segunda com o colapso do Império Tiwanaku . Apesar da transição do clima úmido para o seco, a partir de 1100, não ter sido tão abrupta, a enorme população sustentada pela agricultura nesse período agravou a proporção da crise. O sistema agrícola tiwanakota estava bem adaptado às flutuações do regime de chuvas no 
altiplano, porém, dentro de uma escala temporal menor. A grande seca não teve precedentes, superando a adaptabilidade desse sistema (Binford et al., 1997).

A importância do fator climático no colapso de Tiwanaku é amplamente aceita pelos pesquisadores da área. Porém, as reais conseqüências dessa seca ainda são um assunto que gera dúvidas; existe uma grande discussão em torno do funcionamento dos campos de cultivo suspensos em Tiwanaku. O sistema produtivo do centro do império era baseado em um complexo sistema de canais de irrigação que mantinha a renovação dos nutrientes e funcionava como um sistema térmico, que protegia a plantação contra as baixas temperaturas do altiplano. Esse sistema produzia uma grande quantidade de alimentos, comparado a outros sistemas produtivos, ao ponto de estimar-se que a capacidade de suporte dos campos suspensos do centro do Império era de 570.000 a 1.111 .500 habitantes (Kolata, 1991).

O ponto de divergência entre os estudiosos dos campos suspensos é a relação entre esse sistema agrícola e as formas de integração hierárquica da sociedade tiwanakota. Erickson (1992) e Graffam (1992) defendem a origem e a manutenção dos campos suspensos no nível dos ayllu, ou seja, a agricultura funcionava dentro de uma esfera local, na qual a capacidade do grupo familiar ou do clã era suficiente para a manutenção do sistema. Clark Erickson também trabalha com a idéia da intervenção do Estado, a partir de uma perspectiva política. O Estado se manteria às custas do trabalho das comunidades locais, através do uso da coerção em benefício da elite. Já Kolata (1986, 1991, 1993) defende que a centralização do poder na mão de uma elite foi essencial para o florescimento dos campos suspensos; essa elite, inclusive, sendo responsável pela construção de grandes sistemas de drenagem e pela mobilização de contingentes de mão de obra. O Estado para Alan Kolata teria uma função integradora, gestora, favorecendo as condições de trabalho da população. Essas visões são aparentemente contrastantes e implicam resultados diferentes no que tange ao colapso do sistema agrícola com o fim do Império Tiwanaku. Contudo, Albarracin-Jordan (1996) mostrou que, durante o auge do Império Tiwanaku, a independência do poder local sobre a agricultura pode ter coexistido tanto com uma sociedade complexa quanto com uma estrutura política de ordem maior. Stanish (1994), por outro lado, mostrou, através de uma extensa prospecção entre Juli e Pomata, no sul do Lago Titicaca, que os campos suspensos existiram antes, durante e 
depois do auge do Império Tiwanaku. Entretanto, durante a existência do Império, a proporção da população e o tamanho dos sítios em torno dos campos suspensos eram bem maiores que nas outras fases. Utilizando-se da lei de Chayanov, o autor concluiu que os campos suspensos poderiam ser viabilizados com ou sem uma elite dominante; porém, a intensidade de seu uso aumentou com a presença dessa classe dominante.

Janusek e Kolata (2004) publicaram um estudo bastante abrangente sobre os campos suspensos no vale Katari, ao norte de Tiwanaku. Os autores buscaram quebrar a visão dicotomizada de que os campos suspensos eram comandados ou pelas comunidades locais ou por um Estado centralizador. Os dados mostraram que o surgimento dos campos suspensos ocorreu antes de Tiwanaku, mas foi somente com a formação do Império que aconteceu um crescimento significativo e a intensificação desse tipo de agricultura. A maioria dos campos suspensos foi construída no período conhecido como Tiwanaku V (800 a 1150 A.D.), cuja marca foi o controle de regiões estratégicas, a intensificação da agricultura e a ocorrência de complexos festivais. A fase posterior ao Império Tiwanaku coincide com uma diminuição significativa do uso e da construção dos campos suspensos.

Os resultados desses estudos ainda não apontam um caminho consensual sobre o funcionamento do sistema agrícola tiwanaku, mas o acúmulo de dados arqueológicos sobre o tema tem elucidado alguns pontos importantes. A seca ocorrida a partir de 1000 A.D. teve graves conseqüências para o tipo de agricultura realizada em Tiwanaku, já que a água era um fator central para o modo de agricultura adotado. A seca coincide com a diminuição da produção agrícola e com o fim do Império, porém uma causualidade clara entre esses eventos ainda é obscura. Tal seca, possivelmente de caracter continental, elucida tanto a diminuição da influência de Tiwanaku em San Pedro de Atacama, como também a concentração dos assentamentos ao redor de algumas fontes de água durante o período Solor em San Pedro de Atacama.

A fase Solor (1200 a 1470 A.D.) em San Pedro de Atacama é caracterizada por uma nova expansão dos assentamentos, dessa vez distribuídos em locais de acesso aos grandes cursos de água e aos oasis. Os sítios de destaque são fortificados e são denominados pukaras. Três exemplos são Quitor-12 e Vilama - 2 e 3. Esses sítios não se localizam em locais agricultáveis, mas sim em locais estratégicos para o domínio do espaço e dos recursos (Núñez, 1995; Llagostera e Costa, 1999). Em princípio tais construções estariam 
ligadas a um aumento dos conflitos e das tensões sociais entre os ayllos. A fragmentação ocorrida após a queda do império Tiwanaku teria promovido o estabelecimento de chefes locais que exerciam poder sobre seu território, participando do comercio inter regional (Llagostera, 2004). A cerâmica típica desse período é a Dupont e a Roxa Violácea; a cerâmica Dupont foi encontrada, principalmente, com o exterior roxo alisado e com o interior negro polido. Encontra-se, também, bastante cerâmica do tipo Aiquina, com interior polido e exterior roxo alisado, e do tipo Turi, com interior e exterior roxo alisado (Uribe, 2002). Ainda existe muita controvérsia quanto ao grau de hierarquização da sociedade atacamenha e quanto ao grau de conflito que de fato existiu no período dos pukaras (Costa-Junqueira e Neves, 1990; Costa-Junqueira et al., 1998; Neves et al., 1999; Torres-Rouff e Costa, 2006).

Os estudos sobre os sítios-habitações em San Pedro de Atacama são bastante reduzidos. A grande maioria dos registros arqueológicos é advinda de sítios-cemitérios, trazendo uma grave limitação para a interpretação do modo de vida dessas populações. Exceções a essa regra são o trabalho de Llagostera e Costa (1999) sobre o padrão local de assentamento (cujo conteúdo foi incorporado ao longo deste capítulo) e o trabalho de Carrasco (2003) sobre os instrumentos de moer de San Pedro de Atacama e da região do Rio Loa, após a influência Tiwanaku. O autor faz uma descrição detalhada dos tipos de instrumentos de moer (móveis e imóveis) em cada um dos sítios analisados, adotando uma perspectiva funcional ao invés de uma análise tipológica. Os resultados de sua pesquisa mostraram uma clara diversidade de atividades nos sítios; alguns sediavam intenso processamento de produtos (Guatin e Topaín), outros, atividades de armazenamento (eg Vilama, Catarpe e Quitor), e outros ainda, processamento e consumo (Zapar, Peine e Solor). Esse tipo de especialização também é visto na utilização do minério de cobre, alguns sítios funcionando como produtores (eg Cerro Verde e Vega Salada) e outros como consumidores (eg Salar de Atacama). Os produtos que possivelmente foram processados nesses moedores foram minério de cobre, frutos de chanãr e de milho, e sementes de algarrobo (Carrasco, 2003).

Entre 1470 e 1536 A.D. a região de San Pedro de Atacama foi dominada pelos Incas. Tal domínio foi baseado em um controle político e administrativo focado na exploração de metais, usando mão de obra local. O centro político-administrativo Inca em 
San Pedro de Atacama localizava-se em Catarpe-11. O domínio desse império durou menos de um século, pois em 1536 os espanhóis conquistaram o território atacamenho e dizimaram a população local (Núñez, 1992).

Depois de vislumbrar a trajetória das populações pré-históricas que viveram na região atacamenha, é fundamental traçar uma visão global desse desenvolvimento. Utilizando o conceito de reciprocidade como eixo, pode-se afirmar que ele expressa muito bem a dinâmica de relações entre San Pedro de Atacama e o restante das populações andinas. A reciprocidade é um tema clássico na Antropologia, podendo ser considerada como uma característica universal das populações humanas (Mauss, 1974 [1923-24]; LéviStrauss, 2003 [1949]). No entanto, a rede de relações que envolve as populações andinas acentua esse intercâmbio, visto que nenhuma população andina isolada é capaz de suprir suas próprias necessidades. No Deserto de Atacama tal condição é levada ao extremo, pois a escassez local de recursos alimentares e hídricos é enorme. Durante o período arcaico, uma das estratégias de sobrevivência foi a alta mobilidade dos bandos locais em sintonia com as migrações dos grandes mamíferos, conhecida pelo termo "transumância” (Lynch, 1975); já durante o período Formativo (a partir de 1200 a.C.), quando surgiram os primeiros sinais de agricultura e de cerâmica no Deserto de Atacama, o intercâmbio de produtos, serviços e pessoas passou a ser a estratégia dominante. A reciprocidade, portanto, permeia San Pedro de Atacama e os Andes desde sua forma incipiente com os caçadorescoletores até o auge de sua expressão com o Império Tiwanaku.

Uma reflexão sobre o papel da reciprocidade em San Pedro de Atacama durante a influência do Império Tiwanaku foi realizada por Llagostera (1995). Analisando os acompanhamentos funerários filiados ao estilo Aguada no Salar (Figura 7), o autor estabeleceu uma série de vínculos entre o material estrangeiro e a população local. Seus resultados mostraram que o material de filiação Aguada estava associado a enterramentos com tabletas e a materiais exógenos de diferentes localidades, com especial destaque ao material tiwanakota. A parcela da população que detinha os bens de estilo Aguada era, portanto, a mesma que portava material estrangeiro e elementos de natureza ritualística. A reciprocidade era elemento crucial na sociedade atacamenha àquela época, com a peculiaridade de que nesse período o intercâmbio regional estava restrito aos indivíduos de alto status, que manipulavam a esfera religiosa e comercial (Llagostera, 1995). Nesse 
período, a riqueza e a suntuosidade da cultura material foram as maiores na pré-história de San Pedro de Atacama, representando o auge do intercâmbio material, ideológico e populacional na região.

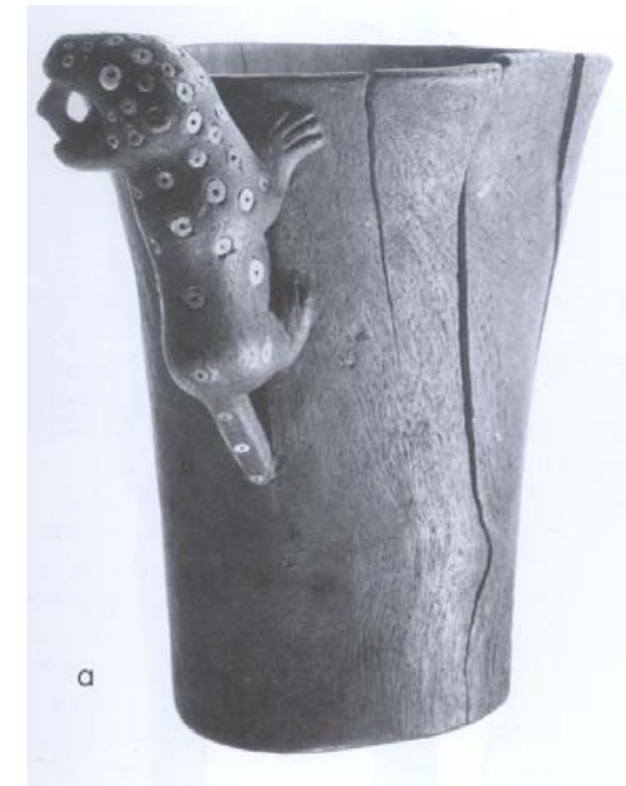

Figura 7 - Vaso-keru de madeira com um felino talhado. Objeto encontrado no sítio Quitor6, representando o estilo Aguada em San Pedro de Atacama (adaptado de Llagostera, 1995).

\section{2 - Informações advindas da Antropologia Biológica}

Os estudos bioarqueológicos já realizados em San Pedro de Atacama basearam-se na enorme riqueza de remanescentes ósseos humanos preservados na região. Essa abordagem é fundamental para complementar os registros arqueológicos, de forma a elaborar hipóteses independentes ou verificar hipóteses levantadas pelos arqueólogos.

Os estudos com esqueletos humanos na região podem ser divididos em dois tipos: 1) afinidades biológicas das populações no tempo e no espaço, através de dados métricos e 
não métricos do crânio; 2) estudos de estilo e qualidade de vida biológica, usando tanto marcadores de estresse como deformação craniana intencional.

No primeiro grupo destaca-se o estudo de Costa-Junqueira et al. (1995). Esses autores conduziram uma ampla análise, usando sete medidas faciais de 233 crânios de Solcor-3, Larrache, Coyo-3, Quitor-6 e Catarpe-1. Utilizando-se estatística multivariada, obteve-se uma matriz de distâncias entre os grupos locais divididos por sexo. Em tal estudo observou-se uma continuidade biológica durante um intervalo de tempo de 600 anos que separam os dois sítios mais distantes cronologicamente (Larache e Catarpe-1). Os habitantes dos sítios Solcor-3, Larache e Quitor-6 apresentam alta similaridade, que parece se manter no tempo e no espaço. Já os sítios Coyo-3 e Catarpe-1 parecem ter sido mais afetados por uma imigração de mulheres no primeiro caso e de homens no segundo; homens e mulheres estes cujas raízes genéticas eram diferentes da população local.

O estudo de Costa-Junqueira et al. (1995) é de crucial importância para abordar o problema da influência do império Tiwanaku na sociedade atacamenha. Segundo ele, a influência do Império não se deu no nível biológico no sítio de Solcor-3, que foi ocupado antes e no auge da influência Tiwanaku. Ou seja, não houve imigrações do centro do Império para San Pedro de Atacama nesse período, pelo menos até onde esse sítio pode revelar. Os autores assumem a idéia de que a relação com Tiwanaku ocorreu no nível religioso e comercial, interpretando os objetos e os novos costumes praticados no deserto de Atacama apenas como assimilações de tradições estrangeiras pela população local.

Varela e Cocilovo (2000) realizaram o mesmo tipo de estudo utilizando onze variáveis métricas de 130 crânios oriundos dos sítios Quitor, Coyo Oriental, Larrache, Yaye e Tocanao Oriental. Os resultados apontam para uma direção diferente do trabalho anterior. Segundo tais autores, o período anterior à influência do Império Tiwanaku é caracterizado por uma marcada homogeneidade biológica, devida a um considerável isolamento populacional no Salar de Atacama. A partir do início da influência Tiwanaku (400 A.D.) ocorreu uma heterogenização biológica da população atacamenha, associada a uma maior taxa de imigração; a distância biológica entre os esqueletos desse período e o anterior é a maior entre os períodos analisados. A mudança na composição biológica da população a partir de 400 A.D. foi gradual, culminando em uma nova homogenização a partir de 1300 A.D.. Esses resultados suportam a visão de que a influência do Império Tiwanaku em San 
Pedro de Atacama foi não apenas de cunho religioso e comercial, mas também populacional $^{1}$. Dados de outras populações andinas serão cruciais para se obter um parâmetro comparativo, a fim de analisar a biologia local dentro de um contexto regional.

No que se refere aos estudos de estilo e qualidade de vida biológica foram realizadas análises de marcadores dentais (Neves e Costa, 1999; Neves et al., 2000; CostaJunqueira et al., 2004), traumas (Costa-Junqueira et al., 1998; Neves et al., 1999; CostaJunqueira et al., 2004; Torres-Rouf e Costa, 2006), estatura (Neves e Costa, 1998; CostaJunqueira et al., 2004), infecções (Glória et al., submetido) e hiperostose porótica (Neves e Costa, 1999; Costa-Junqueira et al., 2004). Desses estudos pode-se chegar às seguintes conclusões com respeito à influência do Império Tiwanaku em San Pedro de Atacama: 1) A tensão social (avaliada através de traumas cranianos) cresceu progressivamente do período anterior até o posterior à influência Tiwanaku, diminuindo drasticamente durante a ocupação Inca em San Pedro de Atacama. Já os acidentes cotidianos (avaliados através dos traumas no pós-crânio) permaneceram similares antes, durante e depois da influência do Império Tiwanaku; 2) A estatura média da população aumentou (principalmente a masculina), e o desgaste dentário e o número de cáries diminuíram durante a influência do Império Tiwanaku, indicando uma melhoria nutricional na população local, muito provavelmente relacionada com um maior consumo de proteína animal; 3) As infecções inespecíficas apresentaram a segunda maior incidência durante a influência de Tiwanaku, abaixo apenas do período posterior à Tiwanaku. O sítio Coyo-3 (final da influência Tiwanaku) apresentou os menores valores; 4) Hiperostose porótica não apresentou mudança significativa entre os períodos anterior, durante e posterior à influência do Império Tiwanaku; 5) As hipoplasias lineares do esmalte dentário apresentaram uma alta incidência no auge da influência do Império Tiwanaku e posterior à sua influência. Todos esses estudos tomaram como base apenas os esqueletos adultos.

Uma parte desses trabalhos apontou para uma melhoria da qualidade de vida biológica na sociedade atacameña durante a influência do Império Tiwanaku. Os marcadores cáries, estatura e desgaste dentário corroboraram tal hipótese. Porém, as

\footnotetext{
${ }^{1}$ Os autores desse artigo não mencionaram que o aumento de densidade demográfica em San Pedro de Atacama durante a influência do Império Tiwanaku pode ter gerado por si só mais diversidade populacional, evitando, assim, a necessidade do uso da migração como fator explicativo (Cavalli-Sforza et al., 1994).
} 
infecções, os traumas, as hipoplasias e a hiperostose porótica mostraram diferentes direções. A questão precisa, portanto, ser analisada mais a fundo, de forma independente.

Outro ponto importante na segunda categoria de estudos é a questão da deformação intencional do crânio. Podem-se identificar dois tipos de deformação em San Pedro de Atacama: tabular reta e tabular obliqua. O trabalho de Cocilovo et al. (1995) mostrou que é possível discriminar metricamente crânios deformados de crânios não deformados, ou seja, existe uma diferença real entre eles. As discussões sobre esse tema têm se concentrado sobre a importância das deformações como marcador de etnicidade e de status social. Llagostera et al. (1988) examinaram diferenças de deformação craniana entre os sexos, entre portadores e não portadores de tabletas e entre os dois períodos de Solcor-3 (préTiwanaku e sob a influência Tiwanaku). Llagostera (1996) também estudou a questão da influência Tiwanaku sobre a mudança do padrão de deformação craniana local. Os homens passaram a privilegiar a deformação tabular reta, ao invés de apresentar ambas as formas (obliqua [Figura 8] e reta). Portanto, parece ter havido uma seleção mais rigorosa do tipo de deformação craniana pelos homens durante a influência do império. Ao mesmo tempo, as mulheres apresentaram um aumento das deformações cranianas, porém sem uma preferência por um dos diversos tipos. Esses dois artigos apóiam o uso da deformação do crânio como sinal de status social.

Por fim, cabe destacar o estudo de Costa-Junqueira e Neves (1990) sobre a organização social no período dos señorios (posterior à influência do Império Tiwanaku). Utilizando estatística multivariada de ponta já no início dos anos 1990, esses autores buscaram correlacionar diversos marcadores de qualidade de vida com status social (inferido pelos acompanhamentos funerários). Não encontraram associação significativa entre esses dois elementos. Tal conclusão é importante uma vez que questiona as interpretações arqueológicas que sugerem hierarquização nesse período. Segundo CostaJunqueira e Neves (1990), se realmente havia líderes com alto status, eles não adotavam nem um repertório nutricional nem um elenco de atividades cotidianas diferenciadas do restante da população. 

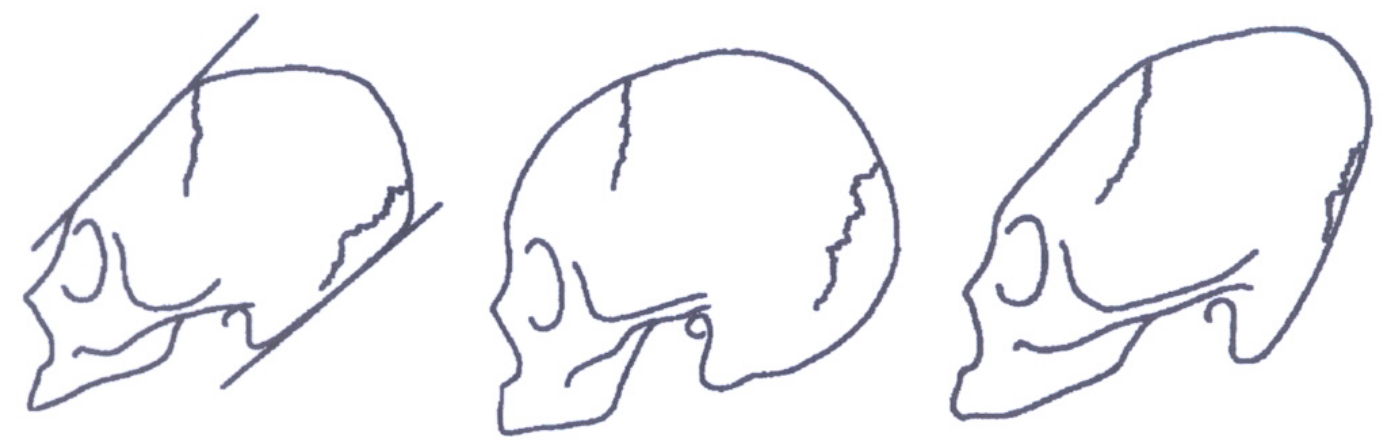

Figura 8 - Tipologia das deformações cranianas intencionais. À esquerda a deformação tabular obliqua, à direita a deformação anular e no centro um crânio não deformado (adaptado de Blom, 2005).

\section{3 - Os sítios estudados}

Foram estudados três sítios arqueológicos que apresentaram esqueletos humanos de subadultos. Eles serão descritos a seguir.

O sítio Solcor-3 localiza-se no Salar de Atacama próximo ao rio San Pedro. As datações realizadas no sítio indicaram dois períodos diferentes de ocupação: a fase A e a fase B. A fase A é caracterizada pela cerâmica negra polida e pelo início da inclusão de tabletas como acompanhamento funerário; devido à escassez da iconografia Tiwanaku na cultura material, o período é conhecido como pré-Tiwanaku. A fase B é caracterizada pela cerâmica cinza grossa polida com semelhanças com o negro polido e pela presença de tabletas com iconografia Tiwanaku nos acompanhamentos funerários; a fase é conhecida como o período de influência máxima de Tiwanaku em San Pedro de Atacama (Llagostera et al., 1988).

O sítio apresenta uma ótima preservação de madeira, cestaria e esqueletos, o que o tornou central nas inferências sobre a sociedade atacamenha. Muitos conjuntos psicotrópicos foram ali encontrados; em geral, eles são formados por uma tableta, uma colherinha, um tubo de inalação e uma ou duas bolsas de couro com substâncias alucinógenas, todas dentro de uma bolsa têxtil (Figura 9). A presença desses complexos alucinógenos nos enterramentos da Fase A não implicou que os acompanhamentos 


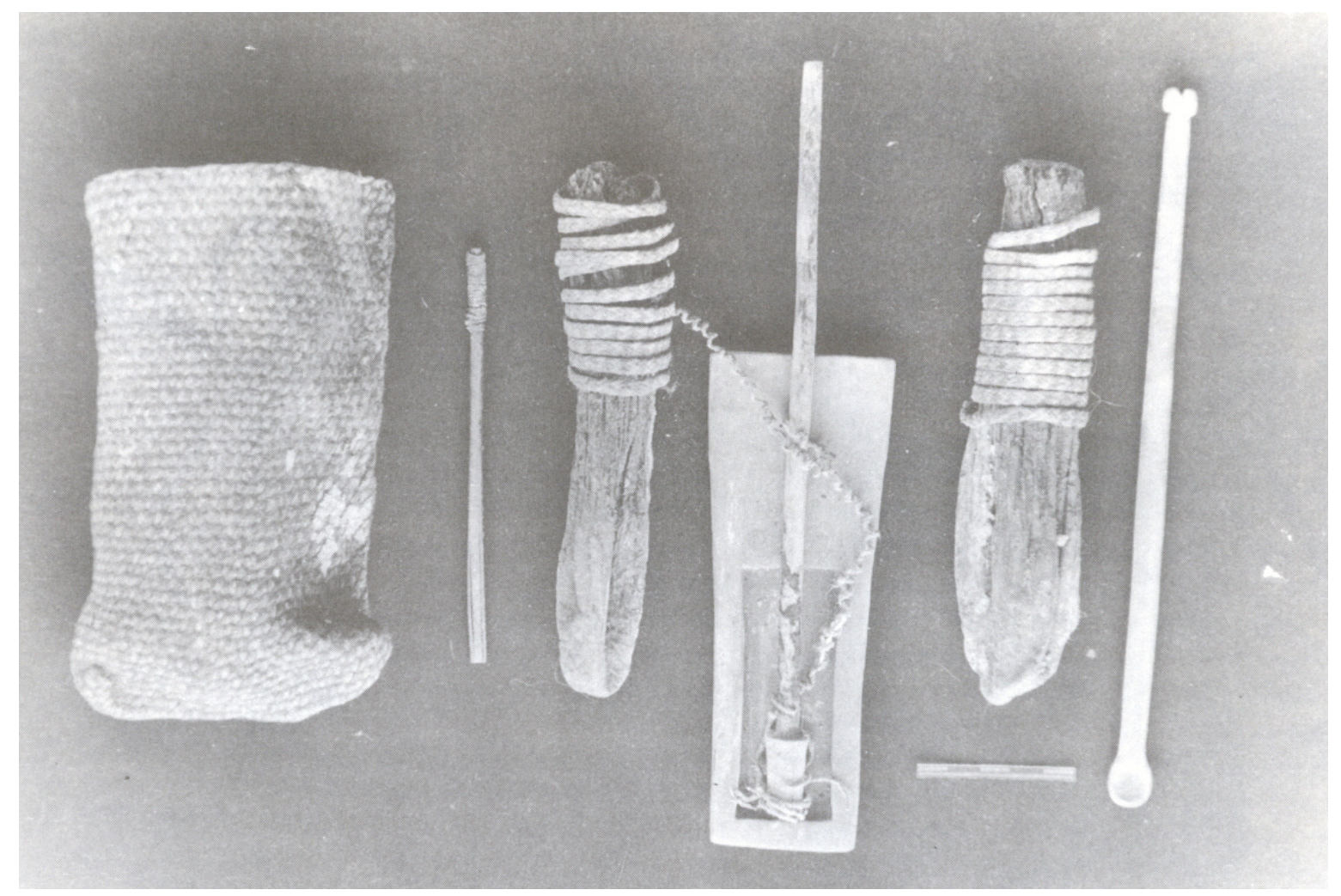

Figura 9 - Constituintes do complexo alucinógeno encontrado associado a um enterramento do sítio Solcor-3 (adaptado de Llagostera et al., 1988).

funerários de seus respectivos indivíduos fossem mais elaborados que os acompanhamentos funerários dos indivíduos enterrados sem tableta. Já na Fase B, os enterramentos com tableta associada apresentavam mais acompanhamentos funerários que os enterramentos sem tableta, além de apresentarem mais objetos exógenos. Solcor-3, portanto, é um sítio chave para a sustentação da conexão simbólica e religiosa de Tiwanaku com San Pedro de Atacama, fornecendo subsídios para consolidar a idéia de estratificação social durante a influência altiplânica. Os indivíduos de maior status em Atacama, segundo essa linha de pensamento, estavam relacionados com o comércio inter regional e com as atividades religiosas. O índice de tiwanakização (porcentagem de enterramentos com tableta) de 32 \% em Solcor-3 é um dos maiores da região de San Pedro de Atacama, mostrando a forte influência exercida por Tiwanaku nesse sítio (Llagostera et al., 1988). 
A discussão sobre a composição da substância alucinógena é outro ponto para o qual o sítio Solcor-3 contribuiu decisivamente. A identificação dos componentes químicos da substância encontrada dentro das bolsas de couro dos kits de inalação apontou para a planta do gênero Anadenanthera (Torres et al., 1991). Essa descoberta é importante na medida que se conhece a distribuição atual dessa planta: sua freqüência é muito baixa em florestas tropicais como as da Amazônia. Tal dado vem em oposição à teoria vigente de que a Amazônia seria o centro dispersor do complexo alucinógeno. A dispersão do complexo alucinógeno nos Andes meridionais passou então a ser encarada como um fenômeno de sul para norte, e não o inverso, como se acreditava. Além disso, existem evidências arqueológicas que apontam para o uso de alucinógeno nos Andes desde 1200 a.C., enquanto que na Amazônia as evidências arqueológicas são muito escassas (Torres et al., 1991). Torres et al. (1991) especularam que na Amazônia utilizava-se outra substância alucinógena, retirada da casca de árvores do gênero Virola.

As plantas do gênero Anadenanthera não são encontradas no norte do Chile, mas sim, no noroeste argentino (Figura 10). Esse dado mostra a importância do tráfico de sementes alucinógenas entre essas duas regiões. No que tange à tradição de tabletas para a inalação de alucinógenos, o intercâmbio parece ter inexistido entre essas regiões, já que a ocorrência de tabletas no noroeste argentino iniciaram-se a partir de 1000 A.D. e em San Pedro de Atacama ela terminou por volta desta data. O intercâmbio de tabletas em San Pedro de Atacama parece ter sido feito, prioritariamente, com o Império Tiwanaku (Figura 11) (Torres, 1999).

O segundo sítio analisado neste trabalho é o de Coyo-3; este se insere no final da influência do Império Tiwanaku (910 a 960 A.D.). As condições de preservação desse sítio não eram muito boas. A composição arenosa do solo e o grande número de raízes impediram que materiais perecíveis como madeira e tecido fossem preservados. A importância desse sítio para a compreensão da pré-história de San Pedro de Atacama advém do estabelecimento de uma setorização no cemitério escavado. Os enterramentos foram divididos pelos pesquisadores em dois grupos: A e B (Costa-Junqueira e Llagostera, 1994). O primeiro deles ocupa o setor sul do cemitério e apresenta uma associação funerária quantitativamente e qualitativamente inferior em relação ao Grupo B. Já o segundo grupo ocupa o setor norte do cemitério e apresenta, exclusivamente, uma 


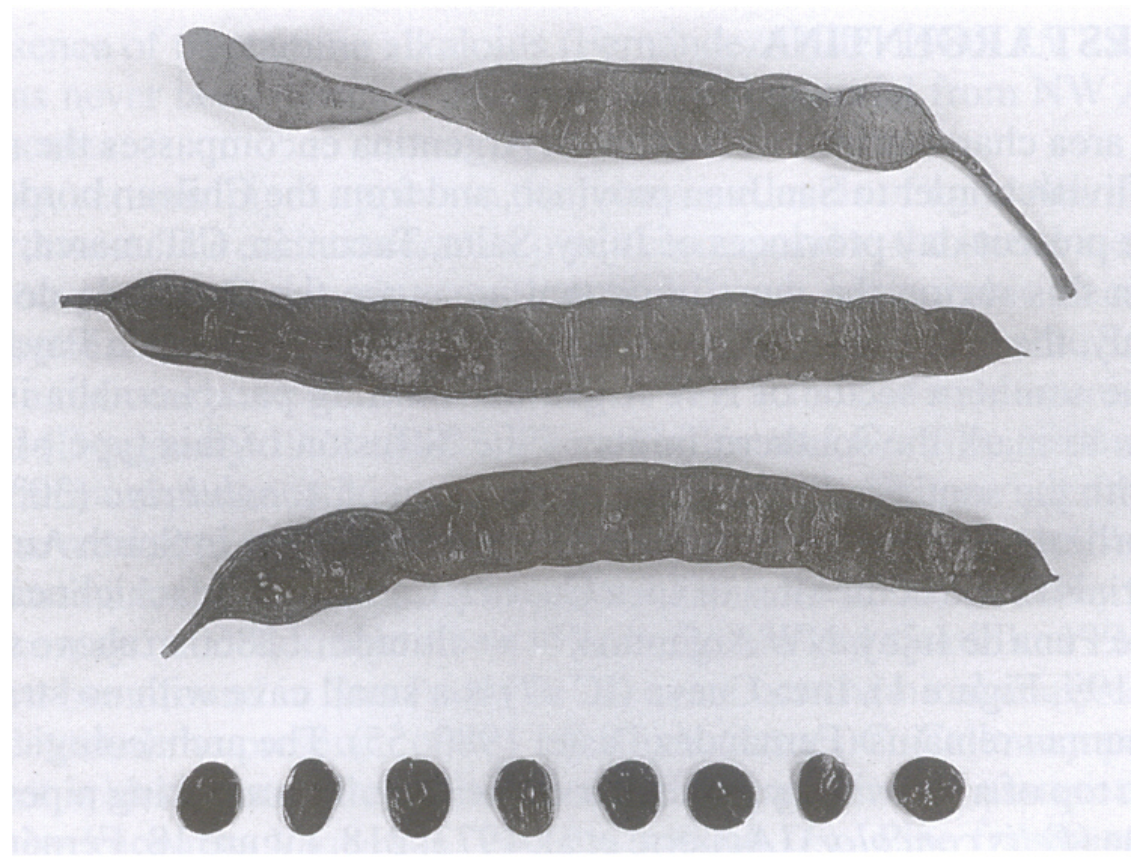

Figura 10 - Sementes e vagens de Anadenanthera colubrina da província de Salta, Argentina (adaptado de Torres, 1999).

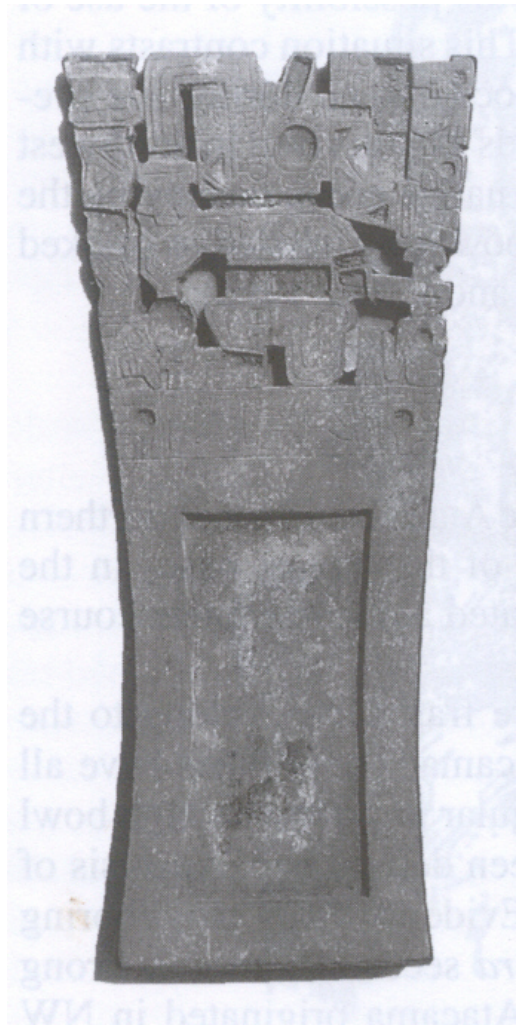

Figura 11 - Tableta para inalar alucinógenos do sítio Solcor-3 apresentando típica decoração Tiwanaku típica (adaptado de Torres, 1999). 
associação funerária composta por tabletas para alucinógenos e metais. O Grupo B é o único, também, que apresenta camelídeos enterrados como oferenda funerária. Tal divisão sugere a existência de duas classes com poderes assimétricos, no que se refere ao status e ao domínio da esfera religiosa. Utilizando analogia etnohistórica, os autores sugeriram que essa divisão representava duas metades assimétricas formais. Esse tipo de divisão social é bem conhecido nas populações andinas atuais e passadas, como por exemplo, entre os Lupaqa da região do lago Titicaca. Ambas as classes em Coyo-3 parecem ter convivido em um mesmo espaço, descartando a possibilidade de segregação social entre elas (CostaJunqueira e Llagostera, 1994). Os esqueletos subadultos de Coyo-3 estavam relacionados a esses dois grupos: 5 perteciam à classe A, 7 à classe B e 6 não tinham filiação definida. As duas classes não apresentaram diferenças quanto à presença de marcadores osteológicos nos esqueletos subadultos, razão pela qual foram tratados conjuntamente neste trabalho. A distinção arqueológica das duas classes parece não ter qualquer relação com os indicadores de estilo e qualidade de vida biológica nos subadultos.

O sítio Quitor-6 insere-se na fase posterior à influência do Império Tiwanaku (940 a 1240 A.D.). Trata-se de um cemitério, cujos acompanhamentos funerários apresentam três características importantes: 1) poucos objetos por indivíduo; 2) os objetos, em sua maioria, apresentam miniaturização; e 3) empobrecimento da técnica de confecção e ausência quase completa de decoração. Os objetos encontrados são cerâmica Dupont e Roja Violácea, cabaças, cestas, objetos de madeira (colheres, pilões, tableta, kero, espátula, caixinhas, torteras, arcos, agulhas), têxteis, metais e líticos (Costa-Junqueira, 1988).

O sítio não apresentou qualquer divisão espacial dos enterramentos, o que fez com que Maria Antonietta Costa-Junqueira interpretasse esse fato como um indicativo de uma sociedade igualitária, assumindo que os indivíduos de maior status não estariam enterrados em outro cemitério. A relevância desse sítio para a compreensão da pré-história atacamenha é a significativa queda no nível de elaboração e na quantidade da cultura material. Esses dados sustentam a hipótese de que após a influência do Império Tiwanaku ocorreu uma queda abrupta no desenvolvimento da cultura material em San Pedro de Atacama (pelo menos no que se refere aos acompanhamentos funerários) (Costa-Junqueira, 1988). 
Em síntese, tanto arqueologicamente como antropologicamente, há indícios de que, de fato, a influência do Império Tiwanaku em San Pedro de Atacama melhorou o nível econômico da população atacamenha em relação aos períodos pré e pós Tiwanaku. 


\section{Capítulo 3 - Marcadores Osteológicos}

\section{1 - Hiperostose porótica}

Hiperostose porótica é uma condição patológica que se caracteriza pela expansão dos ossos do crânio, formando pequenos orifícios na superfície externa do osso. Microscopicamente, os espaços entre as trabéculas são aumentados e se abrem na superfície exterior do osso. Ocorre também um aumento de espessura na região medular do osso. As regiões mais atingidas são os ossos occipital, frontal e parietal, bem como a superfície superior da órbita (cribra orbitalia) (Stuart-Macadam, 1992), tanto no crânio de humanos como na órbita de primatas não humanos (Nathan e Hass, 1966). A relação entre as lesões na órbita e na calota craniana é de grau; as marcas na órbita aparecem em situações de estresse mais brando (Stuart-Macadam, 1989). Sabe-se, portanto, que apesar de variações no local de ocorrência da hiperostose porótica, estas lesões são manifestações de uma mesma etiologia (Holland e O’Brien, 1997; Larsen, 1997; Goodman e Martin, 2002). As evidências nesse sentido vem de dados macroscópicos, clínicos, radiográficos e microscópicos (Stuart-Macadam, 1987; ver porém Wapler et al., 2004).

A hiperostose porótica é aceita como uma lesão causada pela anemia ferro-priva (Stuart-Macadam, 1987). Apesar do consenso, as razões da baixa disponibilidade de ferro no organismo são ainda bastante debatidas. As primeiras idéias sobre as causas da anemia relacionavam-se a fatores genéticos ligados à talassemia. Estes estudos foram feitos na Europa e na África, onde a anemia falciforme confere uma proteção contra o ataque do Plasmodium falciparum, causador da malária. A heterozigose do gene que expressa a hemoglobina foi favorecida pela seleção natural nessas regiões; no entanto pode provocar efeitos negativos como a anemia (Angel, 1966; Huss-Ashmore et al., 1982; Inhorn e Brown, 1990). Entretanto, a hiperostose porótica com causa genética não explica a ampla distribuição da lesão (inclusive na Australia e na América), nem mesmo a alta frequência encontrada nas populações dos últimos dez mil anos (Larsen, 1997; Goodman e Martin, 2002).

O primeiro grande modelo para explicar a causa da deficiência de ferro não relacionado à genética foi proposto por Carlson et al. (1974) e El-Najjar et al. (1976). 
Conhecida como a hipótese da dependência do milho, baseia-se na baixa quantidade de ferro presente neste vegetal. Além da baixa disponibilidade, os cereais têm ácido fítico que possui um efeito quelante, que diminui a absorção do ferro pelo intestino (Holland e O’Brien, 1997).

Uma série de estudos subsequentes desenvolveu a ligação entre alimentação e disponibilidade de ferro. Porém, apesar dos progressos realizados, ficou evidente que a dieta não é o único fator envolvido (Kent, 1986; Walker, 1986; Stuart-Macadam e Kent, 1992). Uma intrincada rede de fatores como qualidade da água, higiene, infecções, diarréia, parasitismo, acesso a recursos, formas de preparo da comida, tempo de amamentação, entre outros, podem influir na quantidade de ferro disponível no organismo (Holland e O’Brien, 1997; Goodman e Martin, 2002).

A maior incidência de hiperostose porótica ocorre nos primeiros anos de vida, devido ao pequeno tamanho do espaço medular em ossos de criança. O tecido hematopoeiético ocupa a totalidade da medula no nascimento; a partir dos quatro anos começa a ser substituído por gordura, e por volta dos 12 aos 14 anos este processo já é bem evidente (Stuart-Macadam, 1985). Os estudos clínicos apontam nessa mesma direção. As crianças possuem reservas de ferro até os seis meses de idade, após esse período necessitam de ferro na alimentação. As infecções e o estresse alimentar devido ao desmame são comuns nessa idade, tornando-as o principal alvo da anemia (Ryan, 1997). As mulheres também apresentam uma alta incidência de anemia, que é relacionada aos altos custos da gestação e da menstruação (Holland e O’Brien, 1997).

Por fim, Wapler et al. (2004) introduziram mais um complicador neste marcador: mais da metade dos casos de cribra orbitalia analisados por eles, histologicamente, não são causados por anemia, mas sim por infecções, quando não por razões apenas tafonômicas. $\mathrm{O}$ consenso em torno da anemia foi colocado em questão; resta saber até que ponto as conclusões daqueles autores poderão ser generalizadas para outras populações do mundo. Sullivan (2005), por outro lado, pondera que é extremamente prematuro abandonar a etiologia clássica desse marcador, uma vez que há uma concordância entre cribra orbitalia e dados radiográficos, clínicos, etnográficos e paleopatológicos de anemia. 


\section{2 - Hipoplasia linear do esmalte dentário}

A hipoplasia é o resultado de uma parada na produção de esmalte pelos ameloblastos durante a formação da coroa dentária. Macroscopicamente, é possível visualizar uma falha na estrutura externa do esmalte (Goodman e Rose, 1990). No presente estudo foram consideradas apenas as falhas que possuem disposição linear.

As hipoplasias causadas por fatores genéticos são raras, ocorrendo com frequências que giram ao redor de 1/14000 e 1/1000, conforme a população analisada. A grande maioria dos casos de hipoplasia está relacionada a estresses fisiológicos ocorridos durante a formação do dente. Estes distúrbios podem estar relacionados a problemas sistêmicos ou locais (Hillson, 1996).

Diversos estudos buscaram relacionar episódios de doença com a ocorrência de hipoplasias, porém esta relação não é tão nítida quanto esperada. Até mesmo em amostras com descrições médicas detalhadas do histórico de doenças dos pacientes, não foi possível estabelecer uma conexão clara entre efermidades e hipoplasias em cerca de cinquenta porcento dos casos (Goodman e Rose, 1990; Hillson, 1996). Ao invés de um marcador específico para determinadas doenças, a hipoplasia é entendida hoje como o resultado de uma rede intrincada de fatores infecciosos, nutricionais e genéticos que afetam a fisiologia do indivíduo, alterando as taxas de produção de esmalte pelos ameloblastos (Goodman e Rose, 1990; Goodman e Martin, 2002).

A susceptibilidade diferencial dos dentes humanos é fundamental para entender o padrão de distribuição das hipoplasias. Os incisivos centrais superiores, os caninos inferiores e o segundo terço da coroa dos dentes permanentes são mais susceptíveis às hipoplasias. Isto se deve à estrutura de formação da peça dental, cujos fatores genéticos e desenvolvimentais ainda são mal compreendidos (Goodman e Rose, 1990; Hillson, 1996). Sabe-se, no entanto, que cada tipo de dente apresenta uma estrutura superficial do esmalte diferente. O tipo de perikimata nos molares, por exemplo, é constituído por mais sulcos espaçados do que nos incisivos, que apresentam mais sulcos pronunciados e próximos. Da mesma forma, os molares apresentam uma maior zona aposicional (esmalte que não fica exposto na superfície do dente) do que os incisivos, influindo na área de visualização das hipoplasias (Hillson e Bond, 1997). 
Ciente de que a hipoplasia é um marcador de estresse não específico, ela é utilizada como um importante indicador de mudanças nos padrões de subsistência. O aumento da frequência de hipoplasias está associado à transição entre caçadores-coletores e agricultores (Hutchinson e Larsen, 1988; Larsen, 1997; Cucina, 2002), ao contato entre nativos e europeus na América (Larsen, 1997; Santos e Coimbra Jr., 1999), à nutrição em países subdesenvolvidos (Goodman et al., 1987; Goodman e Rose, 1990; Larsen, 1997), e ao início da industrialização (Wood, 1996).

Um estudo bastante proeminente com o uso de hipoplasias é a definição do período de desmame. Nesses trabalhos é usada a propriedade do esmalte dentário de registrar a cronologia do estresse fisiológico na infância (Reid e Dean, 2000). Apesar de constituir uma propriedade de grande valor para a antropologia, há muitas críticas a este raciocínio (ver Hillson, 1996; Katzenberg et al., 1996). Além dos problemas metodológicos de acesso à cronologia dos estresses, é difícil precisar o momento de ocorrência do desmame pelo uso das hipoplasias, devido à multiplicidade de fatores que causam estresse na criança (Blakey et al., 1994; Katzenberg et al., 1996; Wood, 1996). Esta abordagem pode ser denominada de "história do desenvolvimento" em oposição à comparação entre freqüências de hipoplasias entre populações, denominada de "história macrotemporal” (Santos e Coimbra Jr., 1999). Somente a última análise foi realizada neste trabalho.

\section{3 - Cárie}

A cárie é a destruição do esmalte dentário, dentina ou cemento resultante da produção de ácido pelas bactérias em uma placa dental. A desmineralização do esmalte ocorre quando o $\mathrm{PH}$ da boca fica mais ácido do que 5,5. As bactérias Lactobacillus acidophilus e Streptococus mutans são as principais responsáveis pela acidificação do meio, pois elas metabolizam grande quantidade de carboidratos e o ácido resultante ataca os dentes (Hillson, 1996).

Existe uma correlação positiva entre quantidade de açúcar consumido e quantidade de cáries. Os açucares simples (sucrose, principalmente) são os mais relacionados com as cáries, pois sua metabolização pelas bactérias é feita com muita eficiência. Os carboidratos complexos (amido, por exemplo) são menos cariogênicos, já que sua quebra é mais 
demorada e, portanto, não ocasionam PHs tão baixos na boca (Hillson, 1996; TougerDecker \& Loveren, 2003). O tempo de exposição do carboidrato na cavidade oral e a frequência de consumo são fatores cruciais para o desenvolvimento das cáries. Quanto mais tempo o carboidrato permanece na boca, maior o tempo que o substrato está disponível para o metabolismo das bactérias (balas e pirulitos, por exemplo, são muito cariogênicos). Carboidratos que são facilmente limpos pela saliva e pela língua são menos cariogênicos (chocolate e banana, por exemplo). Alimentos ingeridos a altas temperaturas aceleram a ação da amilase e tendem a provocar mais cáries (batata frita, por exemplo) (TougerDecker e Loveren, 2003).

A cárie é um marcador dental com causa multifatorial. Existe um sinergismo entre saúde bucal e nutrição, no qual o primeiro tem um efeito sobre a limpeza e a manutenção do PH da boca e o segundo tem um efeito sobre os componentes minerais e orgânicos que regulam o metabolismo bacteriano. O fluxo salivar possui papel crucial na limpeza dos resíduos de carboidratos; desta forma, os fatores genéticos e nutricionais que afetam a composição e o volume da saliva alteram a freqüência de cáries. O consumo de alimentos ricos em cálcio, caseína e fosfatos (queijos e proteínas) aumentam a produção de saliva e inibem a placa bacteriana, já que apresentam substâncias alcalinas. O consumo de alimentos com polifenóis (cacau, café, chá) e poliols (chiclete sem açúcar) inibem o metabolismo de bactérias e estimulam a salivação. Atualmente, a escovação e a água fluoretada diminuíram sensivelmente o índice de cáries, mascarando a correlação entre cáries e açucares (Touger-Decker e Loveren, 2003).

Estudos bioarqueológicos destacam o aumento da freqüência de cáries com a mudança da caça e coleta para a agricultura. O consumo de milho, tâmara, trigo, taro ou painço por diversas populações agricultoras ao redor do mundo aumentou sensivelmente a quantidade de carboidratos na dieta, causando aumentos de até dez vezes na freqüência de cáries (Turner II, 1979; Larsen, 1983, 1997; Nelson et al., 1999; Goodman e Martin, 2002). Exceções a esse quadro geral existem, como por exemplo, o intercâmbio de alimento entre grupos agricultores e caçadores-coletores, e o consumo de plantas altamente cariogênicas por não agricultores (Larsen, 1997). Outros temas também relevantes na literatura são os estudos sobre a intensificação da agricultura (Hodges, 1987; Schollmeyer e Turner II, 
2004), a diferenciação sexual (Larsen, 1983; Lukacs, 1996), o status social (Cucina e Tiesler, 2003) e o consumo de açúcar (Saunders et al., 1997).

Estudos relacionando taxa de desgaste dentário e cáries indicam uma correlação negativa entre estes marcadores (Maat e Van der Velde, 1987). A explicação para esta constatação é que o desgaste dentário elimina as cáries que estariam sendo formadas na face oclusal do dente, além de dificultar a formação da placa bacteriana, cuja aderência no esmalte acontece com muito mais facilidade nas cúspides e nas fendas da face oclusal (Larsen, 1997). Exceção a este modelo pode ser encontrada na população pré-histórica do mesolítico português, na qual a alimentação baseada em figos causou alto desgaste e alto índice de cáries (Meiklejohn et al., 1992).

\section{4 - Abcesso}

O abcesso de origem odontogênica é uma inflamação na qual há acúmulo de pus e desintegração de tecido. A localização da infecção pode ser tanto na região periodontal (gengiva) como na raiz do dente (periapical). A inflamação bacteriana inicia-se na região pulpar do dente (pulpite) ou no interior da gengiva (Clarke, 1990; Dahlén, 2002). A causa desta lesão são as toxinas de bactérias, que estimulam a reação imunológica do organismo e desencadeiam uma inflamação local. A partir do momento que a inflamação cresce mais do que o espaço alveolar ou periodontal, forma-se um canal de drenagem (fístula) para expulsar o pus acumulado, caracterizando a fase aguda do abcesso (Buikstra e Ubelaker, 1994; Hillson, 1996). A infecção pode durar anos (fase crônica) até o desenvolvimento da fase aguda. A formação do canal de drenagem causa grandes lesões no osso da mandíbula e do maxilar; e são estas marcas que diagnosticam o abcesso encontrado em esqueletos de

origem arqueológica. $\mathrm{Na}$ análise de esqueletos, o termo abcesso é usado para as inflamações de origem periapical (pulpal) e o termo lesão periodontal é usado para inflamações de origem gengival (Hillson, 1996). No presente trabalho, foi usado o marcador abcesso (origem pulpal).

Uma série de bactérias está envolvida na formação de abcessos. A infecção é caracterizada por bactérias anaeróbicas de diferentes gêneros e constituições de parede 
(gram-negativa e gram-positiva); a maioria das bactérias responsáveis pela infecção é residente da flora oral do indivíduo afetado (Dahlén, 2002).

O sistema imunológico é um fator crucial no desenvolvimento do abcesso. Um sistema imune forte não evita a ocorrência de uma infecção, mas acelera o processo de cicatrização, evitando o desenvolvimento da fase crônica e aguda. Este fator sistêmico relaciona-se com a homeostase entre o indivíduo e as bactérias residentes da flora oral (Dahlén, 2002). Os fatores que podem aumentar a ocorrência de abcessos são: excesso de

desgaste dentário (exposição da pulpa), cáries, fraturas do esmalte dentário, trauma local, má oclusão e baixa higiene oral (Scott e Turner II, 1988; Buikstra e Ubelaker, 1994; Larsen, 1997). Estes fatores estão diretamente relacionados aos abcessos porque provocam lesões na gengiva e facilitam o acesso das bactérias (e suas toxinas) à pulpa e à raiz do dente.

\section{5 - Desgaste dentário}

O desgaste dentário é resultado de dois processos básicos: abrasão, que é o contato entre o dente e as partículas do alimento; e atrito, que é o contato de um dente com outro. Ambos os processos ocorrem simultaneamente na mastigação (Hillson, 1996; Larsen, 1997). O grau de desgaste dentário é uma soma destes dois processos, refletindo diretamente o tipo de alimentação que uma população consome.

Existem três sistemas principais de medição: o de Molnar (1971), o de Scott (1979) e o de Smith (1984). Neste estudo foi utilizado o sistema de Molnar (1971), cujo desgaste é divido em oito graus, sendo o grau 1 o de menor desgaste (recém erupcionado).

Os estudos sobre alimentação de populações pré-históricas têm enfatizado a diferença entre agricultores e caçadores-coletores. A alimentação baseada em produtos processados (cozidos, moídos, em forma de pasta) diminui sensivelmente o desgaste dentário. Este tipo de alimento é comum em agricultores. Porém, é importante observar que ao processar o alimento com instrumentos de pedra, as partículas resultantes aumentam a abrasão no dente, causando maior desgaste. Desta forma, apesar de existir uma tendência para agricultores apresentarem um menor desgaste que caçadores-coletores, a presença de partículas na comida e a consistência do alimento acaba sendo tão importante como o modo 
de subsistência da população (Larsen, 1997). A angulação do desgaste é diferente entre agricultores e caçadores-coletores. Os primeiros apresentam angulação acentuada com formato côncavo enquanto os segundos têm desgaste plano (Smith, 1984); exceções a esta regra existem (Lubell et al., 1994).

Uma importante linha de estudo do desgaste dentário é a diferenciação funcional entre dentição anterior e dentição posterior. A primeira tem o papel de fazer a preparação inicial e cortar o alimento, enquanto a segunda realiza a redução da comida. Desta forma, diferentes subsistências utilizam diferentemente estas regiões. Caçadores-coletores apresentam maior desgaste absoluto e relativo na dentição anterior comparados aos agricultores. Isso pode ser explicado tanto pelo uso extra-mastigatório da dentição anterior, como pela necessidade de cortar o alimento com os dentes, já que, ao contário da agricultura, não há formas de preparação pré-oral do alimento (cozimento, por exemplo) que realizem esta tarefa (Hinton, 1981; Kaifu, 1999).

\section{6 - Infecção inespecífica}

As infecções não específicas podem agir no periósteo ou na cavidade medular, causando diferentes níveis de lesões. A periostite possui menor gravidade, pois se limita à região superficial do osso; já a osteomielite é mais perigosa, pois pode facilmente se espalhar pelo corpo através da circulação. A primeira lesão é a mais frequente em esqueletos de origem arqueológica. As bactérias relacionadas com estas lesões em populações vivas são Staphylococcus aureus (80-90\% dos casos), Escherichia coli, Salmonella typhi e Neisseria gonorrhoeae. Traumas podem ser portas de entrada para estas infecções (Larsen, 1997). Neste estudo não foi feito diagnóstico diferencial dessas patologias. Portanto, as infecções não específicas aqui apresentadas podem incluir uma ampla gama de etiologias.

Apesar da inespecificidade dessas categorias de infecções, elas apresentam um grande valor em uma abordagem paleoepidemiológica (Souza, 1999). Os estudos usando este marcador enfatizam o aumento da incidência de infecções na transição de uma população de alta mobilidade para uma população sedentária, relacionando esta passagem com a agricultura e a domesticação de animais. A velocidade de transição entre esses 
modos de subsistência também é um fator importante, pois quanto mais brusca é a mudança pior é o efeito na saúde dos indivíduos (Hodges, 1987). A agregação e o sedentarismo estão relacionados a uma maior proximidade entre as pessoas, facilitando uma cadeia de contágio infeccioso. O aumento populacional, ligado a estes eventos de agregação, facilita a permanência dos patógenos através de epidemias mais agudas, cuja ocorrência entre caçadores coletores é limitada pelo pequeno número de pessoas e pela distância entre os grupos locais. Observa-se, portanto, que populações nômades possuem maior incidência de patógenos de baixa transmissão em detrimento de epidemias com ação aguda (Cockburn, 1971; Kent, 1986; Inhorn e Brown, 1990; Larsen, 1997). A agregação na ausência de agricultura (populações pescadoras, por exemplo) é suficiente, em alguns casos, para explicar o aumento da quantidade de infecções, sem recorrer a explicações dietéticas (Lambert, 1993).

A domesticação de animais é outra fonte de doenças, já que muitos patógenos utilizam os animais como hospedeiros secundários. O sedentarismo está relacionado com o aumento da produção e acúmulo de lixo, diminuindo as condições de higiene e aumentando as infecções. A circulação de pessoas é um fator importante na incidência de infecções já que traz patógenos de regiões distantes, para os quais a população local não possui resistência. Exemplo clássico dessa transmissão é a colonização da América pelos europeus, provocando epidemias devastadoras na população local (Cockburn, 1971; Inhorn e Brown, 1990; Larsen, 1997).

O sinergismo entre infecção e alimentação é de suma importância para a interpretação deste marcador. A deficiência nutricional debilita o sistema imunológico do indivíduo, aumentando sua chance de contrair uma infecção. Ao mesmo tempo, como um alto índice de patógenos consome muita energia do indivíduo, isso pode provocar problemas nutricionais. Os aspectos nutricionais e infecciosos possuem certa independência, mas, inevitavelmente, acabam por influenciar-se mutuamente (Inhorn e Brown, 1990, Larsen, 1997).

\section{7 - Trauma}


Os traumas são, sobretudo as fraturas, um marcador valioso na reconstituição de dois aspectos do comportamento pretérito: acidentes cotidianos e tensão social (violência interpessoal e intergrupal). Existem diversos protocolos de classificação de fraturas que visam a elucidar qual o tipo de objeto que causou o impacto. O objeto pode ser cortante ou contundente, pode causar fraturas abertas ou fechadas (referente ao rompimento da pele); o trauma pode ser direto ou indireto; pode causar fratura ou deslocamento, pode ser por impacto ou por estresse, entre muitas outras classificações (Lovell, 1997). Uma vez com esses dados é possível especular as razões sociais e ambientais dos traumas na população (Larsen, 1997).

A cicatrização é um aspecto importante na avaliação da conseqüência do trauma. Fraturas que tenham ocorrido até duas ou três semanas antes da morte do indivíduo não deixam marcas de cicatrização (calo ósseo). Este tipo de fratura é conhecido como perimorten, e está vinculado com o período imediatamente posterior ou anterior à morte do indivíduo. Por outro lado, fraturas cicatrizadas podem revelar sinais de tratamento e imobilização das lesões em sociedades pretéritas. A ausência desse tipo de cuidado pode dar origem a infecções, rompimento de nervos, atrofia muscular, perda de articulação e deformação óssea (Lovell, 1997).

A quantidade de estudos que analisam traumas em séries esqueletais é bastante grande. Os que abordam fraturas decorrentes do estilo de vida associam um maior número de ocorrências a caçadores-coletores do que a agricultores. A rotina de forrageio aumenta as chances de fratura, como pode ser constatada no caso dos neandertais de Shanidar (Berger e Trinkaus, 1995). Mulheres idosas tendem a ter mais traumas devido à osteoporose, assim como os homens jovens devido às guerras (Larsen, 1997). As particularidades da topografia do terreno e do tipo de atividade cotidiana na sociedade em questão são cruciais para se entender a quantidade de fraturas (Burrel et al., 1986).

A guerra é outra vertente dos estudos deste marcador osteológico. Vista como um fenômeno universal nas sociedades humanas (Ember e Ember, 1998; Lekson, 2002), as guerras deixam marcas em esqueletos de qualquer população. Exemplo são as populações pré-históricas dos Estados Unidos (Lovejoy e Heiple, 1981; Milner et al., 1991; Smith, 2003), os Inuit (Melbye e Fairgrive, 1994), os povos pré-históricos da América do Sul (Standen e Arriaza, 2000), norte da Europa, Polinésia e os forrageadores australianos 
(Larsen, 1997). As guerras deixam marcas diversas pelo corpo (decaptação, escalpelamento, fraturas no crânio e no pós-crânio) dependendo do tipo de conflito envolvido. Existe uma relação entre traumas no crânio e violência interpessoal, não necessariamente em um contexto de guerra. A incidência e o tipo de lesão no crânio podem ser um indicativo do grau de conflito interno em uma sociedade e do tipo de tecnologia predominante naquele período (Larsen, 1997).

\section{8 - Estatura}

A estatura final de um indivíduo depende tanto de fatores genéticos como ambientais. O fator genético é bastante importante, mas o indivíduo só atingirá todo o seu potencial biológico se ele usufruir de condições adequadas de vida (Bogin, 1988; Steckel, 1995). A estatura é conhecida como um marcador inespecífico de estresse, porque uma série de fatores pode ser a causa da diminuição do crescimento. Baixa nutrição e alta taxa de infecções, por exemplo, impedem que o potencial genético seja atingido (Larsen, 1997).

Estatura é um bom marcador de diferenças entre classes sociais. O acesso diferencial a recursos médicos e alimentação pode ser inferido a partir das diferenças de estatura (Tanner, 1986). A transição da caça e coleta para a agricultura provocou mudanças na estatura. Populações agricultoras de todo o mundo apresentam uma redução na estatura final de seus indivíduos em comparação com caçadores-coletores. Problemas nutricionais são aventados como os principais motivos para essa redução (Larsen, 1997).

O estudo da estatura em subadultos é bastante importante, pois é possível observar eventos de estresse agudo ao longo do crescimento ósseo. A estatura de um adulto pode mascarar esses eventos agudos uma vez que o esqueleto pode recuperar o comprimento dos ossos depois do estresse. Tal fenômeno é conhecido como “catch up”. A estatura final, portanto, estaria mais ligada a estresse crônico do que a agudo. Já nos subadultos é possível visualizar eventos agudos, desde que se consiga traçar a variação da estatura nas diversas faixas etárias de crescimento ósseo (Goodman e Martin, 2002). 


\section{Capítulo 4 - Comparação entre os períodos}

\section{1 - Material e métodos}

A amostra utilizada neste trabalho consiste de 90 esqueletos subadultos (menores de 20 anos; Tabela 2), dos quais 59 apresentam dentes (Tabela 3), exumados em três sítios arqueológicos: Solcor-3, Coyo-3 e Quitor-6. Esses sítios representam quatro momentos distintos da pré-história atacamenha (Tabela 4).

A análise dos esqueletos foi realizada por Walter Neves e Maria Antonietta Costa durante a década de 1980. Oito marcadores osteológicos foram inspecionados sem a utilização de qualquer recurso extra, como lupa ou iluminações especiais. Especificidades da análise de cada marcador estão descritas a seguir:

1) As infecções foram computadas por presença ou ausência nas seguintes regiões anatômicas: crânio (abóbada, face alveolar, face não alveolar, base), mandíbula (corpo alveolar, corpo não alveolar, ramo), coluna cervical, torácica e lombar (corpo, arco e processo, superfície articular), costelas (proximal, intermediária, distal), esterno (manúbrio, corpo, processo xifóide), escápula, clavícula, úmero, rádio, ulna, carpos, metacarpos, coxal, fêmur, patela, tíbia, fíbula, tarsos, metatarsos (direitos e esquerdos), falanges da mão, sacro, cocci e falanges do pé. A aferição do tipo de infecção foi feita segundo Ortner e Puchar (1981).

2) Hiperostose porótica foi analisada nas seguintes regiões anatômicas: órbita direita e esquerda, parietal direito e esquerdo e frontal. Cada região anatômica recebeu o termo presente ou ausente. Não foi considerada a cicatrização das lesões.

3) Traumas foram analisados por presença ou ausência nas seguintes regiões anatômicas: crânio (frontal, occipital, mandíbula, parietal direito e esquerdo, temporal direito e esquerdo, face direita e esquerda), costelas (direitas e esquerdas), esterno, clavícula medial, intermediária e lateral (direita e esquerda), úmero, rádio, ulna, fêmur, tíbia e fíbula (proximal, medial e distal do lado direito e esquerdo), primeiro ao quinto metatarso e metacarpo (proximal, medial e distal do lado direito e esquerdo) e coxal (direito e esquerdo).

4) Hipoplasias lineares do esmalte dentário foram computadas nos doze dentes anteriores: quatro caninos, quatro incisivos centrais e quatro incisivos laterais. 
Tabela 2 - Distribuição das idades estimadas (em anos) dos 90 indivíduos dos quatro períodos analisados e seus respectivos números amostrais.

\begin{tabular}{|c|c|c|c|}
\hline Solcor-3 pré & Solcor-3 Tiw & Coyo-3 & Quitor-6 \\
\hline 0 & 0 & 0,085 & 0,5 \\
\hline 0 & 0 & 0,085 & 0,5 \\
\hline 0 & 0,25 & 0,5 & 0,5 \\
\hline \multicolumn{4}{|l|}{0} \\
\hline $\begin{array}{l}0 \\
0\end{array}$ & 0,5 & 0,5 & 0,75 \\
\hline 0,25 & 1 & 0,5 & 3 \\
\hline 0,5 & 1,75 & 0,75 & 3 \\
\hline 0,5 & 2 & 0,75 & 3,5 \\
\hline 0,5 & 2 & 1 & 4 \\
\hline 0,5 & 2,5 & 2 & 4 \\
\hline 0,75 & 3 & 2,5 & 7 \\
\hline $\begin{array}{c}0,75 \\
1\end{array}$ & \multicolumn{2}{|c|}{1} & 10,5 \\
\hline $\begin{array}{l}1 \\
1\end{array}$ & 4 & 3 & 14 \\
\hline 1,5 & 4 & 3,5 & \\
\hline 1,5 & 5 & 3,5 & \\
\hline 1,5 & 10 & 5 & \\
\hline 2 & 17,5 & 12 & \\
\hline 2 & 17,5 & 15 & \\
\hline \multicolumn{4}{|l|}{2} \\
\hline \multicolumn{4}{|l|}{2} \\
\hline \multicolumn{4}{|l|}{2,5} \\
\hline \multicolumn{4}{|l|}{2,5} \\
\hline \multicolumn{4}{|l|}{3} \\
\hline \multicolumn{4}{|l|}{3} \\
\hline \multicolumn{4}{|l|}{3} \\
\hline \multicolumn{4}{|l|}{4} \\
\hline \multicolumn{4}{|l|}{7} \\
\hline \multicolumn{4}{|l|}{8} \\
\hline \multicolumn{4}{|l|}{9} \\
\hline \multicolumn{4}{|l|}{10} \\
\hline \multicolumn{4}{|l|}{11} \\
\hline \multicolumn{4}{|l|}{12} \\
\hline \multicolumn{4}{|l|}{12} \\
\hline \multicolumn{4}{|l|}{12,5} \\
\hline \multicolumn{4}{|l|}{15} \\
\hline \multicolumn{4}{|l|}{18} \\
\hline \multicolumn{4}{|l|}{18,5} \\
\hline \multicolumn{4}{|l|}{19} \\
\hline$N=41$ & $N=18$ & $N=18$ & $N=13$ \\
\hline
\end{tabular}


Tabela 3 - Distribuição das idades estimadas (em anos) dos 59 individuos com dentição nos quatro períodos analisados e as respectivas médias da idade dos indivíduos com somente dentição decídua (normal) e somente dentição permanente (em negrito). Os indivíduos que apresentam ambas as dentições estão marcados com um asterisco $(*)$.

\begin{tabular}{|c|c|c|c|}
\hline Solcor-3 pre Tiwanaku & Solcor-3 Tiwanaku & Coyo-3 & Quitor-6 \\
\hline 0,5 & 0,5 & 0,75 & 3 \\
\hline 0,5 & 1 & 2 & 3,5 \\
\hline 0,5 & 2 & 2,5 & 3,5 \\
\hline 0,5 & 2 & 3 & 4 \\
\hline 0,75 & 3 & 3,5 & 4 \\
\hline 0,75 & 3 & 3,5 & 7* \\
\hline 1 & 4 & $5 *$ & $10,5^{*}$ \\
\hline 1 & 4 & 12 & 14 \\
\hline 1,5 & 5 & 15 & \\
\hline 1,5 & $10 *$ & & \\
\hline 1,5 & 17,5 & & \\
\hline 2 & 17,5 & & \\
\hline 2 & & & \\
\hline 2,5 & & & \\
\hline 3 & & & \\
\hline 3 & & & \\
\hline 3 & & & \\
\hline 3 & & & \\
\hline 4 & & & \\
\hline $7 *$ & & & \\
\hline $8^{*}$ & & & \\
\hline 9* & & & \\
\hline $10 *$ & & & \\
\hline 11 & & & \\
\hline 12 & & & \\
\hline 12 & & & \\
\hline 12,5 & & & \\
\hline 15 & & & \\
\hline 18 & & & \\
\hline 18,5 & & & \\
\hline Média (decídua) & Média (decídua) & Média (decídua) & Média (decídua) \\
\hline 2,89 & 3,45 & 2,89 & 5,07 \\
\hline Média (permanente) & Média (permanente) & Média (permanente) & Média (permanente) \\
\hline 12,09 & 15 & 10,67 & 10,5 \\
\hline
\end{tabular}


Tabela 4 - Datações dos sítios analisados neste trabalho (em anos radiocarbônicos).

\begin{tabular}{ccc}
\hline Sítio & Período & Cronologia* \\
\hline Solcor-3 & Pré Tiwanaku & $250 \pm 150$ A.D. até \\
& & $480 \pm 60$ A.D. \\
Solcor-3 & Auge da influência & $480 \pm 80$ A.D. até \\
& Tiwanaku & $920 \pm 120$ A.D. \\
Coyo-3 & Final da infuência & $910 \pm 70$ A.D. até \\
& Tiwanaku & $960 \pm 50$ A.D. \\
& & \\
Quitor-6 & Pós Tiwanaku & $920 \pm 70$ A.D. até \\
& & $1240 \pm 70$ A.D. \\
\hline
\end{tabular}

* datações obtidas em Costa-Junqueira et al. (1998).

5) Cáries e abcessos foram analisadas em todos os dentes, no caso do primeiro marcador, e todos os alvéolos, no caso do segundo marcador, disponíveis.

6) A análise de desgaste dentário foi feita seguindo a metodologia de Molnar (1971) em todos os dentes disponíveis.

7) A estatura foi inferida a partir da medição do comprimento do fêmur sem as epífises.

A metodologia aqui empregada é a comparação das freqüências, valores absolutos (no caso de estatura) ou das médias (no caso de desgaste dentário) de oito marcadores osteológicos entre os quatro períodos analisados. Os dados estão registrados em fichas osteológicas preenchidas no momento da análise esqueletal. Os marcadores osteológicos utilizados na comparação são: infecções inespecíficas (periostite e osteomilite, subdivididas em localizada e extensa), hiperostose porótica, traumas, hipoplasias lineares do esmalte dentário, cáries, abcessos, desgaste dentário e estatura. 
O ponto de partida da comparação é a verificação da distribuição das idades em cada uma das amostras. A fim de evitar viés amostral, foi testada primeiramente a existência ou não de correlação (Spearman r) entre idade de morte dos indivíduos e freqüência ou média de cada um dos marcadores osteológicos (com exceção de estatura, cujo procedimento é explicado no fim desta seção). Em seguida, foi utilizado o teste ANOVA não paramétrico (Kruskal-Wallis) para comparação das idades médias entre os períodos. Não havendo diferença significativa entre as idades médias, mesmo existindo correlação significativa do marcador com idade, tornou-se desnecessário realizar alterações na amostra. As alterações na amostra - e possíveis repercussões na freqüência ou média -, quando realizadas, estão mostradas nas tabelas da seção Resultados entre parênteses ao lado dos originais - sem correção de amostra - para que fosse possível comparar a magnitude da alteração.

A representatividade dos ossos ou dos dentes é outro ponto que poderia enviesar a comparação entre os períodos. Devido a processos tafonômicos, indivíduos mais jovens tendem a preservar menos ossos que indivíduos mais velhos (Walker et al., 1988; Bello et al., 2006). Esse fenômeno pode causar um viés na amostra quando é utilizada região anatômica, dente ou alvéolo como unidade de análise. Um sítio, por exemplo, que apresente preservação dos ossos ou dos dentes correlacionada positivamente com a idade de morte do indivíduo e, também, correlação positiva do marcador osteológico com idade, tende a ter freqüências mais altas do marcador se comparada com um sítio sem preservação diferencial por idade. A fim de afastar tal possibilidade, foi calculada a correlação (Spearman r) entre representatividade de ossos ou de dentes ${ }^{2}$ e idade dos indivíduos, juntando os quatro períodos. Em seguida, para cada um dos marcadores, foi realizado o mesmo teste em cada período separadamente.

No caso da correlação acima apresentar significância estatística, foi adotado um sistema de correção. Ele é baseado na substituição da frequência absoluta total do período por uma média (em porcentagem). Esta última é calculada atribuindo uma porcentagem para cada indivíduo do período conforme o número de regiões anatômicas, dentes ou

\footnotetext{
${ }^{2}$ A representatividade de ossos ou dentes foi calculada adaptando o índice BRI (bone representation index), pela fórmula: BRI = 100 x Número de regiões anatômicas, alvéolo ou dentes presentes/ Número de regiões anatômicas, alvéolos ou dentes teóricos. O índice pode ser calculado por esqueleto ou por sítio, no último caso faz-se uma média dos BRIs de todos os esqueletos do sítio. Esqueletos ou sítios com índice acima de 50 $\%$ podem ser considerados bem representados (Bello et al., 2006).
} 
alvéolos afetados. A média do período atribui, portanto, pesos iguais para todos os indivíduos (o que não ocorre com as freqüências absolutas). Dessa maneira, os quatro períodos comparados não apresentariam diferença quanto ao BRI, já que indivíduos com preservação diferente teriam o mesmo peso na composição da média em cada período. Por exemplo, se um período apresentar três indivíduos com freqüências absolutas de cáries de 2/10, 3/10 e 2/5; a frequência absoluta total do período seria de 7/25 (em porcentagem seria 28\%). Caso seja usado a média (em porcentagem) dos indivíduos ter-se-ia $(20 \%+30 \%+$ $40 \%) / 3=30 \%$. Este último valor, portanto, é o valor corrigido. Nesses casos, o valor passaria a ser uma porcentagem, ao invés da freqüência absoluta. A vantagem dessa estratégia é que se pode observar a magnitude do desvio provocado, ao se comparar - não estatisticamente - a frequência absoluta (é preciso transformar essa frequência em porcentagem) com a média (em porcentagem). É importante destacar que este tipo de correção só foi utilizado na análise usando região anatômica, alvéolo ou dente como unidade de análise, pois somente nesse tipo de análise pode ocorrer o viés. Nos marcadores osteológicos em que a correção foi aplicada, o teste estatístico ANOVA foi utilizado para comparar as médias (em porcentagem) entre os quatro períodos. Os valores não corrigidos (freqüências absolutas) também foram comparados entre si, através de testes Qui-quadrado e Exato de Fisher (descrição pormenorizada no final desta seção).

Baseado no artigo de Erdal e Duyar (1999) foi realizada uma correção nas freqüências dos marcadores dentais cáries e desgaste dentário. Essa correção é baseada na observação de que os dentes anteriores são mais facilmente perdidos em processos tafonômicos do que os posteriores, devido à sua raiz única. A fim de evitar esse viés, os autores sugeriram que seja calculada separadamente a freqüência absoluta de dentes afetados na dentição anterior e na posterior. Em seguida, multiplicam-se os valores por 2/5 e 3/5, respectivamente (proporção de dentes anteriores e posteriores na dentição decídua, já que ela é a única dentição analisada neste capítulo), e os dois valores são somados. O que é feito nessa correção é dar pesos fixos para a dentição anterior e posterior, a fim de evitar que a tafonomia possa distorcer essas proporções anatômicas. No caso do desgaste dentário é feito o mesmo procedimento, só que se multiplicam médias de desgaste ao invés de freqüências absolutas. Essa correção foi feita usando dente como unidade de análise. 
O marcador trauma foi o único que não foi submetido a testes de correção de amostra devido à baixíssima incidência de afetados (ver Resultados).

Depois de realizarmos as devidas correções de amostra foi realizada a comparação propriamente dita entre os períodos. A comparação foi feita usando os dados originais e os corrigidos, conforme o tipo de correção aplicada (ver acima). Utilizou-se dois tipos de unidades de análise. A primeira delas, usando indivíduo como unidade, comparou as freqüências de afetados, considerando que o indivíduo só pode apresentar dois estados: afetado ou não afetado. A segunda, usando região anatômica, dente ou alvéolo como unidade de análise, comparou a freqüência de acometimento desses elementos esqueletais; nessa análise o alvéolo, o dente ou a região anatômica podem apresentar, também, dois estados: afetado ou não afetado. Ambas as análises foram realizadas para cada um dos sete marcadores osteológicos (com exceção de estatura; ver abaixo).

A comparação usando região anatômica, alvéolo ou dente como unidade de análise apresenta a nítida vantagem de aumentar sobremaneira a amostra, permitindo que os testes de qui-quadrado e de Fisher possam revelar de forma mais acurada eventuais diferenças significativas entre os períodos. Porém, essa virtude apresenta, ao mesmo tempo, um problema. Ocorre uma inflação da amostra. Já a análise por indivíduo é um instrumento bastante confiável para a interpretação dos dados, afinal é o indivíduo que apresenta o estado de saúde ou doença e não um fragmento de osso ou dente seu. Esta análise não fragmenta os dados, observando o indivíduo como um todo. Porém, ela tem a limitação de necessitar de uma amostra bastante grande para que os testes estatísticos detectem alterações significativas. Outro problema da análise por indivíduo é a ausência de gradação; o indivíduo pode apresentar apenas dois estados: doente ou saudável. Em suma, as duas análises apresentam limitações diferentes para a interpretação dos dados, devendo ser usadas em conjunto e de forma complementar.

O teste estatístico utilizado para a comparação de frequêencias absolutas, principalmente na análise utilizando indivíduo como unidade, foi o Exato de Fisher, já que os tamanhos amostrais são bastante reduzidos. As comparações usando região anatômica, alvéolo ou dente como unidade de análise foram feitas através do teste Qui-quadrado (usando a correção de Yates), com exceção de hiperostose porótica e hipoplasia linear do esmalte, cujo número amostral muito baixo obrigou a utilização do teste Exato de Fisher. O 
único marcador que não teve seus resultados apresentados sob a forma de freqüências absolutas foi o desgaste dentário. A comparação entre períodos para esse marcador foi feita através do teste ANOVA não paramétrico (Kruskal-Wallis), a fim de comparar médias. Todos os testes estatísticos utilizados neste trabalho adotaram nível de significância de 5 \% (Madrigal, 1998; Beiguelman, 2002).

O marcador infecções foi analisado separadamente para cada uma das suas categorias (periostite e osteomielite) e, também, de forma total (chamada de “infecções total”). A análise total considera que basta uma das categorias de infecções estar presente para o indivíduo ou a região anatômica ser considerada afetada. Quando o termo “infecções” foi utilizado em uma tabela, ele referiu-se a todas as categorias (infecções total, periostite e osteomielite); o termo foi usado em situações que todas as categorias apresentaram os mesmos valores.

A comparação dos marcadores dentais (abcessos, hipoplasia linear do esmalte, desgaste dentário e cáries) só foi realizada para a dentição decídua. Isso se deveu ao reduzido número de dentes permanentes nas amostras.

Infecções (total) e cáries foram submetidos num segundo momento a uma análise na qual somente os indivíduos afetados foram comparados. Tal análise usou o indivíduo como unidade, mas, ao contrário das realizadas anteriormente, levou em conta o grau de afecção do indivíduo (expresso em porcentagem). Utilizou-se, nela, somente indivíduos afetados, pois dessa forma seria possível detectar a extensão da lesão. Os resultados dessa análise são expressos em média para cada período e o teste estatístico utilizado para comparar esses valores é a ANOVA não paramétrica (Kruskall-Wallis). Os demais marcadores não foram submetidos a essa análise porque apresentaram número muito baixo de indivíduos afetados (dois ou mais períodos com três ou menos indivíduos afetados).

Por fim, o marcador osteológico estatura foi submetido a uma análise diferente do restante. A estatura nos subadultos de San Pedro de Atacama foi analisada utilizando o comprimento do fêmur sem as epífises, uma vez que essa medida é uma boa aproximação da estatura do indivíduo (Larsen, 1997). Os dados sobre comprimento do fêmur de cada indivíduo foram plotados na ordenada de um gráfico, cuja abscissa expressa idade. Dessa forma, foi possível visualizar a variação do comprimento do fêmur por idade em cada um dos períodos, e comparar graficamente a diferença entre eles. 


\section{2 - Resultados}

A primeira parte dos resultados consiste na averiguação da confiabilidade da comparação, ou seja, até que ponto os quatro períodos podem ser comparados sem que fatores como idade e preservação diferencial possam enviesar os resultados. A Tabela 5 mostra os resultados do teste de correlação (Spearman r) entre idade e grau de afecção para cada um dos marcadores osteológicos. Hiperostose porótica, infecções (total), osteomielite localizada, cáries, abcessos e desgaste dentário apresentaram correlações significativas, ou seja, quanto mais velho o indivíduo, mais afetado pelo marcador ele o é.

As amostras foram comparadas, então, quanto às suas médias de idade, por marcador, através do teste ANOVA não paramétrico (Kruskal-Wallis). As médias de idade usadas nesses testes e os seus respectivos resultados estão nas Tabelas 6 e 7. Hiperostose porótica e infecções foram os marcadores que apresentaram maior semelhança entre as médias de idade nos quatro períodos ( $\mathrm{P}=0,9393$ e 0,8088 , respectivamente), tornando desnecessário qualquer tipo de correção das amostras. Em contrapartida, os marcadores dentais apresentaram resultados significativos na comparação entre as médias das idades. A única exceção foram as hipoplasias lineares do esmalte que apresentaram valor de P não significativo (0,0557), porém bastante próximo do nível de significância.

Em vista dos resultados oriundos dos marcadores dentais, foi adotada uma correção de amostra para todos eles. Um indivíduo de Quitor-6 ( $\mathrm{n}^{\circ}$ 568) com 10,5 anos de idade foi retirado da amostra, já que esse sítio apresentou a maior média de idade entre os quatro períodos (5). Esse indivíduo foi escolhido por dois motivos. O primeiro refere-se ao fato dele apresentar a maior idade entre os esqueletos de Quitor-6. Retirando-o ocorreu uma diminuição da idade média de 5 para 4,08. O segundo está ligado à baixa representatividade (BRI) desse esqueleto para a dentição decídua: um canino superior (hipoplasia) e um canino superior e dois segundos molares superiores (desgaste dentário, cáries e abcessos). 
Tabela 5 - Valores dos testes de correlação (Spearman r) entre a idade e grau de afecção no indivíduo de cada marcador osteológico, com seus respectivos graus de significância (P).

\begin{tabular}{lcc}
\hline & Spearman $r$ & $P^{*}$ \\
\hline Hiperostose porótica & 0,2499 & $\mathbf{0 , 0 0 4 3}$ \\
Infecção (total) & 0,2264 & $\mathbf{0 , 0 3 3 9}$ \\
Infecção (total) afetados & $-0,4423$ & 0,0509 \\
Periostite localizada & 0,0493 & 0,6486 \\
Periostite generalizada & 0,1062 & 0,3248 \\
Osteomielite localizada & 0,2538 & $\mathbf{0 , 0 1 7 0}$ \\
Osteomielite generalizada & 0,0509 & 0,6377 \\
Cáries (dentição decídua) & 0,6890 & $<\mathbf{0 , 0 0 0 1}$ \\
Cáries (dentição decídua) afetados & 0,3062 & 0,1366 \\
Abcessos (dentição decídua) & 0,4341 & $\mathbf{0 , 0 0 2 6}$ \\
Desgaste dentário (decídua) & 0,8786 & $<\mathbf{0 , 0 0 0 1}$ \\
Hipoplasia (dentição decídua) & 0,1952 & 0,2275 \\
\hline
\end{tabular}

*os valores em negrito foram considerados significativos $(<5 \%)$. 
Tabela 6 - Médias das idades e seus respectivos tamanhos amostrais, por marcador.

\begin{tabular}{lcccc}
\hline & Solcor-3 pré & Solcor-3 Tiw & Coyo-3 & Quitor-6* \\
\hline Hiperostose porótica & 4,5870 & 4,2969 & 3,5596 & 4,0000 \\
$\mathrm{~N}$ & 23 & 16 & 14 & 13 \\
Infecções & 4,8269 & 4,1389 & 2,9816 & 4,0000 \\
$\mathrm{~N}$ & 39 & 18 & 18 & 13 \\
Infecções (total) afetados & 7,0300 & 5,5000 & 3,7500 & 3,1500 \\
$\mathrm{~N}$ & 8 & 5 & 2 & 5 \\
Cáries & 2,7381 & 3,7778 & 2,8929 & 5,0000 \\
$\mathrm{~N}$ & 21 & & & $(4,08)$ \\
Cáries afetados & 4,3100 & 4,6700 & 3,3800 & $7(6)$ \\
$\mathrm{N}$ & 8 & 6 & 4 & 7 \\
Abcessos & 2,6591 & 3,4500 & 2,8929 & 5,0000 \\
$\mathrm{~N}$ & 22 & 10 & 7 & $(4,08)$ \\
Desgaste dentário & 2,8158 & 3,7778 & 2,8929 & 5,0000 \\
$\mathrm{~N}$ & 19 & 9 & 7 & $(4,08)$ \\
Hipolasias & 2,6667 & 3,0000 & 2,1835 & 5,0000 \\
& & & & $(4,08)$ \\
\hline $\mathrm{N}$ total & 15 & 8 & 10 & $7(6)$ \\
\hline
\end{tabular}

* os valores entre parênteses são as médias de idade e tamanhos amostrais corrigidos (retirada de um indivíduo em Quitor-6). 
Tabela 7 - Valores dos testes de ANOVA (Kruskal-Wallis) comparando as idades médias dos indivíduos entre os períodos analisados para cada marcador osteológico, e seus respectivos graus de significância (P). O mesmo teste foi aplicado às idades médias corrigidas.

\begin{tabular}{lcc}
\hline & Kruskal-Wallis* & Corrigido \\
\hline Hiperostose porótica & 0,4044 & \\
Infecção & $(P=0,9393)$ & \\
Infecção (total) afetados & 0,9689 & \\
& $(P=0,8088)$ & \\
Cáries (dentição decídua) & 1,427 & \\
& $(P=0,6992)$ & \\
Cáries (dentição decídua) afetados & 8,637 & 6,949 \\
& $(P=\mathbf{0 , 0 3 4 5 )}$ & $(P=0,0735)$ \\
Abcessos (dentição decídua) & 1,603 & \\
& $(P=0,6587)$ & 6,514 \\
Desgaste dentário (decídua) & 8,315 & $(P=0,0891)$ \\
Hipoplasia (dentição decídua) & $(P=\mathbf{0 , 0 3 9 9 )}$ & 6,277 \\
& 7,913 & $(P=0,0989)$ \\
& $(P=0,0478)$ & 5,830 \\
& 7,573 & $(P=0,1202)$ \\
\hline
\end{tabular}

*os valores em negrito foram considerados significativos $(<5 \%)$.

Dessa forma a média de idade desceu ${ }^{3}$ e o número de dentes na amostra não diminuiu muito. Os resultados das médias de idade antes e depois da correção estão mostrados na Tabela 6. Os valores do teste ANOVA (Kruskall-Wallis) comparando as médias de idade depois da correção estão mostrados na Tabela 7. Pela observação dessa tabela é possível notar que os valores de $\mathrm{P}$ para os quatro marcadores dentais não são significativos depois da retirada do indivíduo de Quitor-6. O marcador hipoplasia linear do esmalte foi também submetido à correção de amostra porque o seu valor de $\mathrm{P}$ na comparação de médias de idade ficou muito próximo do nível de significância $(0,0557)$.

\footnotetext{
${ }^{3} \mathrm{O}$ desvio padrão também sofreu alteração, mas de magnitude muito pequena.
} 
A representatividade de ossos e dentes (índice BRI) nos quatro períodos para cada um dos marcadores está mostrada na Tabela 8. De modo geral, o período Solcor-3 préTiwanaku é o que apresenta a pior preservação, enquanto Quitor-6 apresenta a melhor. O marcador dental abcessos é o que apresenta os maiores índices BRI, considerando os quatro períodos analisados. Os resultados da correlação $r$ de Spearman entre os BRI's dos indivíduos e suas idades para cada um dos marcadores estão fornecidos na Tabela 9. No caso dos marcadores hiperostose porótica e infecções houve correlação positiva significativa, juntando os quatro períodos. Quando foram realizados os testes dentro de cada um dos períodos, observou-se que no primeiro marcador o período que apresentava correlação foi Quitor-6 e no segundo, Coyo-3. Os resultados quanto a desgaste dentário mostraram ausência de correlação significativa entre idade e representatividade (BRI), juntando os quatro períodos. Todavia, quando foram realizados os testes dentro de cada um dos períodos, Quitor-6 apresentou correlação significativa.

Em vista dos resultados acima, os marcadores hiperostose porótica, infecções e desgaste dentário foram corrigidos na análise que utiliza região anatômica, alvéolo ou dente como unidade. A correção foi feita conforme já descrito em Material e Métodos; em síntese, convertendo-se a freqüência absoluta em média (em porcentagem), a fim de eliminar as diferenças entre os BRIs dos indivíduos e dos sítios. No caso de desgaste dentário, que já é calculado em média (porém não em porcentagem), a correção representou apenas a transformação dos resultados da análise usando dente como unidade para os resultados da análise usando indivíduo como unidade (o cálculo da correção é o mesmo do cálculo de desgaste usando indivíduo como unidade), significando, portanto, que a segunda análise é mais confiável.

Os resultados das freqüências relativas do marcador cáries estão apresentados na Tabela 10 e nas Figuras 12 e 13. O primeiro resultado mostra a análise utilizando-se dente como unidade de análise, enquanto a segunda análise utiliza indivíduo como unidade. Quitor-6 apresenta os maiores índices de cáries nas duas análises, apresentando todos os indivíduos com pelo menos uma cárie na dentição decídua. Os três sítios restantes apresentam tendências conflitivas. Na análise utilizando dente como unidade há uma diminuição da freqüência de cáries de Solcor-3 pré-Tiwanaku para Coyo-3, enquanto na análise por indivíduo existe um aumento de Solcor-3 pré-Tiwanaku para Coyo-3. Na 
Tabela 8 - Índice BRI por sítio para cada marcador.

\begin{tabular}{lcccc}
\hline & Solcor-3 pré & Solcor-3 Tiw & Coyo-3 & Quitor-6 \\
\hline Hiperostose porótica & 66,0870 & 81,2500 & 71,4286 & 100 \\
Infecções & 42,0703 & 55,0412 & 54,5267 & 77,6353 \\
Cáries & 33,3333 & 68,8889 & 72,1429 & 71,4286 \\
Abcessos & 71,1364 & 84,0000 & 95,0000 & 87,8571 \\
Desgaste dentário & 32,1053 & 65,0000 & 69,2857 & 69,2857 \\
Hipolasias & 36,1111 & 67,7083 & 71,6667 & 77,3810 \\
\hline
\end{tabular}

Tabela 9 - Correlações (Spearman r) entre as idades e a porcentagem de afecção dos indivíduos pelos marcadores osteológicos, com seus respectivos graus de significância (P); os valores em negrito foram considerados significativos $(<5 \%)$.

\begin{tabular}{lcc}
\hline & Spearman r & $\mathrm{P}$ \\
\hline Hiperostose porótica & 0,3381 & $\mathbf{0 , 0 0 5 5 *}$ \\
Infecções & 0,3522 & $\mathbf{0 , 0 0 0 8 * *}$ \\
Cáries (dentição decídua) & 0,1811 & 0,2395 \\
Abcessos (dentição decídua) & $-0,1449$ & 0,3422 \\
Desgaste dentário (decídua) & 0,0895 & $0,5728^{* * *}$ \\
Hipoplasia (dentição decídua) & $-0,0819$ & 0,6152 \\
\hline * Quitor-6 apresenta resultado significativo & & \\
** Coyo-3 apresenta resultado significativo & & \\
*** Quitor-6 apresenta resultado significativo & &
\end{tabular}

Tabela 10 - Porcentagem e freqüência absoluta de dentes cariados e de indivíduos afetados por período analisado; correção da freqüência de cáries usando dente como unidade segundo Erdal e Duyar (1999); os valores entre parênteses são os resultados corrigidos para o viés idade nas amostras (retirada de um indivíduo em Quitor-6).

\begin{tabular}{lccccc}
\hline & \multicolumn{2}{c}{$\begin{array}{c}\text { cáries (decídua) } \\
\text { por dente }\end{array}$} & $\begin{array}{c}\text { Cáries } \\
\text { por dente } \\
\text { Erdal e Duyar }\end{array}$ & \multicolumn{2}{c}{$\begin{array}{c}\text { cáries (decídua) } \\
\text { por indivíduo }\end{array}$} \\
\hline Solcor-3 (pre) & frequência absoluta & porcentagem & porcentagem & frequência absoluta & porcentagem \\
Solcor-3 (Tiw) & $53 / 140$ & 37,86 & 37,05 & $\mathbf{8 / 2 1}$ & $\mathbf{3 8 , 1}$ \\
Coyo-3 & $33 / 124$ & $\mathbf{2 6 , 6 1}$ & $\mathbf{2 6 , 5 7}$ & $\mathbf{6 / 9}$ & $\mathbf{6 6 , 6 7}$ \\
Quitor-6 & $16 / 101$ & $\mathbf{1 5 , 8 4}$ & $\mathbf{1 5 , 3 7}$ & $4 / 7$ & $\mathbf{5 7 , 1 4}$ \\
\hline
\end{tabular}




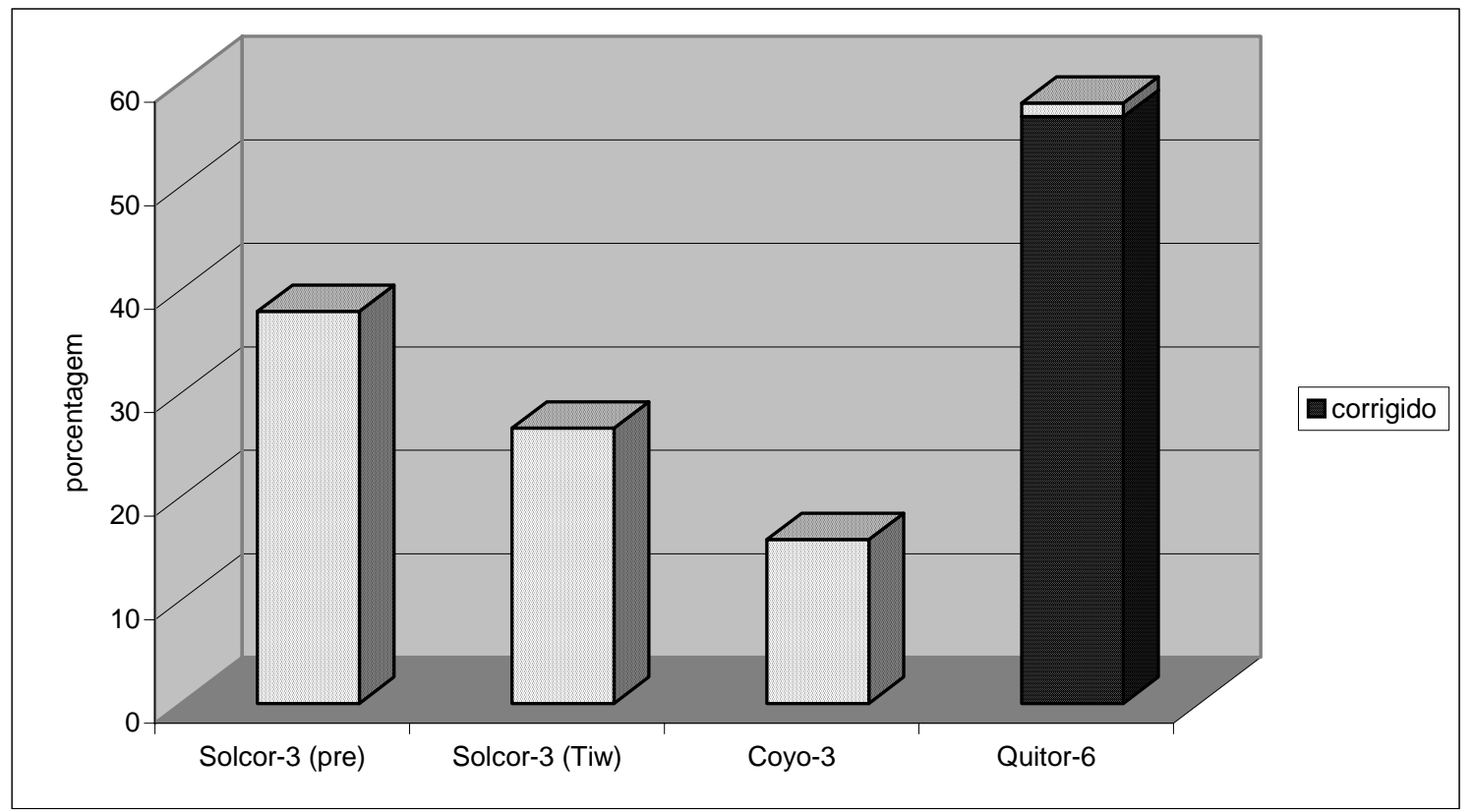

Figura 12 - Porcentagem de dentes afetados por cáries (dentição decídua) em cada sítio analisado; o valor corrigido refere-se ao viés idade nas amostras (retirada de um indivíduo em Quitor-6).

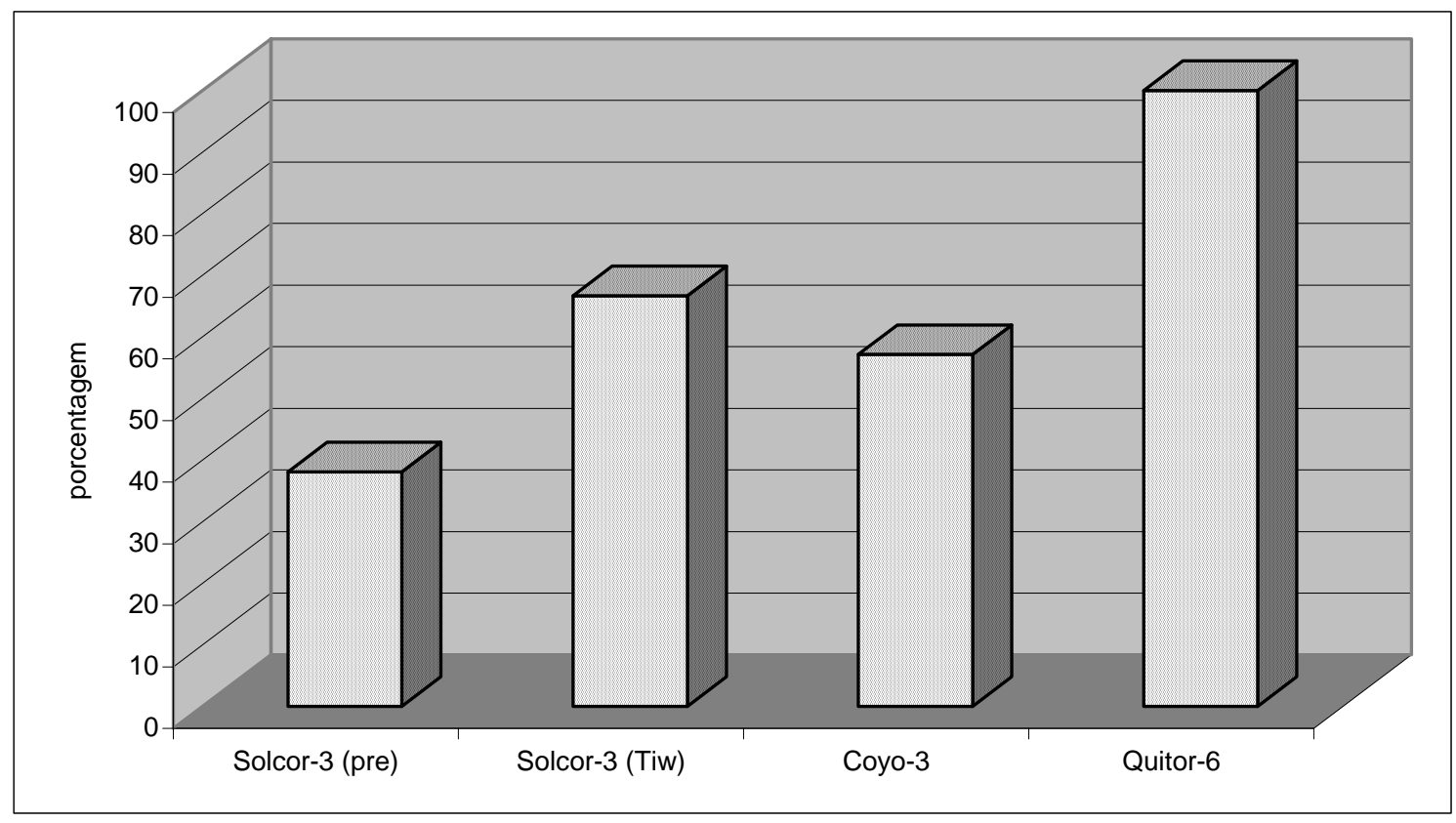

Figura 13 - Porcentagem de indivíduos afetados por cáries (dentição decídua) em cada sítio analisado. 
análise utilizando dente como unidade, Quitor-6 apresenta resultados significativamente diferentes dos demais, enquanto nos outros períodos, somente Coyo-3 apresenta resultado significativo em relação à Solcor-3 pré-Tiwanaku (Tabela 11). Na análise utilizando indivíduo como unidade, o único par de períodos que apresentou diferenças significativas foi Solcor-3 pré-Tiwanaku e Quitor-6 (Tabela 12). As análises dos indivíduos afetados por cáries estão apresentadas na Tabela 13 e na Figura 14. Solcor-3 Tiwanaku destacou-se com a maior média (em porcentagem) de dentes cariados nos indivíduos afetados, seguido por Quitor-6, Solcor-3 Tiwanaku e Coyo-3. O teste ANOVA não paramétrico não acusou diferenças significativas entre as médias dos períodos (Tabela 14). Os valores corrigidos para o viés idade, representatividade (índice BRI) e correção de Erdal e Duyar (1999) não apresentaram resultados diferentes dos valores originais, nem na ordenação dos períodos, nem nas significâncias estatísticas (Tabelas 10, 11 e 12, e Figura 12).

Os resultados das freqüências relativas de abcessos estão na Tabela 15 e Figuras 15 e 16. Tanto na análise por alvéolo como por indivíduo, Quitor-6 e Coyo-3 apresentaram o maior índice de afetados. Na primeira análise, Solcor-3 Tiwanaku apresenta a menor frequência de abcessos, enquanto que na segunda Solcor-3 pré-Tiwanaku ocupa tal posição. Os testes estatísticos não apresentaram resultados significativos (Tabelas 16 e 17), possivelmente devido ao baixo número de alvéolos afetados nos quatro períodos. Os valores corrigidos alteraram muito pouco a ordem dos períodos e não mudaram a significância dos testes estatísticos (Tabelas 15, 16 e 17, e Figuras 15 e 16).

Os resultados das médias de desgaste dentário estão na Tabela 18 e Figuras 17 e 18. Como foi avaliado nos testes do viés idade e representatividade (BRI) entre os períodos, o resultado da análise por indivíduo é mais confiável que a análise por dente. No entanto, neste caso isto não é tão marcante, pois os resultados de ambas as análises são muito semelhantes. Quitor-6 apresenta o maior desgaste, seguido de Solcor-3 Tiwanaku, Coyo-3 e Solcor-3 pré-Tiwanaku. O teste estatístico ANOVA não paramétrico acusou diferença significativa entre as médias dos períodos, e os pós testes de Dunn apresentaram diferença significativa entre Solcor-3 pre e Quitor-6 (Tabela 14; usando indivíduo como unidade). Os valores corrigidos não alteraram a ordem dos períodos, nem a significância dos testes estatísticos (Tabela 14 e 18). 
Tabela 11 - Resultados dos testes Qui-quadrado e dos valores de P comparando-se as freqüências de dentes afetados por cáries entre pares de períodos (dentição decídua); os valores em negrito foram considerados significativos $(<5 \%)$.

\begin{tabular}{|c|c|c|c|}
\hline Períodos & Solcor-3 (pre) & Solcor-3 (Tiw) & Coyo-3 \\
\hline Solcor-3 (Tiw) & $\begin{array}{c}3,291 \\
(P=0,0697)\end{array}$ & $X$ & \\
\hline Coyo-3 & $\begin{array}{c}12,861 \\
(P=0,0003)\end{array}$ & $\begin{array}{c}3,185 \\
(P=0,0743)\end{array}$ & $X$ \\
\hline Quitor-6* & $\begin{array}{c}8,728(7,461) \\
(P=0,0031 / 0,0063\end{array}$ & $\begin{array}{c}21,326(19,324) \\
(P<0,0001 /<0,0001)\end{array}$ & $\begin{array}{c}36,602(34,161) \\
(P<0,0001 /<0,0001)\end{array}$ \\
\hline
\end{tabular}

* os valores entre parênteses e depois da barra são os resultados das freqüências corrigidas para o viés idade nas amostras (retirada de um indivíduo em Quitor-6).

Tabela 12 - Resultados dos testes Exatos de Fisher comparando-se as freqüências de indivíduos afetados por cáries entre pares de períodos (dentição decídua); os valores em negrito foram considerados significativos $(<5 \%)$.

\begin{tabular}{cccc}
\hline Períodos & Solcor-3 (pre) & Solcor-3 (Tiw) & Coyo-3 \\
\hline Solcor-3 (Tiw) & 0,2360 & $\mathrm{X}$ & \\
Coyo-3 & 0,4184 & 1,0000 & $\mathrm{X}$ \\
Quitor-6* $^{*}$ & $\mathbf{0 , 0 0 6 9 ( \mathbf { 0 , 0 1 5 9 } )}$ & $0,2125(0,2286)$ & $0,1923(0,1923)$ \\
\hline
\end{tabular}

* os valores entre parênteses são os resultados das freqüências corrigidas para o viés idade nas amostras (retirada de um indivíduo em Quitor-6)

Tabela 13 - Média (em porcentagem) dos indivíduos afetados por cáries e infecções (total) em cada período e suas respectivas amostras.

\begin{tabular}{lcccc}
\hline & \multicolumn{2}{c}{$\begin{array}{c}\text { cáries (decídua) } \\
\text { afetados }\end{array}$} & \multicolumn{2}{c}{$\begin{array}{c}\text { infecção (total) } \\
\text { afetados }\end{array}$} \\
\hline & amostra & média & amostra & média \\
Solcor-3 (pré) & $\mathbf{8}$ & $\mathbf{7 2 , 5 8}$ & $\mathbf{8}$ & $\mathbf{6 , 3 6}$ \\
Solcor-3 (Tiw) & $\mathbf{6}$ & $\mathbf{4 8 , 3 1}$ & $\mathbf{5}$ & $\mathbf{1 7 , 1 5}$ \\
Coyo-3 & $\mathbf{4}$ & $\mathbf{3 1 , 9 9}$ & $\mathbf{2}$ & $\mathbf{3 , 8 1}$ \\
Quitor-6 & $\mathbf{7}$ & $\mathbf{6 4 , 2 4}$ & $\mathbf{5}$ & $\mathbf{5 , 6 1}$ \\
\hline
\end{tabular}


Tabela 14 - Valores dos testes de ANOVA (Kruskal-Wallis) comparando-se as médias nos indivíduos entre os períodos analisados e seus respectivos níveis de significância (P). O teste para o marcador desgaste dentário utilizou média de grau de desgaste, já infecções (total) e cáries utlizaram média em porcentagem somente para os indivíduos afetados. Os valores em negrito foram considerados significativos $(<5 \%)$.

\begin{tabular}{lcc}
\hline & Kruskal-Wallis & $\mathrm{P}$ \\
\hline Desgaste dentário (decídua) & $11,721(10,582)$ & $\mathbf{0 , 0 0 8 4}(\mathbf{0 , 0 1 4 2})^{\star}$ \\
Infecção (total) afetados & 2,344 & 0,5041 \\
Cáries (decídua) afetados & 6,133 & 0,1053 \\
\hline
\end{tabular}

* o par Solcor-3 pré e Quitor-6 apresentou diferença significativa no pós teste de Dunn; o valor entre parênteses é o resultado das médias corrigidas para o viés idade nas amostras (retirada de um indivíduo em Quitor-6).

Tabela 15 - Freqüência absoluta e porcentagem de alvéolos e de indivíduos afetados por abcessos por período analisado; os valores entre parênteses são os resultados corrigidos para o viés idade nas amostras (retirada de um indivíduo em Quitor-6).

\begin{tabular}{|c|c|c|c|c|}
\hline & \multicolumn{2}{|c|}{$\begin{array}{l}\text { abcessos (decídua) } \\
\text { por alvéolo }\end{array}$} & \multicolumn{2}{|c|}{$\begin{array}{l}\text { abcessos (decídua) } \\
\text { por indivíduo }\end{array}$} \\
\hline & frequência absoluta & porcentagem & frequência absoluta & porcentagem \\
\hline Solcor-3 (pre) & $8 / 313$ & 2,56 & $3 / 22$ & 13,64 \\
\hline Solcor-3 (Tiw) & 2/168 & 1,19 & $2 / 10$ & 20,00 \\
\hline Coyo-3 & $6 / 133$ & 4,51 & $2 / 7$ & 28,57 \\
\hline Quitor-6 & $5 / 123(120)$ & $4,06(4,17)$ & $2 / 7(6)$ & $28,57(33,33)$ \\
\hline
\end{tabular}

Tabela 16 - Resultados dos testes Qui-quadrado e dos valores de P comparando-se as freqüências de alvéolos afetados por abcessos entre pares de períodos (dentição decídua).

\begin{tabular}{cccc}
\hline Períodos & Solcor-3 (pre) & Solcor-3 (Tiw) & Coyo-3 \\
\hline Solcor-3 (Tiw) & 0,4428 & & \\
& $(P=0,5058)$ & $X$ & \\
Coyo-3 & 0,6187 & 2,011 & \\
& $(P=0,4315)$ & $(P=0,1562)$ & $X$ \\
Quitor-6 * & $(P=0,6024 / 0,5724)$ & $(P=0,2326 / 0,2191)$ & $(P=0,8604 / 0,8932)$ \\
\hline
\end{tabular}

* os valores entre parênteses e depois da barra são os resultados das freqüências corrigidas para o viés idade nas amostras (retirada de um indivíduo em Quitor-6) 
Tabela 17 - Resultados dos testes Exatos de Fisher comparando-se as freqüências de indivíduos afetados por abcessos entre pares de períodos (dentição decídua).

\begin{tabular}{cccc}
\hline Períodos & Solcor-3 (pre) & Solcor-3 (Tiw) & Coyo-3 \\
\hline Solcor-3 (Tiw) & 0,6367 & $\mathrm{X}$ & \\
Coyo-3 & 0,5688 & 1,0000 & $\mathrm{X}$ \\
Quitor-6 * & $0,5688(0,2855)$ & $1,0000(0,6044)$ & $1,4406(1,0000)$ \\
\hline
\end{tabular}

* os valores entre parênteses são os resultados das freqüências corrigidas para o viés idade nas amostras (retirada de um indivíduo em Quitor-6)

Tabela 18 - Média do grau de desgaste dentário de dentes e de indivíduos por período analisado, assim como a respectiva amostra utilizada; correção da média de desgaste dentário usando dente como unidade segundo adaptação de Erdal e Duyar (1999); os valores entre parênteses são os resultados corrigidos para o viés idade nas amostras (retirada de um indivíduo em Quitor-6).

\begin{tabular}{lccccc}
\hline & \multicolumn{2}{c}{$\begin{array}{c}\text { desgaste dentário (decídua) } \\
\text { por dente }\end{array}$} & $\begin{array}{c}\text { desgaste dentário } \\
\text { por dente } \\
\text { (Erdal e Duyar) }\end{array}$ & $\begin{array}{c}\text { desgaste dentário (decídua) } \\
\text { por indivíduo }\end{array}$ \\
\hline Solcor-3 (pre) & 122 & média & Média & amostra & média \\
Solcor-3 (Tiw) & 117 & 1,66 & 1,64 & 19 & 1,6 \\
Coyo-3 & 97 & 2,12 & 2,13 & 9 & 2,17 \\
Quitor-6 & $97(94)$ & $\mathbf{2 , 6 3 ( 2 , 6 3 )}$ & 2,67 & 7 & 1,8 \\
\hline
\end{tabular}




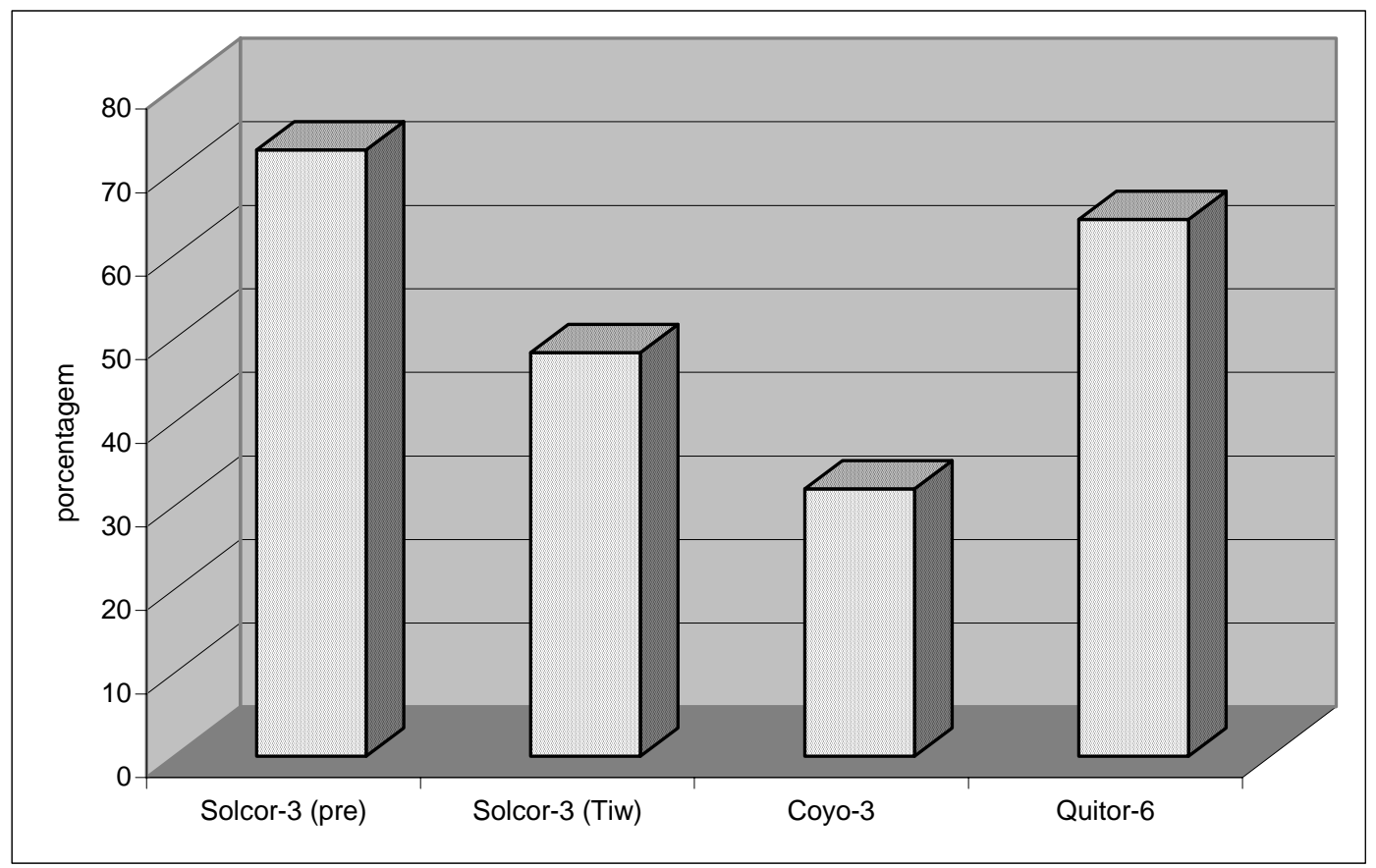

Figura 14 - Média (em porcentagem) do grau de afecção de cáries nos indivíduos afetados (dentição decídua) em cada sítio analisado.

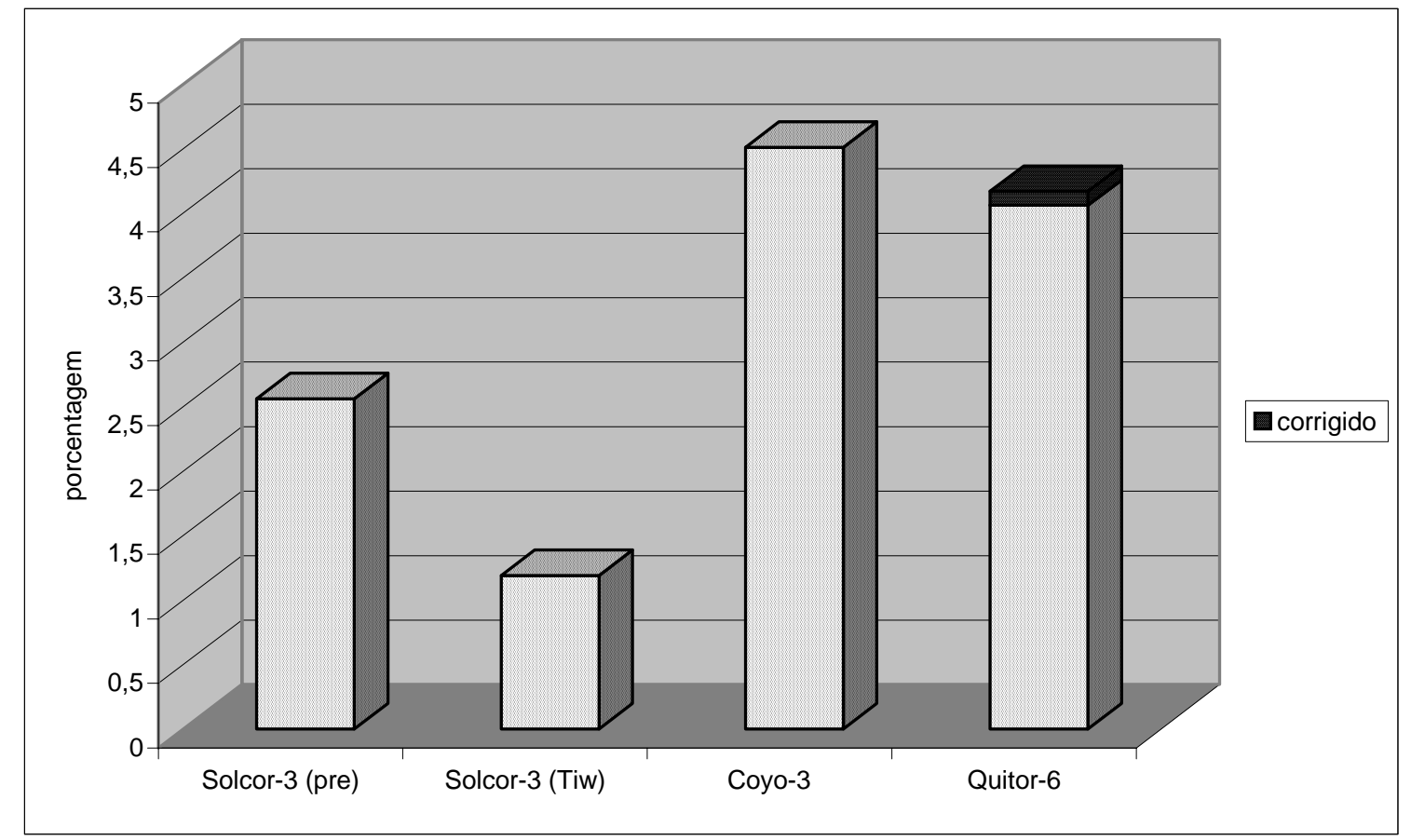

Figura 15 - Porcentagem de alvéolos afetados por abcessos (dentição decídua) em cada sítio analisado; o valor corrigido refere-se ao viés idade nas amostras (retirada de um indivíduo em Quitor-6). 


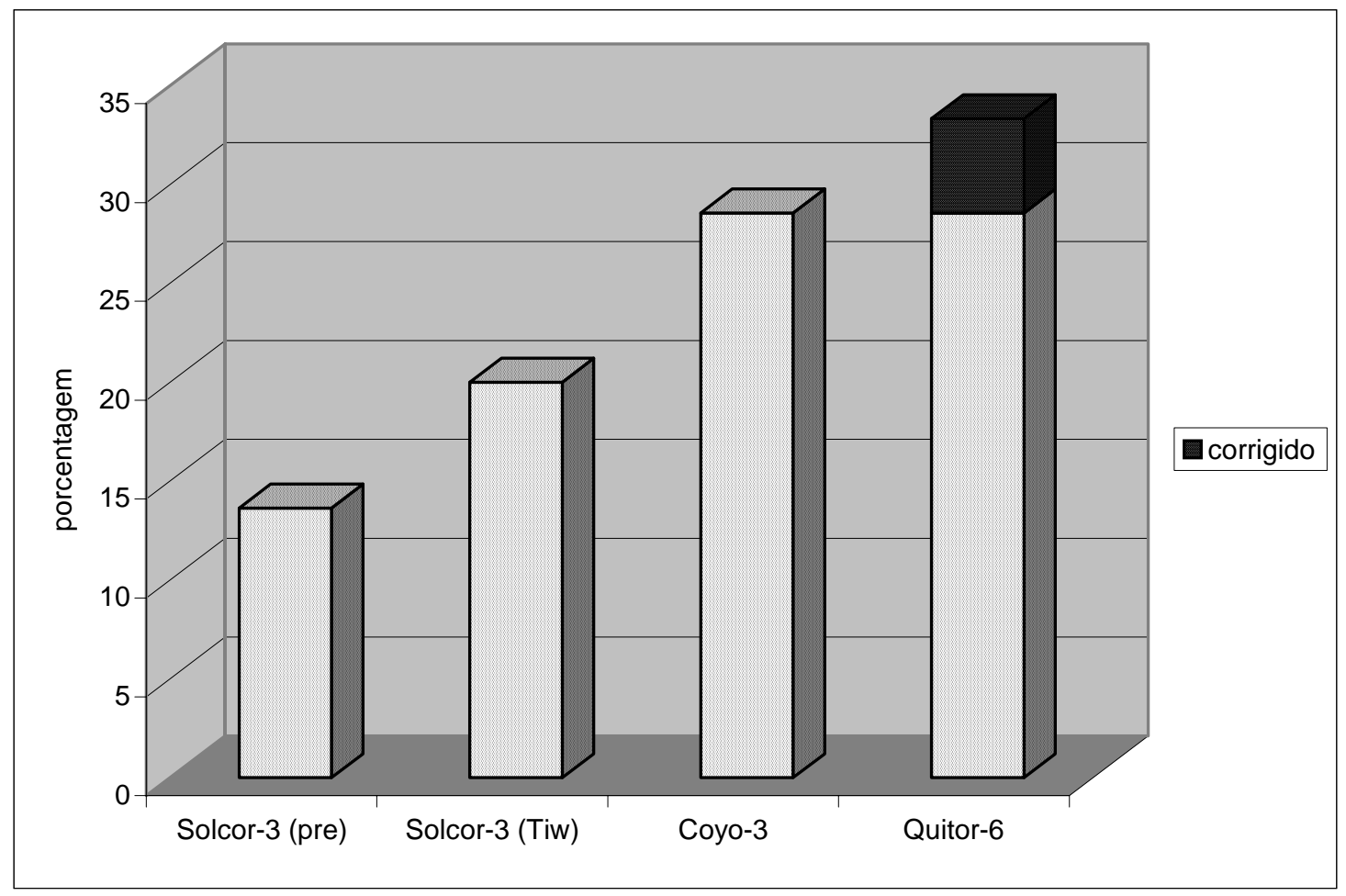

Figura 16 - Porcentagem de indivíduos afetados por abcessos (dentição decídua) em cada sítio analisado; o valor corrigido refere-se ao viés idade nas amostras (retirada de um indivíduo em Quitor-6).

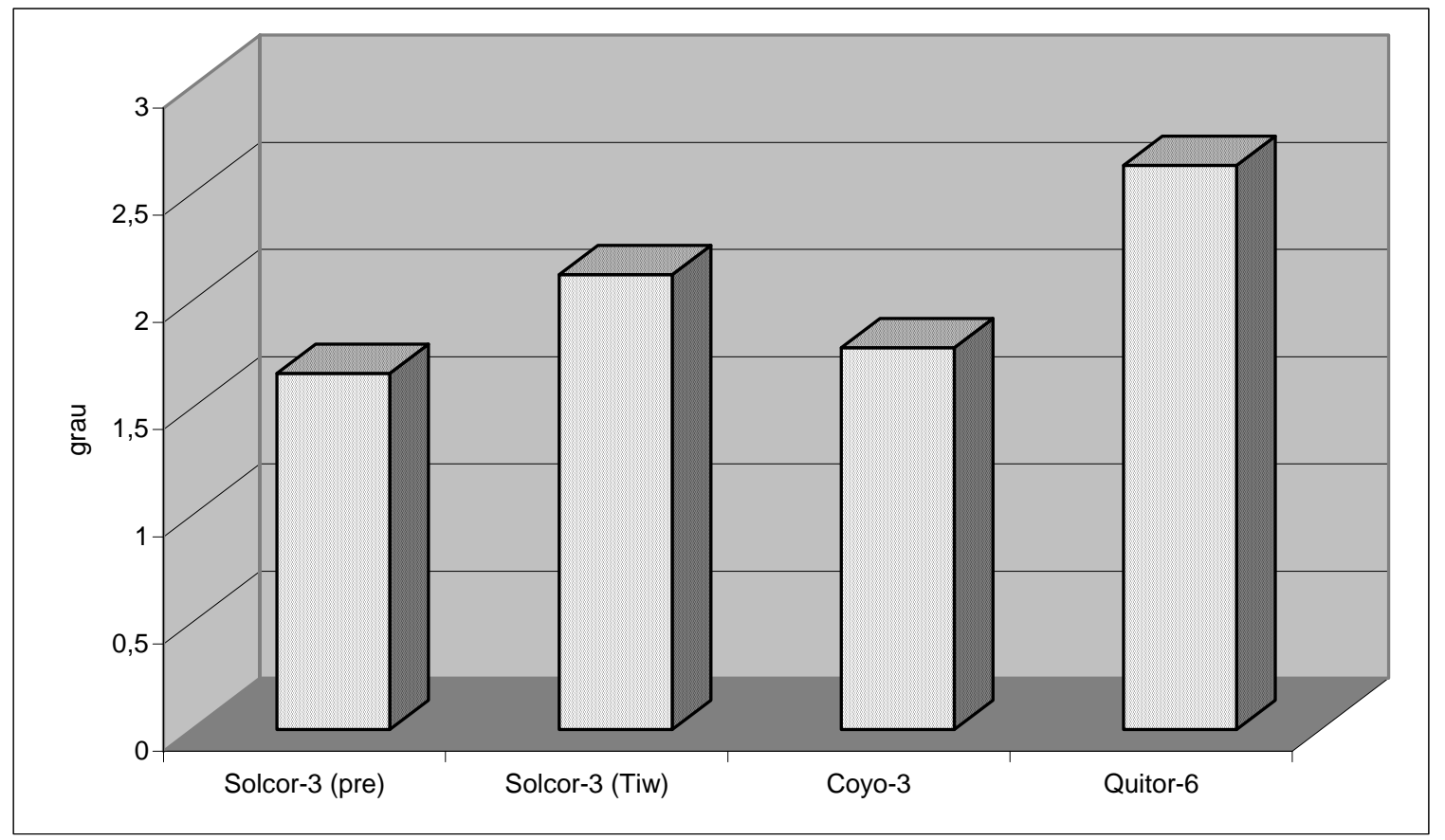

Figura 17 - Média do grau de desgaste dentário usando dente como unidade de análise (dentição decídua) em cada sítio analisado. 


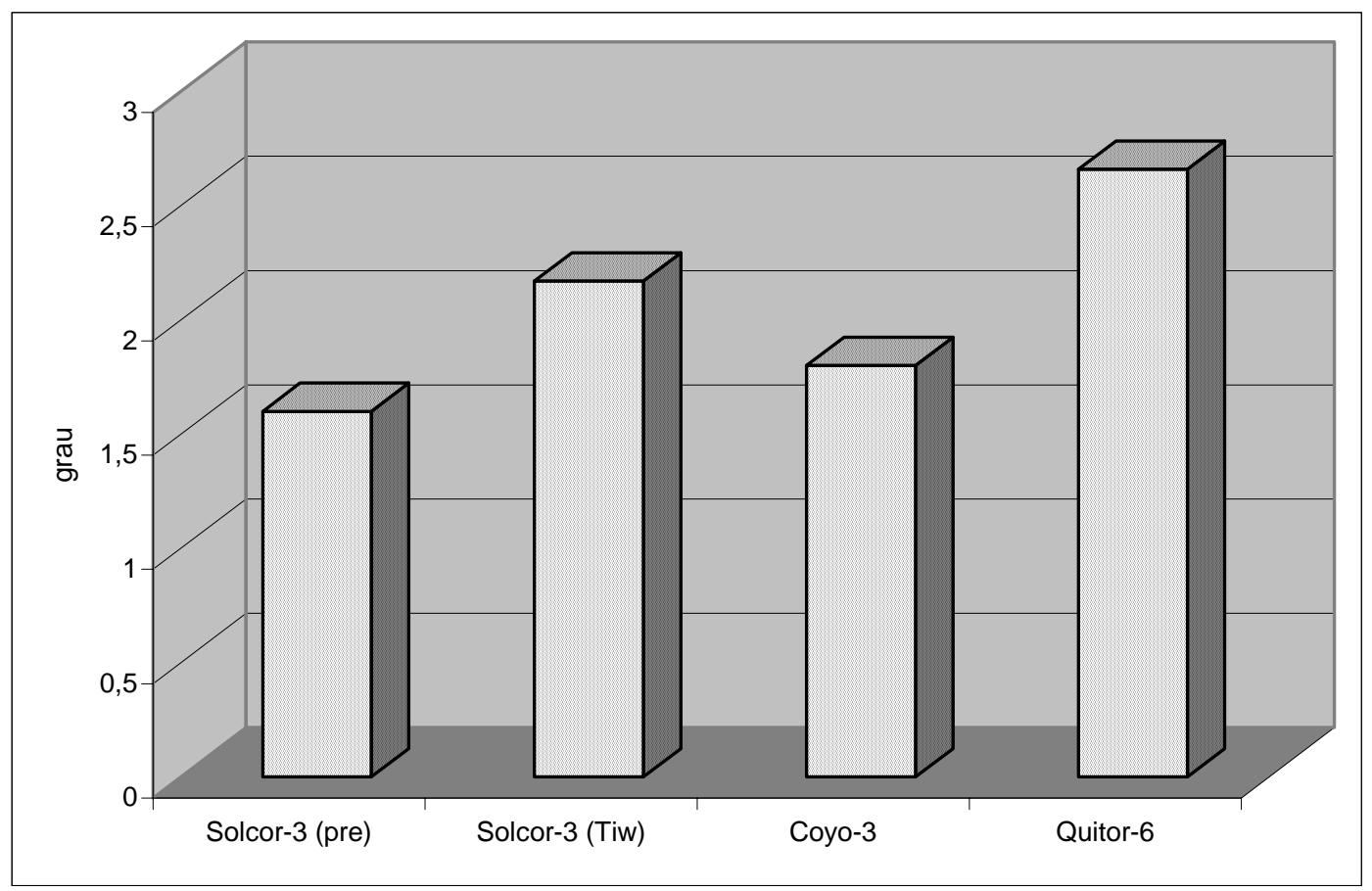

Figura 18 - Média do grau de desgaste dentário usando indivíduo como unidade de análise (dentição decídua) em cada sítio analisado.

Os resultados das freqüências relativas de hipoplasias lineares do esmalte dentário estão na Tabela 19 e Figuras 19 e 20. Os dois tipos de análise (por dente e por indivíduo) apresentaram resultados semelhantes. Quitor-6 apresenta os maiores índices de afetados, seguido por Solcor-3 Tiwanaku; os dois períodos restantes não apresentaram qualquer ocorrência de hipoplasia. O único resultado estatisticamente significativo foi a diferença entre Quitor-6 e Coyo-3 na análise usando dente como unidade (Tabela 20); a análise usando indivíduo como unidade não apresentou resultados estatisticamente significativos (Tabela 21). Os valores corrigidos diminuíram a incidência de afetados em Quitor-6, mas não foram suficientes para alterar a ordem dos períodos, nem a significância dos testes estatísticos (Tabelas 19, 20 e 21, e Figuras 19 e 20). 
Tabela 19 - Freqüência absoluta e porcentagem de dentes e de indivíduos afetados por período analisado; os valores entre parênteses são os resultados corrigidos para o viés idade nas amostras (retirada de um indivíduo em Quitor-6).

\begin{tabular}{lcccc}
\hline & \multicolumn{2}{c}{ hipoplasia (decídua) } & \multicolumn{2}{c}{ hipoplasia (decídua) } \\
por dente & \multicolumn{2}{c}{ por indivíduo } \\
\hline & Frequência & & & \\
& absoluta & porcentagem & frequência absoluta & porcentagem \\
Solcor-3 (pre) & $0 / 65$ & 0,00 & $0 / 15$ & 0,00 \\
Solcor-3 (Tiw) & $1 / 65$ & 1,54 & $1 / 8$ & 12,50 \\
Coyo-3 & $0 / 86$ & 0,00 & $0 / 10$ & 0,00 \\
Quitor-6 & (4) $5 / 65(64)$ & $7,69(6,25)$ & (1) $2 / 7(6)$ & $\mathbf{2 8 , 5 7}(\mathbf{1 6}, 67)$ \\
\hline
\end{tabular}

Tabela 20 - Resultados dos testes Exato de Fisher comparando-se as freqüências de dentes afetados por hipoplasias entre pares de períodos (dentição decídua); os valores em negrito foram considerados significativos $(<5 \%)$.

\begin{tabular}{cccc}
\hline Períodos & Solcor-3 (pre) & Solcor-3 (Tiw) & Coyo-3 \\
\hline Solcor-3 (Tiw) & 1,0000 & $X$ & \\
Coyo-3 & - & 0,4305 & $X$ \\
Quitor-6 * & $0,0577(0,0577)$ & $0,2078(0,2078)$ & $\mathbf{0 , 0 1 3 5}(\mathbf{0 , 0 3 1 4})$ \\
\hline
\end{tabular}

* os valores entre parênteses são os resultados das freqüências corrigidas para o viés idade nas amostras (retirada de um indivíduo em Quitor-6).

Tabela 21 - Resultados dos testes Exato de Fisher comparando-se as freqüências de indivíduos afetados por hipoplasias entre pares de períodos (dentição decídua).

\section{Períodos Solcor-3 (pre) Solcor-3 (Tiw) Coyo-3}

Solcor-3 (Tiw) $\quad 0,3478 \quad x$

Coyo-3 - $\quad 0,4444$

$X$

Quitor-6 * $0,0909(0,2857) \quad 0,5692(1,0000) \quad 0,1544(0,3750)$

* os valores entre parênteses são os resultados das freqüências corrigidas para o viés idade nas amostras (retirada de um indivíduo em Quitor-6). 


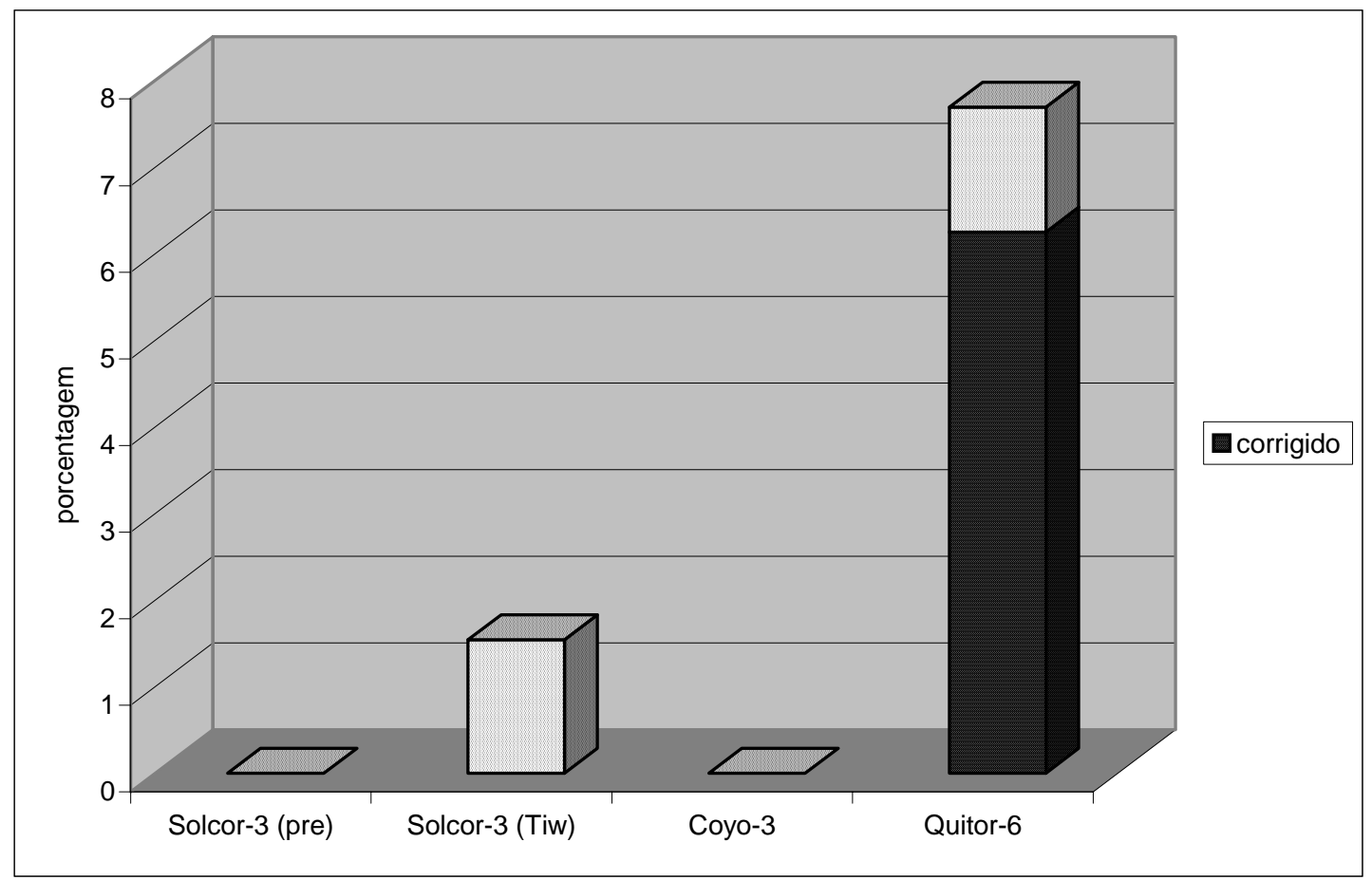

Figura 19 - Porcentagem de dentes afetados por hipoplasias (dentição decídua) em cada sítio analisado; o valor corrigido refere-se ao viés idade nas amostras (retirada de um indivíduo em Quitor-6).

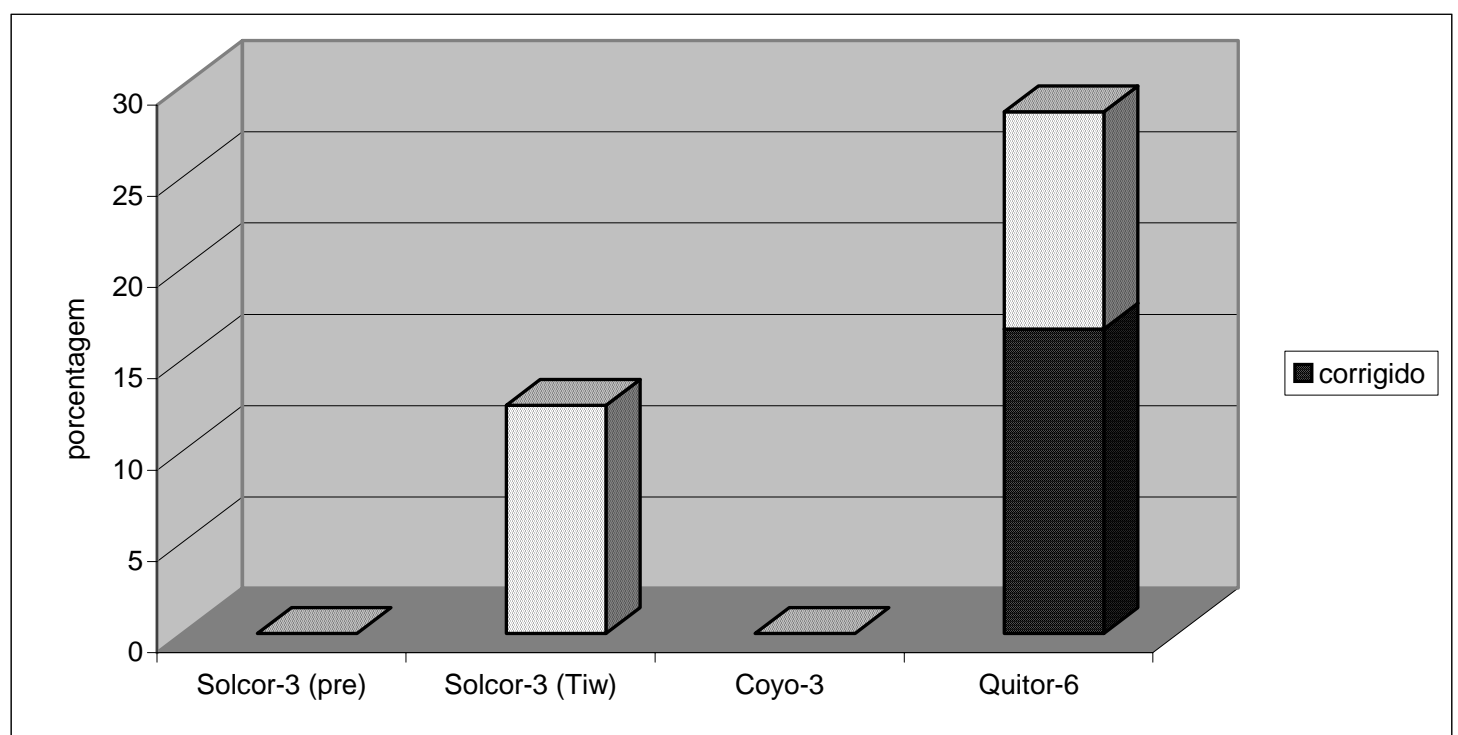

Figura 20 - Porcentagem de indivíduos afetados por hipoplasias (dentição decídua) em cada sítio analisado; o valor corrigido refere-se ao viés idade nas amostras (retirada de um indivíduo em Quitor-6). 
Os resultados das freqüências relativas de hiperostose porótica estão na Tabela 22 e Figuras 21 e 22. A análise usando região anatômica como unidade apresentou Solcor-3 Tiwanaku com o maior índice de afetados, seguido por Coyo-3, Solcor-3 pré-Tiwanaku e Quitor-6. O resultado da análise usando indivíduo como unidade apresentou Coyo-3 com o maior índice de afetados, seguido por Solcor-3 Tiwanaku, Quitor-6 e Solcor-3 préTiwanaku. As freqüências de ambas as análises são muito próximas e o número de afetados é baixo, resultando na ausência de resultados significativos nos testes estatísticos (Tabelas 23 e 24). A correção para o viés representatividade (índice BRI) realizada na análise usando região anatômica como unidade, não alterou a ordem de ocorrência do marcador entre os períodos, fazendo, apenas, diminuir a diferença entre os dois períodos mais afetados e o restante (Tabela 22). O teste estatístico ANOVA não acusou resultado significativo na comparação das médias (em porcentagem) entre os quatro períodos; médias essas obtidas após o cálculo da correção do viés BRI (Tabela 25).

Os resultados das freqüências absolutas de traumas estão na Tabela 26. A freqüência de traumas foi muita baixa nos quatro períodos, restringindo-se a uma ocorrência no sítio Quitor-6. O indivíduo acometido tem quatorze anos de idade e apresentou uma fratura numa costela direita. Tanto a análise utilizando região anatômica como a utilizando indivíduo como unidade não apresentaram resultados estatisticamente significativos (Tabelas 27 e 28).

Os resultados das freqüências absolutas de infecções (total) estão na Tabela 29 e Figuras 23 e 24. Em ambas as análises Solcor-3 Tiwanaku e Quitor-6 apresentaram os maiores índices de afetados, com a diferença que na análise usando região anatômica como unidade o primeiro período apresentou maior freqüência, enquanto na análise usando indivíduo como unidade, o segundo período apresentou maior freqüência. Nas duas análises a terceira maior freqüência é de Solcor-3 pré-Tiwanaku e a quarta é de Coyo-3. As diferenças na análise usando região anatômica como unidade foram estatisticamente significativas, entre períodos sucessivos (Tabela 30). A análise usando indivíduo como unidade não apresentou resultado significativo (Tabela 31). Os resultados da análise de indivíduos afetados estão na Tabela 13 e Figura 25. Solcor-3 Tiwanaku apresentou uma maior extensão (grau) de infecções em indivíduos afetados (média de 17,15\%), enquanto os outros três períodos apresentaram valores mais baixos (em torno de 3 a $7 \%$ ). 
Tabela 22 - Freqüência absoluta e porcentagem de regiões anatômicas e de indivíduos afetados por hiperostose porótica por período analisado; e correção da freqüência de hiperostose porótica para o viés preservação diferencial dos esqueletos (índice BRI); os valores entre parênteses são os resultados corrigidos para o viés idade nas amostras (retirada de um indivíduo em Quitor-6).

\begin{tabular}{lcccccc}
\hline & \multicolumn{2}{c}{$\begin{array}{c}\text { hiperostose porótica } \\
\text { por região anatômica }\end{array}$} & \multicolumn{2}{c}{ hiperostose porótica } & \multicolumn{2}{c}{ hiperostose porótica } \\
& (correção do viés BRI) & \multicolumn{2}{c}{ por indivíduo } \\
\hline & frequência absoluta porcentagem & amostra & porcentagem & frequência absoluta & porcentagem \\
Solcor-3 (pre) & $6 / 76$ & 7,89 & 23 & 8,41 & $3 / 23$ & 13,04 \\
Solcor-3 (Tiw) & $8 / 65$ & 12,31 & 16 & 10,83 & $3 / 16$ & 18,75 \\
Coyo-3 & $6 / 50$ & 12,00 & 14 & 9,52 & $4 / 14$ & 28,57 \\
Quitor-6 & $4 / 65$ & 6,15 & 13 & 6,15 & $2 / 13$ & 15,38 \\
\hline
\end{tabular}

Tabela 23 - Resultados dos testes Exato de Fisher comparando-se as freqüências de regiões anatômicas afetadas por hiperostose porótica entre pares de períodos.

\begin{tabular}{cccc}
\hline Períodos & Solcor-3 (pre) & Solcor-3 (Tiw) & Coyo-3 \\
\hline Solcor-3 (Tiw) & 0,4111 & $\mathrm{X}$ & \\
Coyo-3 & 0,5391 & 1 & $\mathrm{X}$ \\
Quitor-6 & 0,7529 & 0,3642 & 0,3270 \\
\hline
\end{tabular}

Tabela 24 - Resultados dos testes Exato de Fisher comparando-se as freqüências de indivíduos afetados por hiperostose porótica entre pares de períodos.

\begin{tabular}{cccc}
\hline Períodos & Solcor-3 (pre) & Solcor-3 (Tiw) & Coyo-3 \\
\hline Solcor-3 (Tiw) & 0,6743 & $\mathrm{X}$ & \\
Coyo-3 & 0,3895 & 0,6746 & $\mathrm{X}$ \\
Quitor-6 & 1,0000 & 1,0000 & 0,6483 \\
\hline
\end{tabular}


Tabela 25 - Valores dos testes de ANOVA (Kruskal-Wallis) comparando as médias (em porcentagem) entre os períodos analisados para hiperostose porótica e infecções (médias obtidas na correção para o viés preservação diferencial [BRI]), e seus respectivos graus de significância (P).

\begin{tabular}{lcc}
\hline & Kruskal-Wallis & $\mathrm{P}$ \\
\hline Hiperostose porótica & 0,9996 & 0,8014 \\
Infecções (total) & 4,026 & 0,2587 \\
Periostite localizada & 5,935 & 0,1148 \\
Periostite generalizada & 4,435 & 0,2182 \\
Osteomielite localizada & 4,701 & 0,1950 \\
Osteomielite generalizada & 2,349 & 0,5033 \\
\hline
\end{tabular}

Tabela 26 - Freqüência absoluta e porcentagem de dentes e de indivíduos afetados por traumas por período analisado.

\begin{tabular}{lcccc}
\hline & \multicolumn{2}{c}{ traumas } & \multicolumn{2}{c}{ traumas } \\
& por região anatômica & \multicolumn{2}{c}{ por indivíduo } \\
\hline & frequência absoluta & porcentagem & frequência absoluta & porcentagem \\
Solcor-3 (pre) & $\mathbf{0 / 1 9 5 4}$ & $\mathbf{0 , 0 0}$ & $\mathbf{0 / 4 1}$ & $\mathbf{0 , 0 0}$ \\
Solcor-3 (Tiw) & $\mathbf{0 / 1 1 7 4}$ & $\mathbf{0 , 0 0}$ & $\mathbf{0 / 1 7}$ & $\mathbf{0 , 0 0}$ \\
Coyo-3 & $\mathbf{0 / 1 1 1 8}$ & $\mathbf{0 , 0 0}$ & $\mathbf{0 / 1 8}$ & $\mathbf{0 , 0 0}$ \\
Quitor-6 & $\mathbf{1 / 1 3 2 2}$ & $\mathbf{0 , 0 8}$ & $\mathbf{1 / 1 3}$ & $\mathbf{7 , 6 9}$ \\
\hline
\end{tabular}

Tabela 27 - Resultados dos testes Qui-quadrado e dos valores de P comparando-se as freqüências de regiões anatômicas afetadas por traumas entre pares de períodos.

\begin{tabular}{cccc}
\hline Períodos & Solcor-3 (pre) & Solcor-3 (Tiw) & Coyo-3 \\
\hline Solcor-3 (Tiw) & - & $\mathrm{X}$ & \\
Coyo-3 & - & - & $\mathrm{X}$ \\
& & & \\
Quitor-6 & 0,0387 & 0,8884 & 0,8460 \\
& $(\mathrm{P}=8441)$ & $(\mathrm{P}=0,3479)$ & $(\mathrm{P}=0,3577)$ \\
\hline
\end{tabular}


Tabela 28 - Resultados dos testes Exato de Fisher comparando-se as freqüências de indivíduos afetados por traumas entre pares de períodos.

\begin{tabular}{cccc}
\hline Períodos & Solcor-3 (pre) & Solcor-3 (Tiw) & Coyo-3 \\
\hline Solcor-3 (Tiw) & - & $\mathrm{X}$ & \\
Coyo-3 & - & - & $\mathrm{X}$ \\
Quitor-6 & 0,2407 & 0,4333 & 0,4194 \\
\hline
\end{tabular}

Tabela 29 - Freqüência absoluta e porcentagem de regiões anatômicas e de indivíduos afetados por infecções (total) por período analisado; e correção da frequiência de infecção (total) para o viés preservação diferencial (índice BRI).

\begin{tabular}{lcccccc}
\hline & \multicolumn{2}{c}{$\begin{array}{c}\text { infecção (total) } \\
\text { por região anatômica }\end{array}$} & \multicolumn{2}{c}{$\begin{array}{c}\text { infecção (total) } \\
\text { (correção do viés BRI) }\end{array}$} & \multicolumn{2}{c}{$\begin{array}{c}\text { infecção (total) } \\
\text { por indivíduo }\end{array}$} \\
\hline & frequência absoluta & porcentagem & amostra & porcentagem & frequência absoluta & porcentagem \\
Solcor-3 (pre) & $10 / 886$ & 1,13 & 39 & 1,31 & $\mathbf{8} 39$ & $\mathbf{2 0 , 5 1}$ \\
Solcor-3 (Tiw) & $20 / 535$ & 3,74 & 18 & 4,76 & $5 / 18$ & 27,78 \\
Coyo-3 & $2 / 530$ & 0,38 & 18 & 0,42 & $2 / 18$ & 11,11 \\
Quitor-6 & $11 / 545$ & 2,02 & 13 & $\mathbf{2 , 1 6}$ & $\mathbf{5 / 1 3}$ & $\mathbf{3 8 , 4 6}$ \\
\hline
\end{tabular}

Tabela 30 - Resultados dos testes Qui-quadrado e dos valores de P comparando-se as freqüências de regiões anatômicas afetadas por infecções (total) entre pares de períodos; os valores em negrito foram considerados significativos $(<5 \%)$.

\begin{tabular}{cccc}
\hline Períodos & Solcor-3 (pre) & Solcor-3 (Tiw) & Coyo-3 \\
\hline Solcor-3 (Tiw) & 9,766 & & \\
& $(P=\mathbf{0}, 0018)$ & $X$ & \\
Coyo-3 & 1,4230 & 13,251 & \\
& $(P=0,2329)$ & $(P=0,0003)$ & \\
& 1,2830 & 2,281 & 4,761 \\
Quitor-6 & $(P=0,2573)$ & $(P=0,1310)$ & $(P=0,0291)$ \\
\hline
\end{tabular}


Tabela 31 - Resultados dos testes Exato de Fisher comparando-se as freqüências de indivíduos afetados por infecções (total) entre pares de períodos.

\begin{tabular}{cccc}
\hline Períodos & Solcor-3 (pre) & Solcor-3 (Tiw) & Coyo-3 \\
\hline Solcor-3 (Tiw) & 0,7351 & $\mathrm{X}$ & \\
Coyo-3 & 0,4782 & 0,4018 & $\mathrm{X}$ \\
Quitor-6 & 0,2692 & 0,7007 & 0,0994 \\
\hline
\end{tabular}

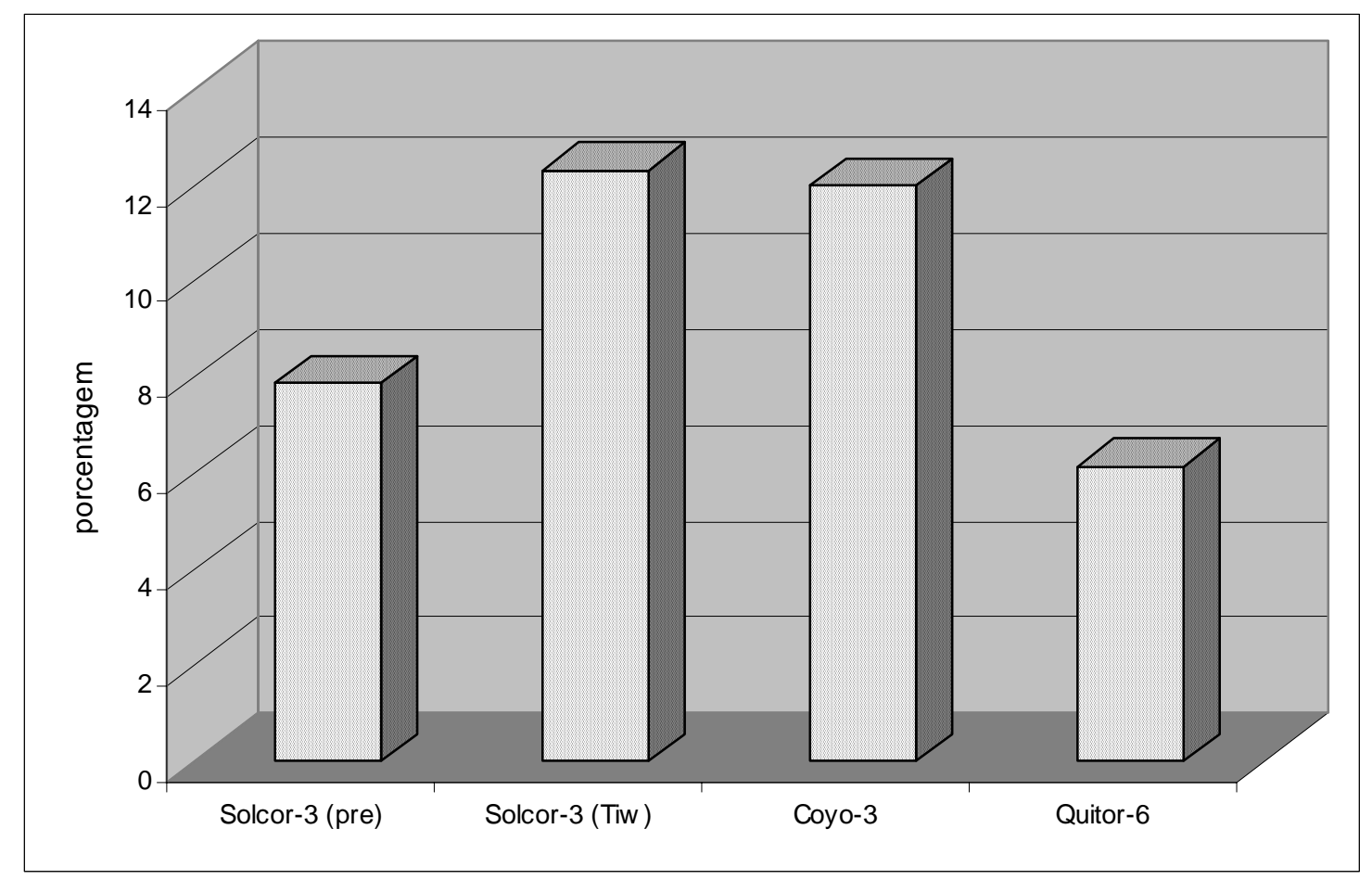

Figura 21 - Porcentagem de regiões anatômicas afetadas por hiperostose porótica em cada sítio analisado. 


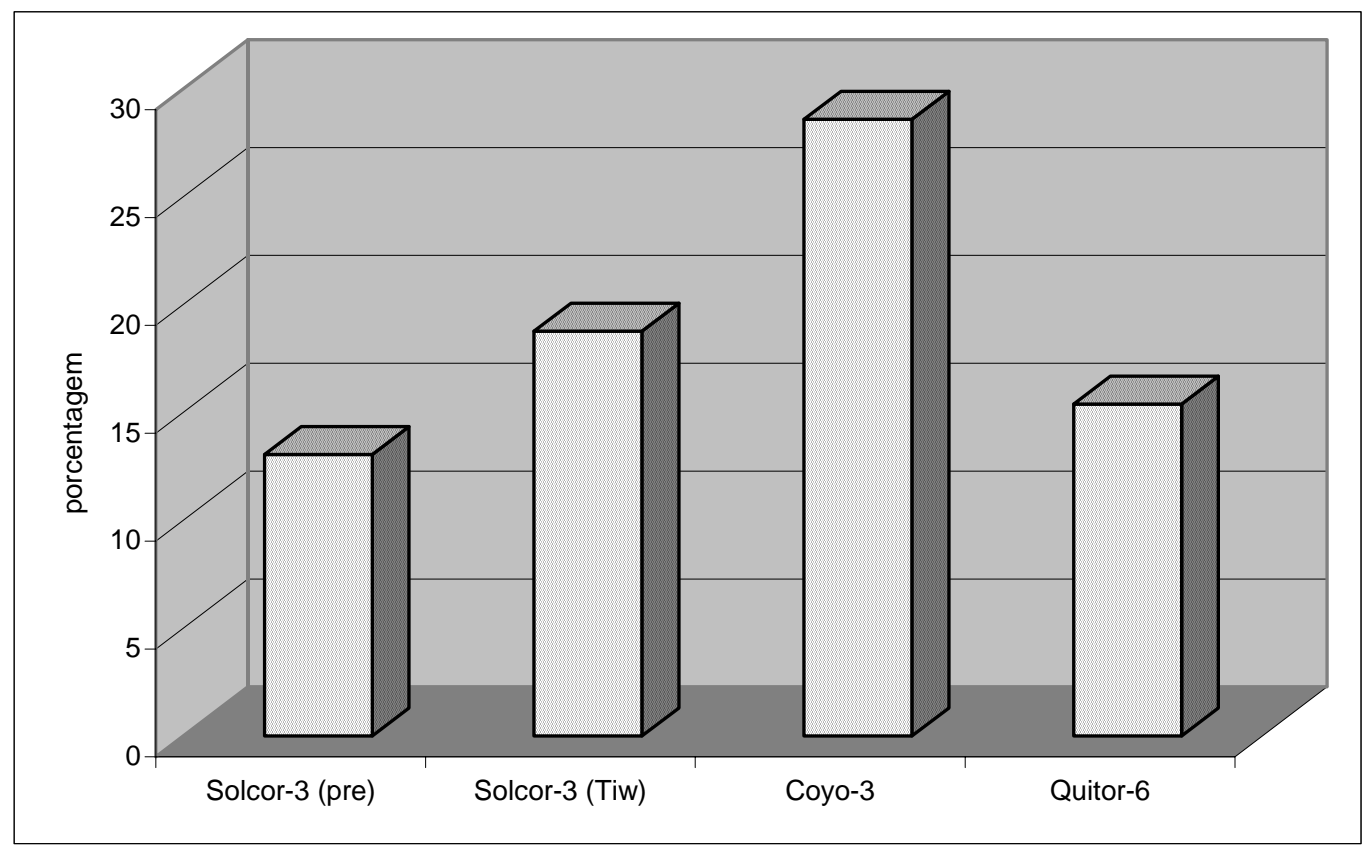

Figura 22 - Porcentagem de indivíduos afetados por hiperostose porótica em cada sítio analisado.

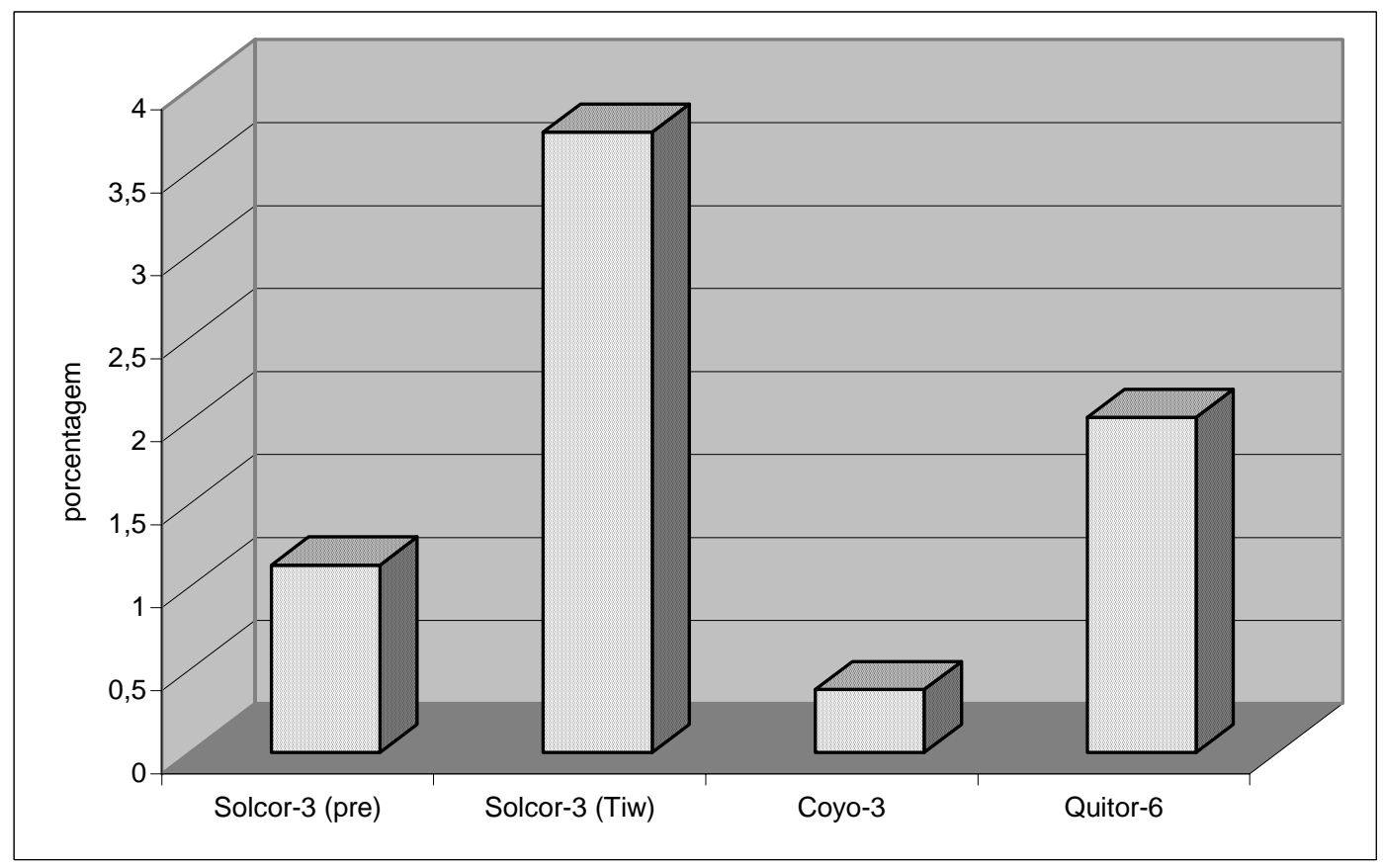

Figura 23 - Porcentagem de regiões anatômicas afetadas por infecções (total) em cada sítio analisado. 


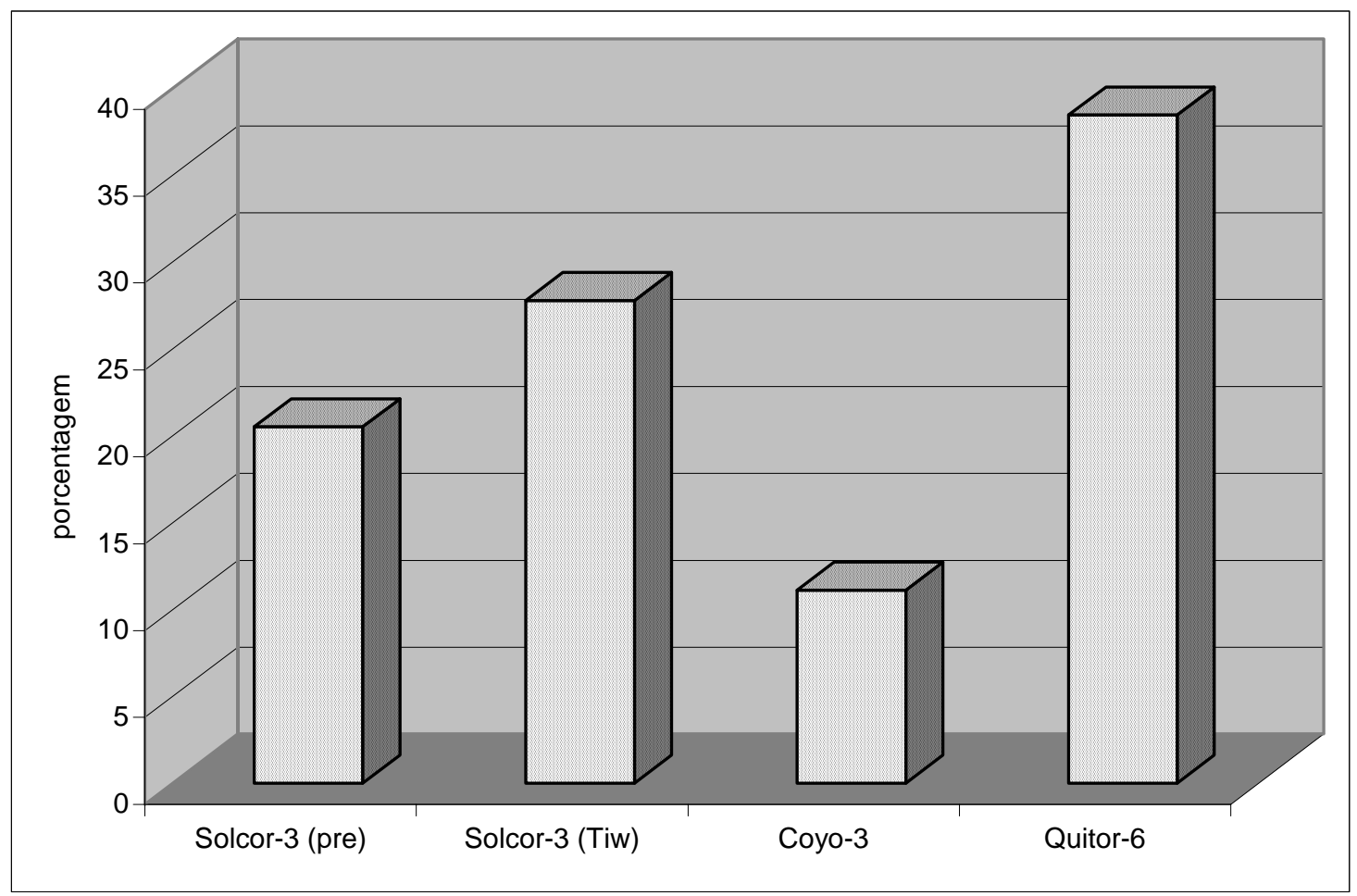

Figura 24 - Porcentagem de indivíduos afetados por infecções (total) em cada sítio analisado.

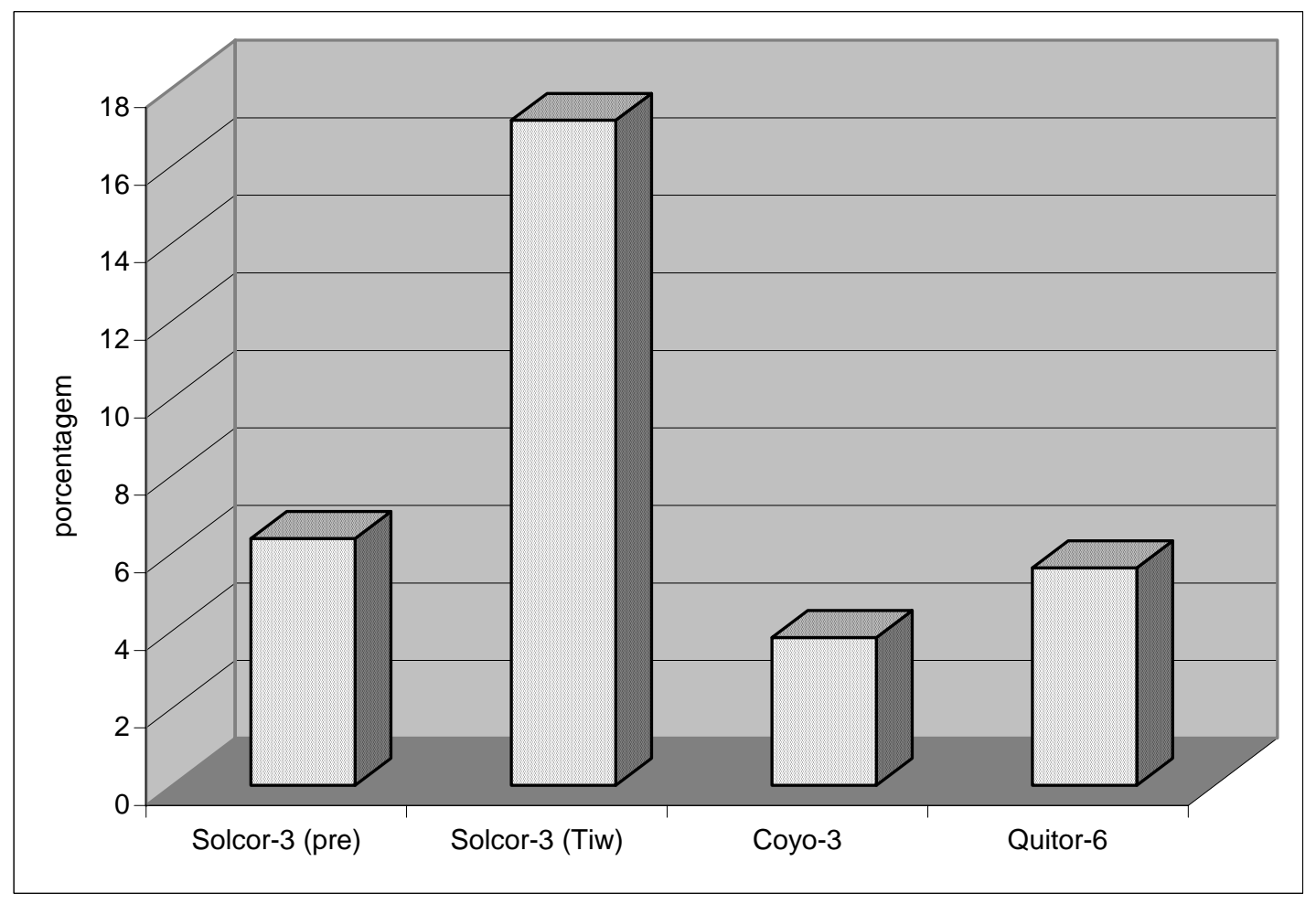

Figura 25 - Média (em porcentagem) de infecções (total) nos indivíduos afetados em cada sítio analisado. 
O teste ANOVA não paramétrico não acusou diferenças significativas entre as médias dos períodos (Tabela 14). A correção dos dados para evitar o viés preservação diferencial (índice BRI) não alterou a ordem de ocorrência do marcador entre os períodos (29). O teste estatístico ANOVA não acusou resultado significativo na comparação das médias calculadas evitando-se o viés do índice BRI (Tabela 25).

Os resultados de infecção foram divididos em periostite localizada e extensa, e osteomielite localizada e extensa; as freqüências relativas estão nas Tabelas 32, 33, 34, 35 e Figuras 26 e 27. Na análise utilizando região anatômica como unidade, Solcor-3 Tiwanaku apresentou a maior freqüência de periostite localizada e osteomielite extensa e a segunda maior nas duas categorias restantes; Quitor-6 apresentou maior freqüência de osteomielite localizada, segunda maior freqüência de periostite localizada, terceira maior frequência de periostite extensa e nenhuma ocorrência de osteomielite extensa. Solcor-3 pré Tiwanaku apresentou segunda maior frequência de osteomielite extensa, terceira de periostite e osteomielite localizada e nenhuma ocorrência de periostite extensa. Coyo-3 apresentou a maior freqüência de periostite extensa e a menor nas três categorias restantes. Na análise usando indivíduo como unidade os resultados são bastante semelhantes: Solcor-3 Tiwanaku apresentou a maior freqüência de periostites e a segunda maior de osteomielites. Quitor-6 apresentou as mesmas ordens da análise usando região anatômica como unidade. Solcor-3 pré Tiwanaku apresentou o maior valor de osteomielite extensa e o restante segue o mesmo padrão da análise usando região anatômica como unidade. Coyo-3 apresenta o mesmo padrão da análise usando região anatômica. $\mathrm{O}$ resultado dos testes estatísticos indicou diferenças significativas somente para periostite localizada e osteomielite extensa (Tabelas 36, 37, 38 e 39). No primeiro marcador, Solcor-3 Tiwanaku apresentou diferença significativa em relação aos valores dos períodos subsequentes; no segundo marcador Solcor-3 Tiwanaku apresentou diferença significativa com os dois períodos seguintes. Na análise usando indivíduo como unidade nenhuma diferença significativa foi detectada pelos testes estatísticos (Tabelas 40, 41, 42 e 43).

Os valores corrigidos para o viés BRI nos quatro tipos de infecção (usando região anatômica como unidade de análise) não alteraram a ordem dos períodos, com exceção do valor de osteomielite localizada, pelo qual Solcor-3 pré Tiwanaku passou da terceira para a 
Tabela 32 - Freqüência absoluta e porcentagem de regiões anatômicas e de indivíduos afetados por periostite localizada por período analisado; e correção da freqüência de periostite localizada para o viés preservação diferencial (índice BRI).

\begin{tabular}{lcccccc}
\hline & \multicolumn{2}{c}{$\begin{array}{c}\text { periostite localizada } \\
\text { por região anatômica }\end{array}$} & \multicolumn{2}{c}{$\begin{array}{c}\text { periostite localizada } \\
\text { (correção do viés BRI) }\end{array}$} & $\begin{array}{c}\text { periostite localizada } \\
\text { por indivíduo }\end{array}$ \\
\hline & frequência absoluta & porcentagem & amostra & Porcentagem & frequência absoluta porcentagem \\
Solcor-3 (pre) & $\mathbf{3 / 8 8 6}$ & $\mathbf{0 , 3 4}$ & $\mathbf{3 9}$ & $\mathbf{0 , 1 9}$ & $\mathbf{3 / 3 9}$ & $\mathbf{7 , 6 9}$ \\
Solcor-3 (Tiw) & $\mathbf{8 / 5 3 5}$ & $\mathbf{1 , 5 0}$ & $\mathbf{1 8}$ & $\mathbf{2 , 4 9}$ & $\mathbf{4 / 1 8}$ & $\mathbf{2 2 , 2 2}$ \\
Coyo-3 & $\mathbf{0 / 5 3 0}$ & $\mathbf{0 , 0 0}$ & $\mathbf{1 8}$ & $\mathbf{0 , 0 0}$ & $\mathbf{0 / 1 8}$ & $\mathbf{0 , 0 0}$ \\
Quitor-6 & $\mathbf{5 / 5 4 5}$ & $\mathbf{0 , 9 2}$ & $\mathbf{1 3}$ & $\mathbf{1 , 1 9}$ & $\mathbf{2 / 1 3}$ & $\mathbf{1 5 , 3 8}$ \\
\hline
\end{tabular}

Tabela 33 - Freqüência absoluta e porcentagem de regiões anatômicas e de indivíduos afetados por periostite extensa por período analisado; e correção da freqüência de periostite extensa para o viés preservação diferencial (índice BRI).

\begin{tabular}{lcccccc}
\hline & \multicolumn{2}{c}{$\begin{array}{c}\text { periostite extensa } \\
\text { por região anatômica }\end{array}$} & \multicolumn{2}{c}{$\begin{array}{c}\text { periostite extensa } \\
\text { (correção do viés BRI) }\end{array}$} & \multicolumn{2}{c}{$\begin{array}{c}\text { periostite extensa } \\
\text { por indivíduo }\end{array}$} \\
\hline & frequência absoluta & porcentagem & amostra & porcentagem & frequência absoluta & porcentagem \\
Solcor-3 (pre) & $\mathbf{0 / 8 8 6}$ & $\mathbf{0 , 0 0}$ & $\mathbf{3 9}$ & $\mathbf{0 , 0 0}$ & $\mathbf{0 / 3 9}$ & $\mathbf{0 , 0 0}$ \\
Solcor-3 (Tiw) & $\mathbf{2 / 5 3 5}$ & $\mathbf{0 , 3 7}$ & $\mathbf{1 8}$ & $\mathbf{0 , 3 5}$ & $\mathbf{2 / 1 8}$ & $\mathbf{1 1 , 1 1}$ \\
Coyo-3 & $\mathbf{2 / 5 3 0}$ & $\mathbf{0 , 3 8}$ & $\mathbf{1 8}$ & $\mathbf{0 , 4 2}$ & $\mathbf{2 / 1 8}$ & $\mathbf{1 1 , 1 1}$ \\
Quitor-6 & $\mathbf{1 / 5 4 5}$ & $\mathbf{0 , 1 8}$ & $\mathbf{1 3}$ & $\mathbf{0 , 1 5}$ & $\mathbf{1 / 1 3}$ & $\mathbf{7 , 6 9}$ \\
\hline
\end{tabular}

Tabela 34 - Freqüência absoluta e porcentagem de regiões anatômicas e de indivíduos afetados por osteomielite localizada por período analisado; e correção da freqüência de osteomielite localizada para o viés preservação diferencial (índice BRI).

\begin{tabular}{lcccccc}
\hline & \multicolumn{2}{c}{$\begin{array}{c}\text { osteomielite localizada } \\
\text { por região anatômica }\end{array}$} & \multicolumn{2}{c}{$\begin{array}{c}\text { osteomielite localizada } \\
\text { (correção do viés BRI) }\end{array}$} & $\begin{array}{r}\text { osteomielite localizada } \\
\text { por indivíduo }\end{array}$ \\
\hline & frequência absoluta & porcentagem & Amostra & Porcentagem & frequência absoluta porcentagem \\
Solcor-3 (pre) & $\mathbf{4 / 8 8 6}$ & $\mathbf{0 , 4 5}$ & $\mathbf{3 9}$ & $\mathbf{0 , 8 1}$ & $\mathbf{4 / 3 9}$ & $\mathbf{1 0 , 2 6}$ \\
Solcor-3 (Tiw) & $\mathbf{4 / 5 3 5}$ & $\mathbf{0 , 7 5}$ & $\mathbf{1 8}$ & $\mathbf{0 , 6 0}$ & $\mathbf{3 / 1 8}$ & $\mathbf{1 6 , 6 7}$ \\
Coyo-3 & $\mathbf{0 / 5 3 0}$ & $\mathbf{0 , 0 0}$ & $\mathbf{1 8}$ & $\mathbf{0 , 0 0}$ & $\mathbf{0 / 1 8}$ & $\mathbf{0 , 0 0}$ \\
Quitor-6 & $\mathbf{5 / 5 4 5}$ & $\mathbf{0 , 9 2}$ & $\mathbf{1 3}$ & $\mathbf{0 , 8 1}$ & $\mathbf{3 / 1 3}$ & $\mathbf{2 3 , 0 8}$ \\
\hline
\end{tabular}


Tabela 35 - Freqüência absoluta e porcentagem de regiões anatômicas e de indivíduos afetados por osteomielite extensa por período analisado; e correção da freqüência de osteomielite extensa para o viés preservação diferencial (índice BRI).

\begin{tabular}{lcccccc}
\hline & \multicolumn{2}{c}{$\begin{array}{c}\text { osteomielite extensa } \\
\text { por região anatômica }\end{array}$} & \multicolumn{2}{c}{$\begin{array}{c}\text { osteomielite extensa } \\
\text { (correção do viés BRI) }\end{array}$} & $\begin{array}{c}\text { osteomielite extensa } \\
\text { por indivíduo }\end{array}$ \\
\hline & frequência absoluta & porcentagem & Amostra & porcentagem & frequência absoluta porcentagem \\
Solcor-3 (pre) & $\mathbf{3 / 8 8 6}$ & $\mathbf{0 , 3 4}$ & $\mathbf{3 9}$ & $\mathbf{0 , 3 0}$ & $\mathbf{3 / 3 9}$ & $\mathbf{7 , 6 9}$ \\
Solcor-3 (Tiw) & $\mathbf{6 / 5 3 5}$ & $\mathbf{1 , 1 2}$ & $\mathbf{1 8}$ & $\mathbf{1 , 3 3}$ & $\mathbf{1 / 1 8}$ & $\mathbf{5 , 5 6}$ \\
Coyo-3 & $\mathbf{0 / 5 3 0}$ & $\mathbf{0 , 0 0}$ & $\mathbf{1 8}$ & $\mathbf{0 , 0 0}$ & $\mathbf{0 / 1 8}$ & $\mathbf{0 , 0 0}$ \\
Quitor-6 & $\mathbf{0 / 5 4 5}$ & $\mathbf{0 , 0 0}$ & $\mathbf{1 3}$ & $\mathbf{0 , 0 0}$ & $\mathbf{0 / 1 3}$ & $\mathbf{0 , 0 0}$ \\
\hline
\end{tabular}

Tabela 36 - Resultados dos testes Qui-quadrado e dos valores de P comparando-se as freqüências de regiões anatômicas afetadas por periostite localizada entre pares de períodos; os valores em negrito foram considerados significativos $(<5 \%)$.

\begin{tabular}{cccc}
\hline Períodos & Solcor-3 (pre) & Solcor-3 (Tiw) & Coyo-3 \\
\hline Solcor-3 (Tiw) & $\begin{array}{c}4,402 \\
(P=\mathbf{0}, \mathbf{0 3 5 9})\end{array}$ & $\mathbf{X}$ & \\
& 0,5534 & 6,105 & \\
Coyo-3 & $(P=0,4569)$ & $(P=\mathbf{0 , 0 1 3 5 )}$ & $\mathbf{X}$ \\
& & & \\
& 1,126 & 0,3501 & 3,104 \\
Quitor-6 & $(P=0,2887)$ & $(P=0,5541)$ & $(P=0,0781)$ \\
\hline
\end{tabular}

Tabela 37 - Resultados dos testes Qui-quadrado e dos valores de P comparando-se as freqüências de regiões anatômicas afetadas por periostite extensa entre pares de períodos.

\begin{tabular}{cccc}
\hline Períodos & Solcor-3 (pre) & Solcor-3 (Tiw) & Coyo-3 \\
\hline Solcor-3 (Tiw) & 1,190 & & \\
& $(P=0,2753)$ & $X$ & \\
Coyo-3 & 1,207 & 0,0001 & $X$ \\
& $(P=0,2719)$ & $(P=0,9925)$ & \\
& 0,0602 & 0,0003 & 0,0006 \\
Quitor-6 & $(P=0,8061)$ & $P=0,9872$ & $(P=0,9807)$ \\
\hline
\end{tabular}


Tabela 38 - Resultados dos testes Qui-quadrado e dos valores de P comparando-se as freqüências de regiões anatômicas afetadas por osteomielite localizada entre pares de períodos.

\begin{tabular}{cccc}
\hline Períodos & Solcor-3 (pre) & Solcor-3 (Tiw) & Coyo-3 \\
\hline Solcor-3 (Tiw) & 0,1275 & & \\
& $(P=0,7210)$ & $X$ & \\
Coyo-3 & 1,064 & 2,230 & \\
& $(P=0,3022)$ & $(P=0,1353)$ & \\
Quitor-6 & 0,5453 & 0,0942 & 3,104 \\
\hline
\end{tabular}

Tabela 39 - Resultados dos testes Qui-quadrado e dos valores de P comparando-se as frequiências de regiões anatômicas afetadas por osteomielite extensa entre pares de períodos; os valores em negrito foram considerados significativos ( $<5 \%)$.

\begin{tabular}{cccc}
\hline Períodos & Solcor-3 (pre) & Solcor-3 (Tiw) & Coyo-3 \\
\hline Solcor-3 (Tiw) & 2,124 & & \\
& $(P=0,1450)$ & $X$ & \\
Coyo-3 & 0,5534 & 4,143 & \\
& $(P=0,4569)$ & $(P=\mathbf{0 , 0 4 1 8 )}$ & $X$ \\
Quitor-6 & 0,5849 & 4,285 & \\
\hline
\end{tabular}

Tabela 40 - Resultados dos testes Exato de Fisher comparando-se as freqüências de indivíduos afetados por periostite localizada entre pares de períodos.

\begin{tabular}{cccc}
\hline Períodos & Solcor-3 (pre) & Solcor-3 (Tiw) & Coyo-3 \\
\hline Solcor-3 (Tiw) & 0,1908 & $\mathrm{X}$ & \\
Coyo-3 & 0,5442 & 0,1039 & $\mathrm{X}$ \\
Quitor-6 & 0,5886 & 1,0000 & 0,1677 \\
\hline
\end{tabular}


Tabela 41 - Resultados dos testes Exato de Fisher comparando-se as freqüências de indivíduos afetados por periostite extensa entre pares de períodos.

\begin{tabular}{cccc}
\hline Períodos & Solcor-3 (pre) & Solcor-3 (Tiw) & Coyo-3 \\
\hline Solcor-3 (Tiw) & 0,0959 & $\mathrm{X}$ & \\
Coyo-3 & 0,0959 & 1,3974 & $\mathrm{X}$ \\
Quitor-6 & 0,2500 & 1,0000 & 1,0000 \\
\hline
\end{tabular}

Tabela 42 - Resultados dos testes Exato de Fisher comparando-se as freqüências de indivíduos afetados por osteomielite localizada entre pares de períodos.

\begin{tabular}{cccc}
\hline Períodos & Solcor-3 (pre) & Solcor-3 (Tiw) & Coyo-3 \\
\hline Solcor-3 (Tiw) & 0,6668 & $\mathrm{X}$ & \\
Coyo-3 & 0,2965 & 0,2286 & $\mathrm{X}$ \\
Quitor-6 & 0,3473 & 0,6758 & 0,0636 \\
\hline
\end{tabular}

Tabela 43 - Resultados dos testes Exato de Fisher comparando-se as freqüências de indivíduos afetados por osteomielite extensa entre pares de períodos.

\begin{tabular}{cccc}
\hline Períodos & Solcor-3 (pré) & Solcor-3 (Tiw) & Coyo-3 \\
\hline Solcor-3 (Tiw) & 1,0000 & $\mathrm{X}$ & \\
Coyo-3 & 0,5442 & 1,0000 & $\mathrm{X}$ \\
Quitor-6 & 0,5641 & 1,0000 & - \\
\hline
\end{tabular}




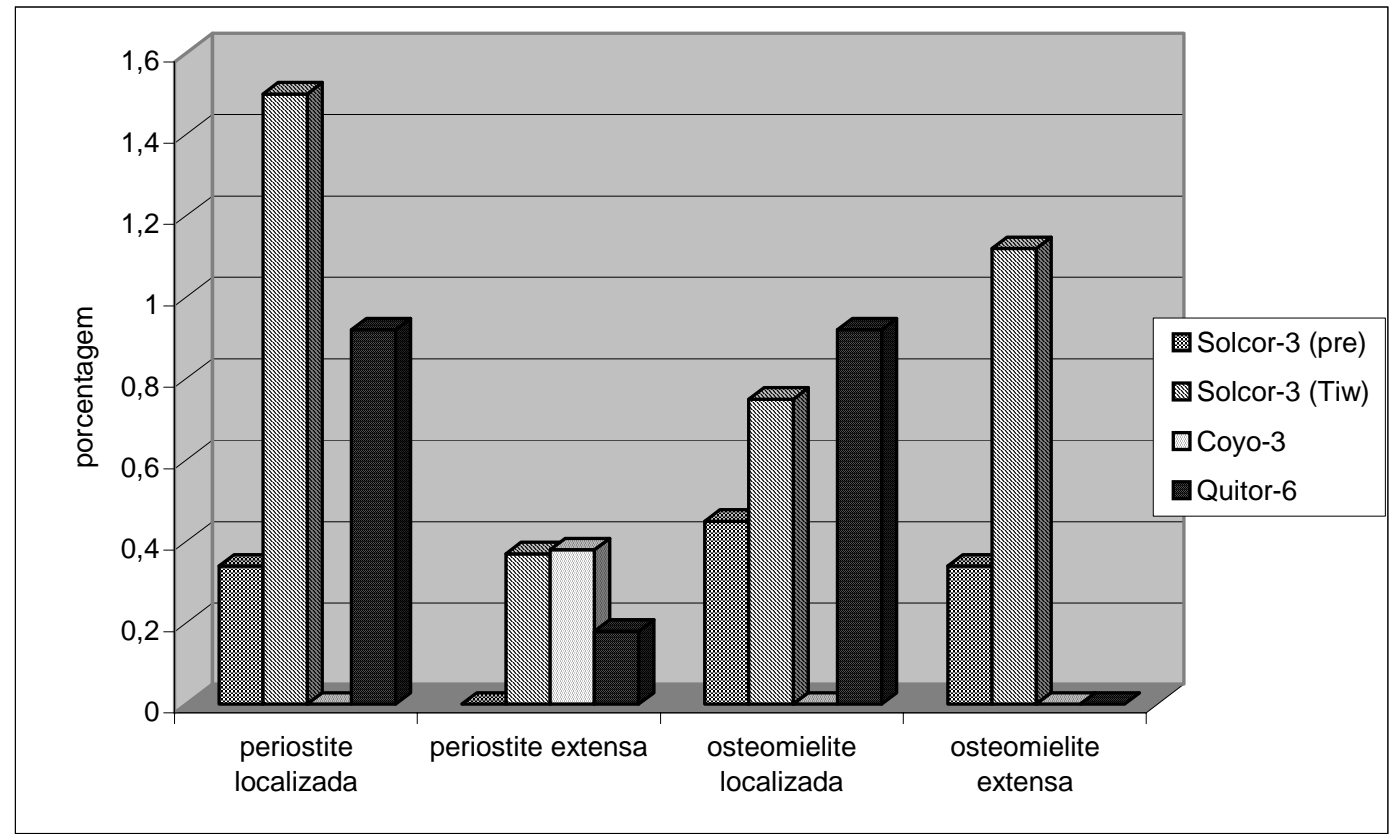

Figura 26 - Porcentagem de regiões anatômicas afetadas pelos quatro tipos de infecções em cada sítio analisado.

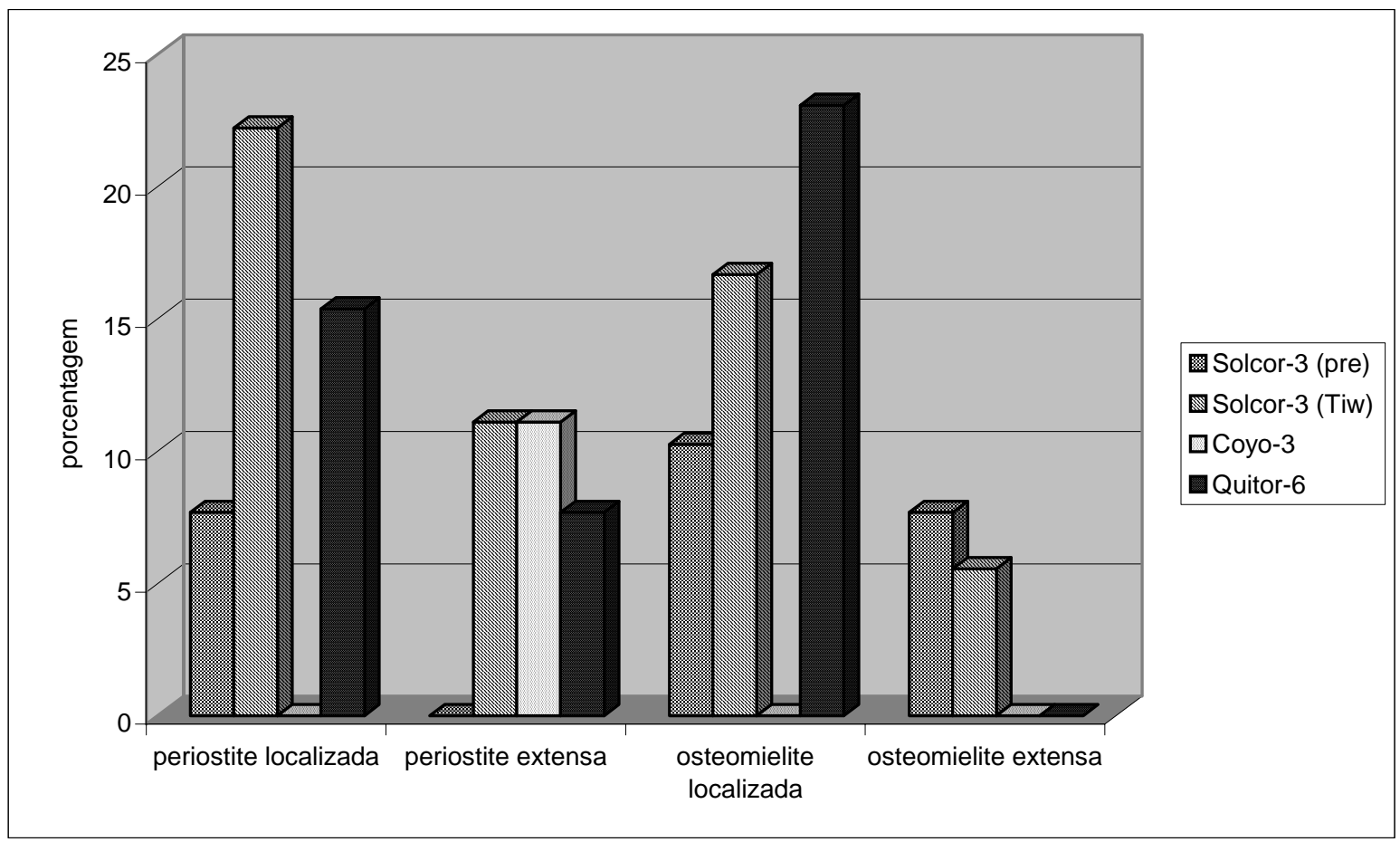

Figura 27 - Porcentagem de indivíduos afetados pelos quatro tipos de infecções em cada sítio analisado. 
maior freqüência de afetados (Tabelas 32, 33, 34, 35). O teste estatístico ANOVA não acusou resultados significativos na comparação das médias calculadas para evitar o viés do índice BRI (Tabela 25).

O resultado da análise da estatura está representado na Tabela 44 e na Figura 28. A figura mostra que os quatro períodos apresentam distribuição de pontos muito semelhante. Os pontos no gráfico se concentram abaixo dos cinco anos de idade, e por esse motivo foi feito um novo gráfico mostrando apenas os indivíduos entre zero e cinco anos (Figura 29). Novamente não há distinção aparente nas variações do comprimento do fêmur ao longo da idade entre os quatro períodos analisados.

A síntese da ocorrência dos marcadores osteológicos nos quatro períodos analisados e os resultados dos testes estatísticos estão apresentados nas Tabelas 45 e 46 . A primeira delas sintetiza a análise usando região anatômica, dente ou alvéolo como unidade de análise, enquanto a segunda sintetiza a análise usando indivíduo como unidade.

\section{3 - Discussão}

\subsection{1 - Amostra}

A preservação de esqueletos nos sítios da região de San Pedro de Atacama é muito boa, disponibilizando uma amostra esqueletal considerável para o estudo dos subadultos. A preservação dos esqueletos, apesar de alta, varia nos três sítios aqui analisados. Quitor-6 apresenta a maior representatividade de ossos e de dentes (índice BRI), enquanto Solcor-3 pré-Tiwanaku apresenta a menor (Tabela 8). Esses valores estão no sentido oposto do número de esqueletos em cada um dos períodos, já que Solcor-3 pré-Tiwanaku apresenta o maior número (41) e Quitor-6 o menor (13).

Essa variação na representatividade (BRI) entre os períodos faz com que a análise utilizando-se indivíduo como unidade no sítio Solcor-3 pré-Tiwanaku seja menos confiável que no sítio Quitor-6, principalmente no que se refere aos marcadores localizados no dente (a mensuração do tamanho desse viés é difícil de calcular). Em contrapartida, a análise utilizando região anatômica, dente ou alvéolo como unidade apresentou tamanhos amostrais mais próximos entre os quatro períodos, já que o período com mais indivíduos é aquele com menor representatividade dos esqueletos (Solcor-3 pré-Tiwanaku). 
Tabela 44 - Dados dos esqueletos subadultos para o marcador estatura em cada um dos períodos analisados

\begin{tabular}{|c|c|c|c|c|c|c|c|}
\hline \multicolumn{2}{|c|}{ Solcor-3 pré-Tiwanaku } & \multicolumn{2}{|c|}{ Solcor-3 Tiwanaku } & \multicolumn{2}{|c|}{ Coyo-3 } & \multicolumn{2}{|c|}{ Quitor-6 } \\
\hline $\begin{array}{l}\text { Idade } \\
\text { (anos) }\end{array}$ & $\begin{array}{l}\text { comprimento } \\
\text { do fêmur } \\
\text { (mm) }\end{array}$ & idade (anos) & $\begin{array}{l}\text { comprimento } \\
\text { do fêmur (mm) }\end{array}$ & $\begin{array}{l}\text { idade } \\
\text { (anos) }\end{array}$ & $\begin{array}{l}\text { comprimento } \\
\text { do fêmur } \\
(\mathrm{mm})\end{array}$ & $\begin{array}{l}\text { idade } \\
\text { (anos) }\end{array}$ & $\begin{array}{l}\text { comprimento } \\
\text { do fêmur } \\
(\mathrm{mm})\end{array}$ \\
\hline 0 & 57 & 0,25 & 67 & 0,085 & 70 & 0,50 & 93 \\
\hline 0 & 73 & 0,5 & 99 & 0,085 & 78 & 0,50 & 90 \\
\hline 0 & 74 & 1 & 120 & 0,25 & 75 & 0,50 & 72 \\
\hline 0,5 & 92 & 1,75 & 145 & 0,5 & 90 & 0,75 & 114 \\
\hline 0,5 & 85 & 2 & 144 & 0,5 & 92 & 0,75 & 112 \\
\hline 0,5 & 79 & 2 & 134 & 0,5 & 93 & 3 & 187 \\
\hline 0,5 & 123 & 2,5 & 133 & 1 & 126 & 3,00 & 164 \\
\hline 0,75 & 106 & 3 & 149 & 2 & 135 & 3,50 & 179 \\
\hline 0,75 & 101 & 3 & 178 & 2,5 & 147 & 4,00 & 154 \\
\hline 1 & 118 & 4 & 135 & 2,5 & 153 & 4,00 & 203 \\
\hline 1,5 & 130 & 4 & 167 & 3 & 156 & 7,00 & 219 \\
\hline 1,5 & 117 & 10 & 232 & 3,5 & 159 & 10,5 & 295 \\
\hline 1,5 & 126 & 17,5 & 393 & 3,5 & 177 & 14 & 338 \\
\hline 2 & 126 & & & 5 & 193 & & \\
\hline 2 & 105 & & & 15 & 323 & & \\
\hline 2,5 & 143 & & & & & & \\
\hline 4 & 124 & & & & & & \\
\hline 7 & 206 & & & & & & \\
\hline 9 & 273 & & & & & & \\
\hline 11 & 256 & & & & & & \\
\hline 12 & 329 & & & & & & \\
\hline 12,5 & 303 & & & & & & \\
\hline 18,5 & 387 & & & & & & \\
\hline
\end{tabular}


Tabela 45 - Síntese da incidência dos marcadores osteológicos usando região anatômica, dente ou alvéolo como unidade de análise, assim como os pares de períodos que apresentaram diferenças significativas $(\mathrm{P}<5 \%)$; o número 1 indica a menor frequência, enquanto o número 4, a maior.

\begin{tabular}{|c|c|c|c|c|c|}
\hline & Solcor-3 pre & Solcor-3 Tiw & Coyo-3 & Quitor-6 & Diferenças significativas \\
\hline Hiperostose porótica & 3 & 4 & 3 & 1 & - \\
\hline Infecção (total) & 2 & 4 & 1 & 3 & $\begin{array}{l}\text { Solcor-3 pre x Solcor-3 Tiw } \\
\text { Solcor-3 Tiw x Coyo-3 } \\
\text { Coyo-3 x Quitor-6 }\end{array}$ \\
\hline Periostite localizada & 2 & 4 & 1 & 3 & $\begin{array}{l}\text { Solcor-3 pre x Solcor-3 Tiw } \\
\text { Solcor-3 Tiw x Coyo-3 }\end{array}$ \\
\hline Periostite extensa & 1 & 3 & 4 & 2 & - \\
\hline Osteomielite localizada * & $2(4)$ & $3(2)$ & 1 & 4 & - \\
\hline Osteomielite extensa & 2 & 3 & 1 & 1 & $\begin{array}{l}\text { Solcor-3 Tiw x Coyo-3 } \\
\text { Solcor-3 Tiw x Quitor-6 }\end{array}$ \\
\hline Traumas & 1 & 1 & 1 & 2 & - \\
\hline Cáries & 3 & 2 & 1 & 4 & $\begin{array}{c}\text { Solcor-3 pre x Coyo-3 } \\
\text { Solcor-3 pre x Quitor-6 } \\
\text { Solcor-3 Tiw x Quitor-6 } \\
\text { Coyo-3 x Quitor-6 }\end{array}$ \\
\hline Abcessos & 2 & 1 & 4 & 3 & - \\
\hline Desgaste dentário & 1 & 3 & 2 & 4 & - \\
\hline Hipoplasias & 1 & 2 & 1 & 3 & Coyo-3 x Quitor-6 \\
\hline
\end{tabular}

* os valores entre parênteses indicam os resultados corrigidos para o viés preservação diferencial (índice BRI). 
Tabela 46 - Síntese da incidência dos marcadores osteológicos usando indivíduo como unidade de análise, assim como os pares de períodos que apresentaram diferenças significativas $(\mathrm{P}<5 \%)$; o número 1 indica a menor frequência, enquanto o número 4 , a maior.

\begin{tabular}{lccccc}
\hline & Solcor-3 pre & Solcor-3 Tiw & Coyo-3 & Quitor-6 & Diferenças significativas \\
\hline Hiperostose porótica & 1 & 3 & 4 & 2 & - \\
Infecção (total) & 2 & 3 & 1 & 4 & - \\
Periostite localizada & 2 & 4 & 1 & 3 & - \\
Periostite extensa * & 1 & 3 & $3(4)$ & 2 & - \\
Osteomielite localizada & 2 & 3 & 1 & 4 & - \\
Osteomielite extensa & 3 & 2 & 1 & 1 & - \\
Traumas & 1 & 1 & 1 & 2 & Solcor-3 pre x Quitor-6 \\
Cáries & 1 & 3 & 2 & 4 & - \\
Abcessos ** & 1 & 2 & 3 & $3(4)$ & Solcor-3 pre x Quitor-6 \\
Desgaste dentário & 1 & 3 & 2 & 4 & - \\
Hipoplasias & 1 & 2 & 1 & 3 & \\
\hline
\end{tabular}

* o valor entre parênteses indica o resultado corrigido para o viés preservação diferencial (índice BRI).

** o valor entre parênteses indica o resultado corrigido para o viés idade nas amostras (retirada de um indivíduo em Quitor-6). 


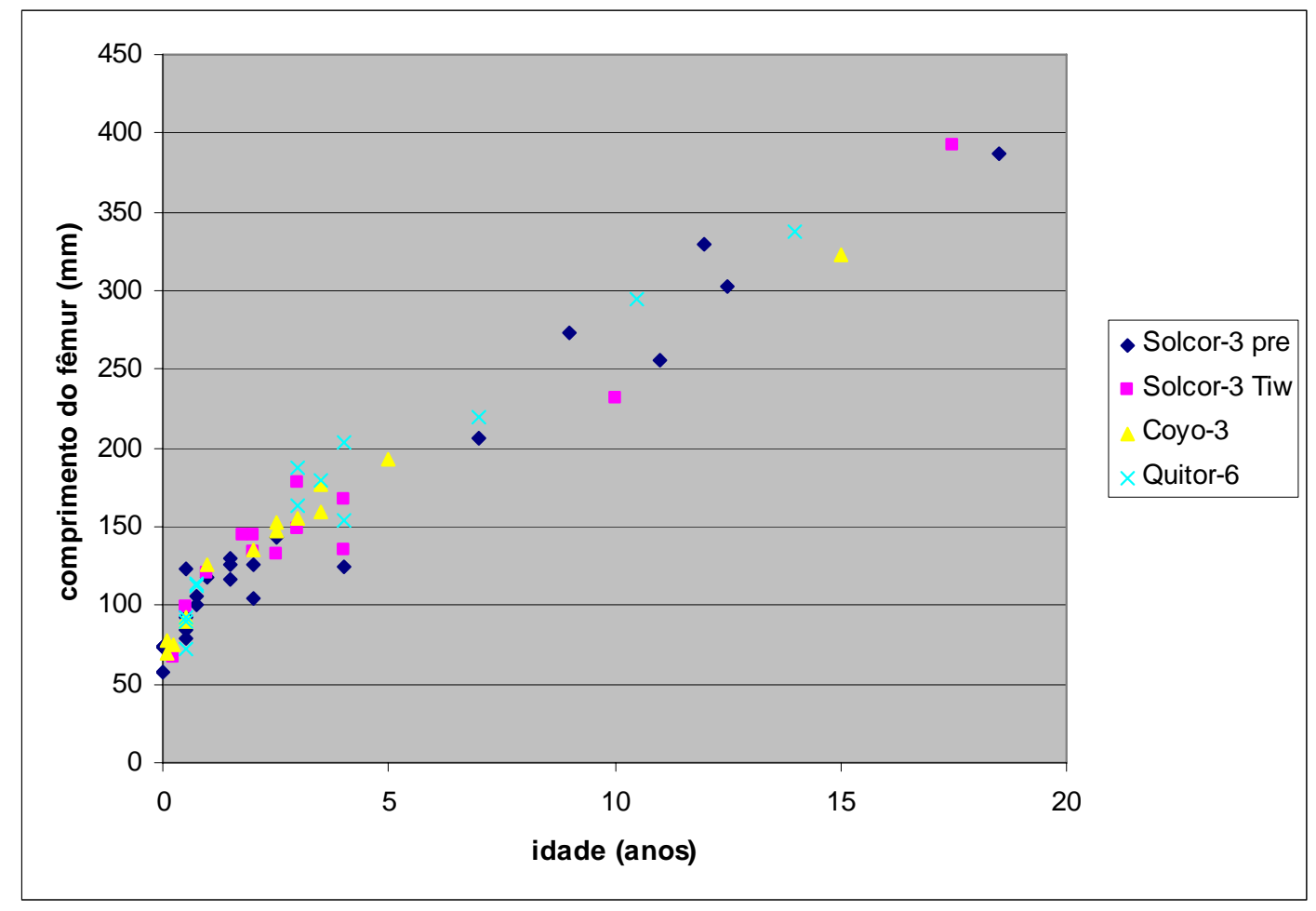

Figura 28 - Gráfico de dispersão dos indivíduos subadultos de San Pedro de Atacama quanto ao comprimento do fêmur nos quatro períodos analisados.

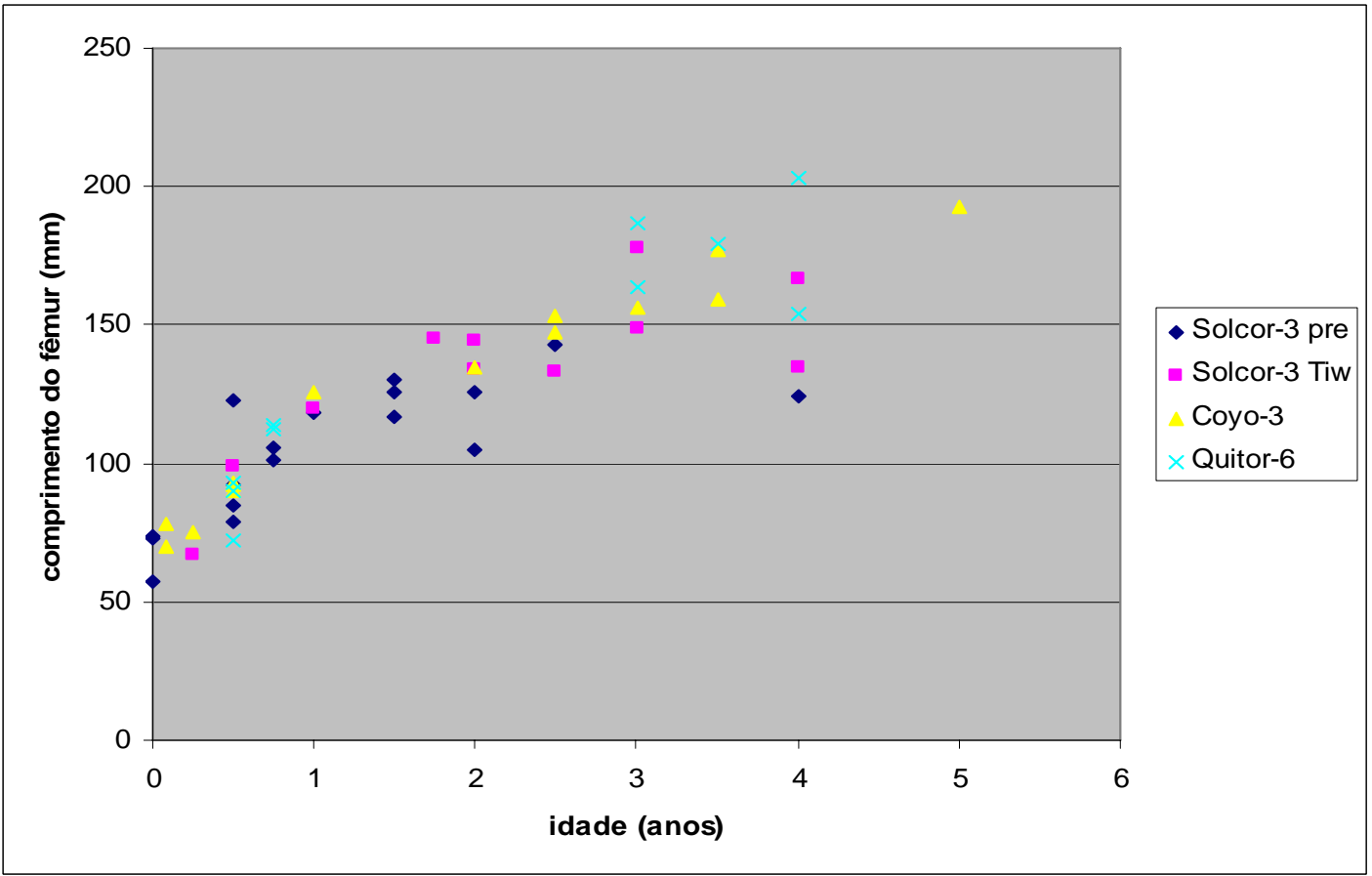

Figura 29 - Gráfico de dispersão dos indivíduos subadultos de San Pedro de Atacama quanto ao comprimento do fêmur nos quatro períodos analisados, destaque para o intervalo entre zero e seis anos. 
O resultado das diversas correções realizadas na amostra não ocasionou grandes mudanças na ordenação dos períodos, nem na significância dos testes estatísticos. Ligeiras alterações na ordem dos períodos para osteomielite localizada (usando região anatômica como unidade), periostite localizada e abcessos (usando indivíduo como unidade) podem ser vistas nas Tabelas 45 e 46. Portanto, é possível concluir que apesar de existir viés na amostra para alguns marcadores, os efeitos nos resultados finais são muito reduzidos.

Segundo Bello et al. (2006) o principal agente da preservação diferencial dos ossos são os fatores intrínsecos (densidade, área e resistência do osso), que são dependentes de idade, sexo e parte anatômica. Os fatores extrínsecos, como profundidade e localização do enterramento, seriam exacerbadores das diferenças intrínsecas dos ossos. Aqueles autores, então, concluem que os processos tafonômicos não são uniformes, eles provocam mudanças proporcionalmente mais intensas em sítios com baixa capacidade de preservação de materiais osteológicos. Os sítios em San Pedro de Atacama mostraram ter boa capacidade de preservação de ossos, de onde se pode concluir que fatores intrínsecos, como a idade de morte do esqueleto, não são tão preponderantes. Um exemplo de sítio com boa preservação de ossos é o Windover Pond, estudado por Stojanowski et al. (2002); o sítio não apresenta qualquer correlação entre grau de preservação e idade dos esqueletos.

A constatação de que as amostras aqui trabalhadas são pouco afetadas pelo viés da distribuição das idades e da representatividade (BRI) não exclui o problema do baixo número amostral em alguns períodos e nem mesmo problemas intrínsecos à amostra esqueletal (Wood et al., 1992). No entanto, foi possível descartar alguns dos possíveis ruídos que afetam a comparação de amostras esqueletais em subadultos.

\subsection{2 - Paradoxo osteológico}

No começo da década de 1990 foi formalizada uma crítica bastante contundente à análise de frequências de marcadores osteológicos de estilo e de qualidade de vida biológica. Formulada por Wood et al. (1992), ela interrompeu o otimismo das análises que imperaram na década de 1980. Chamada de "paradoxo osteológico", a crítica consiste na impossibilidade de saber ao certo se altas freqüências de um marcador deletério no esqueleto são correspondentes à alta incidência dessa lesão na população, ou se, 
inversamente, revelam que os indivíduos com as lesões foram fortes o suficiente para resistirem às doenças dando tempo para que seus esqueletos fossem comprometidos. No primeiro caso, a incidência real do marcador na população viva seria alta, enquanto no segundo ela seria baixa, mas os indivíduos resistiriam mais antes de morrer. Esse tipo de paradoxo foi classificado como intrínseco a qualquer amostra esqueletal (Souza, 1999).

A repercussão do artigo provocou respostas apaixonadas dos defensores dos marcadores osteológicos de qualidade e de estilo de vida (Goodman, 1993; Cohen, 1994, 1995), assim como respostas em apoio às críticas formuladas (Jackes, 1993). Todavia, até o momento não existe uma resposta objetiva para essas críticas. No artigo de Steckel et al. (2002), assim como no livro The Backbone of History como um todo, os autores buscaram solucionar o problema demonstrando que existe uma correlação positiva entre expectativa de vida e índice de qualidade de vida. No entanto, esse tipo de abordagem é apenas uma resposta parcial para o problema.

Outros três artigos elaboram sobre esse mesmo problema. No primeiro deles, Saunders e Hoppa (1993) mostraram que a mortalidade seletiva faz com que indivíduos vivos sejam mais altos que os indivíduos mortos. O viés causado, no entanto, é muito pequeno, sendo superado em importância pelos vieses clássicos da osteologia, como estimativa de idade, tamanho amostral e preservação. No segundo, Bennike et al. (2005), utilizando diversos marcadores, conferiu suporte para a interpretação tradicional dos marcadores osteológicos, uma vez que a série esqueletal com a pior qualidade de vida (indicado pelo contexto histórico e arqueológico) apresentou as maiores incidências dos marcadores. Eles mostraram, ainda, que a divisão dos dados em grupos de idade pode elucidar questões relevantes. Por fim, o trabalho de Sullivan (2005) com cribra orbitalia aprofundou a descrição contextual do sítio, analisando os dados por sexo, status e idade. Essa estratégia seria, segundo a autora, uma forma de solucionar o problema da heterogeneidade escondida (susceptibilidade intra-populacional).

Segundo os autores do paradoxo, é possível solucionar a questão desde que se criem modelos matemáticos que lidem com os subgrupos de uma amostra e suas mortalidades seletivas. O investimento na coleta de dados deveria ser muito maior, a fim de processar essas informações nos modelos, e, então, escapar de uma interpretação simplista das freqüências. Até o momento, pouco se sabe sobre a extensão do paradoxo osteológico para 
cada um dos marcadores, além dos modelos matemáticos propostos ainda não se adequarem à quantidade de informação que é disponível no registro arqueológico.

Em vista desse quadro, foi adotada aqui uma postura clássica para a interpretação dos marcadores osteológicos, ou seja, as freqüências dos marcadores revelam aproximadamente, de forma linear, a qualidade de vida biológica da população. Em suma, quanto maior a incidência do marcador nos esqueletos, mais afetados foram os indivíduos da população.

\subsection{3 - Marcadores dentais (cáries, desgaste dentário, abcessos)}

Esses três marcadores foram agrupados nesta discussão porque estão relacionados diretamente aos efeitos da dieta, além de suas etiologias estarem conectadas. As hipoplasias serão discutidas separadamente porque a causa da lesão é relacionada, principalmente, a estresses sistêmicos e não conseqüência direta do tipo de alimento ingerido (Larsen, 1997; Goodman e Martin, 2002).

O marcador dental cáries apresenta Quitor-6 com a maior incidência e Solcor-3 Tiwanaku e Coyo-3 com as menores (usando dente como unidade de análise). Coyo-3 destaca-se como o sítio com a menor incidência de cáries. Este resultado aponta para as mesmas conclusões alcançadas nos esqueletos adultos: o período sob a influência do Império Tiwanaku apresenta a menor freqüência de cáries (Costa-Junqueira et al., 2004). Uma possível explicação para isto seria o aumento do consumo de proteína animal pela população local durante a influência do Império Tiwanaku. O trânsito de caravanas que passavam por San Pedro de Atacama estariam nas mãos, agora, do Império (Núñez, 1992; Llagostrera, 2004), o que teria propiciado um maior consumo de carne de lhama, pelo deslocamento da função do rebanho local do transporte para a alimentação. Como cárie é um marcador sensível, em grande medida, à quantidade de carboidratos na dieta (TougerDecker and Loveren, 2003), o alto consumo de carne explicaria o decréscimo de sua incidência. Uma intensificação da ingestão de milho também poderia ter brindado a população local com mais proteína. No entanto, nesse caso, teria ocorrido também um aumento acentuado de cáries (Armelagos e Cohen, 1984; Larsen, 1997). Quitor-6 apresenta altas freqüências de cáries, fato que pode estar relacionado à diminuição da oferta de 
proteína animal durante o período. Fatores como fragmentação política, empobrecimento material e uma forte seca (Ortloff e Kolata, 1993; Binford et al., 1997) podem ter confluído para diminuir o número dos rebanhos e das pastagens disponíveis. É importante destacar que quatro pares de períodos acusaram diferenças significativas (Tabela 45).

Os resultados da análise de cáries, usando indivíduo como unidade, apresentaram um padrão bastante semelhante à análise anterior. No entanto, é possível notar que Solcor-3 pré-Tiwanaku apresentou a menor incidência de indivíduos afetados, ao contrário da análise anterior em que apresentava a segunda maior frequência. A análise da incidência apenas nos indivíduos afetados esclarece tal mudança (Tabela 13 e Figura 14). Solcor-3 préTiwanaku apresenta o maior número de cáries nos indivíduos afetados, ou seja, uma vez afetado o indivíduo é severamente comprometido. A interpretação desses resultados é que existem dois grupos na amostra esqueletal de Solcor-3 pré-Tiwanaku: um deles altamente afetado por cáries (8 indivíduos, 40\%) e outro com nenhuma cárie (13 indivíduos, 60\%).

A fim de caracterizar esses dois grupos foi calculada a média da idade dos indivíduos afetados e não afetados. O resultado mostrou uma clara diferença entre eles. Os afetados têm média de 4,31 anos e são compostos por indivíduos iguais ou acima de 2,5 anos. Já os não afetados apresentaram média de 1,77 anos, sendo todos os indivíduos com idade igual ou abaixo de dois anos, à exceção de um indivíduo com dez anos, mas que contribuiu com apenas um dente. Esse quadro sugere fortemente que a partir de 2,5 anos os indivíduos de Solcor-3 pré-Tiwanaku eram acometidos por uma alta incidência de cáries. Essa transição abrupta deve estar ligada à idade do desmame, quando algum alimento bastante cariogênico era introduzido na dieta das crianças (possivelmente baseado no milho). Este mesmo quadro não é encontrado nos outros períodos da pré-história atacamenha. Os sítios Solcor-3 Tiwanaku e Coyo-3 apresentaram uma faixa etária composta por indivíduos afetados e não afetados por cáries (na faixa entre 2 e 3 anos no primeiro e entre 2 e 3,5 no segundo). Tal padrão sugere que nesses dois sítios ocorria uma variabilidade maior na idade do desmame, ou que a inserção de alimentos era mais gradual. No sítio Quitor-6 não foi possível verificar a existência ou não dessa transição, pois todos os indivíduos têm três anos ou mais (e todos apresentaram cáries). Apesar das variações, é ponto comum que nos quatro períodos as cáries só começaram a aparecer a partir dos dois anos de idade (ver Capítulo 5). 
A fim de testar se esses dois grupos de idade em Solcor-3 pré-Tiwanaku seriam também encontrados em outros marcadores, foi feito um acompanhamento detalhado dos oito indivíduos afetados no restante das análises. O resultado mostrou que somente três dos oito indivíduos foram afetados por abcessos e infecções, enquanto somente um é afetado por hiperostose porótica. Os marcadores infecções e hiperostose porótica apresentaram outros indivíduos afetados que não faziam parte dos oito acompanhados, enquanto para abcessos os únicos três afetados faziam parte dos oito. Esse quadro indica que a distinção entre esses dois grupos de idade é uma característica exclusiva desse marcador - forte relação de cáries com idade nos primeiros três anos de vida - e desse sítio - transição rápida do desmame.

A interpretação do marcador desgaste dentário foi feita a partir da análise que usou indivíduo como unidade. Isso ocorreu porque a correção do viés representatividade (índice BRI) apontou esta direção como a mais confiável. De qualquer maneira, os resultados de ambas as análises são bastante semelhantes.

Os resultados desse marcador apontaram para uma progressão de Solcor-3 préTiwanaku para Quitor-6. Essa tendência é rompida por uma ligeira diminuição do desgaste em Coyo-3. O teste estatístico ANOVA (Kruskall-Wallis) acusou diferença significativa entre os períodos, e o pós-teste de Dunn acusou diferença entre os valores extremos (Solcor-3 pré-Tiwanaku e Quitor-6). Nos adultos não foi possível verificar essa mesma progressão (Costa-Junqueira et al., 2004). A explicação para essa tendência não é simples. Quando os dados de desgaste dentário de adultos foram separados em leve (1-3), médio (46) e extremo (7- 8) na escala de Molnar (1971), os resultados apontaram para o período sob influência do Império Tiwanaku como o menos afetado (Neves et al., 2000). Esse resultado, novamente, não é compatível com os dos subadultos. As explicações para as médias de desgaste dos subadultos estariam relacionadas ao modo de preparo, consistência do alimento e período de desmame. Porém, ainda não existem dados para sabermos ao certo quais e como esses fatores influenciaram no desgaste. Em suma, a influência do Império Tiwanaku parece não ter sido impactante na variação temporal do desgaste dentário entre os subadultos de San Pedro de Atacama.

O marcador dental abcesso não apresentou resultado significativo nos testes estatísticos comparativos, possivelmente devido ao baixo número de indivíduos e alvéolos 
afetados. Apesar de não significativos, é possível distinguir dois blocos diferenciados de resultados: Solcor-3 pré e Tiwanaku por um lado, e Coyo-3 e Quitor-6 por outro. O primeiro apresentou as menores frequências e o segundo, as maiores. Houve variação na ordem de afecção dos períodos entre a análise usando alvéolo e a usando indivíduo como unidade, porém os dois grupos se mantiveram. Esse padrão não se enquadra na expectativa de que o Império Tiwanaku influenciou positivamente a qualidade de vida biológica local. Observando-se apenas os alvéolos afetados tal hipótese poderia ser confirmada, mas ao se observar indivíduos afetados, não.

Os abcessos são, geralmente, o resultado de um alto índice de cáries e/ou um alto índice de desgaste dentário (Larsen, 1997). Isso explica a alta frequência de abcessos em Quitor-6 e a baixa em Solcor-3 pre e Tiwanaku. Coyo-3, todavia, parece não apresentar uma razão clara para o aumento desse marcador. O baixo número encontrado de afetados por abcessos, em geral, é um fator que diminui a confiabilidade das tendências aqui apresentadas.

Em síntese, os marcadores dentais parecem apontar direções um tanto confusas quando comparados entre si. Cáries é o único marcador que corrobora a hipótese de que a influência do Império Tiwanaku melhorou a qualidade de vida biológica da população atacamenha. Abcessos, usando alvéolo como unidade, parecem apontar para esta mesma direção. Por outro lado, as análises usando indivíduo como unidade, revelam uma tendência progressiva de incidência do marcador. A alta incidência dos marcadores em Quitor-6 seria resultado de fragmentação política, empobrecimento material e uma forte seca, que acabou afetando a população atacamenha como um todo. O desgaste dentário não corroborou a hipótese inicial deste trabalho.

\subsection{4 - Hipoplasias lineares do esmalte dentário}

Hipoplasias resultam, principalmente, de estresses sistêmicos no momento da formação do dente (Hillson, 1996; Larsen, 1997). A idade de formação do esmalte na dentição decídua é entre 5 meses de gestação até 9 meses de vida (Buikstra e Ubelaker, 1994). Nesse período fatores como infecção e nutrição podem causar estresse. A nutrição da mãe é um fator decisivo para o bebê, já que é ela quem transmite ao filho os nutrientes 
necessários durante a gestação e a amamentação. O período de desmame é um outro fator importante (Katzenberg et al., 1996), porém não existem dados sobre tal comportamento para San Pedro de Atacama. Se fiarmos na análise de cáries (ver acima) para definir a idade de desmame, ela não ocorreria abaixo dos dois anos de idade.

As hipoplasias foram encontradas em apenas dois períodos: Solcor-3 Tiwanaku e Quitor-6. Não causa surpresa o fato de Quitor-6 apresentar a maior incidência de dentes e de indivíduos afetados, já que, como foi visto nos demais marcadores dentais, o período apresenta os piores índices de qualidade de vida biológica na região. A relativamente alta incidência de hipoplasias em Solcor-3 Tiwanaku não confirma a hipótese esperada neste trabalho. A possível causa desse resultado é a alta incidência de infecções (ver tópico Infecções). O resultado dos subadultos parece apresentar a mesma tendência dos esqueletos adultos (Costa-Junqueira et al., 2004), ambos apresentando diferença significativa somente entre Coyo-3 e Quitor-6.

\subsection{5 - Infecções inespecíficas}

As infecções (total) fizeram de Solcor-3 Tiwanaku e Quitor-6 os períodos com maior incidência de afetados (o primeiro período na análise usando região anatômica como unidade e o segundo período na análise usando indivíduo). Assim como nos marcadores analisados anteriormente, Quitor-6 destacou-se pela baixa qualidade de vida biológica, principalmente ao considerarmos a grande quantidade de indivíduos afetados nesse período. Coyo-3 apresentou as menores freqüências de infecções (total), seguido por Solcor-3 pré-Tiwanaku. Esse resultado é muito semelhante ao que foi encontrado nos esqueletos adultos (Glória et al., submetido).

O resultado das quatro subdivisões das infecções mostra um resultado semelhante ao das infecções (total). Periostite localizada é a que mais corresponde a esse padrão; como é a lesão mais comum, acaba influenciando os resultados de infecções (total). Já os valores de osteomielite extensa apontaram para Solcor-3 pré-Tiwanaku e Tiwanaku como os períodos com as lesões mais graves. Esse resultado revela que Solcor-3 Tiwanaku, além de apresentar altas incidências de infecções, apresenta também as lesões mais graves. 
A análise de indivíduos afetados para o marcador infecções (total) corrobora a idéia de que Solcor-3 Tiwanaku é o período com maior índice de infecções. Uma vez que o indivíduo é afetado, a extensão da infecção no esqueleto é maior que no restante dos períodos. Este resultado, no entanto, não é significativo, já que o número amostral é baixo.

A partir desses dados é possível afirmar que Solcor-3 Tiwanaku apresenta os maiores índices de infecção. Tal resultado não corrobora a hipótese inicial deste trabalho, mas, em contrapartida, corrobora a idéia de que nesse período a densidade populacional aumentou consideravelmente em San Pedro de Atacama (Llagostera e Costa, 1999). As causas de infecções, em geral, estão ligadas tanto ao aumento de densidade, como a um maior trânsito de pessoas; ambos os fatores estavam presentes no auge da influência do Império Tiwanaku (Llagostera, 2004).

\subsection{6 - Hiperostose porótica}

Os resultados do marcador hiperostose porótica indicam o sítio Solcor-3 Tiwanaku e Coyo-3 como os períodos que apresentaram a maior freqüência. É importante ressaltar que a diferença entre os períodos não é estatisticamente significativa, possivelmente devido à baixa incidência desse marcador em San Pedro de Atacama.

Os fatores que influenciam o marcador hiperostose porótica são múltiplos, indo de infecções até nutrição e parasitismo (Holland e O’Brien, 1997). Locais muito secos tendem a ter baixos índices de hiperostose porótica devido à uma menor sobrevivência de parasitas (Blom et al., 2005). Tal característica pode explicar a baixa freqüência de hiperostose porótica em Quitor-6, já que durante esse período houve uma forte seca em escala regional nos Andes (Ortloff e Kolata, 1993; Binford et al., 1997). Este resultado é oposto ao restante dos marcadores, que apresentaram Quitor-6 como o sítio com pior qualidade de vida biológica. A alta incidência no sítio Solcor-3 Tiwanaku pode estar relacionada a uma alta densidade populacional ou mesmo à construção de sistemas de irrigação nessa época. Ambos os fatores favorecem a proliferação de parasitas e o aumento de infecções em uma população (Kent, 1986; Blom et al., 2005). Entretanto, Coyo-3 apresenta baixo índice de infecções.

A tendência dos esqueletos subadultos é parcialmente semelhante aos adultos. Os resultados dos adultos (Costa-Junqueira et al., 2004) e dos subadultos apontam para Solcor- 
3 Tiwanaku como o período com maior incidência de hiperostese porótica (resultados estatisticamente não significativos). Coyo-3, todavia, apresenta incidência mais baixa nos adultos do que nos subadultos.

\subsection{7 - Traumas}

A incidência de traumas nos subadultos de San Pedro de Atacama é praticamente zero. O único indivíduo afetado é do sítio Quitor-6, com uma fratura de costela. Violência inter pessoal, inclusive abuso parental, e acidentes domésticos deviam ser, portanto, praticamente inexistentes na infância em San Pedro de Atacama, já que o único indivíduo afetado apresenta 14 anos de idade.

\subsection{8 - Estatura}

Assumindo que as populações pré-históricas de San Pedro de Atacama analisadas aqui são geneticamente semelhantes (Costa-Junqueira et al., 1995; Llagostera, 2004), as possíveis variações na estatura resultam necessariamente de fatores ambientais (nutrição e infecções). Os resultados, porém, não mostraram diferenças nítidas quanto ao comprimento do fêmur entre os períodos analisados, lembrando que os dados se concentram principalmente nos esqueletos abaixo de cinco anos.

O resultado dos subadultos é contraditório aos gerados a partir dos esqueletos adultos. Segundo Neves e Costa (1998), o sítio Solcor-3 Tiwanaku apresentou fêmures maiores que o restante dos períodos para adultos, embasando a hipótese de melhoria da qualidade de vida biológica local durante a influência do Império Tiwanaku. A necessidade de uma explicação para essa contradição fica mais explícita quando constata-se que o sítio Quitor-6, que apresentou os piores índice de qualidade de vida biológica nos outros marcadores, não apresenta nenhuma diferença quanto ao comprimento de fémur em relação ao restante dos períodos em San Pedro de Atacama. O que pode ser aventado, então, para explicar a contradição nos dados de adultos e de subadultos é que a diferença na estatura final (adultos) entre os períodos foi gerada entre cinco e dezoito anos, o período menos representado neste trabalho. Uma outra possibilidade seria a existência de uma diferença 
gradual em todas as faixas etárias, porém não o suficiente para produzir, no gráfico, uma distinção nítida entre os períodos.

\section{4 - Síntese}

Os resultados apresentados não confirmam a hipótese inicial deste trabalho de que a influência do Império Tiwanaku melhorou a qualidade de vida biológica da população atacamenha, à exceção do marcador cáries. Os demais marcadores apresentaram um quadro bastante variado, revelando a existência de outros fatores determinantes. As principais conclusões estão sintetizadas a seguir:

1) O sítio Solcor-3 pré-Tiwanaku apresentou freqüências que oscilaram entre as mais baixas e as de posição intermediária em relação aos outros períodos. A análise de cáries revelou a existência de dois grupos distintos dependentes da idade: um deles bastante afetado (mais velho) e o outro não afetado (mais jovem). Não foi encontrada a formação desses mesmos grupos com outros marcadores.

2) O sítio Solcor-3 Tiwanaku apresentou alta freqüência de infecções e hiperostose porótica, porém baixo índice de cáries. O restante dos marcadores oscilou numa posição intermediária em relação aos outros períodos. À exceção de cáries, os marcadores não corroboraram a hipótese inicial deste trabalho.

3) O sítio Coyo-3 apresenta um padrão bastante variado. Infecções, cáries e hipoplasias apresentam baixa incidência, ao passo que hiperostose porótica e abcessos apresentam alta incidência. Corresponderiam essas características a um sítio de transição entre períodos?

4) O sítio Quitor-6 apresenta os piores índices de qualidade de vida biológica, à exceção de hiperostose porótica. Esses dados refletem um período de fragmentação política, de empobrecimento material e de forte seca (Llagostera, 2004), que atingiu toda a região do Salar de Atacama. 


\section{Capítulo 5 - Análise Mundial}

\section{1 - Material e métodos}

Este capítulo usou a mesma amostra do capítulo anterior. A amostra é constituída por 90 esqueletos de subadultos de San Pedro de Atacama (menores de 20 anos), dos quais 59 apresentam dentição, e é datada de 250 A.D. até 1240 A.D (ver Capítulo 4).

A análise mundial consistiu na caracterização dos marcadores osteológicos da população atacamenha como um todo, agrupando os esqueletos dos três sítios em uma única amostra. Os esqueletos, nesta abordagem, inserem-se num período de 990 anos, durante os quais a subsistência foi marcada pelo cultivo e pelo pastoreio.

O primeiro procedimento consistiu na distinção entre indivíduos afetados e não afetados para cada um dos marcadores osteológicos. O indivíduo foi considerado afetado se ao menos uma região do esqueleto apresentasse o marcador. Em seguida, os indivíduos foram divididos em oito faixas etárias (em anos): 0-0,9; 1-1,9; 2-2,9; 3-3,9; 4-4,9; 5-9,9; 10-14,9; 15-19,9. Para cada uma destas faixas etárias foi calculada a porcentagem de indivíduos afetados para cada marcador. As faixas etárias foram estabelecidas com diferentes intervalos devido ao fato de existirem mais esqueletos até os cinco anos do que entre 5 e 20 anos. Adotando tal procedimento, os testes estatísticos tornaram-se mais sensíveis.

Dados referentes à hipoplasia não foram divididos por faixa etária, porque suas marcas típicas acontecem apenas durante a formação do esmalte. Uma vez formado, o esmalte não se remodela durante toda a vida do indivíduo. A maneira mais correta de analisar cronologicamente a incidência de hipoplasias em San Pedro de Atacama seria através da medição da distância da hipoplasia em relação à junção esmalte-cemento do dente a fim de obter a idade de formação no indivíduo; esses dados, no entanto, não foram coletados nos esqueletos subadultos de San Pedro por Walter Neves e Maria Antonietta Costa.

O segundo procedimento foi a comparação das freqüências de indivíduos afetados de San Pedro de Atacama com outras populações mundiais. Esta análise dependeu do tipo 
de dados encontrados na literatura para cada um dos marcadores osteológicos empregados. Há uma variabilidade muito grande nos critérios diagnósticos utilizados por diferentes autores, o que implica uma grande limitação na comparação de dados. A comparação também depende da disponibilização, nos artigos, de tabelas que apresentem o número amostral e a freqüência de afetados, ao invés de representações unicamente gráficas, motivo pelo qual não foi realizada a análise global para desgaste dentário. A abordagem empregada aqui é uma primeira aproximação aos dados mundiais, sem preocupações excessivas com nuances metodológicas e utilizando categorias de análise bastante amplas.

O levantamento bibliográfico foi realizado conforme a disponibilidade dos periódicos pertinentes nas bibliotecas da USP e na rede. A principal fonte de dados foi o American Journal of Physical Anthropology, revista internacional conceituada, com inúmeras publicações sobre marcadores osteológicos. O livro Backbone of History de Richard Steckel e Jeromy Rose também foi uma fonte valiosa de dados comparativos.

As comparações foram realizadas preferencialmente com dados de subadultos. Porém, este tipo de dado é bastante raro na literatura, resumindo-se a uma pequena quantidade de informações disponíveis (o que impediu uma abordagem estatística). Desta forma a comparação estatística foi feita utilizando-se, basicamente, dados de adultos (com exceção de hiperostose porótica). A comparação de dados de subadultos com adultos tem algumas restrições (Wood et al., 1992); no entanto, para a maioria dos marcadores, representa a única possibilidade sólida de comparação entre populações.

A característica chave observada nas amostras mundiais foi a estratégia de subsistência dos grupos, já que este é um fator determinante do estilo de vida das populações pretéritas. Os dados das populações mundiais foram agrupados pelo tipo de subsistência: caça-coleta, pesca-caça-coleta, mista (entre caça-coleta e agricultura), agricultura e pastoralismo. Além dessas categorias baseadas em subsistência, duas outras, de cunho estritamente social, foram também incorporadas: escravos e urbanizados Os horticultores foram incluídos entre os agricultores nos testes estátisticos, devido à fronteira tênue entre essas praticas de cultivo (a ausência de um critério claro para essa distinção ficou evidente durante a realização do leventamento bibliográfico).

Duas análises foram adotadas na comparação mundial. Na primeira delas, as estratégias de subsistência foram caracterizadas através de estatísticas descritivas (média, 
desvio padrão, máximo e mínimo) e comparadas entre si através do teste não paramétrico de Kruskal-Wallis (ANOVA) (Beiguelman, 2002; Callegari-Jacques, 2003). Uma vez realizado este teste, compararam-se os dados de San Pedro de Atacama com as médias e o desvio padrão das populações mundiais. Os dados de San Pedro foram comparados sem a realização de testes de significância, já que, nesse primeiro momento, não foi possível comparar estatisticamente a incidência de uma população com médias de incidência de várias populações; observou-se apenas a posição de San Pedro no intervalo de um desvio padrão ao redor das médias das diferentes subsistências. Essa comparação apresenta a vantegem de mostrar distribuições ao redor da média, destacando o grau de sobreposição das diferentes estratégias de subsistência. Esta análise permite observar se as estratégias de subsistência podem ser consideradas categorias discretas para cada marcador osteológico.

A segunda análise consistiu na realização de uma comparação direta entre os dados dos subadultos de San Pedro de Atacama com as amostras mundiais. Foram aplicados testes qui-quadrado e Exato de Fisher comparando a freqüência absoluta de afetados de cada estratégia de subsistência com San Pedro de Atacama. Foi adotado nível de significância de 5\%. Esse procedimento estatístico apresenta um viés, uma vez que a frequência absoluta da estratégia de subsistência junta diferentes populações com tamanhos amostrais distintos. Caso uma das populações tenha um tamanho amostral muito alto ela irá enviesar o resultado em sua direção. Por outro lado, esse procedimento estatístico é o único capaz de comparar diretamente os dados de San Pedro com os do restante do mundo. É importante destacar, portanto, que essa estatística não substitui a comparação realizada pelo teste ANOVA, ambas são complementares e devem ser interpretados em conjunto.

A comparação com as amostras mundiais foi realizada utilizando-se o indivíduo como unidade de análise. No caso dos marcadores dentais (hipoplasia, cárie, abcesso), além da análise por indivíduo, foi realizada também uma análise com base no dente ou no alvéolo como unidade analítica. Estes três marcadores foram analisados separadamente para dentição decídua e permanente, com exceção de abcessos que teve os alvéolos de ambas as dentições unidos. No caso das infecções não específicas, foi realizada também a análise baseada apenas na tíbia, já que este é o osso mais susceptível a essas infecções (Larsen, 1997). Por fim, no caso do marcador hiperostose porótica, foi realizada a analise 
tanto de cribra orbitalia apenas, quanto para cribra e lesões na calota somadas (hiperostose porótica propriamente dita).

\section{2 - Resultados}

\subsection{1 - Hipoplasias lineares do esmalte dentário}

A incidência de hipoplasias nos esqueletos subadultos de San Pedro de Atacama não foi calculada por faixa etária; foi realizada apenas na comparação mundial (ver Material e Métodos).

O levantamento bibliográfico foi feito para hipoplasias lineares na dentição permanente, já que a grande maioria dos estudos incide sobre esse tipo de dentição. O resultado do levantamento está apresentado nas Tabelas 47 e 48. As unidades analíticas selecionadas para comparação foram: indivíduo, dente, incisivo central superior ou canino superior.

Os esqueletos subadultos de San Pedro de Atacama com dentição permanente apresentam 100\% dos indivíduos afetados por hipoplasia. Tal índice é o maior em comparação com as médias das diferentes estratégias de subsistência. No entanto, é importante ressaltar que a variabilidade dentro de cada tipo de subsistência é muito grande. Agricultura, por exemplo, apresenta valor máximo de 100\% e valor mínimo de 0\%; pesca caça-coleta apresenta valor máximo de 100\% e valor mínimo de 33,33\% (Tabela 49 e Figura 30). O teste não paramétrico de Kruskal-Wallis apresentou resultados significativos entre as médias das diferentes subsistências; o pós-teste de Dunn, em contrapartida, só acusou diferença significativa para a comparação entre as médias de “caça-coleta” e “urbano” (Tabela 50).

A incidência de dentes afetados só foi comparada com agricultores, uma vez que somente eles apresentaram dados para essa categoria. Os subadultos de San Pedro de Atacama apresentam uma incidência de 73,23\% de dentes afetados, que é superior ao valor máximo dos agricultores em geral (68,8\%). A porcentagem de San Pedro de Atacama é maior que a média dos agricultores em dois desvios padrões, caracterizando a diferença

como bastante expressiva (Tabela 49 e Figura 31). 
Tabela 47 - Levantamento bibliográfico dos estudos que apresentam dados para hipolasias.

\begin{tabular}{|c|c|c|c|}
\hline Série esqueletal & Subsistência* & Datação (BP)/ Período & Referências \\
\hline Damdama & $\mathrm{CC}$ & $7000-5000$ & Lucaks e Pal (1993) \\
\hline Dupont & $\mathrm{CC}$ & $4485-4100$ & Lanphear (1990) \\
\hline Furna do Estrago, Pernambuco & $\mathrm{CC}$ & $2000-1000$ & Mendonça de Souza (1995) \\
\hline Gangetic Plains, sul da Ásia & $\mathrm{CC}$ & Mesolítico & Lucaks e Pal (1993) \\
\hline India & $\mathrm{CC}$ & Mesolítico & Lucaks e Pal (1993) \\
\hline lugoslávia & $\mathrm{CC}$ & Mesolítico & Lucaks e Pal (1993) \\
\hline Mahadaha & $\mathrm{CC}$ & & Lucaks e Pal (1993) \\
\hline Norte da África e Europa & $\mathrm{CC}$ & Mesolítico & Lucaks e Pal (1993) \\
\hline Pré-agricultores pré-contato, Georgia, EUA & $\mathrm{CC}$ & $3050-800$ & Larsen et al. (2002) \\
\hline Todd`s Mound & $\mathrm{CC}$ & $1735-1550$ & Lanphear (1990) \\
\hline Sambaqui da Cabeçuda & PCC & & Mendonça de Souza (1995) \\
\hline Sambaqui da IIha de Espinheiros II & PCC & $2730+/-80$ & Wesolowski (2000) \\
\hline Sambaqui do Morro do Ouro 2 & PCC & & Wesolowski (2000) \\
\hline Sambaqui do Morro do Ouro I & PCC & $4030+/-40$ & Wesolowski (2000) \\
\hline Sambaqui do Rio Comprido 2 & PCC & $4815-4120$ & Wesolowski (2000) \\
\hline Sítio Itararé Enseada I CR & $\mathrm{PCC} / \mathrm{Ho} ?$ & & Wesolowski (2000) \\
\hline Sítio Itararé Itacoara & $\mathrm{PCC} / \mathrm{Ho} ?$ & & Wesolowski (2000) \\
\hline Dickson Mounds, EUA & Mista & Late Woodland & Lanphear (1990) \\
\hline Valley of Oaxaca & Mista & Formativo & Lanphear (1990) \\
\hline Academy Gym, Ilhas Marianas & $\mathrm{Ag} ?$ & $429+$ & Pietrusewski et al. (1997) \\
\hline Apurguam, Ilhas Marianas & $\mathrm{Ag} ?$ & $950-429$ & Pietrusewski et al. (1997) \\
\hline Apurguam, Ilhas Marianas & Ho? & 904-337 & Douglas et al. (1997) \\
\hline Basketmaker III, Anasazi, EUA & $\mathrm{Ag}$ & $1450-1250$ & Malville (1997) \\
\hline Budakalasz, Hungria & $\mathrm{Ag} ?$ & $4050-3850$ & Molnar e Molnar (1985) \\
\hline Cemitério de Kulubnarti, Núbia & $\mathrm{Ag}$ & 1400-1200 (Período Medieval antigo) & Van Gerven et al. (1990) \\
\hline Dickson Mounds, EUA & $\mathrm{Ag}$ & Mississipian Late Woodland aculturado & Lanphear (1990) \\
\hline First African Baptism Church & $\mathrm{Ag}$ & 127-109 & Lanphear (1990) \\
\hline Fujita Drainfiels, Ilhas Marianas & $\mathrm{Ag} ?$ & $1360-1050$ & Pietrusewski et al. (1997) \\
\hline Grupo de contato antigo, Georgia, EUA & $\mathrm{Ag}$ & $400-270$ & Larsen et al. (2002) \\
\hline Grupo de contato posterior, Georgia, EUA & $\mathrm{Ag}$ & $264-248$ & Larsen et al. (2002) \\
\hline Grupo pré-contato Anazasi, Georgia, EUA & $\mathrm{Ag}$ & $800-400$ & Larsen et al. (2002) \\
\hline
\end{tabular}




\begin{tabular}{|c|c|c|c|}
\hline Harappa, Paquistão & $\mathrm{Ag}$ & Idade do Bronze & Lucaks (1992) \\
\hline Jiangzhai, China & $\mathrm{Ag}$ & 7000-6000 (Yangshao) & Pechenkina et al. (2002) \\
\hline Kangjia, China & $\mathrm{Ag}$ & 4500-4000 (Longshan) & Pechenkina et al. (2002) \\
\hline Kiskore-Gat, Hungria & $\mathrm{Ag} ?$ & 4950-4550 (Neolítico tardio) & Molnar e Molnar (1985) \\
\hline Leo Palace, Ilhas Marianas & $\mathrm{Ag} ?$ & $950-550$ & Pietrusewski et al. (1997) \\
\hline Maia antigo, México & $\mathrm{Ag}$ & $2550-1350$ & Wright (1997) \\
\hline Mehrgarh, sul da Ásia & $\mathrm{Ag} ?$ & Neolítico & Lucaks e Pal (1993) \\
\hline Mehrgarh, sul da Ásia & $\mathrm{Ag} ?$ & Chalcolítico & Lucaks e Pal (1993) \\
\hline Mendes, Egito & $\mathrm{Ag} ?$ & $4950-4130 / \sim 2282-1455$ & Lovell e Whyte (1999) \\
\hline Nova Raca, Croácia & $\mathrm{Ag}$ & 650-150 (Medieval posterior) & Slaus (2000) \\
\hline Núbia & $\mathrm{Ag}$ & -450? (Período Feudal posterior) & Van Gerven et al. (1990) \\
\hline Oleais, Ilhas Marianas & $\mathrm{Ag} ?$ & $429+$ & Pietrusewski et al. (1997) \\
\hline Período Clássico posterior, Maia, México & $\mathrm{Ag}$ & $1350-1120$ & Wright (1997) \\
\hline Período Clássico Terminal Maia, México & $\mathrm{Ag}$ & $1120-1000$ & Wright (1997) \\
\hline Pitvaros, Hungria & $\mathrm{Ag} ?$ & $2850-2750$ & Molnar e Molnar (1985) \\
\hline Poundbury Camp, Inglaterra & $\mathrm{Ag}$ & １500 (Idade do Bronze a Era Saxã) & Stuart-Macadam (1985) \\
\hline Pueblo I, Anazasi, EUA & $\mathrm{Ag}$ & $1250-1050$ & Malville (1997) \\
\hline Pueblo II, Anazasi, EUA & $\mathrm{Ag}$ & $1050-850$ & Malville (1997) \\
\hline Pueblo III, Anazasi, EUA & $\mathrm{Ag}$ & $850-650$ & Malville (1997) \\
\hline Raund Furnells, Inglaterra & $\mathrm{Ag}$ & $1050-750$ & Lewis (2002) \\
\hline Right-of-Way, Ilhas Marianas & $\mathrm{Ag} ?$ & $470-285$ & Pietrusewski et al. (1997) \\
\hline Rota, Ilhas Marianas TOTAL & $\mathrm{Ag}$ & & Pietrusewski et al. (1997) \\
\hline Shijia, China & $\mathrm{Ag}$ & 6000-5000 (Yangshao) & Pechenkina et al. (2002) \\
\hline Tape & $\mathrm{Ag} ?$ & 2300-2150 (Idade do Bronze) & Molnar e Molnar (1985) \\
\hline Tiniam, Ilhas Marianas TOTAL & $\mathrm{Ag}$ & & Pietrusewski et al. (1997) \\
\hline Tiszafured-Majoros, Hungria & $\mathrm{Ag} ?$ & $3650-2450$ & Molnar e Molnar (1985) \\
\hline Tiszapolgar-basatanya, Hungria & $\mathrm{Ag} ?$ & $4350-4250$ & Molnar e Molnar (1985) \\
\hline Turpin e State Line & $\mathrm{Ag}$ & 775 & Lanphear (1990) \\
\hline Valley of Oaxaca & $\mathrm{Ag}$ & Clássico & Lanphear (1990) \\
\hline Valley of Oaxaca & $\mathrm{Ag}$ & Pós-Clássico & Lanphear (1990) \\
\hline Veszto-Magori Halom, Hungria & $\mathrm{Ag} ?$ & 4850-4450 (Neolítico tardio) & Molnar e Molnar (1985) \\
\hline Catoctin & Esc & & Kelley e Angel (1987) \\
\hline Cemitério escravo, Barbados & Esc & 300- 150 & Corruccini et al. (1982) \\
\hline Newton Plantation & Esc & $290-130$ & Lanphear (1990) \\
\hline
\end{tabular}




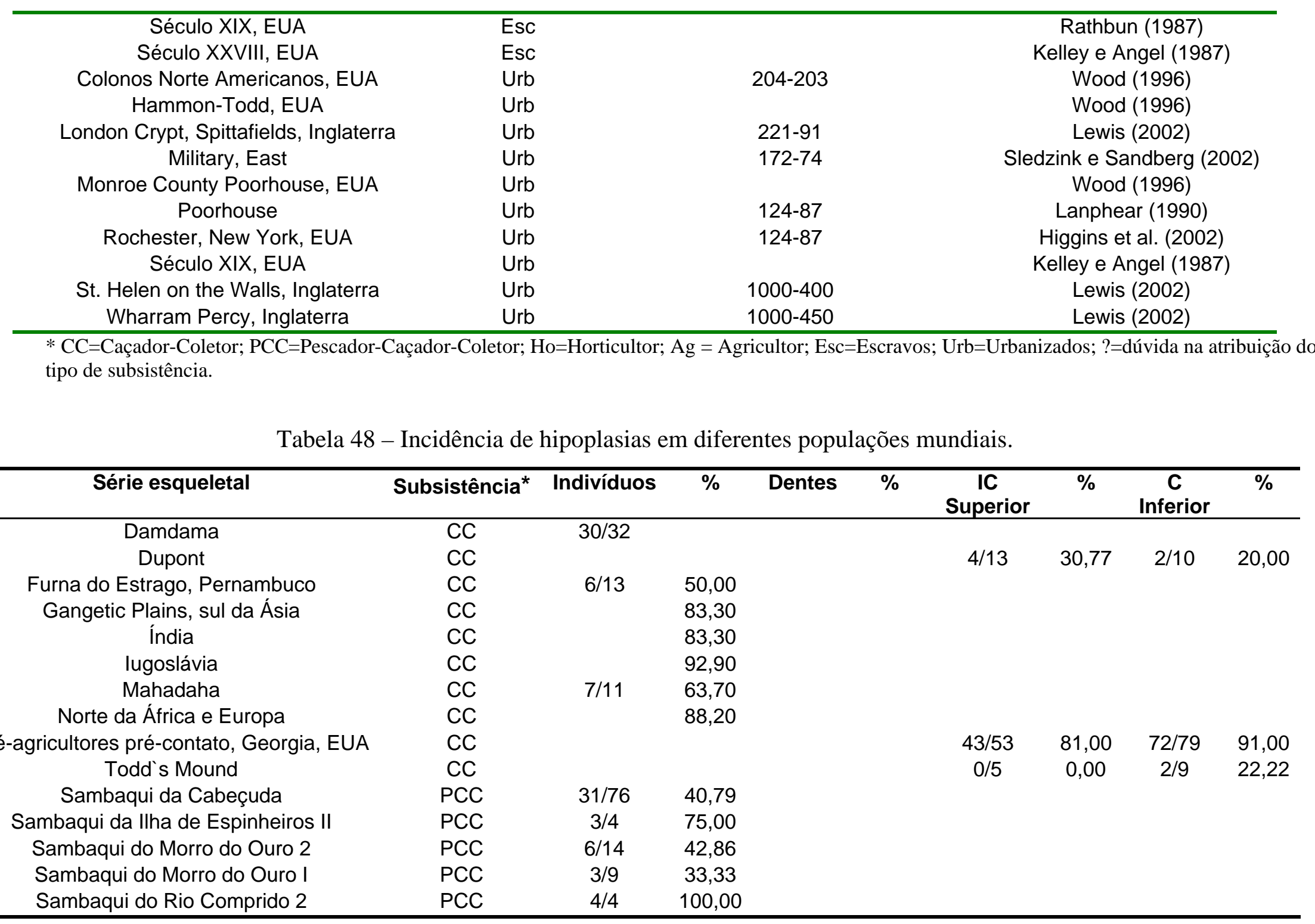




\begin{tabular}{|c|c|c|c|c|c|c|c|c|c|}
\hline Sítio Itararé Enseada I CR & $\mathrm{PCC} / \mathrm{Ho} ?$ & $4 / 7$ & 57,14 & & & & & & \\
\hline Sítio Itararé Itacoara & $\mathrm{PCC} / \mathrm{Ho} ?$ & $6 / 14$ & 42,86 & & & & & & \\
\hline Dickson Mounds, EUA & Mista & $9 / 20$ & 45,00 & & & & & & \\
\hline Valley of Oaxaca & Mista & & & & & $33 / 89$ & 37,08 & $83 / 134$ & 61,94 \\
\hline Academy Gym, Ilhas de Marianas & $\mathrm{Ag} ?$ & & & $0 / 6$ & 0,00 & & & & \\
\hline Apurguam, Ilhas Marianas & $\mathrm{Ag} ?$ & & & $110 / 342$ & 32,20 & & & & \\
\hline Apurguam, Ilhas Marianas & Ho? & & & $130 / 577$ & 22,50 & & & & \\
\hline Basketmaker III, Anasazi, EUA & $\mathrm{Ag}$ & $6 / 8$ & 75,00 & & & & & & \\
\hline Budakalasz, Hungria & Ag? & $23 / 44$ & 52,00 & $58 / 836$ & 6,94 & & & & \\
\hline Cemitério de Kulubnarti, Núbia & $\mathrm{Ag}$ & $31 / 31$ & 100,00 & & & & & & \\
\hline Dickson Mounds, EUA & $\mathrm{Ag}$ & $27 / 45$ & 60,00 & & & & & & \\
\hline First African Baptism Church & $\mathrm{Ag}$ & $60 / 73$ & 82,20 & & & & & & \\
\hline Fujita Drainfiels, Ilhas Marianas & Ag? & & & $23 / 78$ & 29,50 & & & & \\
\hline Grupo de contato antigo, Georgia, EUA & $\mathrm{Ag}$ & & & & & $55 / 77$ & 71,00 & $120 / 138$ & 87,00 \\
\hline Grupo de contato posterior, Georgia, EUA & $\mathrm{Ag}$ & & & & & $18 / 50$ & 36,00 & $26 / 51$ & 51,00 \\
\hline Grupo pré-contato Anazasi, Georgia, EUA & $\mathrm{Ag}$ & & & & & $43 / 65$ & 66,00 & $75 / 97$ & 77,00 \\
\hline Harappa, Paquistão & $\mathrm{Ag}$ & $26 / 36$ & 72,20 & & & & & & \\
\hline Jiangzhai, China & $\mathrm{Ag}$ & & & $38 / 115$ & 33,04 & & & & \\
\hline Kangjia, China & $\mathrm{Ag}$ & & & $25 / 44$ & 56,81 & & & & \\
\hline Kiskore-Gat, Hungria & Ag? & $0 / 6$ & 0,00 & $0 / 152$ & 0,00 & & & & \\
\hline Leo Palace, Ilhas Marianas & Ag? & & & $28 / 65$ & 43,10 & & & & \\
\hline Maia antigo, México & $\mathrm{Ag}$ & & & & & $5 / 17$ & 29,41 & $8 / 15$ & 53,33 \\
\hline Mehrgarh, sul da Ásia & Ag? & 0,613 & 61,30 & & & & & & \\
\hline Mehrgarh, sul da Ásia & Ag? & 0,627 & 62,70 & & & & & & \\
\hline Mendes, Egito & Ag? & & & $51 / 359$ & 19,69 & & & & \\
\hline Nova Raca, Croácia & $\mathrm{Ag}$ & $27 / 74$ & 36,50 & & & $37 / 118$ & 31,30 & $48 / 136$ & 35,30 \\
\hline Núbia & $\mathrm{Ag}$ & $56 / 56$ & 100,00 & & & & & & \\
\hline Oleais, Ilhas Marianas & Ag? & & & $22 / 32$ & 68,80 & & & & \\
\hline Período Clássico posterior, Maia, México & $\mathrm{Ag}$ & & & & & $12 / 31$ & 38,71 & $21 / 40$ & 52,50 \\
\hline Período Clássico Terminal Maia, México & $\mathrm{Ag}$ & & & & & $16 / 40$ & 40,00 & $30 / 45$ & 66,67 \\
\hline Pitvaros, Hungria & Ag? & $5 / 10$ & 50,00 & $10 / 234$ & 4,27 & & & & \\
\hline Poundbury Camp, Inglaterra & $\mathrm{Ag}$ & $176 / 457$ & 38,50 & & & & & & \\
\hline Pueblo I, Anazasi, EUA & $\mathrm{Ag}$ & $34 / 36$ & 94,00 & & & & & & \\
\hline Pueblo II, Anazasi, EUA & $\mathrm{Ag}$ & $32 / 34$ & 94,00 & & & & & & \\
\hline
\end{tabular}




\begin{tabular}{|c|c|c|c|c|c|c|c|c|c|}
\hline Pueblo III, Anazasi, EUA & $\mathrm{Ag}$ & $40 / 63$ & 86,00 & & & & & & \\
\hline Raund Furnells, Inglaterra & $\mathrm{Ag}$ & $23 / 72$ & 32,00 & & & & & & \\
\hline Right-of-Way, Ilhas Marianas & $\mathrm{Ag}$ ? & & & 0/13 & 0,00 & & & & \\
\hline Rota, Ilhas Mariana TOTAL & $\mathrm{Ag}$ & & & $12 / 30$ & 40,00 & & & & \\
\hline Shijia, China & $\mathrm{Ag}$ & & & $4 / 43$ & 9,30 & & & & \\
\hline Tape & $\mathrm{Ag} ?$ & $9 / 30$ & 30,00 & $42 / 832$ & 4,98 & & & & \\
\hline Tiniam, Ilhas Mariana TOTAL & $\mathrm{Ag}$ & & & $0 / 4$ & 0,00 & & & & \\
\hline Tiszafured-Majoros, Hungria & $\mathrm{Ag} ?$ & $7 / 34$ & 20,50 & $19 / 889$ & 2,14 & & & & \\
\hline Tiszapolgar-basatanya, Hungria & $\mathrm{Ag} ?$ & $5 / 28$ & 17,90 & $18 / 594$ & 3,03 & & & & \\
\hline Turpin e State Line & $\mathrm{Ag}$ & & & & & $46 / 87$ & 52,87 & $76 / 107$ & 71,03 \\
\hline Valley of Oaxaca & $\mathrm{Ag}$ & & & & & $18 / 44$ & 40,91 & $44 / 67$ & 66,67 \\
\hline Valley of Oaxaca & $\mathrm{Ag}$ & & & & & $27 / 57$ & 47,37 & $57 / 84$ & 67,86 \\
\hline Veszto-Magori Halom, Hungria & $\mathrm{Ag}$ ? & $0 / 10$ & 0,00 & $0 / 240$ & 0,00 & & & & \\
\hline Catoctin & Esc & $7 / 16$ & 46,00 & & & & & & \\
\hline Cemitério escravo, Barbados & Esc & $66 / 68$ & 97,60 & & & & & & \\
\hline Newton Plantation & Esc & $56 / 103$ & 54,37 & & & & & & \\
\hline Século XIX & Esc & $24 / 31$ & 77,00 & & & & & & \\
\hline Século XXVIII & Esc & $14 / 25$ & 56,00 & & & & & & \\
\hline Colonos Norte Americanos, EUA & Urb & & & & & $14 / 31$ & 45,00 & 23/38 & 61,00 \\
\hline Hammon-Todd, EUA & Urb & & & & & & 84,90 & & 86,70 \\
\hline London Crypt, Spittafields, Inglaterra & Urb & $22 / 91$ & 24,00 & & & & & & \\
\hline Military, East & Urb & & & & & & & $18 / 69$ & 26,10 \\
\hline Monroe County Poorhouse, EUA & Urb & & & & & & 63,60 & & 45,90 \\
\hline Poorhouse & Urb & & & & & $161 / 225$ & 71,56 & $74 / 107$ & 69,16 \\
\hline Rochester, New York, EUA & Urb & $129 / 3196$ & 4,03 & & & & & & \\
\hline Século XIX, EUA & Urb & $9 / 34$ & 26,00 & & & & & & \\
\hline St. Helen on the Walls, Inglaterra & Urb & $31 / 92$ & 34,00 & & & & & & \\
\hline Wharram Percy, Inglaterra & Urb & $36 / 120$ & & & & & & & \\
\hline
\end{tabular}

* CC=Caçador-Coletor; PCC=Pescador-Caçador-Coletor; Ho=Horticultor; Ag = Agricultor; Esc=Escravos; Urb=Urbanizados; ?=dúvida na atribuição do tipo de subsistência. 
Tabela 49 - Estatísticas descritivas de hipoplasias em diferentes estratégias de subsistência, comparadas com os dados dos subadultos

\begin{tabular}{|c|c|c|c|c|c|c|c|c|}
\hline & & Indivíduos & & Dentes & & IC Superior & & C Inferior \\
\hline \multirow[t]{5}{*}{ Caça-Coleta } & Média & 76,90 & Média & - & Média & 37,26 & Média & 44,41 \\
\hline & Desv Pad & 16,51 & Desv Pad & - & Desv Pad & 40,89 & Desv Pad & 40,37 \\
\hline & $\operatorname{Max}$ & 92,90 & $\operatorname{Max}$ & - & Max & 81,00 & Max & 91,00 \\
\hline & Mínimo & 50,00 & Mínimo & - & Mínimo & 0,00 & Mínimo & 20,00 \\
\hline & $\mathrm{N}$ & 6 & $\mathrm{~N}$ & - & $\mathrm{N}$ & 3 & $\mathrm{~N}$ & 3 \\
\hline \multirow[t]{5}{*}{ Pesca-Caça-Coleta } & Média & 56,00 & Média & - & Média & - & Média & - \\
\hline & Desv Pad & 23,77 & Desv Pad & - & Desv Pad & - & Desv Pad & - \\
\hline & Max & 100,00 & $\operatorname{Max}$ & - & Max & - & Max & - \\
\hline & Mínimo & 33,33 & Mínimo & - & Mínimo & - & Mínimo & - \\
\hline & $\mathrm{N}$ & 7 & $N$ & - & $\mathrm{N}$ & - & $\mathrm{N}$ & - \\
\hline \multirow[t]{5}{*}{ Mista } & Média & 45,00 & Média & - & Média & 37,08 & Média & 61,94 \\
\hline & Desv Pad & - & Desv Pad & - & Desv Pad & - & Desv Pad & - \\
\hline & Max & 45,00 & Max & - & Max & 37,08 & $\operatorname{Max}$ & 61,94 \\
\hline & Mínimo & 45,00 & Mínimo & - & Mínimo & 37,08 & Mínimo & 61,94 \\
\hline & $N$ & 1 & $\mathrm{~N}$ & - & $N$ & 1 & $N$ & 1 \\
\hline \multirow{5}{*}{ Agricultura ou Horticultura } & Média & 55,47 & Média & 18,82 & Média & 45,36 & Média & 62,84 \\
\hline & Desv Pad & 31,64 & Desv Pad & 21,05 & Desv Pad & 14,05 & Desv Pad & 14,91 \\
\hline & Max & 100,00 & Max & 68,80 & Max & 71,00 & Max & 87,00 \\
\hline & Mínimo & 0,00 & Mínimo & 0,00 & Mínimo & 29,41 & Mínimo & 35,30 \\
\hline & N & 21 & N & 20 & $\mathrm{~N}$ & 10 & $\mathrm{~N}$ & 10 \\
\hline \multirow[t]{5}{*}{ Escravos } & Média & 66,19 & Média & - & Média & - & Média & - \\
\hline & Desv Pad & 20,94 & Desv Pad & - & Desv Pad & - & Desv Pad & - \\
\hline & Max & 97,60 & Max & - & Max & - & Max & - \\
\hline & Mínimo & 46,00 & Mínimo & - & Mínimo & - & Mínimo & - \\
\hline & $\mathrm{N}$ & 5 & $\mathrm{~N}$ & - & $\mathrm{N}$ & - & $\mathrm{N}$ & - \\
\hline \multirow[t]{5}{*}{ Urbano } & Média & 22,01 & Média & - & Média & 66,27 & Média & 57,77 \\
\hline & Desv Pad & 12,74 & Desv Pad & - & Desv Pad & 16,68 & Desv Pad & 23,03 \\
\hline & Max & 34,00 & $\operatorname{Max}$ & - & $\operatorname{Max}$ & 84,90 & Max & 86,70 \\
\hline & Mínimo & 4,03 & Mínimo & - & Mínimo & 45,00 & Mínimo & 26,10 \\
\hline & $\mathrm{N}$ & 4 & $\mathrm{~N}$ & - & $\mathrm{N}$ & 4 & $N$ & 5 \\
\hline San Pedro - Subadultos (perm.) & & 15/15 (100,00\%) & & $93 / 127(73,23 \%)$ & & $12 / 17(\mathbf{7 0}, \mathbf{5 9 \%})$ & & $22 / 25(\mathbf{8 8}, \mathbf{0 0} \%)$ \\
\hline
\end{tabular}


Tabela 50 - Valores de P do teste Kruskal-Wallis e dos pós-testes de Dunn, comparando as médias de indivíduos afetados por hipoplasias das diferentes estratégias de subsistência.

\begin{tabular}{cc}
$\star$ & $\mathrm{P}^{\star \star}$ \\
\hline Kruskal-Wallis & $\mathbf{0 , 0 4 9 0}$ \\
PCC vs. CC & $>0.05$ \\
PCC vs. Ag ou Ho & $>0.05$ \\
PCC vs. Esc & $>0.05$ \\
PCC vs. Urb & $>0.05$ \\
CC vs. Ag ou Ho & $>0.05$ \\
CC vs. Esc & $>0.05$ \\
CC vs. Urb & $<0.05$ \\
Ag ou Ho vs. Esc & $>0.05$ \\
Ag ou Ho vs. Urb & $>0.05$ \\
Esc vs. Urb & $>0.05$ \\
\hline
\end{tabular}

* CC=Caçador-Coletor; PCC=Pescador Caçador-Coletor; Ho=Horticultor; Ag = Agricultor; Esc=Escravos; Urb=Urbanizados. ** valores em negrito são significantes. 


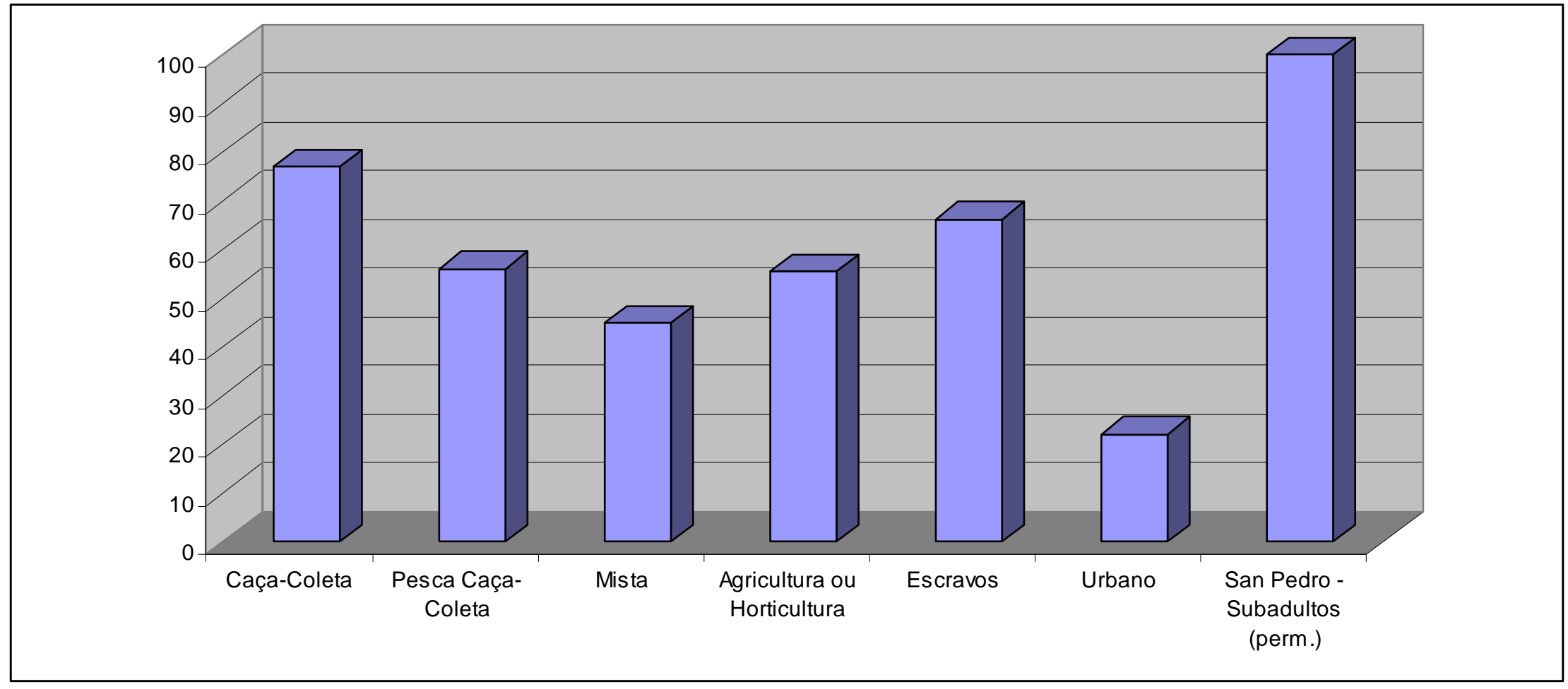

Figura 30 - Comparação entre a porcentagem de indivíduos afetados por hipoplasias em San Pedro de Atacama (dentição permanente) e as médias da diferentes estratégias de subsistência. 


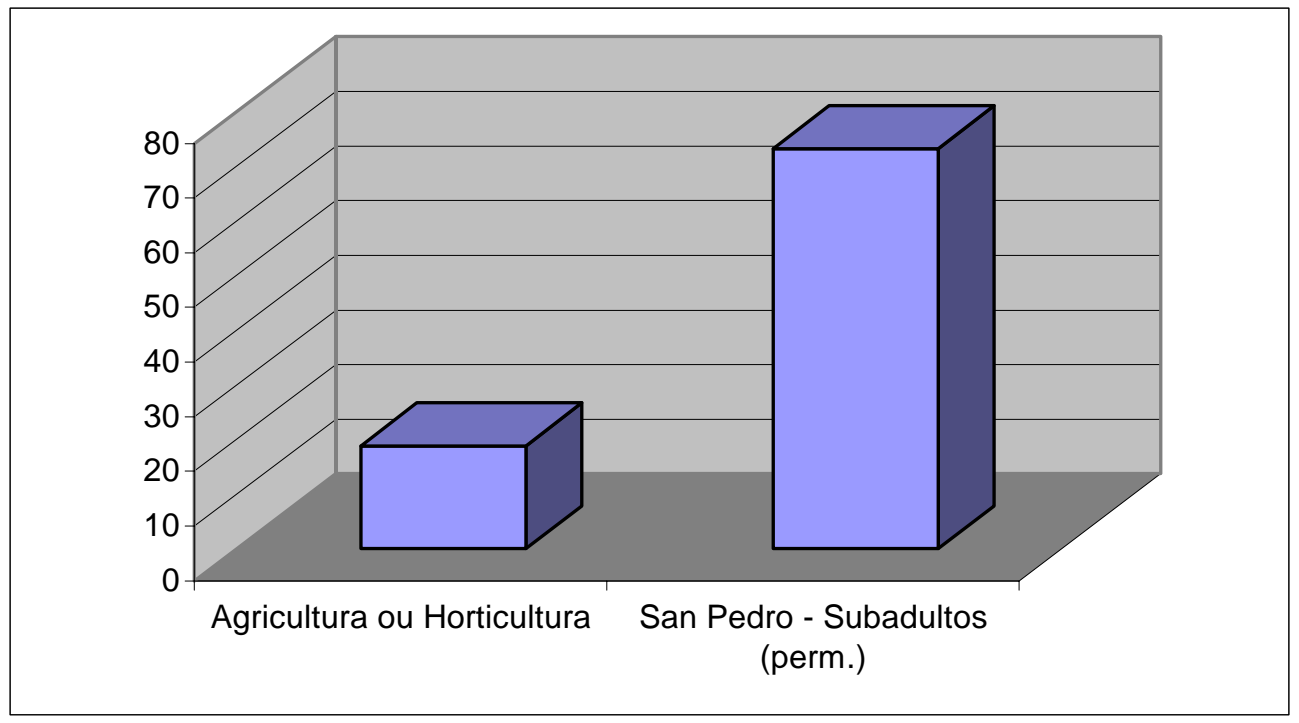

Figura 31 - Comparação entre a porcentagem de dentes afetados por hipoplasias em San Pedro de Atacama (dentição permanente) e a média das populações agricultoras.

Os valores para os incisivos centrais superiores e caninos inferiores afetados em San Pedro de Atacama são maiores que as médias das diferentes estratégias de subsistência. Já a porcentagem de incisivos centrais superiores afetados em San Pedro de Atacama é mais próxima da média das populações urbanizadas, enquanto a porcentagem para os caninos inferiores em San Pedro é mais próxima das populações com subsistência mista (Tabela 49 e Figuras 32 e 33). O teste estatístico Kruskal-Wallis e o pós-teste de Dunn não apresentaram resultados significativos ao comparar as médias das diferentes subsistências (Tabelas 51 e 52).

A comparação direta das frequências absolutas de hipoplasias entre os subadultos de San Pedro de Atacama e as amostras mundiais foi feita utilizando-se o teste qui-quadrado e o Exato de Fisher. "Caça-coleta" foi a única categoria que não apresentou diferença significativa com San Pedro de Atacama utilizando indivíduo (Tabela 53) e canino inferior como unidade (Tabela 54). Já utilizando dente como unidade houve diferença significativa entre San Pedro e agricultores (Tabela 55); enquanto para incisivo central superior somente a população com subsistência mista apresentou diferença significativa com os subadultos atacamenhos (Tabela 56). 
Tabela 51 - Valores de P do teste Kruskal-Wallis e dos pós-testes de Dunn, comparando as médias dos incisivos centrais superiores afetados por hipoplasias nas diferentes estratégias de subsistência.

\begin{tabular}{cc}
\hline$*$ & $\mathrm{P}$ \\
\hline Kruskal-Wallis & 0,1459 \\
CC vs. Ag ou Ho & $>0.05$ \\
CC vs. Urb & $>0.05$ \\
Ag ou Ho vs. Urb & $>0.05$ \\
\hline Ho Horticultor; Ag $=$ Agricultor; Urb=Urbanizados.
\end{tabular}

Tabela 52 - Valores de P do teste Kruskal-Wallis e dos pós-testes de Dunn, comparando as médias dos caninos inferiores afetados por hipoplasias nas diferentes estratégias de subsistência.

\begin{tabular}{cc}
\hline$*$ & $\mathrm{P}$ \\
\hline Kruskal-Wallis & 0,6191 \\
CC vs. Ag ou Ho & $>0.05$ \\
CC vs. Urb & $>0.05$ \\
Ag ou Ho vs. Urb & $>0.05$ \\
\hline
\end{tabular}

* CC=Caçador-Coletor; Ho=Horticultor; Ag = Agricultor; Urb=Urbanizados .

Tabela 53 - Comparação entre as freqüências absolutas (hipoplasias) das diferentes estratégias de subsistência com San Pedro de Atacama, através dos testes Qui-quadrado e Exato de Fisher (indivíduo como unidade de análise).

\begin{tabular}{cccccc}
\hline Estratégias de subsistência & Populações & $\begin{array}{c}\text { Frequência } \\
\text { absoluta }\end{array}$ & Porcentagem Qui-Quadrado $(\mathbf{P})^{*}$ Fisher $(\mathbf{P})^{*}$ \\
\hline Caça-Coleta & 3 & $43 / 56$ & 76,79 & 0,0913 & 0,0566 \\
Pesca-Caça-Coleta & 7 & $57 / 128$ & 44,53 & $\mathbf{0 , 0 0 0 1}$ & $<\mathbf{0 , 0 0 0 1}$ \\
Mista & 1 & $9 / 20$ & 45,00 & $\mathbf{0 , 0 0 1 9}$ & $\mathbf{0 , 0 0 0 5}$ \\
Agricultura ou Horticultura & 20 & $623 / 1267$ & 49,17 & $\mathbf{0 , 0 0 0 3}$ & $<\mathbf{0 , 0 0 0 1}$ \\
Escravo & 5 & $167 / 243$ & 68,72 & $\mathbf{0 , 0 2 2 2}$ & $\mathbf{0 , 0 0 6 8}$ \\
Urbano & 4 & $191 / 3413$ & 5,60 & $<\mathbf{0 , 0 0 0 1}$ & - \\
San Pedro de Atacama & & $15 / 15$ & 100,00 & & \\
\hline
\end{tabular}

* os valores em negrito foram considerados significativos 
Tabela 54 - Comparação entre as freqüências absolutas (hipoplasias) das diferentes estratégias de subsistência com San Pedro de Atacama, através dos testes Qui-quadrado e Exato de Fisher (canino inferior como unidade de análise).

\begin{tabular}{cccccc}
\hline Estratégia de subsistência & Populações Frequência absoluta & Porcentagem & Qui-Quadrado (P) & Fisher (P) \\
\hline Caça-Coleta & 3 & $76 / 98$ & 77,55 & 0,3786 & 0,4029 \\
Mista & 1 & $83 / 134$ & 61,94 & $\mathbf{0 , 0 2 1 7}$ & $\mathbf{0 , 0 1 1 3}$ \\
Agricultura ou Horticultura & 11 & $528 / 818$ & 64,55 & $\mathbf{0 , 0 2 6 9}$ & $\mathbf{0 , 0 1 7 3}$ \\
Urbano & 2 & $92 / 176$ & 52,27 & $\mathbf{0 , 0 0 1 6}$ & $\mathbf{0 , 0 0 0 9}$ \\
San Pedro de Atacama & & $22 / 25$ & 88,00 & & \\
\hline
\end{tabular}

* os valores em negrito foram considerados significativos

Tabela 55 - Comparação entre as freqüências absolutas (hipoplasia) de agricultor ou horticultor com San Pedro de Atacama, através do teste Qui-quadrado (dente como unidades de análise).

\begin{tabular}{lcccc}
\hline Estratégia de subsistência & Populações & Frequência absoluta & Porcentagem & Qui-Quadrado (P)* \\
\hline Agricultura ou Horticultura & 20 & $590 / 5485$ & 10,76 & $<\mathbf{0 , 0 0 0 1}$ \\
San Pedro de Atacama & $93 / 127$ & 73,23 & \\
\hline * o valor em negrito foi considerado significativo &
\end{tabular}

Tabela 56 - Comparação entre as freqüências absolutas (hipoplasia) das diferentes estratégias de subsistência com San Pedro de Atacama, através do teste Qui-quadrado e Exato de Fisher (incisivo central superior como unidades de análise).

\begin{tabular}{cccccc}
\hline Estratégia de subsistência & Populações & Frequência absoluta & Porcentagem & Qui-Quadrado $(\mathbf{P})^{*}$ Fisher $(\mathbf{P})^{*}$ \\
\hline Caça-Coleta & 3 & $47 / 71$ & 66,20 & 0,9532 & 1,0000 \\
Agricultura ou Horticultura & 11 & $291 / 617$ & 47,16 & 0,0826 & 0,0966 \\
Mista & 1 & $33 / 89$ & 37,08 & $\mathbf{0 , 0 2 1 8}$ & $\mathbf{0 , 0 1 5 1}$ \\
Urbano & 1 & $161 / 225$ & 71,56 & 0,9321 & 1,0000 \\
San Pedro de Atacama & & $12 / 17$ & 70,59 & & \\
\hline
\end{tabular}

* os valores em negrito foram considerados significativos 


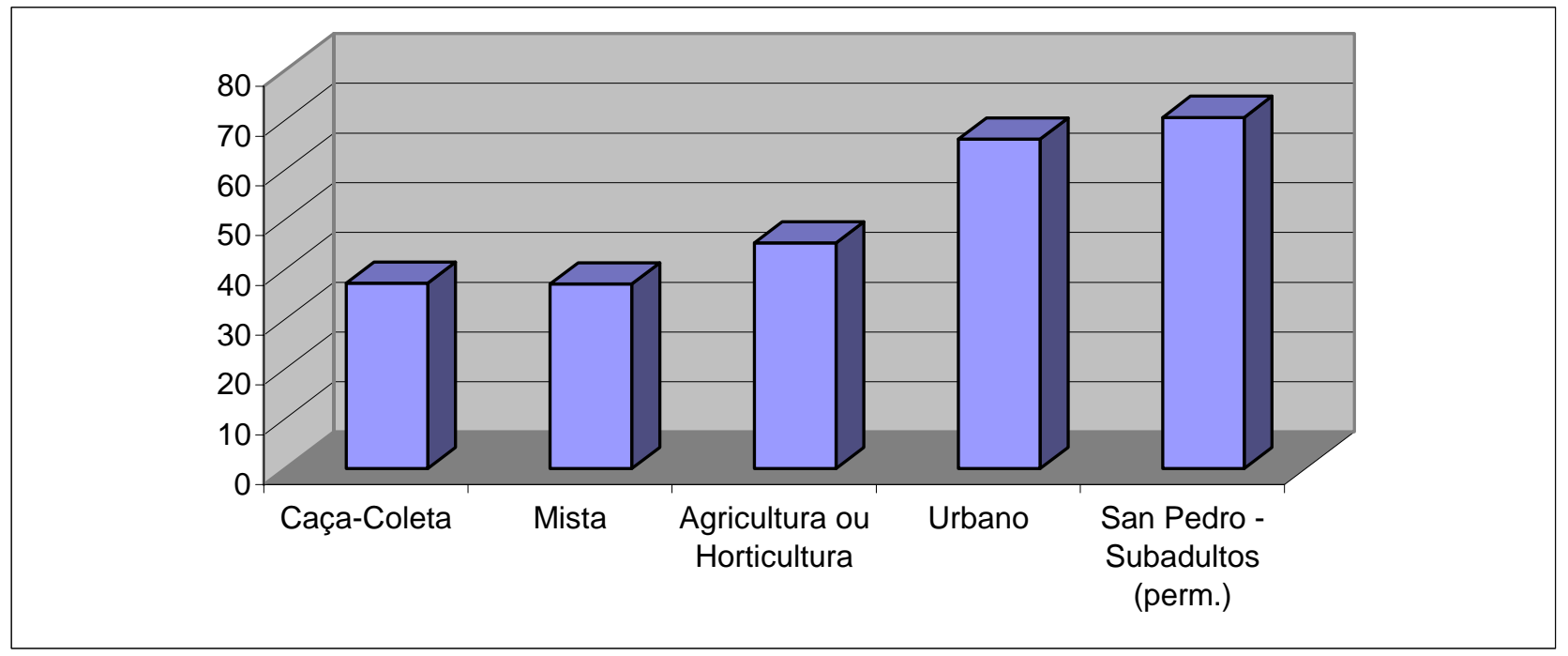

Figura 32 - Comparação entre a porcentagem de incisivos centrais superiores afetados por hipoplasias em San Pedro de Atacama (dentição permanente) e as médias das diferentes estratégias de subsistência.

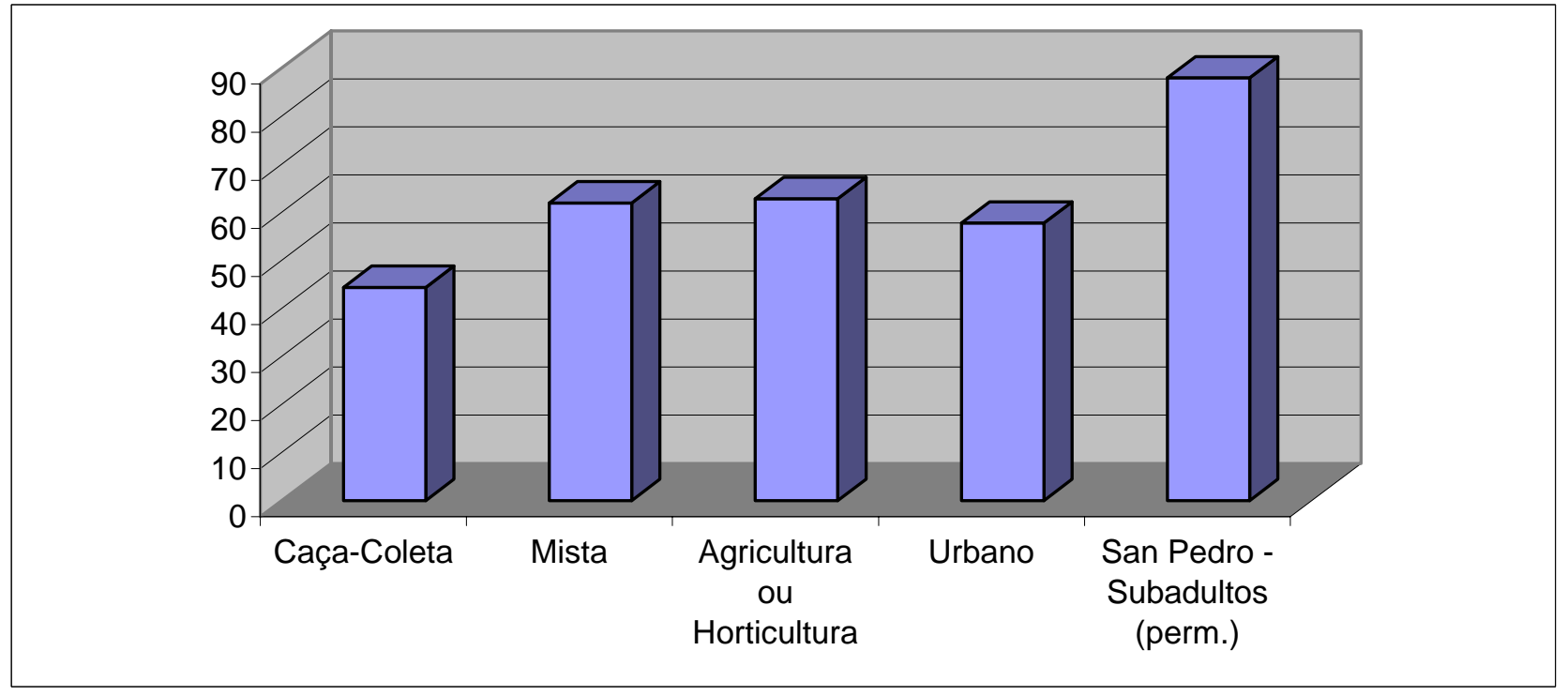

Figura 33 - Comparação entre a porcentagem de caninos inferiores afetados por hipoplasias em San Pedro de Atacama (dentição permanente) e as médias das diferentes estratégias de subsistência. 
Os poucos dados sobre esqueletos subadultos com dentição permanente estão nas Tabelas 57 e 58. Os resultados mostram que em comparação com os subadultos do restante do mundo a incidência de hipoplasias em San Pedro de Atacama é a mais alta, concordando com o padrão obtido na comparação com esqueletos adultos.

\subsection{2 - Abcessos}

Os abcessos nos alvéolos dos esqueletos subadultos de San Pedro de Atacama tiveram sua primeira aparição aos três anos de idade, na dentição decídua. A incidência de abcessos nos alvéolos da dentição decídua chega a 60\% entre quatro e dez anos (Tabela 59 e Figura 34). Na dentição permanente os indivíduos afetados estão na faixa etária de dez a vinte anos, chegando ao máximo de 22,22\% entre dez a quinze anos (Tabela 60 e Figura 35).

A comparação com as amostras mundiais foi feita somando-se os dados de San Pedro para dentição permanente e decídua, já que a literatura não diferencia essas duas categorias. Foi realizado para os subadultos de San Pedro de Atacama um teste Quiquadrado comparando as frequências de afetados por abcessos entre a dentição decídua e a permanente, apresentando resultados não significativos tanto para indivíduos afetados como para alvéolos afetados (Tabela 61). Esses resultados legitimam a união das duas dentições em uma amostra única.

O levantamento bibliográfico para abscessos está nas Tabelas 62 e 63. Os dados da literatura foram divididos em duas categorias: os que utilizam a unidade “indivíduos” e os que utilizam a unidade “alvéolos”.

A comparação dos subadultos de San Pedro de Atacama, usando indivíduo como unidade, com as médias das diferentes estratégias de subsistência mostrou que os primeiros apresentaram incidência de abscessos (18,75\%), muito próxima à média dos agricultores em geral (18,02\%) (Tabela 64 e Figura 36). O teste ANOVA paramétrico (dados adequamse à uma distribuição normal) apresentou resultado significativo ao comparar as médias das diferentes estratégias de subsistência; porém, os pós-testes de Tukey, ao comparar os pares de médias, resultaram em apenas um teste significativo: entre agricultores e caçadorescoletores (Tabela 65). 
Tabela 57 - Levantamento bibliográfico dos estudos que apresentam dados para hipolasias na dentição permanente em subadultos.

\begin{tabular}{ccccc}
\hline Série esqueletal & Subsistência Datação (BP)/ Período & Referências & Faixa Etária \\
\hline Santa Elena, Equador & $\mathrm{CC}$ & $8250-6600$ & Ubelaker \& Newson (2002) & \\
Anasazi, EUA & $\mathrm{Ag}$ & $1450-650$ & Malville (1997) & \\
Copan rural, Maia & $\mathrm{Ag}$ & $-1150-950$ & Storey et al. (2002) & até 14 anos \\
Copan urbano, Maia & $\mathrm{Ag}$ & $-1150-950$ & Storey et al. (2002) & até 14 anos \\
Historic Indian, Equador & $\mathrm{Ag}$ ? & $450-300$ & Ubelaker \& Newson (2002) & \\
Jaina, Maia & $\mathrm{Ag}$ & $1350-950$ & Storey et al. (2002) & até 14 anos \\
North Coast, Equador & $\mathrm{Ag}$ & $2550-1550$ & Ubelaker \& Newson (2002) & \\
Nova Raca, Croácia & $\mathrm{Ag}$ & $650-150$ & Slaus (2000) & até 16 anos \\
Poundbury Camp, Inglaterra & $\mathrm{Ag}$ & -1500 & Stuart-Macadam (1985) & \\
Prehistoric Highland, Equador & $\mathrm{Ag} ?$ & $2950-1500$ & Ubelaker \& Newson (2002) & \\
Raund Furnells, Inglaterra & $\mathrm{Ag}$ & $1050-750$ & Lewis (2002) & até 17 anos \\
Real Alto, Equador & $\mathrm{Ag}$ & $5350-3450$ & Ubelaker \& Newson (2002) & \\
South Coast, Equador & $\mathrm{Ag}$ & $2850-220$ & Ubelaker \& Newson (2002) & \\
Século XIX, EUA & Esc & $50-150$ & Rathbun (1987) & até 15 anos \\
European 2 & Urb & $280-92$ & Ubelaker \& Newson (2002) & \\
London Crypt, Spittafields, Inglaterra & Urb & $221-91$ & Lewis (2002) & até 17 anos \\
St. Helen on the Walls, Inglaterra & Urb & $1000-400$ & Lewis (2002) & até 17 anos \\
Wharram Percy, Inglaterra & Urb & $1000-450$ & Lewis (2002) & até 17 anos \\
\hline
\end{tabular}

* CC=Caçador-Coletor; Ag = Agricultor; Esc=Escravo; Urb=Urbano. 
Tabela 58 - Incidência de hipoplasias na dentição permanente em diferentes populações mundiais subadultas.

\begin{tabular}{|c|c|c|c|c|c|c|c|c|c|c|}
\hline Série esqueletal & Subsistência' & ndivíduos & $\%$ & Dentes & $\%$ & $\begin{array}{c}\text { IC } \\
\text { superior }\end{array}$ & $\%$ & $\begin{array}{c}\text { C } \\
\text { inferior }\end{array}$ & $\%$ & $\begin{array}{c}\text { Variações } \\
\text { metodológicas }\end{array}$ \\
\hline Santa Elena, Equador & $\mathrm{CC}$ & & & & & $0 / 4$ & 0,00 & $1 / 7$ & 14,29 & Todos os C e I \\
\hline Anasazi, EUA & $\mathrm{Ag}$ & $39 / 45$ & 86,67 & $202 / 315$ & 64,13 & & & & & \\
\hline Copan rural, Maia & $\mathrm{Ag}$ & & & & & & & $2 / 3$ & 66,67 & Todos os C \\
\hline Copan urbano, Maia & $\mathrm{Ag}$ & & & & & & & $36 / 42$ & 85,71 & Todos os C \\
\hline Historic Indian, Equador & $\mathrm{Ag} ?$ & & & & & $1 / 2$ & 50,00 & $0 / 2$ & 0,00 & Todos os C e I \\
\hline Jaina, Maia & $\mathrm{Ag}$ & & & & & & & $2 / 3$ & 66,67 & Todos os C \\
\hline North Coast, Equador & $\mathrm{Ag}$ & & & & & $1 / 2$ & 50,00 & $1 / 2$ & 50,00 & Todos os C e I \\
\hline Nova Raca, Croácia & $\mathrm{Ag}$ & & & & & $10 / 13$ & 76,92 & $9 / 14$ & 64,29 & \\
\hline Poundbury Camp, Inglaterra & $\mathrm{Ag}$ & $26 / 57$ & 45,61 & & & & & & & \\
\hline Prehistoric Highland, Equador & $\mathrm{Ag} ?$ & & & & & $0 / 12$ & 0,00 & $1 / 12$ & 8,33 & Todos os C e I \\
\hline Raund Furnells, Inglaterra & $\mathrm{Ag}$ & & & & & & & $23 / 72$ & 31,94 & \\
\hline Real Alto, Equador & $\mathrm{Ag}$ & & & & & $0 / 7$ & 0,00 & $1 / 6$ & 16,67 & Todos os C e I \\
\hline South Coast, Equador & $\mathrm{Ag}$ & & & & & $0 / 5$ & 0,00 & $1 / 6$ & 16,67 & Todos os C e I \\
\hline Século XIX, EUA & Esc & $1 / 4$ & 25,00 & & & & & & & \\
\hline European 2 & Urb & & & & & $0 / 1$ & 0,00 & $0 / 2$ & 0,00 & Todos os C e I \\
\hline London Crypt, Spittafields, Inglaterra & Urb & & & & & & & $22 / 91$ & 24,18 & \\
\hline St. Helen on the Walls, Inglaterra & Urb & & & & & & & $21 / 104$ & 20,19 & \\
\hline Wharram Percy, Inglaterra & Urb & & & & & & & $36 / 120$ & 30,00 & \\
\hline San Pedro - Subadultos (perm.) & $\mathrm{Ag}$ & $15 / 15$ & 100,00 & $93 / 127$ & 73,23 & $12 / 17$ & 70,59 & $22 / 25$ & 88,00 & \\
\hline
\end{tabular}

* CC=Caçador-Coletor; Ag = Agricultor; Esc=Escravo; Urb=Urbano. 
Tabela 59 - Freqüência absoluta e porcentagem de indivíduos afetados em San Pedro de Atacama por abcessos na dentição decídua.

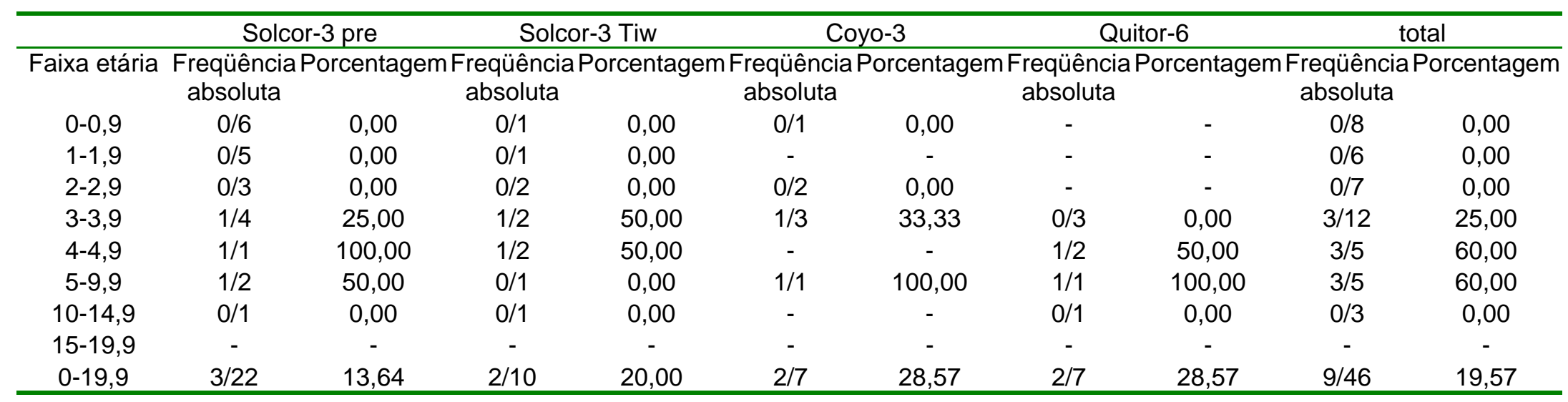

Tabela 60 - Freqüência absoluta e porcentagem de indivíduos afetados em San Pedro de Atacama por abcessos na dentição permanente.

\begin{tabular}{|c|c|c|c|c|c|c|c|c|c|c|}
\hline & \multicolumn{2}{|c|}{ Solcor-3 pre } & \multicolumn{2}{|c|}{ Solcor-3 Tiw } & \multicolumn{2}{|c|}{ Coyo-3 } & \multicolumn{2}{|r|}{ Quitor-6 } & \multicolumn{2}{|r|}{ total } \\
\hline Faixa etária & $\begin{array}{c}\text { Freqüência } \\
\text { absoluta }\end{array}$ & rcentag & $\begin{array}{r}\text { TFreqüênci } \\
\text { absoluta }\end{array}$ & orcentag & $\begin{array}{l}\text { nFreqüênci } \\
\text { absoluta }\end{array}$ & Sorcentage & $\begin{array}{l}\text { nFreqüênc } \\
\text { absoluta }\end{array}$ & cia Porcentas & $\begin{array}{l}\text { nFreqüênc } \\
\text { absoluta }\end{array}$ & la Porcentagem \\
\hline $0-0,9$ & - & - & - & - & - & - & - & - & - & - \\
\hline $1-1,9$ & - & - & - & - & - & - & - & - & - & - \\
\hline $2-2,9$ & - & - & - & - & - & - & - & - & - & - \\
\hline $3-3,9$ & - & - & - & - & - & - & - & - & - & - \\
\hline $4-4,9$ & - & - & - & - & - & - & - & - & - & - \\
\hline $10-14,9$ & $1 / 5$ & 20,00 & $0 / 1$ & 0,00 & $1 / 1$ & 100,00 & $0 / 2$ & 0,00 & $2 / 9$ & 22,22 \\
\hline $15-19,9$ & $0 / 3$ & 0,00 & $1 / 2$ & 50,00 & $0 / 1$ & 0,00 & - & - & $1 / 6$ & 16,67 \\
\hline $0-19,9$ & $1 / 10$ & 10,00 & $1 / 3$ & 33,33 & $1 / 2$ & 50,00 & $0 / 3$ & 0,00 & $3 / 18$ & 16,67 \\
\hline
\end{tabular}


Tabela 61 - Comparação entre a freqüência de abcessos da dentição decídua e da permanente na população subadulta de San Pedro de Atacama e o valor de P do teste Qui-quadrado. Foram realizadas as comparações usando indivíduo e alvéolo como unidade de análise.

\begin{tabular}{cccc}
\hline & Dentição perm. & Dentição dec. & Qui-quadrado (P) \\
\hline Indivíduo & $3 / 18$ & $9 / 46$ & 0,7894 \\
Alvéolo & $6 / 399$ & $21 / 737$ & 0,2235 \\
\hline
\end{tabular}

Tabela 62 - Levantamento bibliográfico dos estudos que apresentam dados para abcessos.

\begin{tabular}{|c|c|c|c|}
\hline Série esqueletal & Subsistência* & Datação (BP)/ Período & Referências \\
\hline Aleuts & $\mathrm{CC}$ & $3450-950$ & Keenleyside (1998) \\
\hline Central Oregon & $\mathrm{CC}$ & & Hall et al. (1986) \\
\hline Coast of Oregon & $\mathrm{CC}$ & & Hall et al. (1986) \\
\hline Damdama & $\mathrm{CC}$ & $7000-5000$ & Lucaks e Pal (1993) \\
\hline Equestrian nomads, EUA & $\mathrm{CC}$ & & Johansson e Owsley (2002) \\
\hline Eskimos & $\mathrm{CC}$ & $1450-1050 / 550-100$ & Keenleyside (1998) \\
\hline Espanha & $\mathrm{CC}$ & Mesolítico & Lucaks e Pal (1993) \\
\hline Europa composta & $\mathrm{CC}$ & Mesolítico & Lucaks e Pal (1993) \\
\hline Furna do Estrago, Pernambuco & $\mathrm{CC}$ & $2000-1000$ & Rodrigues (1997) \\
\hline Gangetic Plains, sul da Ásia & $\mathrm{CC}$ & Mesolítico & Lucaks e Pal (1993) \\
\hline India & $\mathrm{CC}$ & Mesolítico & Lucaks e Pal (1993) \\
\hline lugoslávia & $\mathrm{CC}$ & Mesolítico & Lucaks e Pal (1993) \\
\hline Klamath Basin, Oregon & $\mathrm{CC}$ & & Hall et al. (1986) \\
\hline Lower Columbia Valley, Oregon & $\mathrm{CC}$ & & Hall et al. (1986) \\
\hline Mahadaha & $\mathrm{CC}$ & Mesolítico & Lucaks e Pal (1993) \\
\hline Nubia sudanesa & $\mathrm{CC}$ & Mesolítico & Lucaks e Pal (1993) \\
\hline Santa Elena, Equador & $\mathrm{CC}$ & $8250-6600$ & Ubelaker e Newson (2002) \\
\hline Willamette Valley, Oregon & $\mathrm{CC}$ & & Hall et al. (1986) \\
\hline Sambaqui de Areias Pequenas & PCC & & Wesolowski (1999) \\
\hline Sambaqui de Armação do Sul, Florianópolis & PCC & $2670+/-90$ & Haubert et al. (2004) \\
\hline Sambaqui de Balsinha I, Santa Catarina & PCC & $3780+/-90-2350+/-90$ & Haubert et al. (2004) \\
\hline Sambaqui de Cabeçuda Sítio 1, Santa Catarina & PCC & $4120+/-220$ & Rodrigues (1997) \\
\hline Sambaqui de Cabeçuda Sítio 2 & PCC & $4120+/-220$ & Rodrigues (1997) \\
\hline Sambaqui de Conquista no 9 & PCC & & Wesolowski (2000) \\
\hline
\end{tabular}




\begin{tabular}{|c|c|c|c|}
\hline Sambaqui de Eneseada I PR & PCC & & Wesolowski (2000) \\
\hline Sambaqui de F. Marechal Luz PR & PCC & $4290+/-1230$ & Wesolowski (2000) \\
\hline Sambaqui de Ilha de Espinheiros II & PCC & $2730+/-80$ & Wesolowski (2000) \\
\hline Sambaqui de Jaboticabeiras II, Santa Catarina & PCC & & Storto et al. (1999) \\
\hline Sambaqui de Laranjeiras I, Santa Catarina & PCC & $3815+/-145$ & Haubert et al. (2004) \\
\hline Sambaqui do Morro do Ouro 2 & PCC & & Wesolowski (2000) \\
\hline Sambaqui do Morro do Ouro I & PCC & $4030+/-40$ & Wesolowski (2000) \\
\hline Sambaqui do Rio Comprido 1 & PCC & $4815-4120$ & Wesolowski (2000) \\
\hline Sambaqui do Rio Comprido 2 & PCC & $4815-4120$ & Wesolowski (2000) \\
\hline Sítio Itararé de Base Aérea, Florianópolis & $\mathrm{PCC} / \mathrm{Ho} ?$ & $800+/-70$ & Haubert et al (2004) \\
\hline Sítio Itararé de Cabeçudas, Santa Catarina & $\mathrm{PCC} / \mathrm{Ho} ?$ & & Haubert et al (2004) \\
\hline Sítio Itararé de Enseada I CR & $\mathrm{PCC} / \mathrm{Ho} ?$ & & Wesolowski (2000)) \\
\hline Sítio Itararé de F. Marechal Luz CR & $\mathrm{PCC} / \mathrm{Ho} ?$ & $620+/-100$ & Wesolowski (2000) \\
\hline Sítio Itararé de Itacoara & $\mathrm{PCC} / \mathrm{Ho} ?$ & & Wesolowski (2000) \\
\hline Sítio Itararé de Laranjeiras II, Santa Catarina & $\mathrm{PCC} / \mathrm{Ho}$ ? & & Haubert et al. (2004) \\
\hline Sítio Itararé de Praia de Tapera & $\mathrm{PCC} / \mathrm{Ho} ?$ & $1140+/-180-1030+/-180$ & Haubert et al. (2004) \\
\hline Abu Dhabi - Umm ar Nar, golfo da Arábia & Mista & $\sim 4450$ & Litleton e Frohlich (1993) \\
\hline Failaka, golfo da Arábia & Mista & $2250-2050$ & Litleton e Frohlich (1993) \\
\hline Pawnee, EUA & Mista & $200-130$ & Johansson e Owsley (2002) \\
\hline Apurguam, Ilhas Marianas & Ho? & $904-337$ & Douglas et al. (1997) \\
\hline Arikara, EUA & $\mathrm{Ag}$ & & Johansson e Owsley (2002) \\
\hline Bahrain, Golfo da Arábia & $\mathrm{Ag}$ & 4250-3750 (Idade do Bronze) & Litleton e Frohlich (1993) \\
\hline Bahrain, Golfo da Arábia & $\mathrm{Ag}$ & 2700-2450 (Idade do Ferro) & Litleton e Frohlich (1993) \\
\hline Bahrain, Golfo da Arábia & $\mathrm{Ag}$ & 700-450 (Islâmico) & Litleton e Frohlich (1993) \\
\hline Budakalasz, Hungria & $\mathrm{Ag} ?$ & $4050-3850$ & Molnar e Molnar (1985) \\
\hline Copan rural, Maia & $\mathrm{Ag}$ & $\sim 1150-950$ & Storey et al. (2002) \\
\hline Copan urban, Maia & $\mathrm{Ag}$ & $\sim 1150-950$ & Storey et al. (2002) \\
\hline Guam, Ilhas Marianas TOTAL & $\mathrm{Ag}$ & & Pietrosovieski et al. (1997) \\
\hline Harappa, Paquistão & $\mathrm{Ag}$ & Idade de Bronze & Lucaks (1992) \\
\hline Indígenas históricos, EUA & Ag? & $450-300$ & Ubelaker e Newson (2002) \\
\hline Jaina, Maia & $\mathrm{Ag}$ & $1350-950$ & Storey et al. (2002) \\
\hline Khulubnarti, norte do Sudão & $\mathrm{Ag}$ & $1400-450$ & Sheridan et al. (1991) \\
\hline Kiskore-Gat, Hungria & $\mathrm{Ag} ?$ & 4950-4550 (Neolítico tardio) & Molnar e Molnar (1985) \\
\hline Mehrgarh, sul da Ásia & $\mathrm{Ag} ?$ & Neolítico & Lucaks e Pal (1993) \\
\hline
\end{tabular}




\begin{tabular}{cccc}
\hline Mehrgarh, sul da Ásia & $\mathrm{Ag}$ ? & Chalcolítico & Lucaks e Pal (1993) \\
North Coast, EUA & $\mathrm{Ag}$ & $2550-1550$ & Ubelaker e Newson (2002) \\
Omaha, EUA & $\mathrm{Ho}$ & & Johansson e Owsley (2002) \\
Pitvaros, Hungria & $\mathrm{Ag} ?$ & $2850-2750$ & Molnar e Molnar (1985) \\
Prehistoric Highland, EUA & $\mathrm{Ag} ?$ & $2950-1500$ & Ubelaker e Newson (2002) \\
Real Alto, EUA & $\mathrm{Ag}$ & $5350-3450$ & Ubelaker e Newson (2002) \\
Rota, Ilhas Marianas TOTAL & $\mathrm{Ag}$ & & Pietrosovieski et al. (1997) \\
Saipan, Ilhas Marianas TOTAL & $\mathrm{Ag}$ & & Pietrosovieski et al. (1997) \\
Site 3 - Ras el Khaimah, Golfo da Arábia & $\mathrm{Ag} ?$ & $2050-1850$ & Litleton e Frohlich (1993) \\
Site 5 - Ras el Khaimah, Golfo da Arábia & $\mathrm{Ag} ?$ & $2050-1850$ & Litleton e Frohlich (1993) \\
South Coast, EUA & $\mathrm{Ag}$ & $2850-220$ & Ubelaker e Newson (2002) \\
Tape, Hungria & $\mathrm{Ag} ?$ & $2300-2150$ (Idade do Bronze) & Molnar e Molnar (1985) \\
Tiszafured-Majoros, Hungria & $\mathrm{Ag} ?$ & $3650-2450$ & Molnar e Molnar (1985) \\
Tiszapolgar-basatanya, Hungria & $\mathrm{Ag} ?$ & $4350-4250$ & Molnar e Molnar (1985) \\
Veszto-Magori Halom, Hungria & $\mathrm{Ag} ?$ & $4850-4450$ (Neolítico tardio) & Molnar e Molnar (1985) \\
Xcaret, Maia & $\mathrm{Ag}$ & Pós-Clássico & Storey et al. (2002) \\
Europeus 1 & Urb & $410-92$ & Ubelaker e Newson (2002) \\
Europeus 2 & Urb & $280-92$ & Ubelaker e Newson (2002) \\
Europeus 3 & Urb & $180-10$ & Ubelaker e Newson (2002) \\
Military, East & Urb & $172-74$ & Sledzink e Sandberg (2002) \\
\hline
\end{tabular}

* CC=Caçador-Coletor; PCC=Pescador-Caçador-Coletor; Ho=Horticultor; Ag = Agricultor; Urb=Urbanizados; ?=dúvida na atribuição do tipo de subsistência.

Tabela 63 - Incidência de abcessos em diferentes populações mundiais.

\begin{tabular}{cccccc}
\hline Série esqueletal & Subsistência* & Indivíduos & $\%$ & Alveolos & $\%$ \\
\hline Aleuts & CC & $38 / 57$ & 66,67 & $118 / 1566$ & 7,54 \\
Central Oregon & CC & $13 / 32$ & 41,00 & & \\
Coast of Oregon & CC & $19 / 39$ & 48,00 & & \\
Damdama & CC & $9 / 35$ & 25,70 & & \\
Equestrian nomads, EUA & CC & & & $63 / 2571$ & 2,50 \\
Eskimos & CC & $67 / 118$ & 56,78 & $210 / 3483$ & 6,03 \\
Espanha & CC & & 20,90 & & \\
Europa composta & CC & & 24,30 & & \\
\hline
\end{tabular}




\begin{tabular}{|c|c|c|c|c|c|}
\hline Furna do Estrago, Pernambuco & $\mathrm{CC}$ & & & $54 / 682$ & 7,90 \\
\hline Gangetic Plains, sul da Ásia & $\mathrm{CC}$ & & 21,80 & & \\
\hline Índia & $\mathrm{CC}$ & & 21,80 & & \\
\hline lugoslávia & $\mathrm{CC}$ & & 28,60 & & \\
\hline Klamath Basin, Oregon & $\mathrm{CC}$ & $27 / 43$ & 63,00 & & \\
\hline Lower Columbia Valley, Oregon & $\mathrm{CC}$ & $19 / 32$ & 59,00 & & \\
\hline Mahadaha & $\mathrm{CC}$ & $3 / 15$ & 20,00 & & \\
\hline Nubia sudanesa & $\mathrm{CC}$ & & 27,60 & & \\
\hline Santa Elena & $\mathrm{CC}$ & & & $13 / 353$ & 3,70 \\
\hline Willamette Valley, Oregon & $\mathrm{CC}$ & $20 / 46$ & 43,00 & & \\
\hline Sambaqui de Areias Pequenas & PCC & & & $4 / 89$ & 4,49 \\
\hline Sambaqui de Armação do Sul, Florianópolis & PCC & & & & 0,00 \\
\hline Sambaqui de Balsinha I, Santa Catarina & PCC & & & $3 / 358$ & 0,84 \\
\hline Sambaqui de Cabeçuda Sítio 1, Santa Catarina & PCC & & & $25 / 1064$ & 2,30 \\
\hline Sambaqui de Cabeçuda Sítio 2 & PCC & & & $13 / 608$ & 2,10 \\
\hline Sambaqui de Conquista no 9 & PCC & & & 0/39 & 0,00 \\
\hline Sambaqui de Eneseada I PR & PCC & & & 0/79 & 0,00 \\
\hline Sambaqui de F. Marechal Luz PR & PCC & & & $24 / 148$ & 16,22 \\
\hline Sambaqui de Ilha de Espinheiros II & PCC & & & $11 / 166$ & 6,63 \\
\hline Sambaqui de Jaboticabeiras II, Santa Catarina & PCC & & & & 0,04 \\
\hline Sambaqui de Laranjeiras I, Santa Catarina & PCC & $8 / 29$ & 27,59 & $11 / 471$ & 2,34 \\
\hline Sambaqui do Morro do Ouro 2 & PCC & & & $24 / 346$ & 6,94 \\
\hline Sambaqui do Morro do Ouro I & PCC & & & $37 / 285$ & 12,98 \\
\hline Sambaqui do Rio Comprido 1 & PCC & & & $0 / 76$ & 0,00 \\
\hline Sambaqui do Rio Comprido 2 & PCC & & & $1 / 93$ & 1,08 \\
\hline Sítio Itararé de Base Aérea, Florianópolis & $\mathrm{PCC} / \mathrm{Ho} ?$ & $12 / 61$ & 19,67 & $18 / 840$ & 2,14 \\
\hline Sítio Itararé de Cabeçudas, Santa Catarina & $\mathrm{PCC} / \mathrm{Ho} ?$ & $6 / 31$ & 19,35 & 9/495 & 1,82 \\
\hline Sítio Itararé de Enseada I CR & $\mathrm{PCC} / \mathrm{Ho} ?$ & & & $34 / 569$ & 5,98 \\
\hline Sítio Itararé de F. Marechal Luz CR & $\mathrm{PCC} / \mathrm{Ho} ?$ & & & $9 / 81$ & 11,11 \\
\hline Sítio Itararé de Itacoara & $\mathrm{PCC} / \mathrm{Ho} ?$ & & & $15 / 337$ & 4,45 \\
\hline Sítio Itararé de Laranjeiras II, Santa Catarina & $\mathrm{PCC} / \mathrm{Ho} ?$ & $19 / 46$ & 41,30 & $32 / 1172$ & 2,73 \\
\hline Sítio Itararé de Praia de Tapera & $\mathrm{PCC} / \mathrm{Ho} ?$ & $27 / 72$ & 37,50 & $61 / 1892$ & 3,22 \\
\hline Abu Dhabi - Umm ar Nar, golfo da Arábia & Mista & & & $46 / 779$ & 5,90 \\
\hline Failaka, golfo da Arábia & Mista & $1 / 8$ & 12,50 & $8 / 207$ & 3,90 \\
\hline
\end{tabular}




\begin{tabular}{|c|c|c|c|c|c|}
\hline Pawnee, EUA & Mista & & & $54 / 1290$ & 4,20 \\
\hline Apurguam, Ilhas Marianas & Ho? & & & $59 / 1153$ & 5,10 \\
\hline Arikara, EUA & $\mathrm{Ag}$ & & & $152 / 1802$ & 8,40 \\
\hline Bahrain, Golfo da Arábia & $\mathrm{Ag}$ & $10 / 69$ & 14,60 & $19 / 928$ & 2,16 \\
\hline Bahrain, Golfo da Arábia & $\mathrm{Ag}$ & $24 / 98$ & 24,10 & $43 / 834$ & 5,20 \\
\hline Bahrain, Golfo da Arábia & $\mathrm{Ag}$ & $8 / 25$ & 31,80 & $33 / 626$ & 5,30 \\
\hline Budakalasz, Hungria & $\mathrm{Ag} ?$ & & & $5 / 836$ & 0,50 \\
\hline Copan rural, Maia & $\mathrm{Ag}$ & & & & 11,00 \\
\hline Copan urban, Maia & $\mathrm{Ag}$ & & & & 2,00 \\
\hline Guam, Ilhas Marianas TOTAL & $\mathrm{Ag}$ & & & $81 / 1745$ & 4,60 \\
\hline Harappa, Paquistão & $\mathrm{Ag}$ & $7 / 38$ & 18,40 & $23 / 752$ & 3,06 \\
\hline Indígenas históricos, EUA & $\mathrm{Ag} ?$ & & & $5 / 180$ & 2,80 \\
\hline Jaina, Maia & $\mathrm{Ag}$ & & & & 2,00 \\
\hline Khulubnarti, norte do Sudão & $\mathrm{Ag}$ & & & $122 / 172$ & 70,90 \\
\hline Kiskore-Gat, Hungria & Ag? & & & $5 / 152$ & 3,20 \\
\hline Mehrgarh, sul da Ásia & $\mathrm{Ag} ?$ & & 6,30 & & \\
\hline Mehrgarh, sul da Ásia & $\mathrm{Ag} ?$ & & 12,90 & & \\
\hline North Coast, EUA & $\mathrm{Ag}$ & & & $30 / 617$ & 4,90 \\
\hline Omaha, EUA & $\mathrm{Ho}$ & & & $37 / 1021$ & 3,60 \\
\hline Pitvaros, Hungria & $\mathrm{Ag} ?$ & & & $6 / 234$ & 2,50 \\
\hline Prehistoric Highland, EUA & $\mathrm{Ag} ?$ & & & 14/1095 & 1,30 \\
\hline Real Alto, EUA & $\mathrm{Ag}$ & & & $50 / 550$ & 9,10 \\
\hline Rota, Ilhas Marianas TOTAL & $\mathrm{Ag}$ & & & $9 / 190$ & 4,70 \\
\hline Saipan, Ilhas Marianas TOTAL & $\mathrm{Ag}$ & & & $32 / 445$ & 7,20 \\
\hline Site 3 - Ras el Khaimah, Golfo da Arábia & $\mathrm{Ag} ?$ & & & $1 / 34$ & 3,00 \\
\hline Site 5 - Ras el Khaimah, Golfo da Arábia & $\mathrm{Ag} ?$ & & & $3 / 112$ & 2,30 \\
\hline South Coast, EUA & $\mathrm{Ag}$ & & & $101 / 766$ & 13,20 \\
\hline Tape, Hungria & $\mathrm{Ag} ?$ & & & $13 / 832$ & 1,60 \\
\hline Tiszafured-Majoros, Hungria & $\mathrm{Ag} ?$ & & & $0 / 889$ & 0,00 \\
\hline Tiszapolgar-basatanya, Hungria & $\mathrm{Ag} ?$ & & & $3 / 594$ & 0,50 \\
\hline Veszto-Magori Halom, Hungria & $\mathrm{Ag} ?$ & & & $3 / 240$ & 1,30 \\
\hline Xcaret, Maia & $\mathrm{Ag}$ & & & & 3,00 \\
\hline Europeus 1 & Urb & & & $4 / 335$ & 1,20 \\
\hline Europeus 2 & Urb & & & $32 / 425$ & 7,50 \\
\hline
\end{tabular}




\begin{tabular}{cccc}
\hline Europeus 3 & Urb & $8 / 492$ & 1,60 \\
Military, East & Urb & $79 / 1971$ & 4,01 \\
\hline
\end{tabular}

* CC=Caçador-Coletor; PCC=Pescador-Caçador-Coletor; Ho=Horticultor; Ag = Agricultor; Urb=Urbanizados; ?=dúvida na atribuição do tipo de subsistência.

Tabela 64 - Estatísticas descritivas de abcessos em diferentes subsistências, comparadas com os dados dos subadultos de San Pedro de Atacama.

\begin{tabular}{|c|c|c|c|c|}
\hline & & Indivíduos & & Alvéolos \\
\hline \multirow[t]{5}{*}{ Caça-Coleta } & Média & 37,88 & Média & 5,53 \\
\hline & Desv Pad & 17,01 & Desv Pad & 2,37 \\
\hline & $\operatorname{Max}$ & 66,67 & $\operatorname{Max}$ & 7,90 \\
\hline & Mínimo & 20,00 & Mínimo & 2,50 \\
\hline & $\mathrm{N}$ & 15 & $\mathrm{~N}$ & 5 \\
\hline \multirow[t]{5}{*}{ Pesca Caça-Coleta } & Média & 29,08 & Média & 3,97 \\
\hline & Desv Pad & 10,07 & Desv Pad & 4,46 \\
\hline & Max & 41,30 & Max & 16,22 \\
\hline & Mínimo & 19,35 & Mínimo & 0,00 \\
\hline & $N$ & 5 & $\mathrm{~N}$ & 22 \\
\hline \multirow[t]{5}{*}{ Mista } & Média & 12,50 & Média & 4,67 \\
\hline & Desv Pad & - & Desv Pad & 1,08 \\
\hline & $\operatorname{Max}$ & 12,50 & Max & 5,90 \\
\hline & Mínimo & 12,50 & Mínimo & 3,90 \\
\hline & $\mathrm{N}$ & 1 & $\mathrm{~N}$ & 3 \\
\hline \multirow[t]{5}{*}{ Agricultura ou horticultura } & Média & 18,02 & Média & 6,36 \\
\hline & Desv Pad & 8,97 & Desv Pad & 12,81 \\
\hline & $\operatorname{Max}$ & 31,80 & Max & 70,90 \\
\hline & Mínimo & 6,30 & Mínimo & 0,00 \\
\hline & $N$ & 6 & $\mathrm{~N}$ & 29 \\
\hline \multirow[t]{5}{*}{ Urbano } & Média & - & Média & 3,58 \\
\hline & Desv Pad & - & Desv Pad & 2,89 \\
\hline & $\operatorname{Max}$ & - & Max & 7,50 \\
\hline & Mínimo & - & Mínimo & 1,20 \\
\hline & $\mathrm{N}$ & - & $\mathrm{N}$ & 4 \\
\hline San Pedro - Subadultos & & 12/64 (18,75\%) & & $27 / 1136(2,38 \%)$ \\
\hline
\end{tabular}


Tabela 65 - Valores de P do teste ANOVA paramétrico e dos pós-testes de Tukey, comparando as médias de indivíduos afetados por abcessos nas diferentes estratégias de subsistência.

\begin{tabular}{cc}
\hline$* *$ & $P^{*}$ \\
\hline ANOVA & $\mathbf{0 . 0 3 0 1}$ \\
PCC vs CC & $>0,05$ \\
PCC vs Ag ou Ho & $>0,05$ \\
Ag ou Ho vs CC & $<0,05$ \\
\hline * valor em negrito é significante
\end{tabular}

** CC=Caçador-Coletor; PCC=Pescador Caçador-Coletor; Ho=Horticultor; Ag = Agricultor.

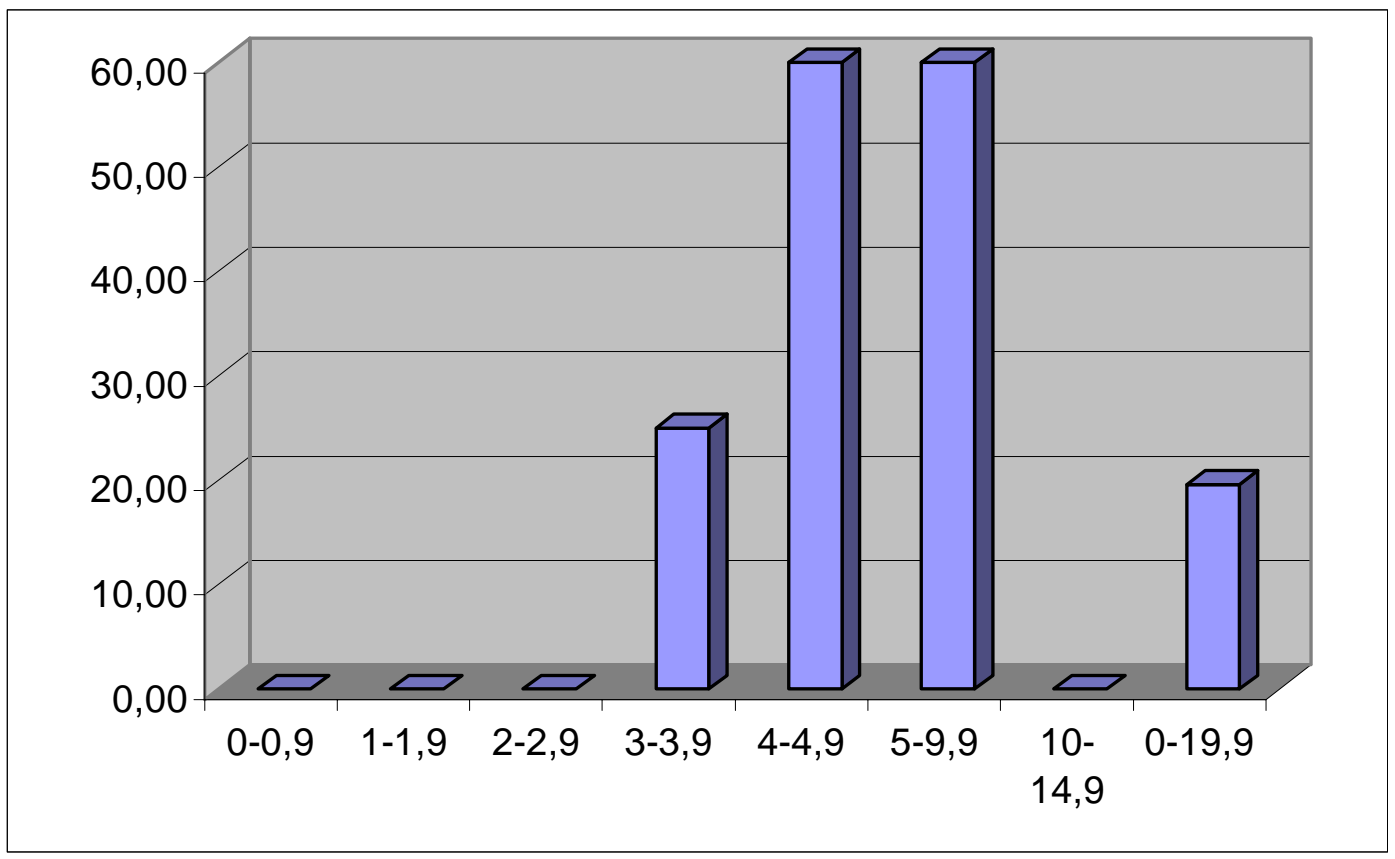

Figura 34 - Distribuição por faixa etária da porcentagem de indivíduos afetados por abcessos com dentição decídua em San Pedro de Atacama. 


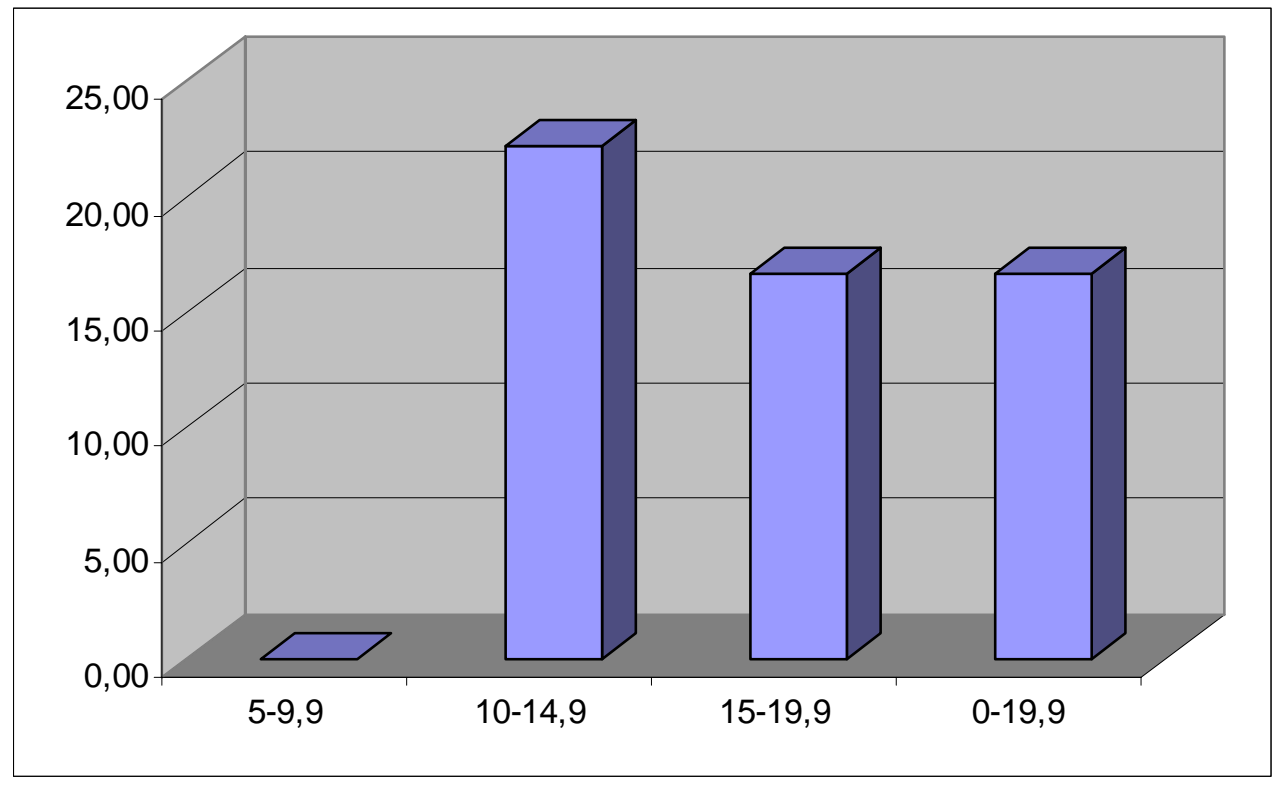

Figura 35 - Distribuição por faixa etária da porcentagem de indivíduos afetados por abcessos com dentição permanente em San Pedro de Atacama.

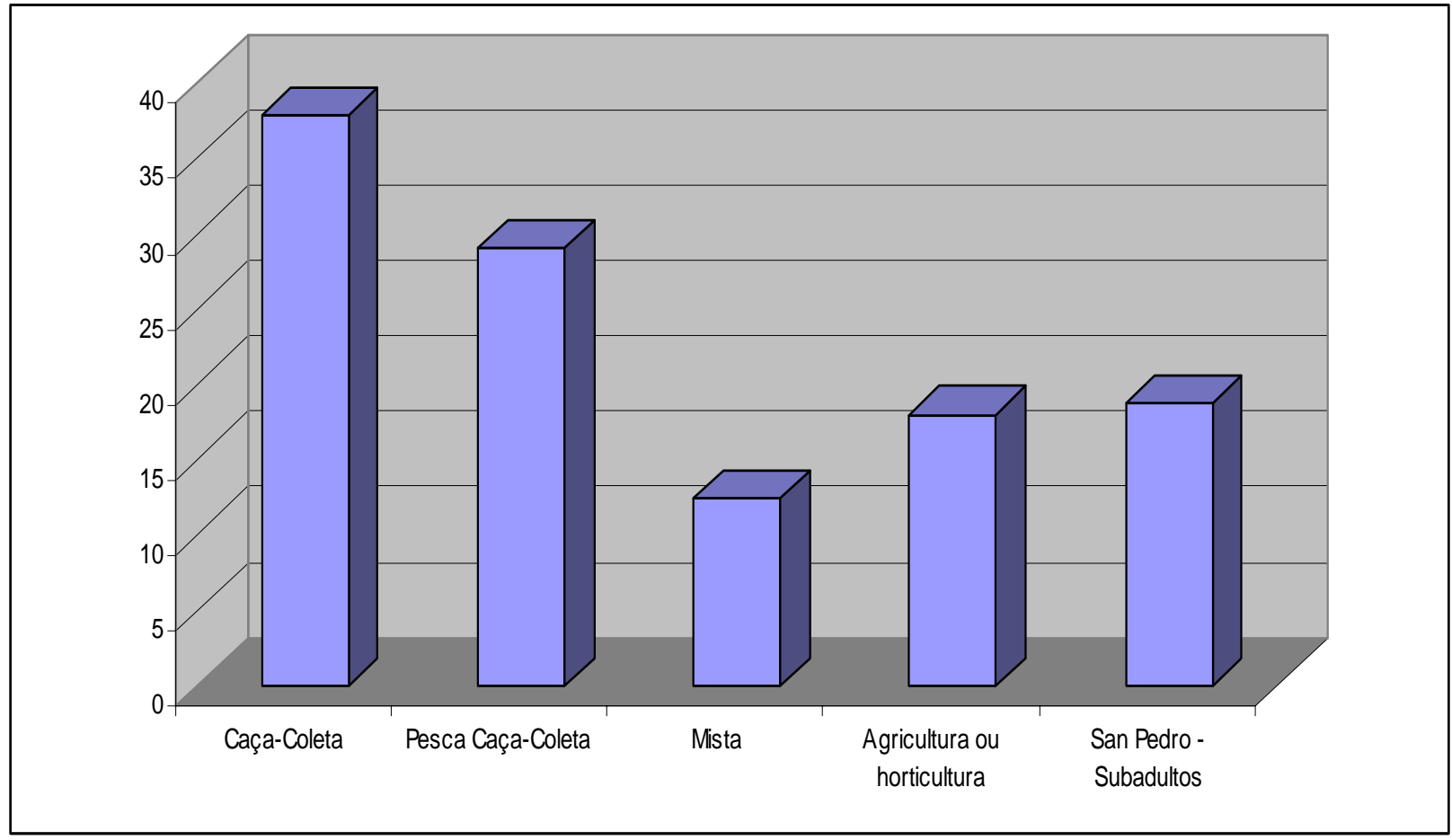

Figura 36 - Comparação entre a porcentagem de indivíduos afetados por abcessos de San Pedro de Atacama e as médias das diferentes estratégias de subsistência. 
A comparação, baseada em alvéolos afetados, mostrou que os subadultos de San Pedro apresentam o menor valor (2,38\%), aproximando-se da média das populações urbanizadas $(3,58)$. As médias das populações das diferentes estratégias de subsistência apresentaram valores bastante próximos, girando entre três e sete por cento (Tabela 64 e Figura 35). Este quadro é confirmado pela ausência de significância do teste KruskalWallis ao comparar as médias das diferentes estratégias de subsistência (Tabela 66).

A comparação direta das freqüências absolutas entre as estratégias de subsistência e os subadultos de San Pedro de Atacama está nas Tabelas 67 e 68. Utilizando indivíduo como unidade, caça-coleta foi a única estratégia de subsistência que apresentou diferença significativa em relação à San Pedro de Atacama; já na análise por alvéolo, os subadultos de San Pedro apresentaram diferença significativa com todos as estratégias de subsistência. A incidência de abcessos nos subadultos de San Pedro é baixa tanto por indivíduo quanto por alvéolo.

A comparação dos abcessos dos subadultos de San Pedro com esqueletos subadultos do restante do mundo (apenas por alvéolo) mostrou que os atacamenhos apresentam alta incidência desse marcador (Tabela 69). Esse resultado contraria a tendência observada na comparação de San Pedro com os adultos, na qual os atacamenhos mostraram baixa incidência de abcessos. É importante frisar que a amostra mundial de subadultos é muito pequena, apresentando apenas um representante de população caçadora-coletora.

\subsection{3 - Cáries}

As cáries na dentição decídua da população subadulta atacamenha apresentam sua primeira ocorrência aos dois anos de idade; até os quatro anos a incidência cresce, atingindo 100\% dos indivíduos entre quatro e dez anos (Tabela 70 e Figura 38). As cáries na dentição permanente seguem um padrão semelhante: dos cinco aos dez anos não existe ocorrência, dos dez aos quinze anos aumenta a incidência e dos quinze aos vinte anos a incidência de indivíduos afetados chega a 100\% (Tabela 71 e Figura 39).

A comparação com as populações mundiais foi feita utilizando-se a dentição permanente, já que ela é o objeto da grande maioria dos estudos sobre cáries. O levantamento bibliográfico está resumido nas Tabelas 72 e 73. Este marcador apresentou a 
Tabela 66 - Valores de P do teste Kruskal-Wallis e dos pós-testes de Dunn, comparando as médias de alvéolos afetados por abcessos nas diferentes estratégias de subsistência.

\begin{tabular}{cc}
\hline$*$ & $P$ \\
\hline Kruskal-Wallis & 0,3923 \\
PCC vs CC & $>0,05$ \\
PCC vs Ag ou Ho & $>0,05$ \\
Ag ou Ho vs CC & $>0,05$ \\
PCC vs. Urb & $>0,05$ \\
PCC vs. Mis & $>0,05$ \\
CC vs. Urb & $>0,05$ \\
CC vs. Mis & $>0,05$ \\
Ag ou Ho vs. Urb & $>0,05$ \\
Ag ou Ho vs. Mis & $>0,05$ \\
Urb vs. Mis & $>0,05$
\end{tabular}

* CC=Caçador-Coletor; PCC=Pescador Caçador-Coletor; Mis=Mista; Ho=Horticultor; Ag = Agricultor; Urb=Urbanizados.

Tabela 67 - Comparação entre as freqüências absolutas (abcessos) das diferentes estratégias de subsistência com San Pedro de Atacama, através do teste Qui-quadrado e Exato de Fisher (indivíduo como unidades de análise).

\begin{tabular}{cccccc}
\hline Estratégia de Subsistência Populações & Frequência absoluta & Porcentagem & Qui-Quadrado (P)* Fisher (P)* \\
\hline Caça-Coleta & 9 & $215 / 417$ & 51,56 & $<0,0001$ & $<0,0001$ \\
Pesca-Caça-Coleta & 5 & $72 / 239$ & 30,13 & 0,0993 & 0,0838 \\
Mista & 1 & $1 / 8$ & 12,50 & 0,6648 & 1,0000 \\
Agricultura ou Horticultura & 4 & $49 / 230$ & 21,30 & 0,7860 & 0,7298 \\
San Pedro de Atacama & & $12 / 64$ & 18,75 & & \\
\hline
\end{tabular}

* os valores em negrito foram considerados significativos

Tabela 68 - Comparação entre as freqüências absolutas (abcessos) das diferentes estratégias de subsistência com San Pedro de Atacama, através do teste Qui-quadrado (avéolo como unidades de análise).

\begin{tabular}{ccccc}
\hline Estratégia de Subsistência & Populações Frequência absoluta Porcentagem Qui-Quadrado (P)* \\
\hline Caça-Coleta & 5 & $458 / 8655$ & 5,29 & $<\mathbf{0 , 0 0 0 1}$ \\
Pesca-Caça-Coleta & 20 & $331 / 9208$ & 3,59 & $\mathbf{0 , 0 4 2 1}$ \\
Mista & 3 & $108 / 2276$ & 4,75 & $\mathbf{0 , 0 0 1 1}$ \\
Agricultura ou Horticultura & 25 & $849 / 16699$ & 5,08 & $<\mathbf{0 , 0 0 0 1}$ \\
Urbano & 4 & $123 / 3223$ & 3,82 & $\mathbf{0 , 0 2 8 2}$ \\
San Pedro de Atacama & & $27 / 1136$ & 2,38 & \\
\hline
\end{tabular}

* os valores em negrito foram considerados significativos 
Tabela 69 - Incidência de abcessos em diferentes populações mundiais subadultas.

\begin{tabular}{ccccccc}
\hline Sítio & Subsistência Datação (BP)/ Período Alveolos & $\%$ & Referências & Faixa etária & Dentição \\
\hline Arcaico & $\mathrm{CC}$ & $4485-2680$ & $0 / 391$ & 0,00 Sciulli e Oberly (2002) & até 16 anos permanente \\
Apurguam, Ilhas Marianas & $\mathrm{Ho}$ & $904-337$ & $0 / 106$ & 0,00 Douglas et al. (1997) até 10 anos decídua \\
Monongahela & $\mathrm{Ag}$ & 550 & $3 / 417$ & 0,72 Sciulli e Oberly (2002) até 16 anos permanente \\
San Pedro - Subadultos & $\mathrm{Ag}$ & $1700-710$ & $27 / 1136$ & 2,38 & até 20 anos & ambas \\
Vila Buffalo & $\mathrm{Ag}$ & $1100-400$ & $9 / 252$ & 3,57 Sciulli e Oberly (2002) até 16 anos permanente \\
Vila Pearson & $\mathrm{Ag}$ & 725 & $1 / 506$ & 0,20 Sciulli e Oberly (2002) até 16 anos permanente \\
Vila Sun Watch & $\mathrm{Ag}$ & 800 & $3 / 258$ & 1,16 Sciulli e Oberly (2002) até 16 anos permanente \\
\hline
\end{tabular}

Tabela 70 - Freqüência absoluta e porcentagem de indivíduos afetados em San Pedro de Atacama por cáries na dentição decídua.

\begin{tabular}{|c|c|c|c|c|c|c|c|c|c|c|}
\hline & \multicolumn{2}{|c|}{ Solcor-3 pre } & \multicolumn{2}{|c|}{ Solcor-3 Tiw } & \multicolumn{2}{|c|}{ Coyo-3 } & \multicolumn{2}{|c|}{ Quitor-6 } & \multicolumn{2}{|c|}{ total } \\
\hline Faixa etária & $\begin{array}{c}\text { Freqüência } \\
\text { absoluta }\end{array}$ & Porcentagem & $\begin{array}{c}\text { Freqüência } \\
\text { absoluta }\end{array}$ & Porcentagem & $\begin{array}{c}\text { Freqüência } \\
\text { absoluta }\end{array}$ & Porcentagem & $\begin{array}{l}\text { Freqüência } \\
\text { absoluta }\end{array}$ & Porcentagem & $\begin{array}{c}\text { Freqüência } \\
\text { absoluta }\end{array}$ & Porcentagem \\
\hline $0-0,9$ & $0 / 6$ & 0,00 & - & - & $0 / 1$ & 0,00 & - & - & $0 / 7$ & 0,00 \\
\hline $1-1,9$ & $0 / 4$ & 0,00 & $0 / 1$ & 0,00 & - & - & - & - & $0 / 5$ & 0,00 \\
\hline $2-2,9$ & $1 / 3$ & 33,33 & $1 / 2$ & 50,00 & $1 / 2$ & 50,00 & - & - & $3 / 7$ & 42,86 \\
\hline $3-3,9$ & $4 / 4$ & 100,00 & $1 / 2$ & 50,00 & $2 / 3$ & 66,66 & $3 / 3$ & 100,00 & $10 / 12$ & 83,33 \\
\hline $4-4,9$ & $1 / 1$ & 100,00 & $2 / 2$ & 100,00 & - & - & $2 / 2$ & 100,00 & $5 / 5$ & 100,00 \\
\hline $5-9,9$ & $2 / 2$ & 100,00 & $1 / 1$ & 100,00 & $1 / 1$ & 100,00 & $1 / 1$ & 100,00 & $5 / 5$ & 100,00 \\
\hline $10-14,9$ & $0 / 1$ & 0,00 & $1 / 1$ & 100,00 & - & - & $1 / 1$ & 100,00 & $2 / 3$ & 66,66 \\
\hline $15-19,9$ & - & - & - & - & - & - & - & - & - & - \\
\hline $0-19,9$ & $8 / 21$ & 38,10 & $6 / 9$ & 66,67 & $4 / 7$ & 57,14 & $7 / 7$ & 100,00 & $25 / 44$ & 56,82 \\
\hline
\end{tabular}


Tabela 71 - Freqüência absoluta e porcentagem de indivíduos afetados em San Pedro de Atacama por cáries na dentição permanente.

\begin{tabular}{|c|c|c|c|c|c|c|c|c|c|c|}
\hline & \multicolumn{2}{|c|}{ Solcor-3 pre } & \multicolumn{2}{|c|}{ Solcor-3 Tiw } & \multicolumn{2}{|r|}{ Coyo-3 } & \multicolumn{2}{|c|}{ Quitor-6 } & \multicolumn{2}{|r|}{ Total } \\
\hline Faixa etária & $\begin{array}{c}\text { Freqüência } \\
\text { absoluta }\end{array}$ & rcentag & $\begin{array}{l}\text { Freqüência } \\
\text { absoluta }\end{array}$ & orcentag & $\begin{array}{r}\text { TFreqüênci } \\
\text { absoluta }\end{array}$ & $\begin{array}{l}\text { cia Porcentage } \\
\text { a }\end{array}$ & $\begin{array}{l}\text { Freqüênci } \\
\text { absoluta }\end{array}$ & orcentag & $\begin{array}{l}\text { Freqüênci } \\
\text { absoluta }\end{array}$ & ia Porcentagem \\
\hline $0-0,9$ & - & - & - & - & - & - & - & - & - & - \\
\hline $2-2,9$ & - & - & - & - & - & - & - & - & - & - \\
\hline $3-3,9$ & - & - & - & - & - & - & - & - & - & - \\
\hline $4-4,9$ & - & - & - & - & - & - & - & - & - & - \\
\hline $10-14,9$ & $4 / 5$ & 80,00 & $1 / 1$ & 100,00 & $0 / 1$ & 0,00 & $2 / 2$ & 100,00 & $7 / 9$ & 77,78 \\
\hline $15-19,9$ & $3 / 3$ & 100,00 & $2 / 2$ & 100,00 & $1 / 1$ & 100,00 & - & - & $6 / 6$ & 100,00 \\
\hline $0-19,9$ & $7 / 10$ & 70,00 & $3 / 3$ & 100,00 & $1 / 2$ & 50,00 & $2 / 3$ & 66,66 & $13 / 18$ & 72,22 \\
\hline
\end{tabular}

Tabela 72 - Levantamento bibliográfico dos estudos que apresentam dados para cáries.

\begin{tabular}{|c|c|c|c|}
\hline Série esqueletal & Subsitência* & Datação (BP)/ Período & Referências \\
\hline Aborígenes australianos & $\mathrm{CC}$ & & Turner II (1979) \\
\hline Aborígenes australianos & $\mathrm{CC}$ & & Turner II (1979) \\
\hline Aborígenes australianos & $\mathrm{CC}$ & População viva & Turner II (1979) \\
\hline Aborígenes tasmanianos & $\mathrm{CC}$ & & Turner II (1979) \\
\hline Aleuts & $\mathrm{CC}$ & $3450-950$ & Keenleyside (1998) \\
\hline Aleuts, Alaska & $\mathrm{CC}$ & & Turner II (1979) \\
\hline Arene Candide/Late Epigravettian, Itália & $\mathrm{CC}$ & 10910+/-09 - 11750 +/-95 (Mesolíticos?) & Formicola (1987) \\
\hline Bellan Bandi Palassa, Sudoeste asiático & $\mathrm{CC}$ & Mesolítico & Lucaks (1992) \\
\hline Central Oregon & $\mathrm{CC}$ & & Hall et al. (1986) \\
\hline Coast of Oregon & $\mathrm{CC}$ & & Hall et al. (1986) \\
\hline Costa sudoeste, África do Sul & $\mathrm{CC}$ & & Sealy et al. (1992) \\
\hline Damdama & $\mathrm{CC}$ & Mesolítico & Lucaks (1996) \\
\hline
\end{tabular}




\begin{tabular}{|c|c|c|c|}
\hline Damdama & $\mathrm{CC}$ & 7000-5000 (Mesolítico) & Lukacs e Pal (1993) \\
\hline Equestrian nomads, EUA & CC? & & Johansson e Owsley (2002) \\
\hline Eskaleut, Ártico & $\mathrm{CC}$ & & Turner II (1979) \\
\hline Eskimos & $\mathrm{CC}$ & $1450-1050 / 550-100$ & Keenleyside (1998) \\
\hline Eskimos, Groelândia & $\mathrm{CC}$ & População viva & Turner II (1979) \\
\hline Furna do Estrago, Pernambuco & $\mathrm{CC}$ & $2000-1000$ & Rodrigues/Mendonça de Souza (1997/1995) \\
\hline Gray Site, Saskatchwan & $\mathrm{CC}$ & 5150 & Turner II (1979) \\
\hline Homo sapiens, Euráfrica & $\mathrm{CC}$ & Paleolítico superior & Turner II (1979) \\
\hline Indian Knoll, Kentucky, EUA & $\mathrm{CC}$ & 4950 & Turner II (1979) \\
\hline Índigenas da Califórnia, EUA & $\mathrm{CC}$ & & Turner II (1979) \\
\hline Klamath Basin, Oregon & $\mathrm{CC}$ & & Hall et al. (1986) \\
\hline Lekhania, Sudoeste asiático & $\mathrm{CC}$ & Mesolítico & Lucaks (1992) \\
\hline Libben, Ohio & CC? & $1150-850$ (Woodland tardio) & Duray (1990) \\
\hline Lower Columbia Valley, Oregon & $\mathrm{CC}$ & & Hall et al. (1986) \\
\hline Mahadaha, Sudoeste asiático & $\mathrm{CC}$ & Mesolítico & Lucaks (1992) \\
\hline Mahadaha, Sudoeste asiático & $\mathrm{CC}$ & Mesolítico & Lukacs e Pal (1993) \\
\hline Mahadaha, Sudoeste asiático & $\mathrm{CC}$ & Mesolítico & Lucaks (1996) \\
\hline Nootka & $\mathrm{CC}$ & & Turner II (1979) \\
\hline Nordeste da Sibéria & $\mathrm{CC}$ & & Turner II (1979) \\
\hline Nubian, Sudão & $\mathrm{CC}$ & Mesolítico & Turner II (1979) \\
\hline NW Coast, Alaska & $\mathrm{CC}$ & & Turner II (1979) \\
\hline Oakhurst & $\mathrm{CC}$ & $10000-4000$ & Sealy et al. (1992) \\
\hline Old Copper, Winsconsin & $\mathrm{CC}$ & $7550 \mathrm{BP}$ & Turner II (1979) \\
\hline Pré-agricultures pré-contato, Georgia, EUA & $\mathrm{CC}$ & $3050-800$ & Larsen et al. (2002) \\
\hline Santa Elena, Equador & $\mathrm{CC}$ & $8250-6600$ & Ubelaker e Newson (2002) \\
\hline Saray Nahar Rai, Sudoeste asiático & $\mathrm{CC}$ & & Lucaks (1992) \\
\hline Sjo-68, Califórnia central & $\mathrm{CC}$ & 2950 & Turner II (1979) \\
\hline Willamette Valley, Oregon & $\mathrm{CC}$ & & Hall et al. (1986) \\
\hline Guam, Ilhas Marianas & PCC & & Hanson e Butler (1997) \\
\hline Ilhas do Havaí & PCC & & Hanson e Butler (1997) \\
\hline Ra el-Hamra, Golfo da Arábia & PCC & $5950-4950$ & Litleton e Frohlich (1993) \\
\hline Rota, Ilhas Marianas & PCC & & Hanson e Butler (1997) \\
\hline Saipan, Ilhas Marianas & PCC & & Hanson e Butler (1997) \\
\hline Sambaqui da Eneseada I PR & PCC & & Wesolowski (2000) \\
\hline
\end{tabular}




\begin{tabular}{|c|c|c|c|}
\hline Sambaqui de Areias Pequenas & PCC & & Wesolowski (2000) \\
\hline Sambaqui de Armação do Sul, Florianópolis & PCC & $2670+/-90$ & Haubert et al. (2004) \\
\hline Sambaqui de Cabeçuda Sítio 1, Santa Catarina & PCC & $4120+/-220$ & Rodrigues (1997) \\
\hline Sambaqui de Cabeçuda Sítio 2, Santa Catarina & PCC & $4120+/-220$ & Rodrigues (1997) \\
\hline Sambaqui de Cabeçuda, Santa Catarina & PCC & $4120+/-220$ & Mello e Alvim e Gomes (1989) \\
\hline Sambaqui de Conquista $n^{\circ} 9$ & PCC & & Wesolowski (2000) \\
\hline Sambaqui de F. Marechal Luz PR & PCC & $4290+/-1230$ & Wesolowski (2000) \\
\hline Sambaqui de Ilha de Espinheiros II & PCC & $2730+/-80$ & Wesolowski (2000) \\
\hline Sambaqui de Laranjeiras I, Santa Catarina & PCC & $3815+/-145$ & Haubert et al. (2004) \\
\hline Sambaqui do Morro do Ouro 2 & PCC & & Wesolowski (2000) \\
\hline Sambaqui do Morro do Ouro I & PCC & $4030+/-40$ & Wesolowski (2000) \\
\hline Sambaqui do Rio Comprido 1 & PCC & $4815-4120$ & Wesolowski (2000) \\
\hline Sambaqui do Rio Comprido 2 & PCC & $4815-4120$ & Wesolowski (2000) \\
\hline Santa Rosa, Ilhas Marianas & PCC & Antigo & Hanson e Butler (1997) \\
\hline Santa Rosa, Ilhas Marianas & PCC & Posterior & Hanson e Butler (1997) \\
\hline Sítio Itararé da Praia de Tapera & $\mathrm{PCC} / \mathrm{Ho} ?$ & $1140+/-180-1030+/-180$ & Haubert et al. (2004) \\
\hline Sítio Itararé de Base Aérea, Florianópolis & $\mathrm{PCC} / \mathrm{Ho} ?$ & $800+/-70$ & Haubert et al. (2004) \\
\hline Sítio Itararé de Cabeçudas, Santa Catarina & $\mathrm{PCC} / \mathrm{Ho} ?$ & & Haubert et al. (2004) \\
\hline Sítio Itararé de Enseada I CR & $\mathrm{PCC} / \mathrm{Ho} ?$ & & Wesolowski (2000) \\
\hline Sítio Itararé de F. Marechal Luz CR & $\mathrm{PCC} / \mathrm{Ho} ?$ & $620+/-100$ & Wesolowski (2000) \\
\hline Sítio Itararé de Itacoara & $\mathrm{PCC} / \mathrm{Ho} ?$ & & Wesolowski (2000) \\
\hline Sítio Itararé de Laranjeiras II, Santa Catarina & $\mathrm{PCC} / \mathrm{Ho} ?$ & & Haubert et al. (2004) \\
\hline Williams Cemetery, Ohio & PCC & $2800+/-45$ & Schneider (1986) \\
\hline Angel Village, Indiana & Mista & 650 & Turner II (1979) \\
\hline Bantu, África do Sul & Mista & & Turner II (1979) \\
\hline Brancos europeus & Mista & Neolítico & Turner II (1979) \\
\hline Dickson Mounds, Indiana & Mista & 650 & Turner II (1979) \\
\hline Failaka, Golfo da Arábia & Mista & $2250-2050$ & Litleton e Frohlich (1993) \\
\hline Galilah, Golfo da Arábia & Mista & 2950-2700 (Idade do Ferro) & Litleton e Frohlich (1993) \\
\hline Jomon, Japão central & Mista & 2950 & Turner II (1979) \\
\hline Mehrgarh - MR3, Sudoeste asiático & Mista & Neolítico & Lucaks (1992) \\
\hline Melanesian, Nova Britania & Mista & & Turner II (1979) \\
\hline Mimbrenos, Novo México & Mista & $<1350$ & Turner II (1979) \\
\hline Negros, Oeste e Sul da África & Mista & & Turner II (1979) \\
\hline
\end{tabular}




\begin{tabular}{|c|c|c|c|}
\hline Oakwood Md., Indiana & Mista & 350 & Turner II (1979) \\
\hline Papuan, Nova Guiné & Mista & População viva & Turner II (1979) \\
\hline Polinésia & Mista & & Turner II (1979) \\
\hline Pukapuka, Polinésia & Mista & População viva & Turner II (1979) \\
\hline Sauk, Illnois & Mista & $150 \mathrm{BP}$ & Turner II (1979) \\
\hline Shimal, Golfo da Arábia & Mista & 3950-3550 (Idade do Bronze) & Litleton e Frohlich (1993) \\
\hline Abu Dhabi - Umm ar Nar, Golfo da Arábia & Past? & $\sim 4450$ & Litleton e Frohlich (1993) \\
\hline Faraoskop & Past? & $2300-1900$ & Sealy et al. (1992) \\
\hline Algodonal, Perú & $\mathrm{Ag}$ & $1150-600$ & Indriati e Buikstra (2001) \\
\hline América do Sul & $\mathrm{Ag}$ & & Turner II (1979) \\
\hline Anderson Village & Ho & $1000-650$ & Schneider (1986) \\
\hline Apurguam, Ilha de Guam & Ho? & $904-337$ & Douglas et al. (1997) \\
\hline Arikara, EUA & $\mathrm{Ag}$ & & Johansson e Owsley (2002) \\
\hline Bahrein, Golfo da Arábia & $A g ?$ & 4250-3750 (Idade do Bronze) & Litleton e Frohlich (1993) \\
\hline Bahrein, Golfo da Arábia & $\mathrm{Ag} ?$ & 2700-2450 (Idade do Ferro) & Litleton e Frohlich (1993) \\
\hline Bahrein, Golfo da Arábia & $\mathrm{Ag} ?$ & 700-450 (Islâmico) & Litleton e Frohlich (1993) \\
\hline Beiliu, China & $\mathrm{Ag}$ & 7000-6000 (Yangshao) & Pechenkina et al. (2002) \\
\hline Brancos europeus & $\mathrm{Ag}$ & Neolítico & Turner II (1979) \\
\hline Brancos europeus & $\mathrm{Ag}$ & Pós-Neolítico & Turner II (1979) \\
\hline Brancos europeus & $\mathrm{Ag}$ & & Turner II (1979) \\
\hline Budakalasz, Hungria & $\mathrm{Ag} ?$ & $4050-3850$ & Molnar e Molnar (1985) \\
\hline Chen-Chen & $\mathrm{Ag}$ & $1150-600$ & Indriati e Buikstra (2001) \\
\hline Chineses & $\mathrm{Ag}$ & População viva & Turner II (1979) \\
\hline Chiribaya Alta & $\mathrm{Ag}$ & $1150-600$ & Indriati e Buikstra (2001) \\
\hline Christian, Nubia & $\mathrm{Ag}$ & & Turner II (1979) \\
\hline Clopton, Inglaterra & $\mathrm{Ag}$ & Idade média & Turner II (1979) \\
\hline Copan rural, Maia & $\mathrm{Ag}$ & $\sim 1150-950$ & Storey et al. (2002) \\
\hline Copan urbano, Maia & $\mathrm{Ag}$ & $\sim 1150-950$ & Storey et al. (2002) \\
\hline Egito & $\mathrm{Ag}$ & 26-30 dinastia & Turner II (1979) \\
\hline Egito & $\mathrm{Ag}$ & & Turner II (1979) \\
\hline Europeus 1 & $\mathrm{Ag}$ & $410-92$ & Ubelaker e Newson (2002) \\
\hline Europeus 2 & $\mathrm{Ag}$ & $280-92$ & Ubelaker e Newson (2002) \\
\hline Europeus 3 & $\mathrm{Ag}$ & $180-10$ & Ubelaker e Newson (2002) \\
\hline França & $\mathrm{Ag}$ & Neolítico & Turner II (1979) \\
\hline
\end{tabular}




\begin{tabular}{|c|c|c|c|}
\hline Gran Quivira, Novo México & $\mathrm{Ag}$ & & Turner II (1979) \\
\hline Grécia & $\mathrm{Ag}$ & 4950 & Turner II (1979) \\
\hline Grécia & $\mathrm{Ag}$ & $3950-2100$ & Turner II (1979) \\
\hline Grécia & $\mathrm{Ag}$ & 650 & Turner II (1979) \\
\hline Grécia & $\mathrm{Ag}$ & População viva & Turner II (1979) \\
\hline Grupo agricultor pré-contato, Georgia, EUA & $\mathrm{Ag}$ & $800-400$ & Larsen et al. (2002) \\
\hline Grupo de contato antigo, Georgia, EUA & $\mathrm{Ag}$ & $400-270$ & Larsen et al. (2002) \\
\hline Grupo de contato posterior, Georgia, EUA & $\mathrm{Ag}$ & $264-248$ & Larsen et al. (2002) \\
\hline Guam, Ilhas Marianas & $\mathrm{Ag}$ & & Pietrosewski et al (1997) \\
\hline Harappa, Paquistão & $\mathrm{Ag}$ & Idade do Bronze & Lucaks (1992) \\
\hline Harappan, Sudoeste asiático & $\mathrm{Ag}$ & Idade do Bronze & Lucaks (1992) \\
\hline Highland pré-históricos, Equador & $\mathrm{Ag}$ & $2950-1500$ & Ubelaker e Newson (2002) \\
\hline Hopi, Old Wapi, Arizona & $\mathrm{Ag}$ & Peublo IV & Turner II (1979) \\
\hline Indian Hills, EUA & Ho & $340+/-100$ & Schneider (1986) \\
\hline Indígenas históricos, EUA & $\mathrm{Ag}$ & $450-300$ & Ubelaker e Newson (2002) \\
\hline Jaina, Maia & $\mathrm{Ag}$ & $1350-950$ & Storey et al. (2002) \\
\hline Japoneses & $\mathrm{Ag}$ & & Turner II (1979) \\
\hline Jiangzhai, China & $\mathrm{Ag}$ & 7000-6000 (Yangshao) & Pechenkina et al. (2002) \\
\hline Kangjia, China & $\mathrm{Ag}$ & 4500-4000 (Longshan) & Pechenkina et al. (2002) \\
\hline Kiskore-Gat, Hungria & $\mathrm{Ag} ?$ & $4950-4550$ & Molnar e Molnar (1985) \\
\hline Kumhar Tekri, Sudoeste asiático & $\mathrm{Ag}$ & Histórico antigo & Lucaks (1992) \\
\hline Mahurjhari, Sudoeste asiático & $\mathrm{Ag}$ & Idade do Ferro & Lucaks (1992) \\
\hline Megalithic, Sudoeste asiático & $\mathrm{Ag}$ & Idade do Ferro & Lucaks (1992) \\
\hline Mehrgarh - MR2 & $\mathrm{Ag} ?$ & Chalcolítico (??) & Lucaks (1996) \\
\hline Meriotic, Nubia & $\mathrm{Ag}$ & & Turner II (1979) \\
\hline Mexicanos & $\mathrm{Ag}$ & & Turner II (1979) \\
\hline Mongoloides & $\mathrm{Ag}$ & & Turner II (1979) \\
\hline Mongoloides, China & $\mathrm{Ag}$ & & Turner II (1979) \\
\hline Mongoloides, China central & $\mathrm{Ag}$ & & Turner II (1979) \\
\hline Negros, África do Sul & $\mathrm{Ag}$ & População viva & Turner II (1979) \\
\hline North Coast, EUA & $\mathrm{Ag}$ & $2550-1550$ & Ubelaker e Newson (2002) \\
\hline Nova Raca, Croácia & $\mathrm{Ag}$ & 650-150 (Medieval tardio) & Turner II (1979) \\
\hline Omaha, EUA & Ho & & Johansson e Owsley (2002) \\
\hline Pachacamac, Peru & $\mathrm{Ag}$ & & Turner II (1979) \\
\hline
\end{tabular}




\begin{tabular}{|c|c|c|c|}
\hline Pawnee, EUA & $\mathrm{Ho}$ & $200-130$ & Johansson e Owsley (2002) \\
\hline Pearson Village & Ho & $540+/-60$ & Schneider (1986) \\
\hline Peruvian, Peru & $\mathrm{Ag}$ & & Turner II (1979) \\
\hline Pitvaros, Hungria & $\mathrm{Ag} ?$ & $2850-2750$ & Molnar e Molnar (1985) \\
\hline Pomparippu, Sudoeste asiático & $\mathrm{Ag}$ & Idade do Ferro & Lucaks (1992) \\
\hline Puebloan, Mancos Canyon & $\mathrm{Ag}$ & $\sim 750 \mathrm{BP}$ & Turner II (1979) \\
\hline Puebloan, Mancos Canyon & $\mathrm{Ag}$ & $\sim 750 \mathrm{BP}$ & Turner II (1979) \\
\hline Puebloan, Nordeste do Arizona & $\mathrm{Ag}$ & Pueblo II & Turner II (1979) \\
\hline Puebloan, Nordeste do Arizona & $\mathrm{Ag}$ & Pueblo III & Turner II (1979) \\
\hline Real Alto, EUA & $\mathrm{Ag}$ & $5350-3450$ & Ubelaker e Newson (2002) \\
\hline Rota, Ilhas Marianas TOTAL & $\mathrm{Ag}$ & & Pietrosewski et al. (1997) \\
\hline Saipan, Ilhas Marianas TOTAL & $\mathrm{Ag}$ & & Pietrosewski et al. (1997) \\
\hline Samad Oasis, Oman & $\mathrm{Ag}$ & 2050-1057 (Idade do Ferro) & Nelson et al. (1999) \\
\hline Sarai Khola, Sudoeste asiático & $\mathrm{Ag}$ & Iron Age & Lucaks (1992) \\
\hline Shijia, China & $\mathrm{Ag}$ & 6000-5000 (Yangshao) & Pechenkina et al. (2002) \\
\hline Site 3 - Ras el Khaimah, Golfo da Arábia & $\mathrm{Ag} ?$ & 2050-1850 & Litleton e Frohlich (1993) \\
\hline Site 5 - Ras el Khaimah, Golfo da Arábia & $\mathrm{Ag} ?$ & $2050-1850$ & Litleton e Frohlich (1993) \\
\hline South Coast, EUA & $\mathrm{Ag}$ & $2850-220$ & Ubelaker e Newson (2002) \\
\hline Sudoeste asiático & $\mathrm{Ag} ?$ & Neo-Chalcolítico & Lucaks (1992) \\
\hline Tape, Hungria & $\mathrm{Ag} ?$ & 2300-2150 (Idade do Bronze) & Molnar e Molnar (1985) \\
\hline Timargaha, Sudoeste asiático & $\mathrm{Ag}$ & Idade do Ferro & Lucaks (1992) \\
\hline Tiszafured-Majoros, Hungria & $\mathrm{Ag} ?$ & $3650-2450$ & Molnar e Molnar (1985) \\
\hline Tiszapolgar-basatanya, Hungria & $\mathrm{Ag} ?$ & $4350-4250$ & Molnar e Molnar (1985) \\
\hline Tristan de Cunha, Atlântico & $\mathrm{Ag}$ & População viva & Turner II (1979) \\
\hline Turpin & $\mathrm{Ho}$ & $775+/-150$ & Schneider (1986) \\
\hline Veszto-Magori Halom, Hungria & $\mathrm{Ag} ?$ & 4850-4450 (Neolítico tardio) & Molnar e Molnar (1985) \\
\hline Xcaret, Maia & $\mathrm{Ag}$ & Pós-Clássico & Storey et al. (2002) \\
\hline X-Group, Nubia & $\mathrm{Ag}$ & & Turner II (1979) \\
\hline Xicun, China & $\mathrm{Ag}$ & 3800-2200 (Western Zhao) & Pechenkina et al. (2002) \\
\hline Yaral & $\mathrm{Ag}$ & $1150-600$ & Indriati e Buikstra (2001) \\
\hline Yayoi, Japão & $\mathrm{Ag}$ & $2150 \mathrm{BP}$ & Turner II (1979) \\
\hline Brancos de Military, East & Urb & $172-74$ & Sledzink e Sandberg (2002) \\
\hline Brancos pobres de Rochester, NY & Urb & $124-87$ & Higgins et al. (2002) \\
\hline Negros de Cedar Groove, Arkansas, EUA & Urb & $50-35$ & Davison et al. (2002) \\
\hline
\end{tabular}


Negros de Freedmans, EUA

Urb

$81-43$

Davison et al. (2002)

* Ag = Agricultor; CC=Caçador-Coletor; Ho=Horticultor; PCC=Pescador-Caçador-Coletor; Urb=Urbanizados; Past=Pastoralistas; ?=dúvida na atribuição do tipo de subsistência.

Tabela 73 - Incidência de cáries em diferentes populações mundiais.

\begin{tabular}{|c|c|c|c|c|c|}
\hline Série esqueletal & Subsitência & Dentes & $\%$ & Individuos & $\%$ \\
\hline Aborígenes australianos & $\mathrm{CC}$ & $61 / 2653$ & 2,30 & & \\
\hline Aborígenes australianos & $\mathrm{CC}$ & $169 / 15561$ & 1,60 & & \\
\hline Aborígenes australianos & $\mathrm{CC}$ & $85 / 1844$ & 4,60 & & \\
\hline Aborígenes tasmanianos & $\mathrm{CC}$ & $35 / 662$ & 5,30 & & \\
\hline Aleuts & $\mathrm{CC}$ & 0/807 & 0,00 & $0 / 57$ & 0,00 \\
\hline Aleuts, Alaska & $\mathrm{CC}$ & $0 / 2000$ & 0,00 & & \\
\hline Arene Candide/Late Epigravettian, Itália & $\mathrm{CC}$ & & & $0 / 6$ & 0,00 \\
\hline Bellan Bandi Palassa, Sudoeste asiático & $\mathrm{CC}$ & $0 / 120$ & 0,00 & & \\
\hline Central Oregon & $\mathrm{CC}$ & & & $5 / 32$ & 15,63 \\
\hline Coast of Oregon & $\mathrm{CC}$ & & & $7 / 39$ & 19,00 \\
\hline Costa sudoeste, África do Sul & $\mathrm{CC}$ & $25 / 948$ & 2,60 & & \\
\hline Damdama & $\mathrm{CC}$ & $7 / 822$ & 0,80 & & \\
\hline Damdama & $\mathrm{CC}$ & & & $5 / 35$ & 14,30 \\
\hline Equestrian nomads, EUA & $\mathrm{CC} ?$ & $60 / 1271$ & 4,71 & & \\
\hline Eskaleut, Ártico & $\mathrm{CC}$ & $2 / 2539$ & 0,08 & & \\
\hline Eskimos & $\mathrm{CC}$ & $1 / 1840$ & 0,05 & $1 / 113$ & 0,88 \\
\hline Eskimos, Groelândia & $\mathrm{CC}$ & $394 / 17917$ & 2,20 & & \\
\hline Furna do Estrago, Pernambuco & $\mathrm{CC}$ & $31 / 334$ & 9,28 & $0 / 18$ & 0,00 \\
\hline Gray Site, Saskatchwan & $\mathrm{CC}$ & $7 / 989$ & 0,70 & & \\
\hline Homo sapiens, Euráfrica & $\mathrm{CC}$ & $5 / 523$ & 1,00 & & \\
\hline Indian Knoll, Kentucky, EUA & $\mathrm{CC}$ & $4 ? / 912$ & 0,40 & & \\
\hline Índigenas da Califórnia, EUA & $\mathrm{CC}$ & $7 / 438$ & 1,60 & & \\
\hline Klamath Basin, Oregon & $\mathrm{CC}$ & & & $14 / 43$ & 32,56 \\
\hline Lekhania, Sudoeste asiático & $\mathrm{CC}$ & $1 / 112$ & 0,89 & & \\
\hline Libben, Ohio & CC? & $109 / 596$ & 18,29 & & \\
\hline Lower Columbia Valley, Oregon & $\mathrm{CC}$ & & & $2 / 32$ & 6,25 \\
\hline Mahadaha, Sudoeste asiático & $\mathrm{CC}$ & $3 / 216$ & 1,20 & & \\
\hline
\end{tabular}




\begin{tabular}{|c|c|c|c|c|c|}
\hline Mahadaha, Sudoeste asiático & $\mathrm{CC}$ & & & $4 / 14$ & 28,60 \\
\hline Mahadaha, Sudoeste asiático & $\mathrm{CC}$ & $3 / 261$ & 1,15 & & \\
\hline Nootka & CC & $0 / 278$ & 0,00 & & \\
\hline Nordeste da Sibéria & $\mathrm{CC}$ & $0 / 76$ & 0,00 & & \\
\hline Nubian, Sudão & $\mathrm{CC}$ & & 1,00 & & \\
\hline NW Coast, Alaska & $\mathrm{CC}$ & $23 / 5500$ & 0,42 & & \\
\hline Oakhurst & $\mathrm{CC}$ & $34 / 192$ & 17,70 & & \\
\hline Old Copper, Winsconsin & $\mathrm{CC}$ & $1 / 232$ & 0,40 & & \\
\hline Pré-agricultures pré-contato, Georgia, EUA & $\mathrm{CC}$ & $30 / 2479$ & 1,21 & & \\
\hline Santa Elena, Brasil & $\mathrm{CC}$ & $12 / 737$ & 1,63 & & \\
\hline Saray Nahar Rai, Sudoeste asiático & $\mathrm{CC}$ & $0 / 114$ & 0,00 & & \\
\hline Sjo-68, Califórnia central & $\mathrm{CC}$ & $7 / 289$ & 2,40 & & \\
\hline Willamette Valley, Oregon & $\mathrm{CC}$ & & & $20 / 46$ & 43,48 \\
\hline Guam, Ilhas Marianas & PCC & $108 / 4143$ & 2,60 & & \\
\hline Ilhas do Havaí & PCC & $1160 / 8292$ & 14,00 & & \\
\hline Ra el-Hamra, Golfo da Arábia & PCC & $0 / 600$ & 0,00 & & \\
\hline Rota, Ilhas Marianas & PCC & $12 / 414$ & 2,90 & & \\
\hline Saipan, Ilhas Marianas & PCC & $52 / 902$ & 5,80 & & \\
\hline Sambaqui da Eneseada I PR & PCC & $1 / 91$ & 1,10 & $1 / 3$ & 33,33 \\
\hline Sambaqui de Areias Pequenas & PCC & $0 / 62$ & 0,00 & & 0,00 \\
\hline Sambaqui de Armação do Sul, Florianópolis & PCC & & 0,00 & & 0,00 \\
\hline Sambaqui de Cabeçuda Sítio 1, Santa Catarina & PCC & & 0,00 & & 0,00 \\
\hline Sambaqui de Cabeçuda Sítio 2, Santa Catarina & PCC & & 0,00 & & 0,00 \\
\hline Sambaqui de Cabeçuda, Santa Catarina & PCC & & 1,30 & & \\
\hline Sambaqui de Conquista $n^{\circ} 9$ & PCC & $0 / 27$ & 0,00 & & 0,00 \\
\hline Sambaqui de F. Marechal Luz PR & PCC & 0/109 & 0,00 & & 0,00 \\
\hline Sambaqui de Ilha de Espinheiros II & PCC & $1 / 133$ & 0,75 & $1 / 7$ & 14,29 \\
\hline Sambaqui de Laranjeiras I, Santa Catarina & PCC & $5 / 607$ & 0,83 & $4 / 39$ & 10,26 \\
\hline Sambaqui do Morro do Ouro 2 & PCC & $37 / 241$ & 8,79 & $12 / 20$ & 60,00 \\
\hline Sambaqui do Morro do Ouro I & PCC & $35 / 288$ & 12,15 & $6 / 14$ & 42,86 \\
\hline Sambaqui do Rio Comprido 1 & PCC & $1 / 64$ & 1,56 & $1 / 3$ & 33,33 \\
\hline Sambaqui do Rio Comprido 2 & PCC & $13 / 140$ & 9,29 & $4 / 7$ & 57,14 \\
\hline Santa Rosa, Ilhas Marianas & PCC & 229/1718 & 13,30 & & \\
\hline Santa Rosa, Ilhas Marianas & PCC & $59 / 934$ & 6,30 & & \\
\hline
\end{tabular}




\begin{tabular}{|c|c|c|c|c|c|}
\hline Sítio Itararé da Praia de Tapera & $\mathrm{PCC} / \mathrm{Ho} ?$ & $11 / 2518$ & 0,44 & 9/115 & 7,83 \\
\hline Sítio Itararé de Base Aérea, Florianópolis & $\mathrm{PCC} / \mathrm{Ho} ?$ & $3 / 840$ & 0,36 & $2 / 63$ & 3,17 \\
\hline Sítio Itararé de Cabeçudas, Santa Catarina & $\mathrm{PCC} / \mathrm{Ho} ?$ & $1 / 688$ & 0,14 & & \\
\hline Sítio Itararé de Enseada I CR & $\mathrm{PCC} / \mathrm{Ho} ?$ & $3 / 391$ & 0,77 & $3 / 20$ & 15,00 \\
\hline Sítio Itararé de F. Marechal Luz CR & $\mathrm{PCC} / \mathrm{Ho} ?$ & $0 / 64$ & 0,00 & & 0,00 \\
\hline Sítio Itararé de Itacoara & $\mathrm{PCC} / \mathrm{Ho} ?$ & $8 / 280$ & 2,86 & $5 / 14$ & 35,71 \\
\hline Sítio Itararé de Laranjeiras II, Santa Catarina & $\mathrm{PCC} / \mathrm{Ho} ?$ & $10 / 1365$ & 0,71 & & \\
\hline Williams Cemetery, Ohio & PCC & $10 / 956$ & 1,05 & & \\
\hline Angel Village, Indiana & Mista & $53 / 513$ & 10,30 & & \\
\hline Bantu, África do Sul & Mista & $91 / 3977$ & 2,30 & & \\
\hline Brancos europeus & Mista & $953 / 29767$ & 3,20 & & \\
\hline Dickson Mounds, Indiana & Mista & $64 / 868$ & 7,40 & & \\
\hline Failaka, Golfo da Arábia & Mista & $11 / 207$ & 5,31 & $6 / 7$ & 85,71 \\
\hline Galilah, Golfo da Arábia & Mista & $3 / 261$ & 1,15 & & \\
\hline Jomon, Japão central & Mista & $118 / 1377$ & 8,60 & & \\
\hline Mehrgarh - MR3, Sudoeste asiático & Mista & $18 / 1272$ & 1,40 & & \\
\hline Melanesian, Nova Britania & Mista & $10 / 2279$ & 0,44 & & \\
\hline Mimbrenos, Novo México & Mista & $50 / 641$ & 7,80 & & \\
\hline Negros, Oeste e Sul da África & Mista & $11 / 1096$ & 1,00 & & \\
\hline Oakwood Md., Indiana & Mista & $15 / 182$ & 8,20 & & \\
\hline Papuan, Nova Guiné & Mista & $234 / 6142$ & 3,81 & & \\
\hline Polinésia & Mista & $20 / 1166$ & 1,70 & & \\
\hline Pukapuka, Polinésia & Mista & 1030/11072 & 9,30 & & \\
\hline Sauk, Illnois & Mista & $11 / 434$ & 2,60 & & \\
\hline Shimal, Golfo da Arábia & Mista & $2 / 43$ & 4,65 & & \\
\hline Abu Dhabi - Umm ar Nar, Golfo da Arábia & Past? & $8 / 327$ & 2,45 & $8 / 37$ & 21,62 \\
\hline Faraoskop & Past? & $12 / 138$ & 8,70 & & \\
\hline Algodonal, Peru & $\mathrm{Ag}$ & $67 / 123$ & 54,50 & & \\
\hline América do Sul & $\mathrm{Ag}$ & $205 / 3295$ & 6,25 & & \\
\hline Anderson Village & Ho & $124 / 1165$ & 10,64 & & \\
\hline Apurguam, Ilha de Guam & Ho? & $33 / 1284$ & 2,60 & & \\
\hline Arikara, EUA & $\mathrm{Ag}$ & $102 / 1609$ & 6,30 & & \\
\hline Bahrain, Golfo da Arábia & $\mathrm{Ag} ?$ & $41 / 308$ & 13,31 & $25 / 51$ & 49,02 \\
\hline Bahrain, Golfo da Arábia & $\mathrm{Ag} ?$ & $85 / 495$ & 17,17 & $11 / 31$ & 35,48 \\
\hline
\end{tabular}




\begin{tabular}{|c|c|c|c|c|c|}
\hline Bahrain, Golfo da Arábia & $\mathrm{Ag} ?$ & $66 / 471$ & 14,01 & $20 / 24$ & 83,33 \\
\hline Beiliu, China & $\mathrm{Ag}$ & $4 / 92$ & 4,35 & & \\
\hline Brancos europeus & $\mathrm{Ag}$ & $98 / 2302$ & 4,26 & & \\
\hline Brancos europeus & $\mathrm{Ag}$ & $9436 / 116500$ & 8,10 & & \\
\hline Brancos europeus & $\mathrm{Ag}$ & $587 / 6104$ & 9,62 & & \\
\hline Budakalasz, Hungria & $\mathrm{Ag} ?$ & $92 / 836$ & 11,00 & $26 / 44$ & 59,09 \\
\hline Chen-Chen & $\mathrm{Ag}$ & 293/695 & 42,10 & & \\
\hline Chineses & $\mathrm{Ag}$ & $444 / 20778$ & 2,14 & & \\
\hline Chiribaya Alta & $\mathrm{Ag}$ & $166 / 366$ & 45,30 & & \\
\hline Christian, Nubia & $\mathrm{Ag}$ & $138 / 932$ & 14,80 & & \\
\hline Clopton, Inglaterra & $\mathrm{Ag}$ & $94 / 790$ & 12,00 & & \\
\hline Copan rural, Maia & $\mathrm{Ag}$ & & 26,00 & & \\
\hline Copan urbano, Maia & $\mathrm{Ag}$ & & 13,00 & & \\
\hline Egito & $\mathrm{Ag}$ & $40 / 1742$ & 2,30 & & \\
\hline Egito & $\mathrm{Ag}$ & $98 / 2219$ & 4,40 & & \\
\hline Europeus 1 & $\mathrm{Ag}$ & $32 / 93$ & 34,41 & & \\
\hline Europeus 2 & $\mathrm{Ag}$ & $28 / 336$ & 8,33 & & \\
\hline Europeus 3 & $\mathrm{Ag}$ & $20 / 124$ & 16,13 & & \\
\hline França & $\mathrm{Ag}$ & $288 / 6869$ & 4,20 & & \\
\hline Gran Quivira, Novo México & $\mathrm{Ag}$ & $276 / 1817$ & 15,20 & & \\
\hline Grécia & $\mathrm{Ag}$ & $32 / 267$ & 12,00 & & \\
\hline Grécia & $\mathrm{Ag}$ & $160 / 2585$ & 6,20 & & \\
\hline Grécia & $\mathrm{Ag}$ & $1012 / 3821$ & 26,50 & & \\
\hline Grécia & $\mathrm{Ag}$ & $148 / 932$ & 15,90 & & \\
\hline Grupo agricultor pré-contato, Georgia, EUA & $\mathrm{Ag}$ & $572 / 5984$ & 9,60 & & \\
\hline Grupo de contato antigo, Georgia, EUA & $\mathrm{Ag}$ & $339 / 4466$ & 7,59 & & \\
\hline Grupo de contato posterior, Georgia, EUA & $\mathrm{Ag}$ & $303 / 1548$ & 19,57 & & \\
\hline Guam, Ilhas Marianas TOTAL & $\mathrm{Ag}$ & $98 / 968$ & 10,10 & & \\
\hline Harappa, Paquistão & $\mathrm{Ag}$ & $51 / 760$ & 6,79 & 17/39 & 43,60 \\
\hline Harappan, Sudoeste asiático & $\mathrm{Ag}$ & $27 / 1501$ & 1,80 & & \\
\hline Highland pré-históricos, Equador & $\mathrm{Ag}$ & $59 / 2283$ & 2,58 & & \\
\hline Hopi, Old Wapi, Arizona & $\mathrm{Ag}$ & $107 / 1707$ & 6,30 & & \\
\hline Indian Hills, EUA & Ho & $72 / 662$ & 10,88 & & \\
\hline Indígenas históricos, EUA & $\mathrm{Ag}$ & $12 / 164$ & 7,32 & & \\
\hline
\end{tabular}




\begin{tabular}{|c|c|c|c|c|c|}
\hline Jaina, Maia & $\mathrm{Ag}$ & & 5,00 & & \\
\hline Japoneses & $\mathrm{Ag}$ & $13825 / 76893$ & 17,98 & & \\
\hline Jiangzhai, China & $\mathrm{Ag}$ & $11 / 418$ & 2,63 & & \\
\hline Kangjia, China & $\mathrm{Ag}$ & $42 / 146$ & 28,77 & & \\
\hline Kiskore-Gat, Hungria & Ag? & $13 / 152$ & 8,55 & $4 / 6$ & 66,66 \\
\hline Kumhar Tekri, Sudoeste asiático & $\mathrm{Ag}$ & 9/431 & 2,09 & & \\
\hline Mahurjhari, Sudoeste asiático & $\mathrm{Ag}$ & 15/196 & 7,65 & & \\
\hline Megalithic, Sudoeste asiático & $\mathrm{Ag}$ & $25 / 1013$ & 2,47 & & \\
\hline Mehrgarh - MR2 & Ag? & $29 / 865$ & 3,40 & & \\
\hline Meriotic, Nubia & $\mathrm{Ag}$ & 20/161 & 12,40 & & \\
\hline Mexicanos & $\mathrm{Ag}$ & $153 / 3298$ & 4,64 & & \\
\hline Mongoloides & $\mathrm{Ag}$ & $33 / 826$ & 4,10 & & \\
\hline Mongoloides, China & $\mathrm{Ag}$ & $9917 / 129634$ & 7,65 & & \\
\hline Mongoloides, China central & $\mathrm{Ag}$ & $2357 / 95830$ & 2,46 & & \\
\hline Negros, África do Sul & $\mathrm{Ag}$ & $1343 / 11680$ & 11,50 & & \\
\hline North Coast, EUA & $\mathrm{Ag}$ & $6 / 507$ & 1,18 & & \\
\hline Nova Raca, Croácia & $\mathrm{Ag}$ & $94 / 864$ & 10,87 & & \\
\hline Omaha, EUA & Ho & $31 / 697$ & 4,40 & & \\
\hline Pachacamac, Peru & $\mathrm{Ag}$ & $422 / 2727$ & 15,50 & & \\
\hline Pawnee, EUA & Ho & $40 / 921$ & 4,30 & & \\
\hline Pearson Village & Ho & $269 / 2772$ & 9,70 & & \\
\hline Peruvian, Peru & $\mathrm{Ag}$ & & 15,40 & & \\
\hline Pitvaros, Hungria & $\mathrm{Ag} ?$ & $9 / 234$ & 3,85 & $2 / 10$ & 20,00 \\
\hline Pomparippu, Sudoeste asiático & $\mathrm{Ag}$ & $4 / 79$ & 5,06 & & \\
\hline Puebloan, Mancos Canyon & $\mathrm{Ag}$ & $22 / 353$ & 6,50 & & \\
\hline Puebloan, Mancos Canyon & $\mathrm{Ag}$ & $13 / 266$ & 4,90 & & \\
\hline Puebloan, Nordeste do Arizona & $\mathrm{Ag}$ & $15 / 225$ & 7,10 & & \\
\hline Puebloan, Nordeste do Arizona & $\mathrm{Ag}$ & $154 / 1027$ & 15,00 & & \\
\hline Real Alto, EUA & $\mathrm{Ag}$ & $38 / 361$ & 10,52 & & \\
\hline Rota, Ilhas Marianas TOTAL & $\mathrm{Ag}$ & $6 / 172$ & 3,50 & & \\
\hline Saipan, Ilhas Marianas TOTAL & $\mathrm{Ag}$ & $53 / 451$ & 11,80 & & \\
\hline Samad Oasis, Oman & $\mathrm{Ag}$ & $26 / 141$ & 18,44 & $11 / 31$ & 35,48 \\
\hline Sarai Khola, Sudoeste asiático & $\mathrm{Ag}$ & $36 / 815$ & 4,41 & & \\
\hline Shijia, China & $\mathrm{Ag}$ & $7 / 179$ & 0,97 & & \\
\hline
\end{tabular}




\begin{tabular}{|c|c|c|c|c|c|}
\hline Site 3 - Ras el Khaimah, Golfo da Arábia & Ag? & $1 / 31$ & 1,20 & & \\
\hline Site 5 - Ras el Khaimah, Golfo da Arábia & Ag? & $7 / 28$ & 25,00 & & \\
\hline South Coast, EUA & $\mathrm{Ag}$ & $107 / 1673$ & 6,40 & & \\
\hline Sudoeste asiático & Ag? & $2 / 567$ & 0,35 & & \\
\hline Tape, Hungria & Ag? & $122 / 832$ & 14,66 & $25 / 30$ & 83,33 \\
\hline Timargaha, Sudoeste asiático & $\mathrm{Ag}$ & $44 / 615$ & 7,15 & & \\
\hline Tiszafured-Majoros, Hungria & Ag? & $46 / 889$ & 5,17 & $14 / 34$ & 41,18 \\
\hline Tiszapolgar-basatanya, Hungria & Ag? & $24 / 594$ & 4,04 & $10 / 28$ & 35,71 \\
\hline Tristan de Cunha, Atlântico & $\mathrm{Ag}$ & $1287 / 4784$ & 26,90 & & \\
\hline Turpin & $\mathrm{Ho}$ & $236 / 953$ & 24,76 & & \\
\hline Veszto-Magori Halom, Hungria & Ag? & $33 / 240$ & 13,75 & $6 / 10$ & 60,00 \\
\hline Xcaret, Maia & $\mathrm{Ag}$ & & 10,00 & & \\
\hline X-Group, Nubia & $\mathrm{Ag}$ & $301 / 2526$ & 11,90 & & \\
\hline Xicun, China & $\mathrm{Ag}$ & $17 / 1006$ & 1,67 & & \\
\hline Yaral & $\mathrm{Ag}$ & $57 / 189$ & 30,10 & & \\
\hline Yayoi, Japão & $\mathrm{Ag}$ & $237 / 1205$ & 19,70 & & \\
\hline Brancos de Military, East & Urb & 298/1865 & 15,98 & & \\
\hline Brancos pobres de Rochester, NY & Urb & $1014 / 3196$ & 31,73 & & \\
\hline Negros de Cedar Groove, Arkansas, EUA & Urb & & & $30 / 36$ & 83,30 \\
\hline Negros de Freedmans, EUA & Urb & & & $491 / 611$ & 81,20 \\
\hline
\end{tabular}

* CC=Caçador-Coletor; PCC=Pescador-Caçador-Coletor; Past=Pastoralistas; Ho=Horticultor; Ag=Agricultor; Urb=Urbanizados; ?=dúvida na atribuição do tipo de subsistência. 


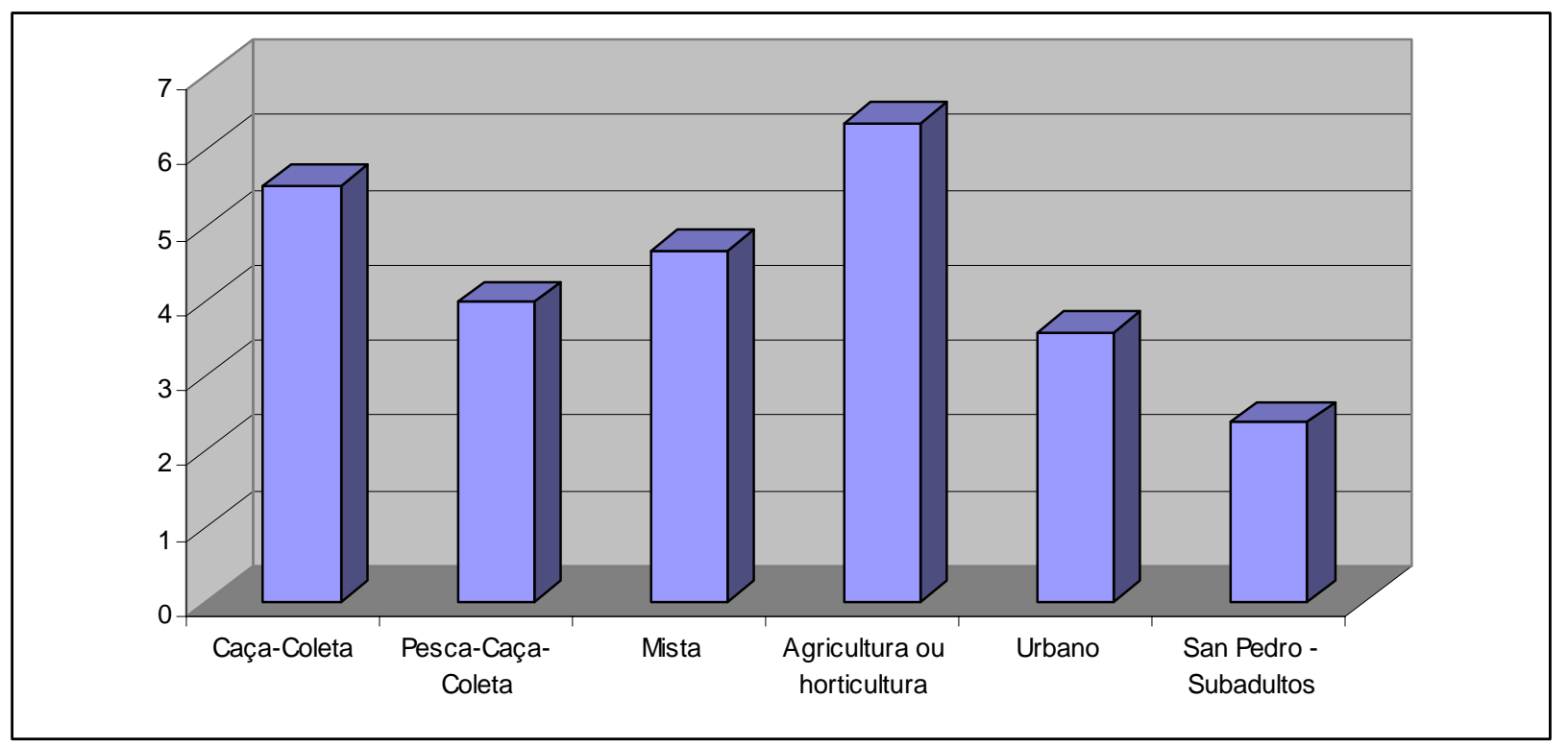

Figura 37 - Comparação entre a porcentagem de alvéolos afetados por abcessos em San Pedro de Atacama e as médias das diferentes estratégias de subsistência.

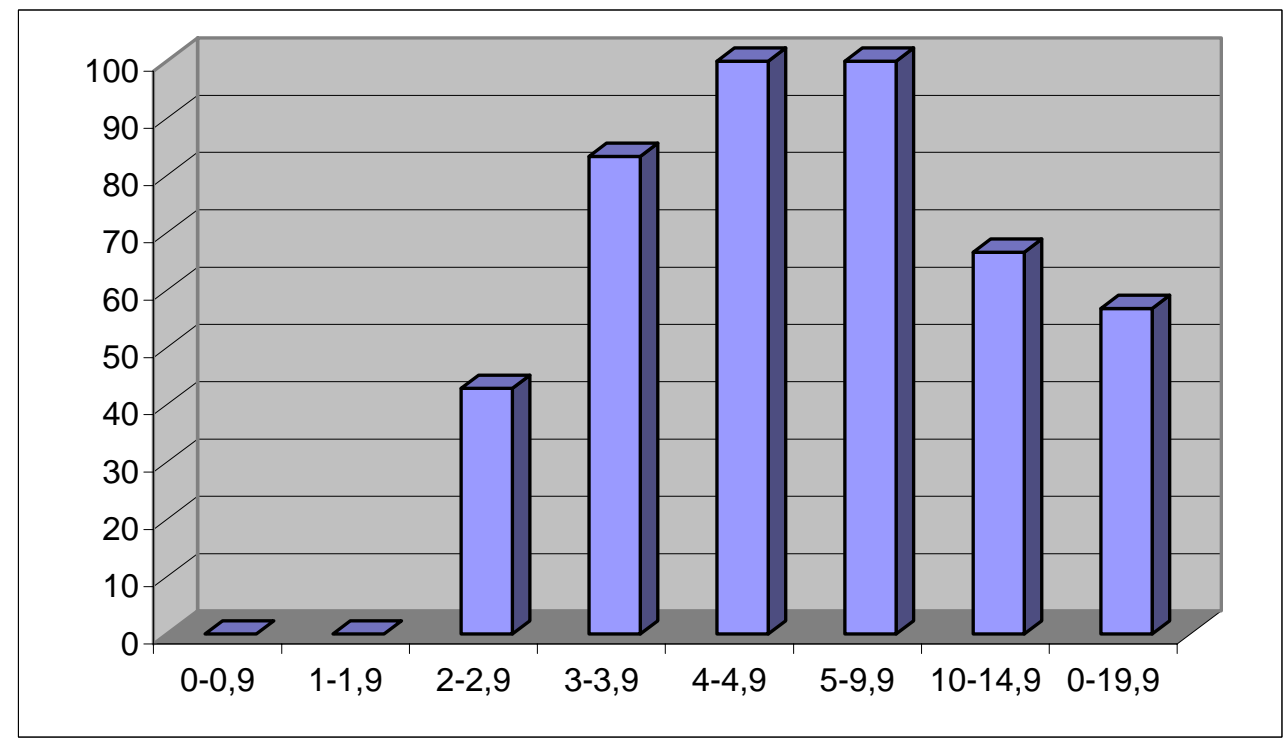

Figura 38 - Distribuição por faixa etária da porcentagem de indivíduos afetados por cáries na dentição decídua em San Pedro de Atacama. 


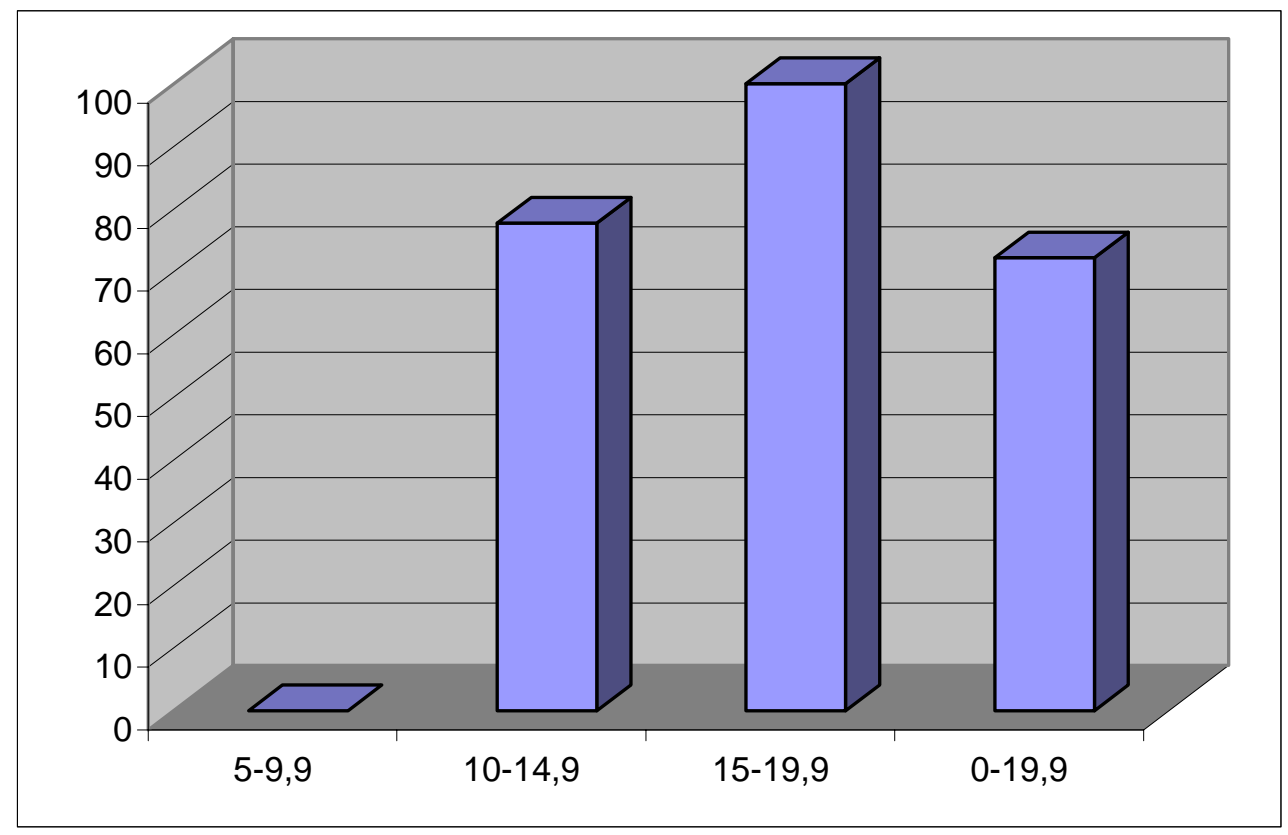

Figura 39 - Distribuição por faixa etária da porcentagem de indivíduos afetados por cáries na dentição permanente em San Pedro de Atacama.

maior quantidade de populações com dados comparáveis: 187. Os dados foram comparados nas categorias dentes afetados e indivíduos afetados.

Os dentes dos subadultos atacamenhos apresentaram uma incidência de cáries (11,98\%) muito próxima à média dos agricultores (11,24\%). Esta proximidade é bastante relevante na medida em que os desvios padrões do restante das estratégias de subsistência não ultrapassam 5\% (com exceção das populações urbanas). Dessa forma, a incidência de cáries de San Pedro está, pelo menos, um desvio padrão distante das médias do restante das estratégias de subsistência (Tabela 74 e Figura 40). O teste Kruskal-Wallis apresentou resultados significativos ao comparar as médias das estratégias de subsistência. Os póstestes de Dunn, no entanto, acusaram diferenças significativas em apenas quatro pares de médias: entre pescadores-caçadores-coletores e agricultores, entre pescadores-caçadorescoletores e urbanizados, entre caçadores-coletores e agricultores, e entre caçadorescoletores e urbanizados (Tabela 75). Esses dados indicam que os dentes cariados são de fato bons marcadores para distinguir diferentes tipos de subsistência (Turner, 1979; Costa et al., 2004). Todas as demais variáveis que afetam a patologia parecem desempenhar um papel pouco significativo frente ao tipo de dieta. 
Tabela 74 - Estatísticas descritivas de cáries nas diferentes subsistências, comparadas com os dados dos subadultos de San Pedro de Atacama.

\begin{tabular}{|c|c|c|c|c|}
\hline & & Dentes & & Individuos \\
\hline \multirow[t]{5}{*}{ Caça-Coleta } & Média & 2,61 & Média & 14,61 \\
\hline & Desv Pad & 4,50 & Desv Pad & 15,07 \\
\hline & Max & 18,29 & $\operatorname{Max}$ & 43,48 \\
\hline & Mínimo & 0,00 & Mínimo & 0,00 \\
\hline & $\mathrm{N}$ & 32 & $\mathrm{~N}$ & 11 \\
\hline \multirow[t]{5}{*}{ Pesca Caça-Coleta } & Média & 3,00 & Média & 17,38 \\
\hline & Desv Pad & 4,35 & Desv Pad & 20,81 \\
\hline & Max & 14,00 & Max & 60,00 \\
\hline & Mínimo & 0,00 & Mínimo & 0,00 \\
\hline & $\mathrm{N}$ & 29 & $\mathrm{~N}$ & 18 \\
\hline \multirow[t]{5}{*}{ Mista } & Média & 4,66 & Média & 85,71 \\
\hline & Desv Pad & 3,30 & Desv Pad & - \\
\hline & Max & 10,30 & Max & 85,71 \\
\hline & Mínimo & 0,44 & Mínimo & 85,71 \\
\hline & $\mathrm{N}$ & 17 & $N$ & 1 \\
\hline \multirow[t]{5}{*}{ Pastoralismo } & Média & 5,58 & Média & 21,62 \\
\hline & Desv Pad & 4,42 & Desv Pad & - \\
\hline & Max & 8,70 & Max & 21,62 \\
\hline & Mínimo & 2,45 & Mínimo & 21,62 \\
\hline & $\mathrm{N}$ & 2 & $N$ & 1 \\
\hline \multirow[t]{5}{*}{ Agricultura ou Horticultura } & Média & 11,24 & Média & 51,07 \\
\hline & Desv Pad & 10,01 & Desv Pad & 19,80 \\
\hline & Max & 54,50 & Max & 83,33 \\
\hline & Mínimo & 0,35 & Mínimo & 20,00 \\
\hline & $\mathrm{N}$ & 91 & $\mathrm{~N}$ & 12 \\
\hline \multirow[t]{5}{*}{ Urbano } & Média & 23,86 & Média & 82,25 \\
\hline & Desv Pad & 11,14 & Desv Pad & 1,48 \\
\hline & $\operatorname{Max}$ & 31,73 & Max & 83,30 \\
\hline & Mínimo & 15,98 & Mínimo & 81,20 \\
\hline & $\mathrm{N}$ & 2 & $\mathrm{~N}$ & $\begin{array}{c}2 \\
13 / 18\end{array}$ \\
\hline San Pedro - Subadultos & & 40/334 (11,98\%) & & $(72,22 \%)$ \\
\hline
\end{tabular}


Tabela 75 - Valores de P do teste Kruskal-Wallis e dos pós-testes de Dunn, comparando as médias de dentes afetados por cáries nas diferentes estratégias de subsistência.

\begin{tabular}{cc}
\hline$\star$ & $\mathrm{P}^{\star \star}$ \\
\hline Kruskal-Wallis & $<\mathbf{0 , 0 0 0 1}$ \\
PCC vs. CC & $>0.05$ \\
PCC vs. Ag ou Ho & $<\mathbf{0 . 0 0 1}$ \\
PCC vs. Urb & $<0.05$ \\
PCC vs. Mis & $>0.05$ \\
PCC vs. Past & $>0.05$ \\
CC vs. Ag ou Ho & $<\mathbf{0 . 0 0 1}$ \\
CC vs. Urb & $<0.05$ \\
CC vs. Mis & $>0.05$ \\
CC vs. Past & $>0.05$ \\
Ag ou Ho vs. Urb & $>0.05$ \\
Ag ou Ho vs. Mis & $>0.05$ \\
Ag ou Ho vs. Past & $>0.05$ \\
Urb vs. Mis & $>0.05$ \\
Urb vs. Past & $>0.05$ \\
Mis vs. Past & $>0.05$ \\
\hline
\end{tabular}

* CC=Caçador-Coletor; PCC=Pescador Caçador-Coletor; Mis=Mista; Past=Pastoralistas; $\mathrm{Ho}=$ Horticultor; Ag=Agricultor; Urb=Urbanizados.

** valores em negrito são significantes. 


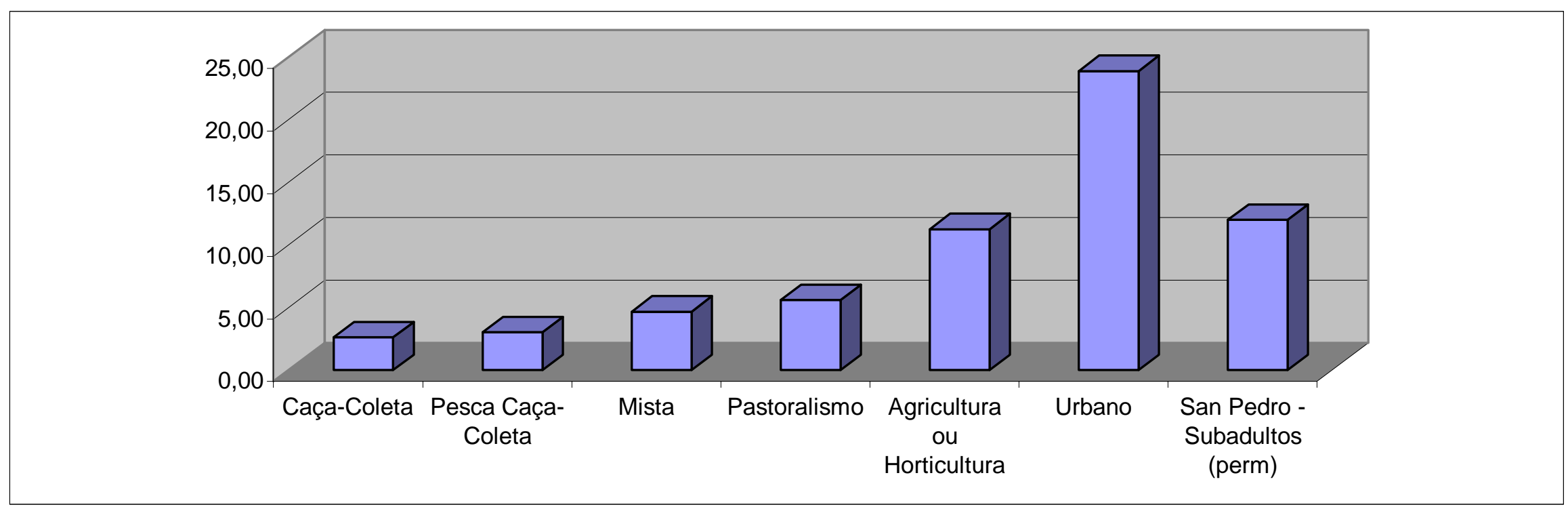

Figura 40 - Comparação entre a porcentagem de dentes afetados por cáries em San Pedro de Atacama (dentição permanente) e as médias das diferentes subsistências. 
A comparação, utilizando indivíduo como unidade, mostrou que os subadultos de San Pedro de Atacama apresentam um alto índice de indivíduos com dentição cariada (72,22\%). Este valor só é menor que a média das populações com subsistência mista (representada por apenas uma população) (85,71\%) e das urbanizadas (82,25\%). A incidência em San Pedro está dentro do desvio padrão da média das populações agricultoras (Tabela 74 e Figura 41). O teste Kruskal-Wallis apresentou diferenças significativas entre as médias das diferentes estratégias de subsistência. Os pós-testes de Dunn apresentaram diferenças significativas em dois pares de médias: pescadores-caçadores-coletores e agricultores, e caçadores-coletores e agricultores (Tabela 76).

A comparação direta das freqüências absolutas de cáries entre San Pedro e as estratégias de subsistência está nas Tabelas 77 e 78. Usando dente como unidade, apenas a população pastoralista não apresentou diferença significativa em comparação com os subadultos de San Pedro; já usando indivíduo como unidade, "urbano” e "agricultor” não apresentaram diferença significativa com San Pedro. A incidência de cáries em San Pedro é alta, sendo maior que em agricultores, mas menor que em populações urbanas.

A incidência de cáries em subadultos no restante do mundo é ligeiramente mais baixa que em adultos, fazendo com que a incidência de cáries nos subadultos de San Pedro seja, comparativamente, ainda maior (Tabela 79). Esses dados reforçam a conclusão de que existe alta incidência de cáries em San Pedro de Atacama. Os agricultores subadultos apresentaram, assim como nos adultos, valores mais próximos aos de San Pedro de Atacama que os caçadores-coletores.

\subsection{4 - Traumas}

A incidência de traumas nos esqueletos subadultos de San Pedro de Atacama é muito baixa. Apenas um dos 89 esqueletos apresentou fratura, localizada na costela direita. Essa única ocorrência é advinda do sítio Quitor-6, e a idade de morte do esqueleto é de 14 anos (Tabela 80 e Figura 42).

A comparação desses dados com populações ao redor do mundo apontou para um baixo índice de traumas em San Pedro de Atacama. O resultado do levantamento bibliográfico encontra-se na Tabela 81 e os resultados das estatísticas descritivas por tipo de subsistência estão na Tabela 82. Essas tabelas mostram que os subadultos de San Pedro 
Tabela 76 - Valores de P do teste Kruskal-Wallis e dos pós-testes de Dunn, comparando as médias de indivíduos afetados por cáries nas diferentes estratégias de subsistência.

\begin{tabular}{cc}
\hline$*$ & $\mathrm{P}^{\star *}$ \\
\hline Kruskal-Wallis & $\mathbf{0 , 0 0 0 1}$ \\
PCC vs. CC & $>0.05$ \\
PCC vs. Ag ou Ho & $<\mathbf{0 . 0 1}$ \\
PCC vs. Urb & $>0.05$ \\
PCC vs. Past & $>0.05$ \\
CC vs. Ag ou Ho & $<\mathbf{0 . 0 1}$ \\
CC vs. Urb & $>0.05$ \\
Ag ou Ho vs. Urb & $>0.05$ \\
Ag ou Ho vs. Past & $>0.05$
\end{tabular}
* CC=Caçador-Coletor; PCC=Pescador Caçador-Coletor; Past=Pastoralistas; Ho=Horticultor; Ag=Agricultor; $\mathrm{Urb}=$ Urbanizados.
** valores em negrito são significantes

Tabela 77 - Comparação entre as freqüências absolutas (cáries) das diferentes estratégias de subsistência com San Pedro de Atacama, através do teste Qui-quadrado e Exato de Fisher (dente como unidade de análise).

\begin{tabular}{cccccc}
\hline Estratégia de Subsistência Populações & Frequência absoluta Porcentagem Qui-Quadrado (P)* Fisher (P)* \\
\hline Caça-Coleta & 31 & $1116 / 63262$ & 1,76 & $<\mathbf{0 , 0 0 1}$ & - \\
Pesca-Caça-Coleta & 25 & $1759 / 25867$ & 6,80 & $\mathbf{0 , 0 0 0 3}$ & - \\
Mista & 18 & $2702 / 61624$ & 4,38 & $<\mathbf{0 , 0 0 0 1}$ & - \\
Pastoralista & 1 & $12 / 138$ & 8,70 & 0,3360 & 0,3823 \\
Agricultura ou Horticultura & 86 & $47407 / 549459$ & 8,63 & $\mathbf{0 , 0 3 7 4}$ & - \\
Urbano & 2 & $1312 / 5061$ & 25,92 & $<\mathbf{0 , 0 0 0 1}$ & - \\
San Pedro de Atacama & & $40 / 334$ & 11,98 & & \\
\hline
\end{tabular}

* os valores em negrito foram considerados significativos

Tabela 78 - Comparação entre as freqüências absolutas (cáries) das diferentes estratégias de subsistência com San Pedro de Atacama, através do teste Qui-quadrado e Exato de Fisher (indivíduo como unidade de análise).

\begin{tabular}{cccccc}
\hline Estratégia de Subsistência Populações & Frequência absoluta Porcentagem Qui-Quadrado (P)* & Fisher (P)* \\
\hline Caça-Coleta & 11 & $58 / 435$ & 13,33 & $<\mathbf{0 , 0 0 0 1}$ & $<\mathbf{0 , 0 0 0 1}$ \\
Pesca-Caça-Coleta & 11 & $48 / 305$ & 15,74 & $<\mathbf{0 , 0 0 0 1}$ & $<\mathbf{0 , 0 0 0 1}$ \\
Mista & 2 & $14 / 44$ & 31,82 & $\mathbf{0 , 0 0 8 5}$ & $\mathbf{0 , 0 0 5 0}$ \\
Agricultura ou Horticultura & 12 & $171 / 338$ & 50,59 & 0,1218 & 0,0913 \\
Urbano & 2 & $521 / 647$ & 80,53 & 0,5665 & 0,3717 \\
San Pedro de Atacama & & $13 / 18$ & 72,22 & & \\
\hline
\end{tabular}

* os valores em negrito foram considerados significativos 
Tabela 79 - Incidência de cáries na dentição permanente em diferentes populações mundiais subadultas.

\begin{tabular}{ccccccc}
\hline Série esqueletal & Subsitência* & Datação (BP)/ Período Dentes & $\%$ & Referências & Faixa etária \\
\hline Arcaico & $\mathrm{CC}$ & $4485-2680$ & $3 / 386$ & 0,78 & Sciulli e Oberly (2002) & até 16 anos \\
Vila Pearson & $\mathrm{Ag}$ & 725 & $21 / 455$ & 4,62 & Sciulli e Oberly (2002) & até 16 anos \\
Vila Sun Watch & $\mathrm{Ag}$ & 800 & $18 / 227$ & 7,93 Sciulli e Oberly (2002) & até 16 anos \\
Monongahela & $\mathrm{Ag}$ & 550 & $23 / 380$ & 6,05 & Sciulli e Oberly (2002) & até 16 anos \\
Vila Buffalo & $\mathrm{Ag}$ & $1100-400$ & $12 / 224$ & 5,36 & Sciulli e Oberly (2002) & até 16 anos \\
San Pedro - Subadultos & & & $40 / 334$ & 11,98 & Até 20 anos \\
\hline
\end{tabular}

* CC=Caçador-Coletor; Ag=Agricultor.

Tabela 80 - Frequiência absoluta e porcentagem de indivíduos em San Pedro de Atacama afetados por traumas.

\begin{tabular}{|c|c|c|c|c|c|c|c|c|c|c|}
\hline & \multicolumn{2}{|c|}{ Solcor-3 pre } & \multicolumn{2}{|c|}{ Solcor-3 Tiw } & \multicolumn{2}{|c|}{ Coyo-3 } & \multicolumn{2}{|c|}{ Quitor-6 } & \multicolumn{2}{|c|}{ Total } \\
\hline \multicolumn{11}{|c|}{ Faixa etáriaFreqüência Porcentagem Freqüência Porcentagem Freqüência Porcentagem Freqüência Porcentagem Freqüência Porcentagem } \\
\hline & absoluta & & absoluta & & Absoluta & & absoluta & & absolut & \\
\hline $0-0,9$ & $0 / 13$ & 0,00 & $0 / 4$ & 0,00 & $0 / 8$ & 0,00 & $0 / 5$ & 0,00 & $0 / 30$ & 0,00 \\
\hline $1-1,9$ & $0 / 6$ & 0,00 & $0 / 2$ & 0,00 & $0 / 1$ & 0,00 & - & - & $0 / 9$ & 0,00 \\
\hline $2-2,9$ & $0 / 6$ & 0,00 & $0 / 3$ & 0,00 & $0 / 3$ & 0,00 & - & - & $0 / 12$ & 0,00 \\
\hline $3-3,9$ & $0 / 3$ & 0,00 & $0 / 2$ & 0,00 & $0 / 3$ & 0,00 & $0 / 3$ & 0,00 & 0/11 & 0,00 \\
\hline $4-4,9$ & $0 / 1$ & 0,00 & $0 / 2$ & 0,00 & - & - & $0 / 2$ & 0,00 & $0 / 5$ & 0,00 \\
\hline $5-9,9$ & $0 / 3$ & 0,00 & $0 / 1$ & 0,00 & $0 / 1$ & 0,00 & $0 / 1$ & 0,00 & $0 / 6$ & 0,00 \\
\hline $10-14,9$ & $0 / 5$ & 0,00 & $0 / 1$ & 0,00 & $0 / 1$ & 0,00 & $1 / 2$ & 50,00 & $1 / 9$ & 11,11 \\
\hline $15-19,9$ & $0 / 4$ & 0,00 & $0 / 2$ & 0,00 & $0 / 1$ & 0,00 & - & - & $0 / 7$ & 0,00 \\
\hline $0-19,9$ & & & & & & & & & $1 / 89$ & 1,12 \\
\hline
\end{tabular}


Tabela 81 - Levantamento bibliográfico dos estudos que apresentam dados para traumas.

\begin{tabular}{cccccc}
\hline Série esqueletal & \multicolumn{2}{c}{ Datação (BP) Subsistência Indivíduos } & $\%$ & Referências \\
\hline Furna do Estrago, Pernambuco & $2000-1000$ & CC & $13 / 25$ & 52,00 & Mendonça de Souza (1995) \\
Sambaqui de Forte Marechal Luz, Santa Catarina & & PCC & $1 / 10$ & 10,00 Silva e Mendonça de Souza (1999) \\
Sambaqui de Jaboticabeiras II, Santa Catarina & & PCC & $1 / 37$ & 2,70 & Storto et al. (1999) \\
Sambaqui de Tarioba, Rio de Janeiro & & PCC & $0 / 17$ & 0,00 & Machado e Sene (2001) \\
Rauns Furnell, Inglaterra & $\sim 1050-850$ & $\mathrm{Ag}$ & $39 / 115$ & 3,50 & Judd e Roberts (1999) \\
San Pedro de Atacama, Chile & & $\mathrm{Ag}$ & $40 / 244$ & 16,93 & Neves et al. (1999) \\
St. Helen-on-the-Walls, Inglaterra & \multirow{2}{*}{$550-400$} & Urb & $29 / 532$ & 5,45 & Grauer e Roberts (1996) \\
Blackfriars, Inglaterra & & Urb? & $9 / 212$ & 4,25 & Grauer e Roberts (1996) \\
Chichester, Inglaterra & & Urb? & $31 / 198$ & 15,66 & Grauer e Roberts (1996) \\
Fishergate, Inglaterra & & Urb? & $2 / 309$ & 6,47 & Grauer e Roberts (1996) \\
St. Nicholas Shambles, Inglaterra & & Urb? & $8 / 161$ & 4,97 & Grauer e Roberts (1996) \\
Whithorn, Inglaterra & & Urb? & $55 / 670$ & 8,21 & Grauer e Roberts (1996) \\
\hline
\end{tabular}

* CC=Caçador-Coletor; PCC=Pescador-Caçador-Coletor; Ag=Agricultor; Urb=Urbanizados.

Tabela 82 - Estatísticas descritivas de traumas em diferentes estratégias de subsistência, comparadas com os dados de subadultos de San Pedro de Atacama.

\begin{tabular}{ccc}
\hline & & Indivíduo \\
\hline Caça-Coleta & Média & $\mathbf{5 2 , 0 0}$ \\
& Desv Pad & - \\
& Max & 52,00 \\
& Mínimo & 52,00 \\
Pesca Caça-Coleta & Média & 1 \\
& Desv Pad & $\mathbf{4 , 2 3}$ \\
& Max & 10,17 \\
& Mínimo & 0,00 \\
& N & 3 \\
Agricultura ou Horticultura & Média & $\mathbf{1 0 , 2 2}$ \\
& & \\
& Desv Pad & 9,50 \\
& Max & 16,93 \\
& Mínimo & 3,50 \\
& $N$ & 2 \\
Urbano & Média & $\mathbf{7 , 5 0}$ \\
& Desv Pad & 4,23 \\
& Max & 15,66 \\
& Mínimo & 4,25 \\
& $N$ & 6 \\
San Pedro - Subadultos & & $1 / 89(\mathbf{1 , 1 2 \% )}$ \\
\hline
\end{tabular}




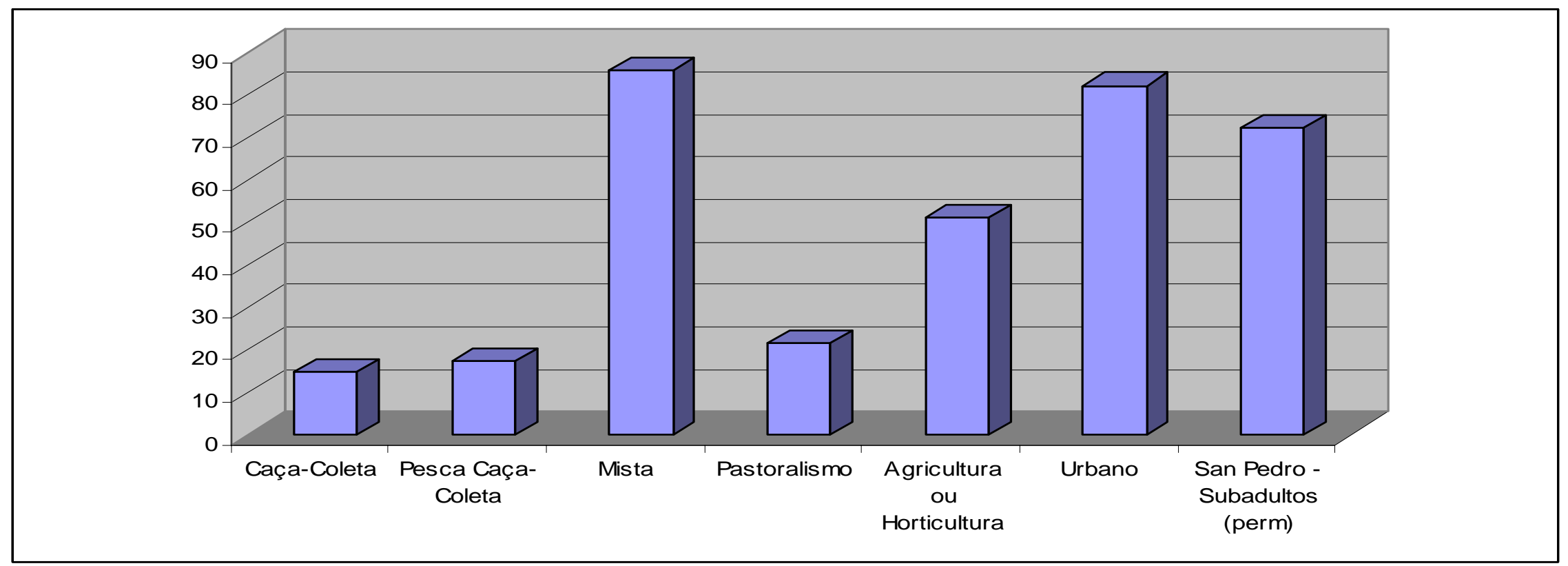

Figura 41 - Comparação entre a porcentagem de indivíduos afetados por cáries em San Pedro de Atacama (dentição permanente) e as médias das diferentes estratégias de subsistência. 


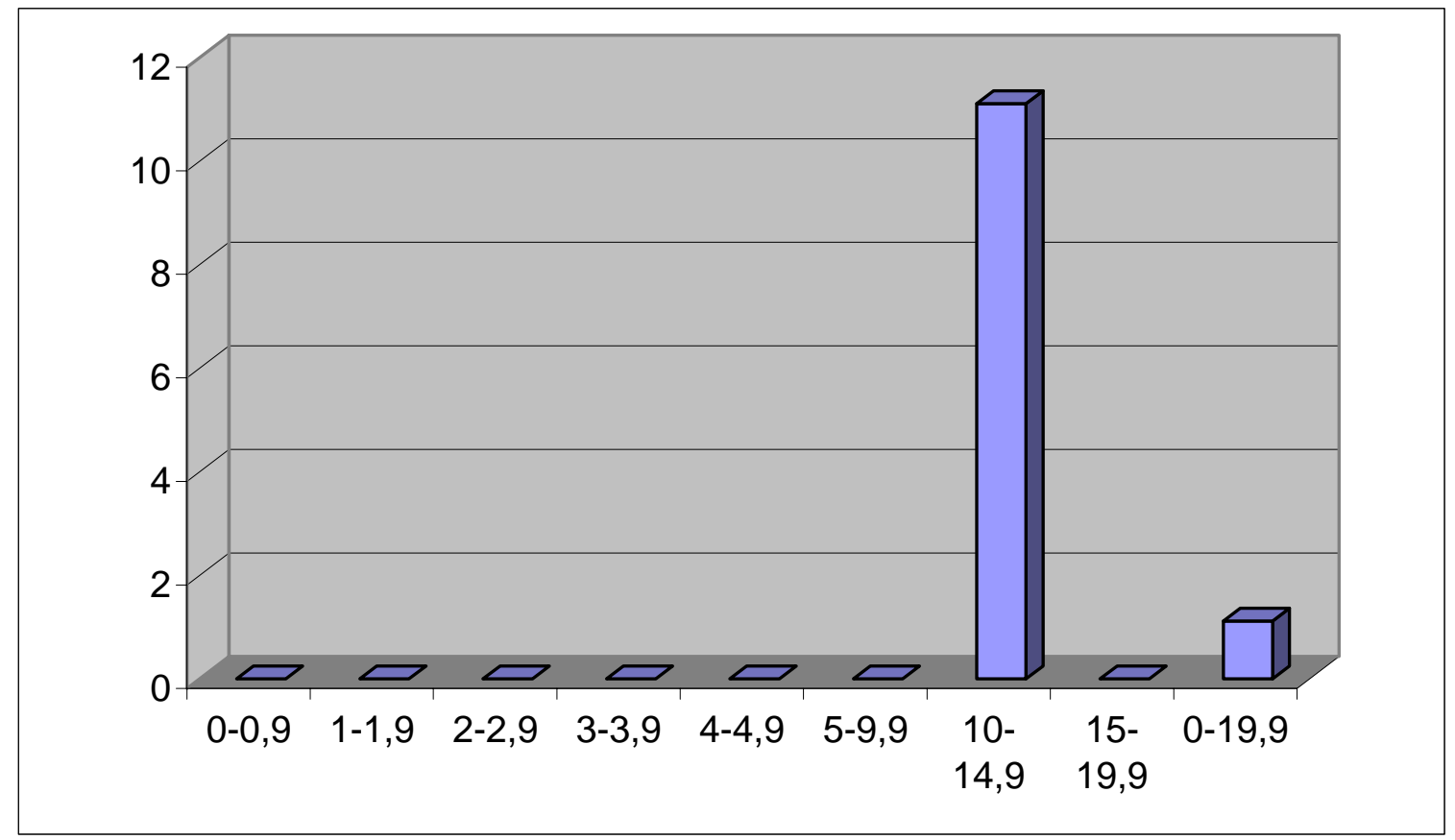

Figura 42 - Distribuição por faixa etária da porcentagem de indivíduos afetados por traumas em San Pedro de Atacama.

de Atacama apresentam a menor incidência de traumas em comparação com as médias das diferentes estratégias de subsistências (Figura 43). A média dos pescadores-caçadorescoletores $(4,23 \%$, desvio padrão 5,17) é a mais próxima do valor de San Pedro; os agricultores, por sua vez, apresentaram uma média um pouco mais alta (10,22\%), porém o desvio padrão é também mais alto $(9,50)$. Os caçadores-coletores apresentaram uma média bastante elevada, com a ressalva que ela é representativa de apenas uma população (Furna do Estrago, Pernambuco). É importante ressaltar que os dados retirados da literatura são de esqueletos adultos.

O teste ANOVA não paramétrico (Kruskal-Wallis) e o pós-teste de Dunn não apresentaram resultados significativos ao comparar as médias de incidência de traumas das diferentes estratégias de subsistência (Tabela 83). O resultado dos caçadores-coletores não foi incluído no teste porque a amostra é constituída por apenas uma população. A comparação direta das freqüências absolutas dos subadultos de San Pedro de Atacama com os diferentes modos de subsistência está na Tabela 84. “Urbano” e 
Tabela 83 - Valores de P do teste Kruskal-Wallis e dos pós-testes de Dunn, comparando as médias de indivíduos afetados por traumas nas diferentes subsistências.

\begin{tabular}{cc}
\hline$\star$ & $\mathrm{P}$ \\
\hline Kruskal-Wallis & 0,5195 \\
PCC vs. Ag ou Ho & $>0.05$ \\
PCC vs. Urb & $>0.05$ \\
Ag ou Ho vs. Urb & $>0.05$ \\
\hline
\end{tabular}

* PCC=Pescador Caçador-Coletor; Ho=Horticultor; Ag = Agricultor; Urb=Urbanizados

Tabela 84 - Comparação entre as freqüências absolutas (traumas) das diferentes estratégias de subsistência com San Pedro de Atacama, através do teste Qui-quadrado e Exato de Fisher (indivíduo como unidade de análise).

\begin{tabular}{|c|c|c|c|c|c|}
\hline \multicolumn{6}{|c|}{ Estratégia de Subsistência Populações Frequência absoluta Porcentagem Qui-Quadrado (P) Fisher (P) } \\
\hline Caça-Coleta & 1 & $13 / 25$ & 52,00 & $<0,0001$ & $<0,0001$ \\
\hline Pesca-Caça-Coleta & 3 & $2 / 64$ & 3,13 & 0,7720 & 0,5718 \\
\hline Agricultura ou Horticultura & 2 & $79 / 359$ & 22,01 & $<0,0001$ & $<0,0001$ \\
\hline Urbano & 6 & $134 / 2082$ & 6,44 & 0,0706 & - \\
\hline San Pedro de Atacama & & $1 / 89$ & 1,12 & & \\
\hline
\end{tabular}

* os valores em negrito foram considerados significativos

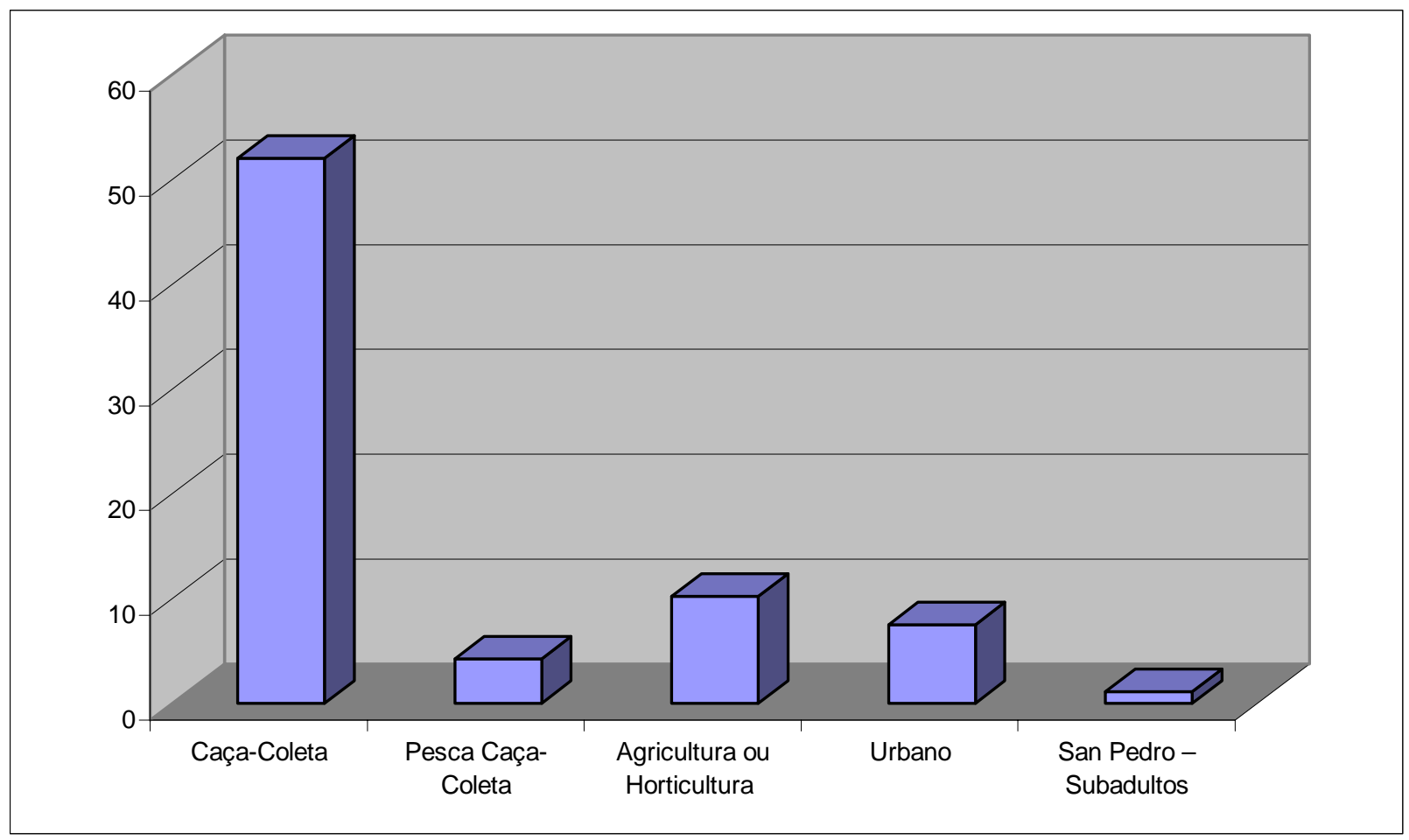

Figura 43 - Comparação entre a porcentagem de indivíduos afetados por traumas em San Pedro de Atacama e as médias das diferentes estratégias de subsistência. 
“pesca-caça-coleta” não apresentaram diferença significativa com San Pedro, enquanto “caça-coleta” e “agricultores” apresentaram diferença significativa. O valor de San Pedro é o mais baixo em comparação às freqüências mundiais. Dados exclusivamente de subadultos não foram encontrados na literatura consultada.

\subsection{5 - Hiperostose porótica}

A incidência de hiperostose porótica na população subadulta de San Pedro de Atacama é de 18,18\%. A primeira aparição deste tipo de lesão ocorre em um esqueleto com seis meses de idade de morte, de Solcor-3 pré-Tiwanaku. A faixa etária que apresenta a maior incidência de indivíduos afetados é a de quinze a vinte anos, seguida pela de cinco a dez anos e pela de dois a três anos (Tabela 85 e Figura 44). A freqüência de cribra orbitalia é um pouco menor (9,68\%) que as lesões na calota craniana (12,73\%). A distribuição pelas faixas etárias também é ligeiramente diferente: cribra apresenta a maior incidência entre quinze e vinte anos, enquanto na calota a incidência é maior entre cinco e dez anos (Tabelas 86 e 87 e Figuras 45 e 46). A primeira aparição de cribra ocorreu em um esqueleto de seis meses de idade, enquanto a primeira aparição na calota ocorreu em um esqueleto de nove meses.

Os dados levantados das populações mundiais estavam divididos em duas categorias: cribra por indivíduo subadulto e hiperostose (cribra mais calota) por indivíduo (subadulto mais adulto) (Tabelas 88 e 89). Os valores de cribra dos subadultos de San Pedro de Atacama foram comparados com a primeira categoria, enquanto os valores de hiperostose (cribra mais calota) da mesma população foram comparados com a segunda categoria.

O valor de cribra para a população subadulta de San Pedro (9,68\%) é o mais baixo em comparação com as médias mundiais das diferentes estratégias de subsistência. A média que mais se aproxima é a das populações com subsistência mista (18,1\%). Porém, é importante destacar que os desvios padrões das médias são todos muito altos (Tabela 90 e Figura 47). O teste não paramétrico Kruskal-Wallis não revelou diferenças significativas ao comparar as médias das diferentes subsistências (Tabela 91). 
Tabela 85 - Freqüência absoluta e porcentagem de indivíduos em San Pedro de Atacama afetados pela hiperostose porótica.

\begin{tabular}{|c|c|c|c|c|c|c|c|c|c|c|}
\hline & \multicolumn{2}{|c|}{ Solcor-3 pre } & \multicolumn{2}{|c|}{ Solcor-3 Tiw } & \multicolumn{2}{|c|}{ Coyo-3 } & \multicolumn{2}{|c|}{ Quitor-6 } & \multicolumn{2}{|c|}{ Total } \\
\hline $\begin{array}{l}\text { Faixa } \\
\text { etária }\end{array}$ & $\begin{array}{c}\text { Freqüência } \\
\text { absoluta }\end{array}$ & Porcentagem & $\begin{array}{c}\text { Freqüência } \\
\text { absoluta }\end{array}$ & Porcentagem & $\begin{array}{c}\text { Freqüência } \\
\text { absoluta }\end{array}$ & Porcentagem & $\begin{array}{c}\text { Freqüência } \\
\text { absoluta }\end{array}$ & Porcentagem & $\begin{array}{c}\text { Freqüência } \\
\text { absoluta }\end{array}$ & Porcentagem \\
\hline $0-0,9$ & $1 / 7$ & 14,29 & $0 / 5$ & 0,00 & $1 / 5$ & 20,00 & $0 / 5$ & 0,00 & $2 / 22$ & 9,09 \\
\hline $1-1,9$ & $0 / 4$ & 0,00 & $0 / 1$ & 0,00 & $0 / 1$ & 0,00 & - & - & $0 / 6$ & 0,00 \\
\hline $2-2,9$ & $0 / 2$ & 0,00 & $1 / 3$ & 33,33 & $1 / 2$ & 50,00 & - & - & $2 / 7$ & 28,57 \\
\hline $3-3,9$ & $1 / 3$ & 33,33 & $0 / 2$ & 0,00 & $0 / 3$ & 0,00 & $1 / 3$ & 33,33 & $2 / 11$ & 18,18 \\
\hline $4-4,9$ & $0 / 1$ & 0,00 & $0 / 1$ & 0,00 & - & - & $0 / 2$ & 0,00 & $0 / 4$ & 0,00 \\
\hline $5-9,9$ & $0 / 1$ & 0,00 & $0 / 1$ & 0,00 & $1 / 1$ & 100,00 & $1 / 1$ & 100,00 & $2 / 4$ & 50,00 \\
\hline $10-14,9$ & $0 / 3$ & 0,00 & $1 / 1$ & 100,00 & $0 / 1$ & 0,00 & $0 / 2$ & 0,00 & $1 / 7$ & 14,29 \\
\hline $15-19,9$ & $1 / 2$ & 50,00 & $1 / 2$ & 50,00 & $1 / 1$ & 100,00 & - & - & $3 / 5$ & 60,00 \\
\hline $0-19,9$ & & & & & & & & & $12 / 66$ & 18,18 \\
\hline
\end{tabular}

Tabela 86 - Freqüência absoluta e porcentagem de indivíduos em San Pedro de Atacama afetados pela cribra orbitalia.

\begin{tabular}{|c|c|c|c|c|c|c|c|c|c|c|}
\hline & \multicolumn{2}{|c|}{ Solcor-3 pre } & \multicolumn{2}{|c|}{ Solcor-3 Tiw } & \multicolumn{2}{|c|}{ Coyo-3 } & \multicolumn{2}{|c|}{ Quitor-6 } & \multicolumn{2}{|c|}{ total } \\
\hline $\begin{array}{l}\text { Faixa } \\
\text { etária }\end{array}$ & $\begin{array}{c}\text { Freqüência } \\
\text { Absoluta }\end{array}$ & Porcentagem & $\begin{array}{l}\text { Freqüência } \\
\text { absoluta }\end{array}$ & Porcentagem & $\begin{array}{c}\text { Freqüência } \\
\text { absoluta }\end{array}$ & Porcentagem & $\begin{array}{c}\text { Freqüência } \\
\text { absoluta }\end{array}$ & Porcentagem & $\begin{array}{c}\text { Freqüência } \\
\text { absoluta }\end{array}$ & Porcentagem \\
\hline $0-0,9$ & $1 / 7$ & 14,29 & $0 / 5$ & 0,00 & $0 / 5$ & 0,00 & $0 / 5$ & 0,00 & $1 / 22$ & 4,55 \\
\hline $1-1,9$ & $0 / 3$ & 0,00 & $0 / 1$ & 0,00 & $0 / 1$ & 0,00 & - & - & $0 / 5$ & 0,00 \\
\hline $2-2,9$ & $0 / 2$ & 0,00 & $1 / 3$ & 33,33 & $1 / 2$ & 50,00 & - & - & $2 / 7$ & 28,57 \\
\hline $3-3,9$ & $0 / 3$ & 0,00 & $0 / 2$ & 0,00 & $0 / 3$ & 0,00 & $1 / 3$ & 33,33 & $1 / 11$ & 9,09 \\
\hline $4-4,9$ & $0 / 1$ & 0,00 & $0 / 1$ & 0,00 & - & - & $0 / 2$ & 0,00 & $0 / 4$ & 0,00 \\
\hline $5-9,9$ & $0 / 1$ & 0,00 & $0 / 1$ & 0,00 & $1 / 1$ & 100,00 & $1 / 1$ & 100,00 & $2 / 4$ & 50,00 \\
\hline $10-14,9$ & $0 / 2$ & 0,00 & $0 / 1$ & 0,00 & $0 / 1$ & 0,00 & $0 / 2$ & 0,00 & $0 / 6$ & 0,00 \\
\hline $15-19,9$ & $0 / 1$ & 0,00 & $0 / 1$ & 0,00 & $0 / 1$ & 0,00 & - & - & $0 / 3$ & 0,00 \\
\hline $0-19,9$ & & & & & & & & & $6 / 62$ & 9,68 \\
\hline
\end{tabular}


Tabela 87 - Freqüência absoluta e porcentagem de indivíduos afetados em San Pedro de Atacama pela hiperostose porótica na calota

\begin{tabular}{|c|c|c|c|c|c|c|c|c|c|c|}
\hline \multirow[b]{2}{*}{$\begin{array}{l}\text { Faixa } \\
\text { etária }\end{array}$} & \multicolumn{2}{|c|}{ Solcor-3 pre } & \multicolumn{2}{|c|}{ Solcor-3 Tiw } & \multicolumn{2}{|c|}{ Coyo-3 } & \multicolumn{2}{|c|}{ Quitor-6 } & \multicolumn{2}{|c|}{ total } \\
\hline & $\begin{array}{l}\text { Freqüência } \\
\text { Absoluta }\end{array}$ & Porcentagem & $\begin{array}{c}\text { Freqüência } \\
\text { absoluta }\end{array}$ & Porcentagem & $\begin{array}{c}\text { Freqüência } \\
\text { absoluta }\end{array}$ & Porcentagem & $\begin{array}{c}\text { Freqüência } \\
\text { absoluta }\end{array}$ & Porcentagem & $\begin{array}{l}\text { Freqüência } \\
\text { absoluta }\end{array}$ & Porcentagem \\
\hline $0-0,9$ & $0 / 4$ & 0,00 & $0 / 4$ & 0,00 & $1 / 3$ & 33,33 & $0 / 5$ & 0,00 & $1 / 16$ & 6,25 \\
\hline $1-1,9$ & $0 / 3$ & 0,00 & $0 / 0$ & 0,00 & $0 / 0$ & 0,00 & - & - & $0 / 3$ & 0,00 \\
\hline $2-2,9$ & $0 / 1$ & 0,00 & $1 / 3$ & 33,33 & $0 / 2$ & 0,00 & - & - & $1 / 6$ & 16,67 \\
\hline $3-3,9$ & $1 / 3$ & 33,33 & $0 / 2$ & 0,00 & $0 / 3$ & 0,00 & $0 / 3$ & 0,00 & $1 / 11$ & 9,09 \\
\hline $4-4,9$ & $0 / 0$ & 0,00 & $0 / 1$ & 0,00 & - & - & $0 / 2$ & 0,00 & $0 / 3$ & 0,00 \\
\hline $5-9,9$ & $0 / 1$ & 0,00 & $0 / 1$ & 0,00 & $0 / 1$ & 100,00 & $0 / 1$ & 0,00 & $0 / 4$ & 0,00 \\
\hline $10-14,9$ & $0 / 3$ & 0,00 & $1 / 1$ & 100,00 & $0 / 1$ & 0,00 & $0 / 2$ & 0,00 & $1 / 7$ & 14,29 \\
\hline $15-19,9$ & $1 / 2$ & 50,00 & $1 / 2$ & 50,00 & $1 / 1$ & 100,00 & - & - & $3 / 5$ & 60,00 \\
\hline $0-19,9$ & & & & & & & & & $7 / 55$ & 12,73 \\
\hline
\end{tabular}

Tabela 88 - Levantamento bibliográfico dos estudos que apresentam dados para hiperostose porótica.

\begin{tabular}{cccc}
\hline Série esqueletal & Subsistencia* & Datação (BP)/Período & Referências \\
\hline Aleuts & CC & $3450-950$ & Keenleyside (1998) \\
Equestrian nomads, EUA & CC & & Johansson e Owsley (2002) \\
Eskimos & CC & $1450-1050 / 550-100$ & Keenleyside (1998) \\
Pré-agricultores pré-contato, EUA & CC & $3050-800$ & Larsen et al. (2002) \\
Santa Elena, Equador & CC & $8250-6600$ & Mellaker e Newson (2002) \\
Acampamento conchífero de Tenório, São Paulo et al. (1991) & PCC & $4930+/-110$ a $620+/-100$ & Wesolowski (2000) \\
Forte Marechal Luz, Santa Catarina & PCC/Ho? & $4930+/-110$ a $620+/-100$ & Mello e Alvim e Uchôa (1996) \\
Indígenas de Sambaquis, São Paulo & PCC & $3950-1875$ & Mello e Alvim et al. (1991) \\
Sambaqui de Cabeçuda, Santa Catarina & PCC & $4930+/-110$ a $620+/-100$ & Storto et al. (1999) \\
Sambaqui deJaboticabeiras II, Santa Catarina & PCC & &
\end{tabular}




\begin{tabular}{|c|c|c|c|}
\hline Sambaquis do Litoral Central de São Paulo & PCC & $4930+/-110$ a $620+/-100$ & Mello e Alvim et al. (1991) \\
\hline Sambaquis do Litoral Sul de São Paulo & PCC & $4930+/-110$ a $620+/-100$ & Mello e Alvim et al. (1991) \\
\hline Pawnee, EUA & Mista & $200-130$ & Johansson e Owsley (2002) \\
\hline Sítios com agricultura não intensiva, México & Mista & $3350-2450$ & Hodges (1987) \\
\hline Agricultores pré-contato, Georgia, EUA & $\mathrm{Ag}$ & $800-400$ & Larsen et al. (2002) \\
\hline Arikara, EUA & $\mathrm{Ag}$ & & Johansson e Owsley (2002) \\
\hline Beiliu & $\mathrm{Ag}$ & 7000-6000 (Yangshao) & Pechenkina et al. (2002) \\
\hline Copan rural, Maia & $\mathrm{Ag}$ & $-1150-950$ & Storey et al. (2002) \\
\hline Copan urbano, Maia & $\mathrm{Ag}$ & $\sim 1150-950$ & Storey et al. (2002) \\
\hline Early contact group, Georgia, EUA & $\mathrm{Ag}$ & $400-270$ & Larsen et al. (2002) \\
\hline Indígenas históricos, EUA & $\mathrm{Ag}$ & $450-300$ & Ubelaker e Newson (2002) \\
\hline Jaina, Maia & $\mathrm{Ag}$ & $1350-950$ & Storey et al. (2002) \\
\hline Jiangzhai, China & $\mathrm{Ag}$ & $7000-6000$ (Yangshao) & Pechenkina et al. (2002) \\
\hline Kangjia, China & $\mathrm{Ag}$ & 4500-4000 (Longshan) & Pechenkina et al. (2002) \\
\hline Late Contact Group, Georgia & $\mathrm{Ag}$ & $264-248$ & Larsen et al. (2002) \\
\hline Mulatos, Sudeste Brasileiro & $\mathrm{Ag} ?$ & & Mello e Alvim e Uchôa (1996) \\
\hline North Coast & $\mathrm{Ag}$ & $2550-1550$ & Ubelaker e Newson (2002) \\
\hline Nova Raca, Croácia & $\mathrm{Ag}$ & $650-150$ & Slaus (2000) \\
\hline Omaha, EUA & $\mathrm{Ho}$ & & Johansson e Owsley (2002) \\
\hline Poundbury Camp, Inglaterra & $\mathrm{Ag}$ & 1500 (Idade do Bronze a Era Saxã) & Stuart-Macadam (1985) \\
\hline Prehistoric Highland, EUA & $\mathrm{Ag}$ & $2950-1500$ & Ubelaker e Newson (2002) \\
\hline Raund Furnells, Inglaterra & $\mathrm{Ag}$ & $1050-750$ & Lewis (2002) \\
\hline Real Alto, EUA & $\mathrm{Ag}$ & $5350-3450$ & Ubelaker e Newson (2002) \\
\hline Shijia, China & $\mathrm{Ag}$ & 6000-5000 (Yangshao) & Pechenkina et al. (2002) \\
\hline Sítios com agricultura intensiva, México & $\mathrm{Ag}$ & $2450-550$ & Hodges (1987) \\
\hline South Coast, EUA & $\mathrm{Ag}$ & $2850-220$ & Ubelaker e Newson (2002) \\
\hline Wharram Percy, Inglaterra & $\mathrm{Ag}$ & $1000-450$ & Lewis (2002) \\
\hline Xcaret, Maia & $\mathrm{Ag}$ & Pós-Clássico & Storey et al. (2002) \\
\hline Xicun, China & $\mathrm{Ag}$ & 3800-2200 (Western Zhao) & Pechenkina et al. (2002) \\
\hline Brancos de Military, East & Urb & $172-74$ & Sledzink e Sandberg (2002) \\
\hline Europeus 1 & Urb & $410-92$ & Ubelaker e Newson (2002) \\
\hline Europeus 2 & Urb & $280-92$ & Ubelaker e Newson (2002) \\
\hline Europeus 3 & Urb & $180-10$ & Ubelaker e Newson (2002) \\
\hline
\end{tabular}




\begin{tabular}{cccc}
\hline London Crypt, Spittafields, Inglaterra & Urb & $221-91$ & Lewis (2002) \\
Monroe County Almshouse, EUA & Urb & $124-87$ & Higgins et al. (2002) \\
Negros de Cedar Groove, Arkansas, EUA & Urb & $50-35$ & Davison et al. (2002) \\
Negros de Freedmans, EUA & Urb & $81-43$ & Davison et al. (2002) \\
Poorhouse de Rochester, NY, EUA & Urb & $124-87$ & Higgins et al. (2002) \\
St. Helen on the Walls, Inglaterra & Urb & $1000-400$ & Lewis (2002) \\
\hline
\end{tabular}

* CC=Caçador-Coletor; PCC=Pescador Caçador-Coletor; Ho=Horticultor; Ag=Agricultor; Urb=Urbanizados; ?=dúvida na atribuição do tipo de subsistência.

Tabela 89 - Incidência de hiperostose porótica em diferentes populações mundiais.

\begin{tabular}{|c|c|c|c|c|c|}
\hline Série esqueletal & Subsistencia* & Criba - Subadultos & $\%$ & Hiperostose & $\%$ \\
\hline Aleuts & CC & & & $0 / 52$ & 0,00 \\
\hline Equestrian nomads, EUA & $\mathrm{CC}$ & $5 / 20$ & 25,00 & $1 / 72$ & 1,39 \\
\hline Eskimos & $\mathrm{CC}$ & & & $4 / 103$ & 3,88 \\
\hline Pré-agricultores pré-contato, EUA & $\mathrm{CC}$ & & & $0 / 113$ & 0,00 \\
\hline Santa Elena, EUA & $\mathrm{CC}$ & & & $0 / 26$ & 0,00 \\
\hline Acampamento conchífero de Tenório, São Paulo & PCC & & & $14 / 23$ & 60,90 \\
\hline Forte Marechal Luz, Santa Catarina & $\mathrm{PCC} / \mathrm{Ho} ?$ & & & $14 / 35$ & 40,00 \\
\hline Indígenas de Sambaquis, São Paulo & PCC & & & $109 / 141$ & 77,30 \\
\hline Sambaqui de Cabeçuda, Santa Catarina & PCC & & & $144 / 155$ & 92,90 \\
\hline Sambaqui deJaboticabeiras II, Santa Catarina & PCC & & & & 5,00 \\
\hline Sambaquis do Litoral Central de São Paulo & PCC & & & $117 / 142$ & 82,40 \\
\hline Sambaquis do Litoral Sul de São Paulo & PCC & & & $32 / 39$ & 82,20 \\
\hline Pawnee, EUA & Mista & $1 / 45$ & 2,90 & $1 / 57$ & 1,75 \\
\hline Sítios com agricultura não intensiva, México & Mista & $6 / 18$ & 33,30 & & \\
\hline Agricultores pré-contato, Georgia, EUA & $\mathrm{Ag}$ & & & $10 / 308$ & 3,30 \\
\hline Arikara, EUA & $\mathrm{Ag}$ & $5 / 35$ & 14,30 & $2 / 85$ & 2,35 \\
\hline Beiliu & $\mathrm{Ag}$ & & & $0 / 6$ & 0,00 \\
\hline Copan rural, Maia & $\mathrm{Ag}$ & & & $25 / 38$ & 65,79 \\
\hline Copan urbano, Maia & $\mathrm{Ag}$ & & & $41 / 169$ & 24,26 \\
\hline Early contact group, Georgia, EUA & $\mathrm{Ag}$ & & & $3 / 32$ & 9,40 \\
\hline Indígenas históricos, EUA & $\mathrm{Ag}$ & & & $0 / 1$ & 0,00 \\
\hline
\end{tabular}




\begin{tabular}{|c|c|c|c|c|c|}
\hline Jaina, Maia & $\mathrm{Ag}$ & & & $17 / 62$ & 27,42 \\
\hline Jiangzhai, China & $\mathrm{Ag}$ & & & $4 / 28$ & 14,29 \\
\hline Kangjia, China & $\mathrm{Ag}$ & & & $5 / 9$ & 55,56 \\
\hline Late Contact Group, Georgia & $\mathrm{Ag}$ & & & $19 / 90$ & 21,10 \\
\hline Mulatos, Sudeste Brasileiro & $\mathrm{Ag} ?$ & & & $154 / 268$ & 57,50 \\
\hline North Coast & $\mathrm{Ag}$ & & & $0 / 19$ & 0,00 \\
\hline Nova Raca, Croácia & $\mathrm{Ag}$ & $17 / 29$ & 58,60 & & \\
\hline Omaha, EUA & Ho & $1 / 45$ & 2,20 & $1 / 61$ & 1,64 \\
\hline Poundbury Camp, Inglaterra & $\mathrm{Ag}$ & & & $53 / 671$ & 7,90 \\
\hline Prehistoric Highland, EUA & $\mathrm{Ag}$ & & & $1 / 12$ & 8,30 \\
\hline Raund Furnells, Inglaterra & $\mathrm{Ag}$ & $46 / 84$ & 55,00 & & \\
\hline Real Alto, EUA & $\mathrm{Ag}$ & & & $0 / 30$ & 0,00 \\
\hline Shijia, China & $\mathrm{Ag}$ & & & $9 / 39$ & 23,08 \\
\hline Sítios com agricultura intensiva, México & $\mathrm{Ag}$ & $11 / 33$ & 33,30 & & \\
\hline South Coast, EUA & $\mathrm{Ag}$ & & & $7 / 31$ & 22,60 \\
\hline Wharram Percy, Inglaterra & $\mathrm{Ag}$ & $112 / 200$ & 56,00 & & \\
\hline Xcaret, Maia & $\mathrm{Ag}$ & & & $9 / 36$ & 25,00 \\
\hline Xicun, China & $\mathrm{Ag}$ & & & $8 / 36$ & 22,22 \\
\hline Brancos de Military, East & Urb & & & $4 / 70$ & 5,70 \\
\hline Europeus 1 & Urb & & & $2 / 19$ & 10,50 \\
\hline Europeus 2 & Urb & & & $0 / 9$ & 0,00 \\
\hline Europeus 3 & Urb & & & $0 / 15$ & 0,00 \\
\hline London Crypt, Spittafields, Inglaterra & Urb & $63 / 111$ & 57,00 & & \\
\hline Monroe County Almshouse, EUA & Urb & $17 / 100$ & 17,00 & & \\
\hline Negros de Cedar Groove, Arkansas, EUA & Urb & $18 / 42$ & 42,86 & $16 / 81$ & 19,75 \\
\hline Negros de Freedmans, EUA & Urb & $16 / 56$ & 28,57 & $37 / 593$ & 6,24 \\
\hline Poorhouse de Rochester, NY, EUA & Urb & $5 / 29$ & 17,24 & & \\
\hline St. Helen on the Walls, Inglaterra & Urb & $49 / 87$ & 56,00 & & \\
\hline
\end{tabular}

* $\overline{\mathrm{CC}}=$ Caçador-Coletor; PCC=Pescador Caçador-Coletor; Ho=Horticultor; Ag = Agricultor; Urb=Urbanizados; ?=dúvida na atribuição do tipo de subsistência. 
Tabela 90 - Estatísticas descritivas de hiperostose porótica nas diferentes estatégias de subsistência, comparadas com os dados dos subadultos de San Pedro de Atacama.

\begin{tabular}{|c|c|c|c|c|}
\hline & & $\begin{array}{c}\text { Cribra - } \\
\text { Subadultos }\end{array}$ & & $\begin{array}{c}\text { Hiperostose } \\
\text { Porótica }\end{array}$ \\
\hline \multirow[t]{5}{*}{ Caça-Coleta } & Média & 25,00 & Média & 1,05 \\
\hline & Desv Pad & - & Desv Pad & 1,69 \\
\hline & Max & 25,00 & Max & 3,88 \\
\hline & Mínimo & 25,00 & Mínimo & 0,00 \\
\hline & $\mathrm{N}$ & 1 & $\mathrm{~N}$ & 5 \\
\hline \multirow[t]{4}{*}{ Pesca Caça-Coleta } & Média & - & Média & 62,96 \\
\hline & Max & - & Max & 92,90 \\
\hline & Mínimo & - & Mínimo & 5,00 \\
\hline & $\mathrm{N}$ & - & $\mathrm{N}$ & 7 \\
\hline \multirow[t]{4}{*}{ Mista } & Média & 18,10 & Média & 1,75 \\
\hline & Desv Pad & 21,50 & Desv Pad & - \\
\hline & Max & 33,30 & Max & 1,75 \\
\hline & Mínimo & 2,90 & Mínimo & 1,75 \\
\hline \multirow[t]{5}{*}{ Agricultura ou Horticultura } & Média & 36,57 & Média & 18,65 \\
\hline & Desv Pad & 24,04 & Desv Pad & 19,76 \\
\hline & Max & 58,60 & Max & 65,79 \\
\hline & Mínimo & 2,20 & Mínimo & 0,00 \\
\hline & $\mathrm{N}$ & 6 & $\mathrm{~N}$ & 21 \\
\hline \multirow[t]{5}{*}{ Urbano } & Média & 36,45 & Média & 7,03 \\
\hline & Desv Pad & 18,19 & Desv Pad & 7,42 \\
\hline & $\operatorname{Max}$ & 57,00 & $\operatorname{Max}$ & 19,75 \\
\hline & Mínimo & 17,00 & Mínimo & 0,00 \\
\hline & $\mathrm{N}$ & 6 & $\mathrm{~N}$ & 6 \\
\hline San Pedro - Subadultos & & $6 / 62(9,68 \%)$ & & $12 / 66(\mathbf{1 8 , 1 8 \% )}$ \\
\hline
\end{tabular}


Tabela 91 - Valores de P do teste Kruskal-Wallis e dos pós-testes de Dunn, comparando as médias de indivíduos afetados por cribra orbitalia nos subadultos das diferentes estratégias de subsistência.

\begin{tabular}{lc}
\hline \multicolumn{1}{c}{${ }^{\star}$} & $\mathrm{P}$ \\
\hline Kruskal-Wallis & 0,5994 \\
Ag ou Ho vs. Mis & $>0.05$ \\
Urb vs. Mis & $>0.05$ \\
Ag ou Ho vs. Urb & $>0.05$ \\
\hline
\end{tabular}

* Mis=Mista; Ho=Horticultor; Ag=Agricultor; Urb=Urbanizados.

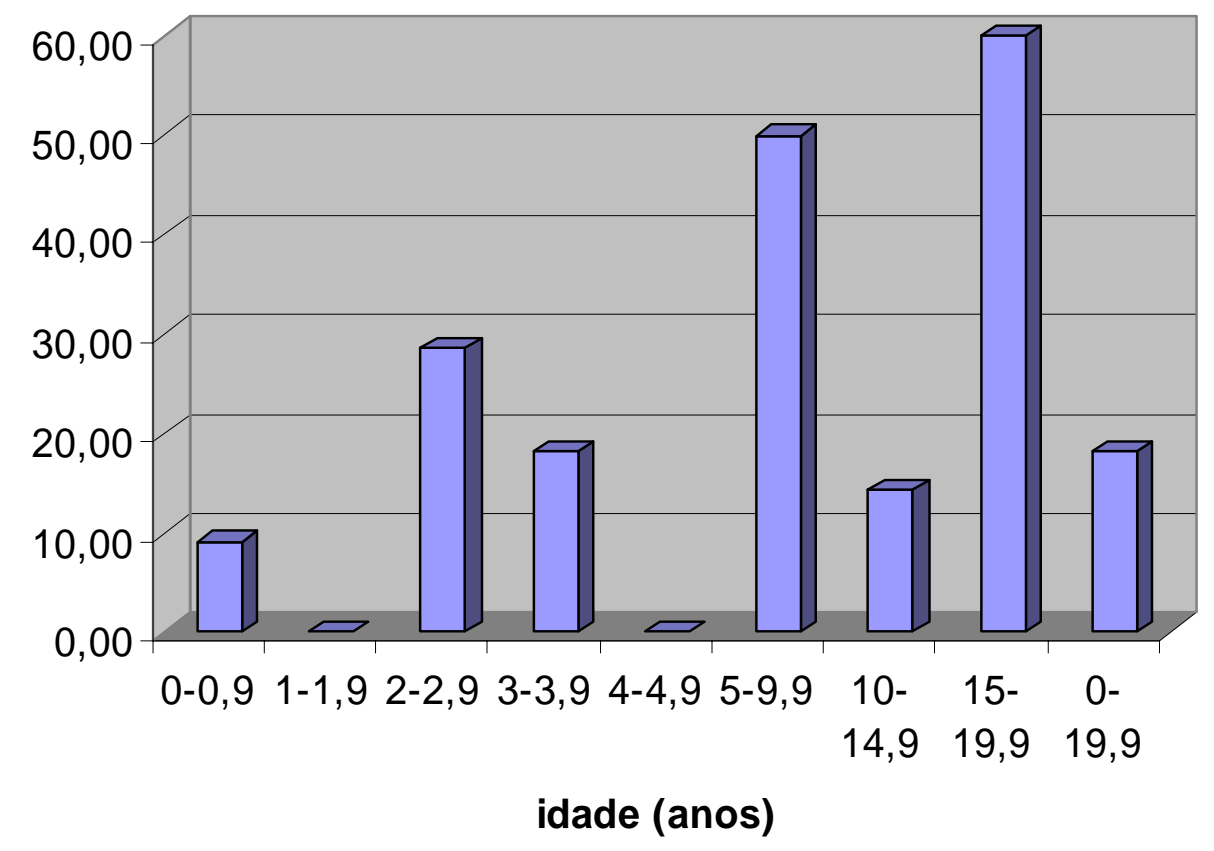

Figura 44 - Distribuição por faixa etária da porcentagem de indivíduos afetados por hiperostose porótica em San Pedro de Atacama. 


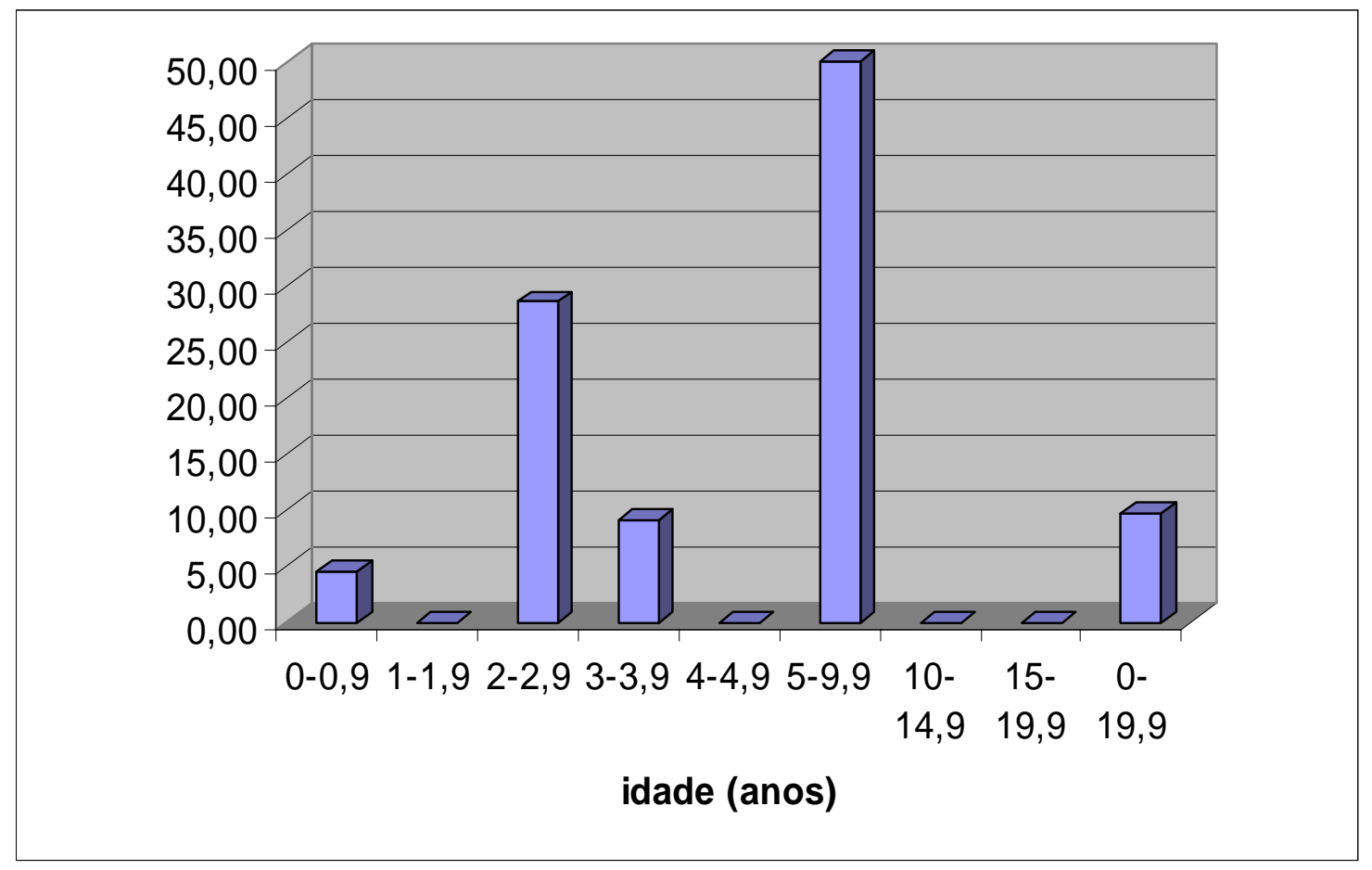

Figura 45 - Distribuição por faixa etária da porcentagem de indivíduos afetados por cribra orbitalia em San Pedro de Atacama.

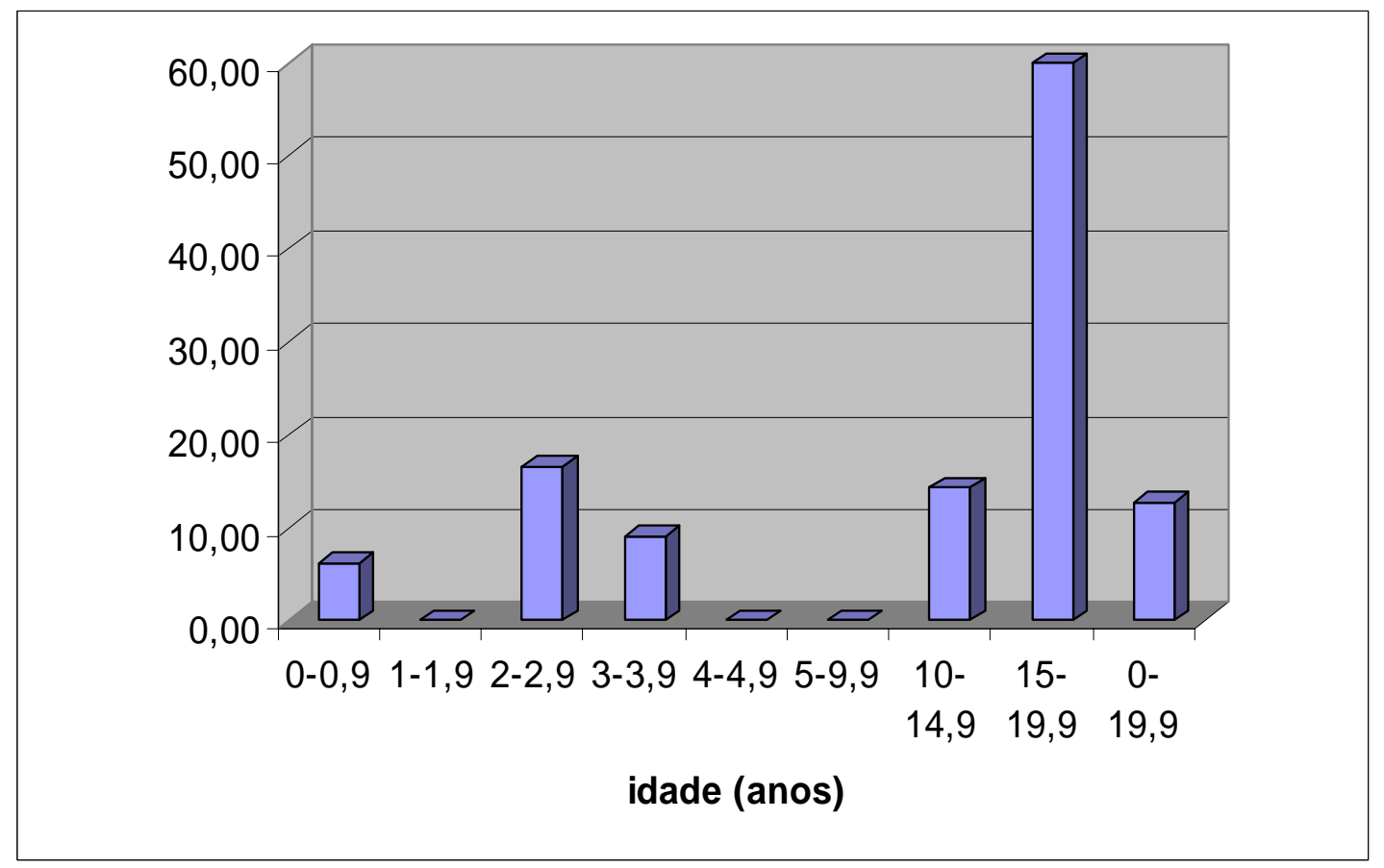

Figura 46 - Distribuição por faixa etária da porcentagem de indivíduos afetados por hiperostose porótica na calota em San Pedro de Atacama. 


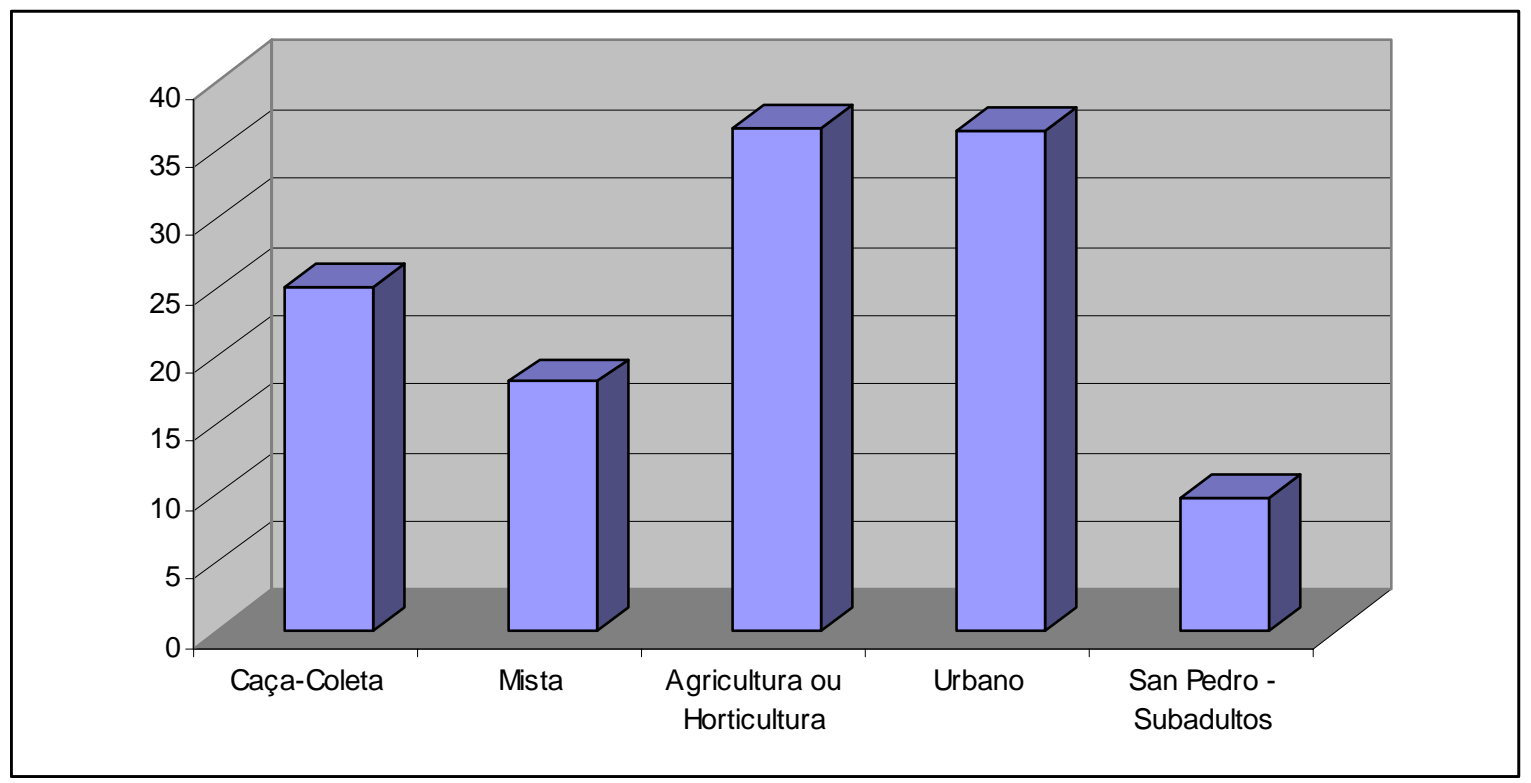

Figura 47 - Comparação entre a porcentagem de indivíduos afetados por cribra orbitalia dos subadultos em San Pedro de Atacama e as médias dos indivíduos subadultos das diferentes subsistências.

A incidência de hiperostose nos esqueletos subadultos de San Pedro de Atacama $(18,18 \%)$ é muito próxima da média das populações agricultoras $(18,65 \%)$. Nas demais estratégias de subsistência é menor que esse valor, com exceção dos pescadores-caçadorescoletores (62,96\%) (Tabela 90 e Figura 48). O teste Kruskal-Wallis apresentou resultado significativo ao comparar as médias dos diferentes modos de subsistência. Os pós-testes de Dunn, porém, só apresentaram resultado significativo para a comparação entre pescadorescaçadores-coletores e caçadores-coletores (Tabela 92).

A comparação direta das freqüências absolutas entre os subadultos de São Pedro de Atacama e as estratégias de subsistência está nas Tabelas 93 e 94. Para cribra em subadultos, "mista” e "caçador-coletor" não apresentaram diferença significativa com San Pedro; enquanto para hiperostose porótica, San Pedro não apresentou diferença significativa em relação aos agricultores. 
Tabela 92 - Valores de P do teste Kruskal-Wallis e dos pós-testes de Dunn, comparando as médias de indivíduos afetados por hiperostose porótica das diferentes estratégias de subsistência.

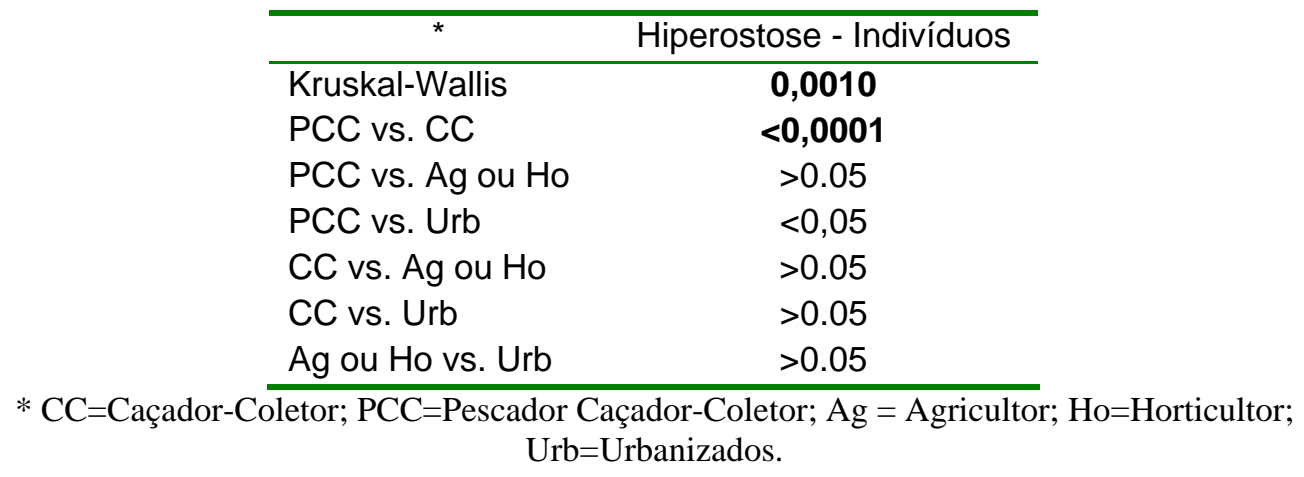

Tabela 93 - Comparação entre as freqüências absolutas (cribra orbitalia em subadultos) das diferentes estratégias de subsistência com San Pedro de Atacama, através do teste Quiquadrado e Exato de Fisher (indivíduo como unidade de análise).

\begin{tabular}{cccccc}
\hline \multicolumn{5}{c}{ Estratégia de Subsistência Populações Freqüência absoluta } & Porcentagem Qui-Quadrado (P)* Fisher (P)* \\
\hline Caça-Coleta & 1 & $5 / 20$ & 25,00 & 0,1704 & 0,1257 \\
Mista & 2 & $7 / 63$ & 11,11 & 0,7929 & 1,0000 \\
Agricultura ou Horticultura & 6 & $192 / 426$ & 45,07 & $<\mathbf{0 , 0 0 0 1}$ & $<\mathbf{0 , 0 0 0 1}$ \\
Urbano & 6 & $168 / 425$ & 39,53 & $<\mathbf{0 , 0 0 0 1}$ & $<\mathbf{0 , 0 0 0 1}$ \\
San Pedro de Atacama & & $6 / 62$ & 9,68 & & \\
\hline
\end{tabular}

* os valores em negrito foram considerados significativos

Tabela 94 - Comparação entre as freqüências absolutas (hiperostose porótica) das diferentes estratégias de subsistência com San Pedro de Atacama, através do teste Quiquadrado e Exato de Fisher (indivíduo como unidade de análise).

\begin{tabular}{cccccc}
\hline Estratégia de Subsistência Frequência absoluta Porcentagem & Qui-Quadrado (P) Fisher (P) Populações \\
\hline Caça-Coleta & $5 / 366$ & 1,37 & $<\mathbf{0 0 0 0 1}$ & $<\mathbf{0 , 0 0 0 1}$ & 5 \\
Pesca-Caça-Coleta & $430 / 535$ & 80,37 & $<\mathbf{0 , 0 0 0 1}$ & $<\mathbf{0 , 0 0 0 1}$ & 6 \\
Mista & $1 / 57$ & 1,75 & $\mathbf{0 , 0 0 7 8}$ & $\mathbf{0 , 0 0 2 9}$ & 1 \\
Agricultura ou Horticultura & $368 / 2031$ & 18,12 & 0,9896 & - & 11 \\
Urbano & $59 / 787$ & 7,50 & $\mathbf{0 , 0 0 5 3}$ & $\mathbf{0 , 0 0 8 1}$ & 6 \\
San Pedro de Atacama & $12 / 66$ & 18,18 & & & \\
\hline
\end{tabular}

* os valores em negrito foram considerados significativos 


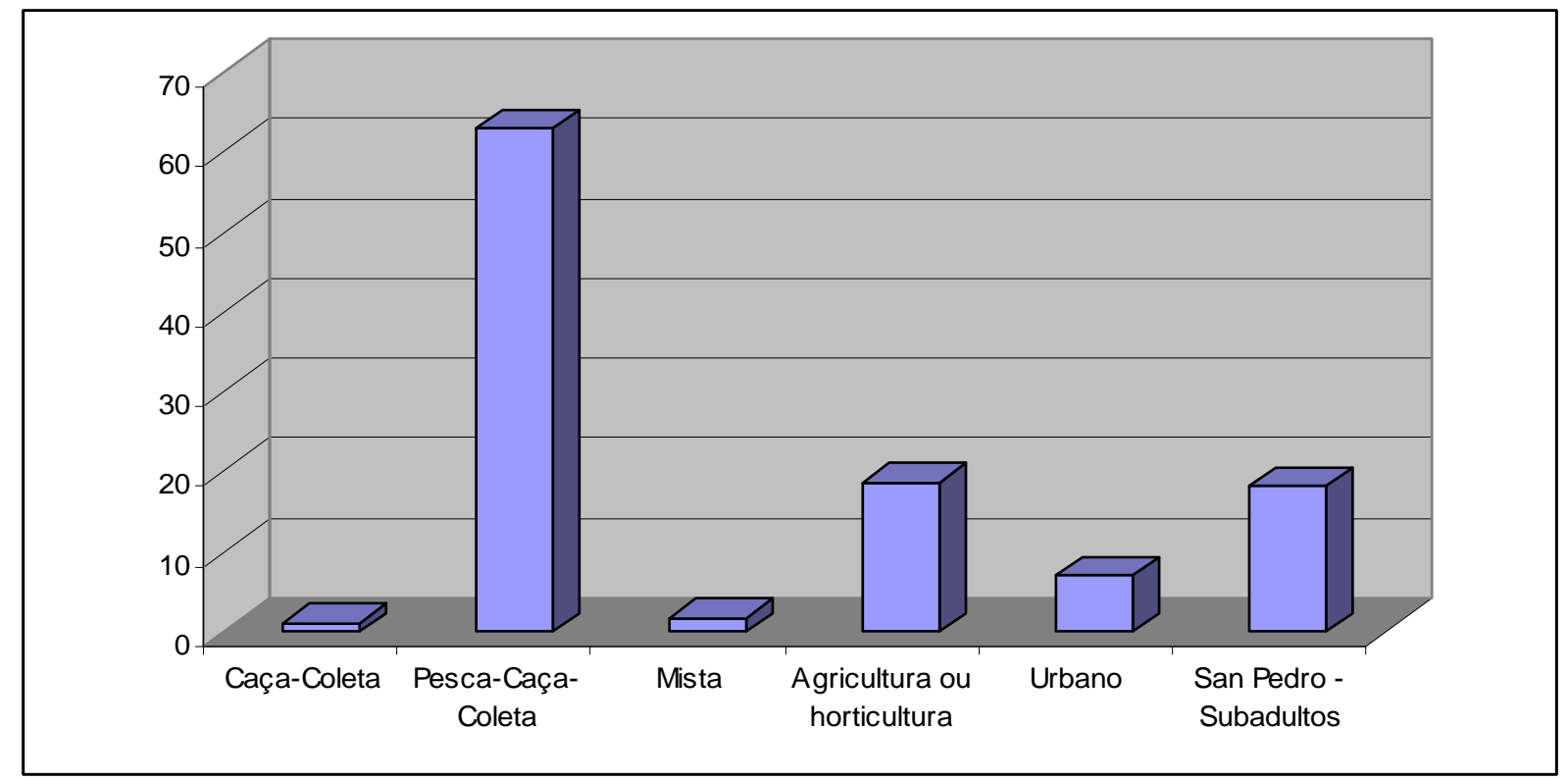

Figura 48 - Comparação entre a porcentagem de indivíduos afetados por hiperostose porótica dos subadultos em San Pedro de Atacama e as médias das diferentes estratégias de subsistência.

Uma parte da literatura sobre hiperostose porótica apresenta a distribuição do marcador por faixas etárias, o que permitiu uma comparação mais detalhada com os dados de San Pedro de Atacama. Quatro séries esqueletais foram utilizadas na comparação: Romano-Britânica, Núbia, Dickson Mounds e Eiden, e Pueblo Arroyo Hondo. Estas populações são agricultoras, à exceção de Dickson Mounds e Eiden, que indicam transição entre caça-coleta e agricultura (Tabela 95). Quando as faixas etárias de uma dessas populações não coincidiram com as adotadas neste estudo, os dados de San Pedro foram convertidos para permitir a comparação.

A população Romano-Britânica apresenta alta incidência de cribra orbitalia em comparação com San Pedro de Atacama (Figura 49). A diferença é significativa entre zero e quatro anos de idade, e entre os valores totais (zero a dezessete anos); o teste empregado foi o Qui-quadrado e o teste Exato de Fisher, comparando as frequências de indivíduos 
Tabela 95 - Estudos que apresentam, para cada faixa etária, dados de incidência de subadultos afetados por hiperostose porótica.

\begin{tabular}{cccc}
\hline Série esqueletal & Subsistência & Datação (BP)/ Período & Referência \\
\hline Dickson Mounds e Eiden & CC-Ag & $1100-510$ & Lallo et al. (1977) \\
Medieval Crhistian de Kulubnarti, Núbia & $\mathrm{Ag}$ & $1450-500$ & Mittler e van Gerven (1994) \\
Poundbury Camp, Romano Britânico & $\mathrm{Ag}$ & 1500 (Idade do Bronze) & Stuart-Macadam (1985) \\
Pueblo Arroyo Hondo, EUA & $\mathrm{Ag}$ & $700-630$ & Palkovich (1987) \\
\hline
\end{tabular}

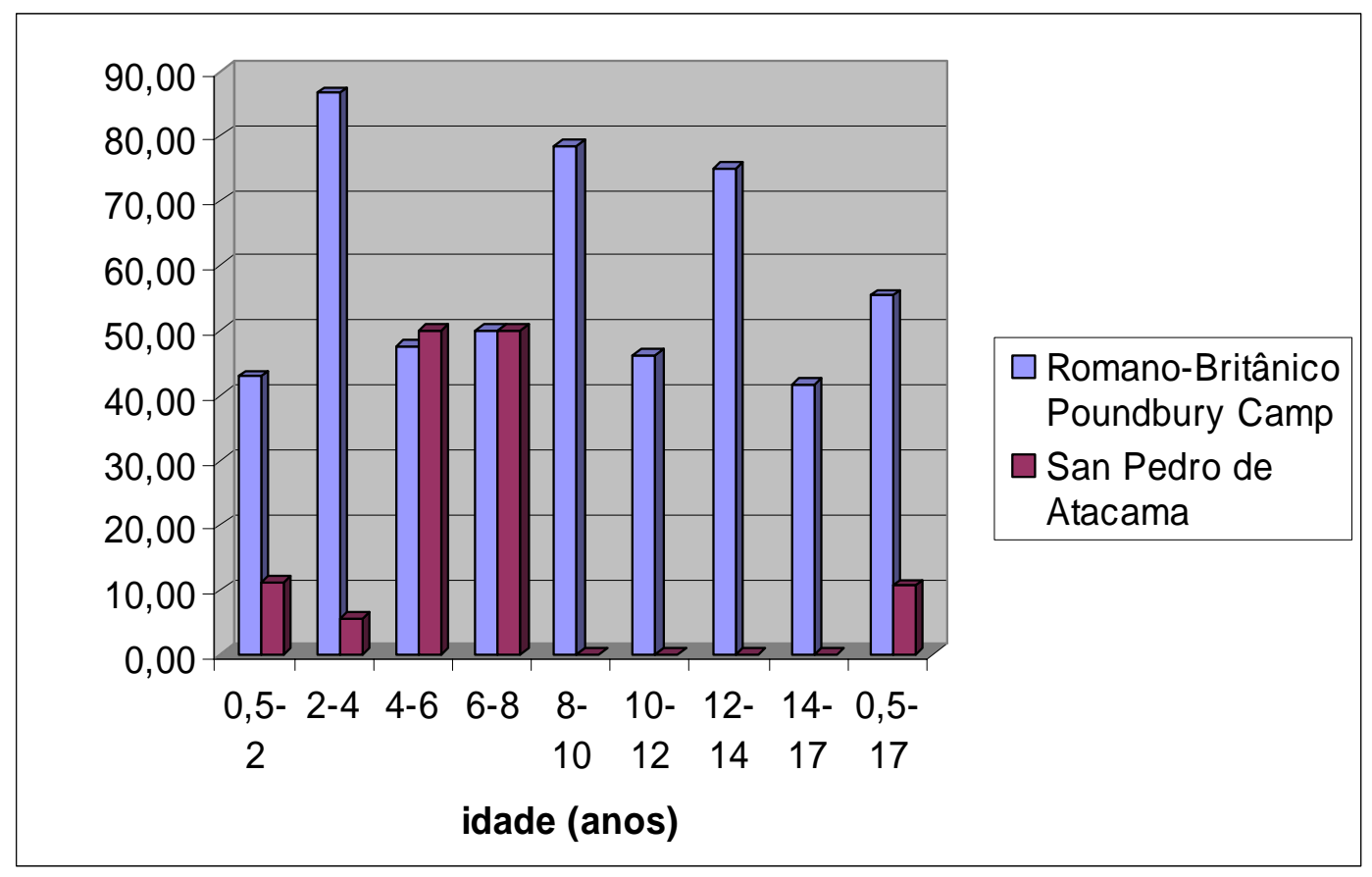

Figura 49 - Comparação da porcentagem de indivíduos afetados por cribra orbitalia para cada uma das faixas etárias. 
afetados entre as duas populações para cada faixa etária (Tabela 96). O mesmo tipo de análise foi empregado para as lesões na calota. Os resultados, no entanto, apresentaram uma diferença menos acentuada entre tais populações (Figura 50); a única diferença significativa foi na faixa etária de dois a quatro anos (Tabela 97). Essa única diferença deve ser vista com cautela, pois o restante das faixas etárias apresentou um tamanho amostral muito pequeno para permitir que os testes estatísticos detectassem diferenças significativas.

A população da Núbia apresenta, também, maior incidência de indivíduos afetados por cribra orbitalia em comparação com San Pedro de Atacama (Figura 51). Tal diferença é significativa nas faixas etárias de dois a três, de quatro a seis, de dez a doze anos e na população total (zero a vinte anos). Os testes aplicados foram o Qui-quadrado e o teste Exato de Fisher, comparando freqüências entre as duas populações para cada faixa etária (Tabela 98).

A população de Dickson Mounds e Eiden apresentou maior incidência de indivíduos afetados pela hiperostose porótica que a população atacamenha em todas as faixas etárias (Figura 52). Os resultados são significativos na faixa etária de dois a cinco anos e na população total (zero a quinze anos), utilizando os mesmos testes acima (Tabela 99).

Tabela 96 - Freqüência absoluta e porcentagem de indivíduos afetados pela cribra orbitalia; e valor de P dos testes Qui-quadrado e Exato de Fisher comparando as freqüências de indivíduos afetados entre as populações para cada faixa etária.

\begin{tabular}{|c|c|c|c|c|c|c|c|}
\hline \multicolumn{3}{|c|}{ Romano-Britânico Poundbury Camp } & \multicolumn{3}{|c|}{ San Pedro de Atacama } & \multirow[b]{2}{*}{ P (Qui-quadrado)** } & \multirow[b]{2}{*}{$\mathrm{P}$ (Fisher) $)^{\star \star}$} \\
\hline $\begin{array}{l}\text { Faixa } \\
\text { etária }\end{array}$ & $\begin{array}{l}\text { Freqüência } \\
\text { absoluta }\end{array}$ & Porcentagem & $\begin{array}{l}\text { Faixa } \\
\text { etária* }\end{array}$ & $\begin{array}{l}\text { Freqüência } \\
\text { absoluta }\end{array}$ & Porcentagem & & \\
\hline $0,5-2$ & $15 / 35$ & 42,86 & $0,5-2$ & $3 / 27$ & 11,11 & 0,0144 & 0,0101 \\
\hline $2-4$ & $13 / 15$ & 86,67 & $2-4$ & $1 / 18$ & 5,56 & $<0,0001$ & $<0,0001$ \\
\hline $4-6$ & $10 / 21$ & 47,62 & $4-6$ & $1 / 2$ & 50,00 & 0,9486 & 1,0000 \\
\hline $6-8$ & $5 / 10$ & 50,00 & $6-8$ & $1 / 2$ & 50,00 & 1,0000 & 1,5455 \\
\hline 8-10 & $11 / 14$ & 78,57 & $8-10$ & $0 / 1$ & 0,00 & 0,5850 & 0,2667 \\
\hline $10-12$ & $6 / 13$ & 46,15 & $10-12$ & $0 / 3$ & 0,00 & 0,4083 & 0,2500 \\
\hline $12-14$ & $6 / 8$ & 75,00 & $12-14$ & $0 / 2$ & 0,00 & 0,2586 & 0,1313 \\
\hline $14-17$ & $5 / 12$ & 41,67 & $14-17$ & $0 / 1$ & 0,00 & 0,4106 & 1,0000 \\
\hline $0,5-17$ & $71 / 128$ & 55,47 & $0,5-17$ & $6 / 56$ & 10,71 & $<0,0001$ & $<0,0001$ \\
\hline
\end{tabular}


Tabela 97 - Freqüência absoluta e porcentagem de indivíduos afetados pela hiperostose porótica na calota; e valor de P dos testes Qui-quadrado e Exato de Fisher comparando as freqüências de indivíduos afetados entre as populações para cada faixa etária.

\begin{tabular}{cccccccc}
\hline \multicolumn{2}{l}{ Romano-Britânico Poundbury Camp } & \multicolumn{7}{c}{ San Pedro de Atacama } \\
\hline $\begin{array}{c}\text { Faixa } \\
\text { etária }\end{array}$ & $\begin{array}{c}\text { Freqüência } \\
\text { absoluta }\end{array}$ & Porcentagem & $\begin{array}{c}\text { Faixa } \\
\text { etária* }\end{array}$ & $\begin{array}{c}\text { Freqüência } \\
\text { absoluta }\end{array}$ & Porcentagem & P (Qui-quadrado) & P (Fisher) \\
$0,5-2$ & $9 / 35$ & 25,71 & $0,5-2$ & $2 / 22$ & 9,09 & 0,2228 & 0,1740 \\
$2-4$ & $6 / 15$ & 40,00 & $2-4$ & $1 / 17$ & 5,88 & 0,0573 & $\mathbf{0 , 0 3 3 0}$ \\
$4-6$ & $5 / 21$ & 23,81 & $4-6$ & $0 / 2$ & 0,00 & 0,4354 & 1,0000 \\
$6-8$ & $0 / 10$ & 0,00 & $6-8$ & $0 / 2$ & 0,00 & - & - \\
$8-10$ & $2 / 14$ & 14,29 & $8-10$ & $1 / 2$ & 50,00 & 0,8087 & 0,3500 \\
$10-12$ & $0 / 13$ & 0,00 & $10-12$ & $0 / 3$ & 0,00 & 0,4083 & 0,2500 \\
$12-14$ & $0 / 8$ & 0,00 & $12-14$ & $0 / 2$ & 0,00 & 0,2586 & 0,1333 \\
$14-17$ & $0 / 12$ & 0,00 & $14-17$ & $1 / 1$ & 100,00 & 0,0984 & 0,0769 \\
$0,5-17$ & $22 / 128$ & 17,19 & $0,5-17$ & $5 / 51$ & 9,80 & 0,3103 & 0,2540 \\
\hline
\end{tabular}

* as idades dos esqueletos que se incluem em mais de uma faixa etária foram inseridas na mais jovem.

** valores em negrito são significantes.

Tabela 98 - Freqüência absoluta e porcentagem de indivíduos afetados pela cribra orbitalia; e valor de $\mathrm{P}$ dos testes Qui-quadrado e Exato de Fisher comparando as freqüências de indivíduos afetados entre as populações para cada faixa etária.

\begin{tabular}{|c|c|c|c|c|c|c|c|}
\hline \multicolumn{3}{|c|}{$\begin{array}{l}\text { Medieval Crhistian de Kulubnarti } \\
\text { (Núbia) }\end{array}$} & \multicolumn{3}{|c|}{ San Pedro de Atacama } & \multirow[b]{2}{*}{ P (Qui-quadrado)** } & \multirow[b]{2}{*}{$\mathrm{P}(\text { Fisher) })^{\star \star}$} \\
\hline $\begin{array}{l}\text { Faixa } \\
\text { etária }\end{array}$ & $\begin{array}{l}\text { Freqüência } \\
\text { absoluta }\end{array}$ & Porcentagem & $\begin{array}{l}\text { Faixa } \\
\text { etária }\end{array}$ & $\begin{array}{l}\text { Freqüência } \\
\text { absoluta }\end{array}$ & Porcentagem & & \\
\hline $0-1$ & $7 / 41$ & 17,07 & $0-1$ & $1 / 27$ & 3,70 & 0,1972 & 0,1331 \\
\hline $2-3$ & $17 / 34$ & 50,00 & $2-3$ & $3 / 18$ & 16,67 & 0,0403 & 0,0334 \\
\hline $4-6$ & $42 / 54$ & 77,78 & $4-6$ & $1 / 6$ & 16,67 & 0,0075 & 0,0056 \\
\hline $7-9$ & $14 / 19$ & 73,68 & $7-9$ & $1 / 2$ & 50,00 & 0,4807 & 0,5000 \\
\hline $10-12$ & $18 / 24$ & 75,00 & $10-12$ & $0 / 5$ & 0,00 & 0,0083 & 0,0039 \\
\hline $13-15$ & $8 / 16$ & 50,00 & $13-15$ & $0 / 2$ & 0,00 & 0,5572 & 0,4771 \\
\hline $16-20$ & $6 / 16$ & 37,50 & $16-20$ & $0 / 2$ & 0,00 & 0,7909 & 0,5294 \\
\hline $0-20$ & $112 / 204$ & 54,90 & $0-20$ & $6 / 62$ & 9,68 & $<0,0001$ & $<0,0001$ \\
\hline
\end{tabular}

* os esqueletos com idades intermediárias entre as faixas etárias foram inseridos nas mais jovens.

** valores em negrito são significantes. 
Tabela 99 - Freqüência absoluta e porcentagem de indivíduos afetados pela hiperostose porótica; e valor de P dos testes Qui-quadrado e Exato de Fisher comparando as freqüências de indivíduos afetados entre as populações para cada faixa etária.

\begin{tabular}{|c|c|c|c|c|c|c|c|}
\hline \multicolumn{3}{|c|}{ Dickson Mounds e Eiden } & \multicolumn{3}{|c|}{ San Pedro de Atacama } & \multirow[b]{2}{*}{ P (Qui-quadrado)* } & \multirow[b]{2}{*}{$\mathrm{P}$ (Fisher)* } \\
\hline $\begin{array}{l}\text { Faixa } \\
\text { etária }\end{array}$ & $\begin{array}{c}\text { Freqüência } \\
\text { absoluta }\end{array}$ & Porcentagem & $\begin{array}{l}\text { Faixa } \\
\text { etária }\end{array}$ & $\begin{array}{c}\text { Freqüência } \\
\text { absoluta }\end{array}$ & Porcentagem & & \\
\hline $0-0,9$ & $17 / 81$ & 20,99 & $0-0,9$ & $2 / 22$ & 9,09 & 0,3341 & 0,3514 \\
\hline $1-1,9$ & $14 / 48$ & 29,17 & $1-1,9$ & $0 / 6$ & 0,00 & 0,2970 & 0,3213 \\
\hline $2-4,9$ & $24 / 51$ & 47,06 & $2-4,9$ & $4 / 22$ & 18,18 & 0,0388 & 0,0344 \\
\hline $5-9,9$ & $35 / 56$ & 62,50 & $5-9,9$ & $2 / 4$ & 50,00 & 0,6194 & 0,6335 \\
\hline $10-14,9$ & $13 / 33$ & 39,39 & $10-14,9$ & $1 / 7$ & 14,29 & 0,4072 & 0,3870 \\
\hline $0-14,9$ & $103 / 269$ & 38,29 & $0-14,9$ & $9 / 61$ & 14,75 & 0,0008 & 0,0003 \\
\hline
\end{tabular}

* valores em negrito são significantes.

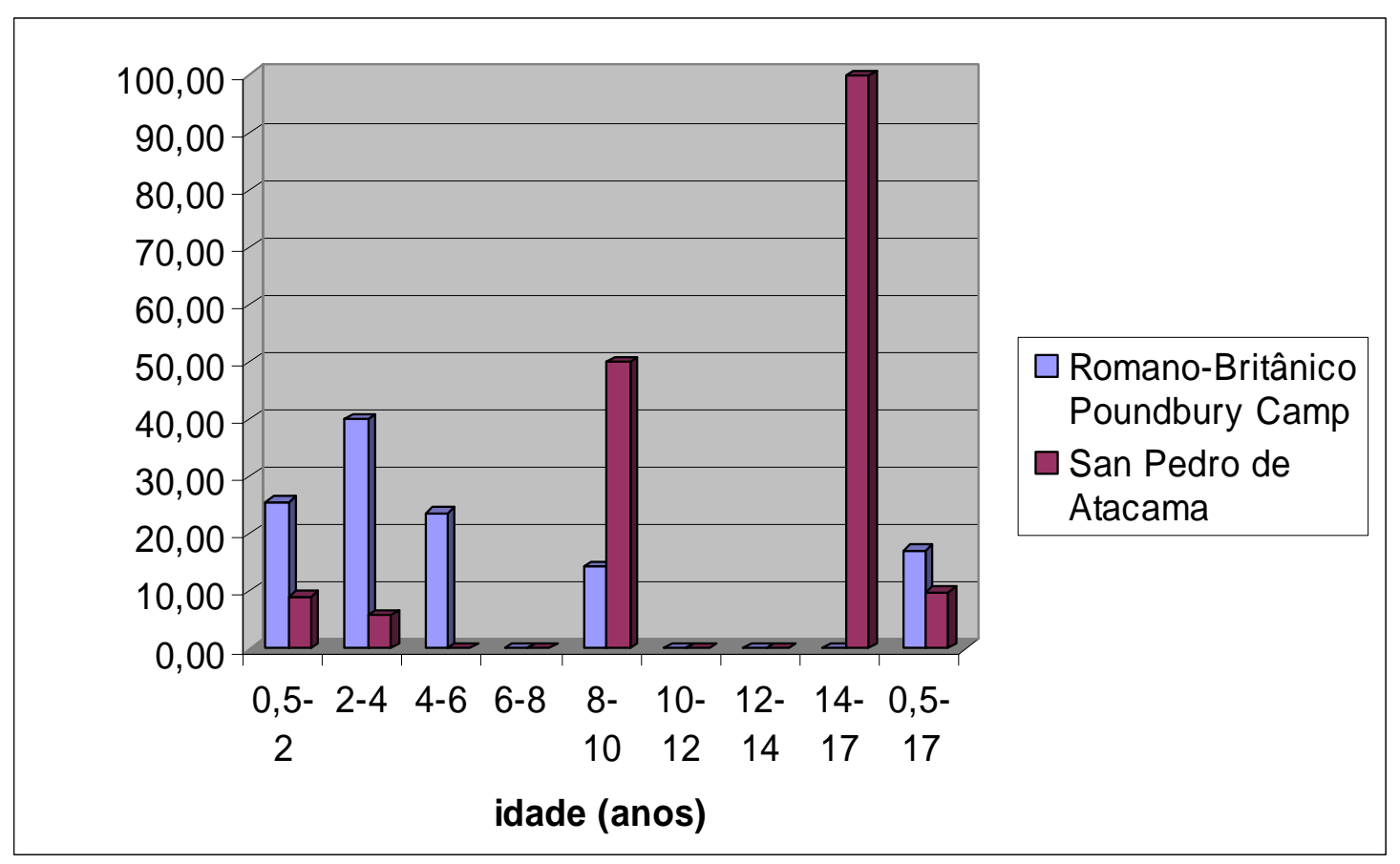

Figura 50 - Comparação da porcentagem de indivíduos afetados por hiperostose porótica na calota para cada uma das faixas etárias. 


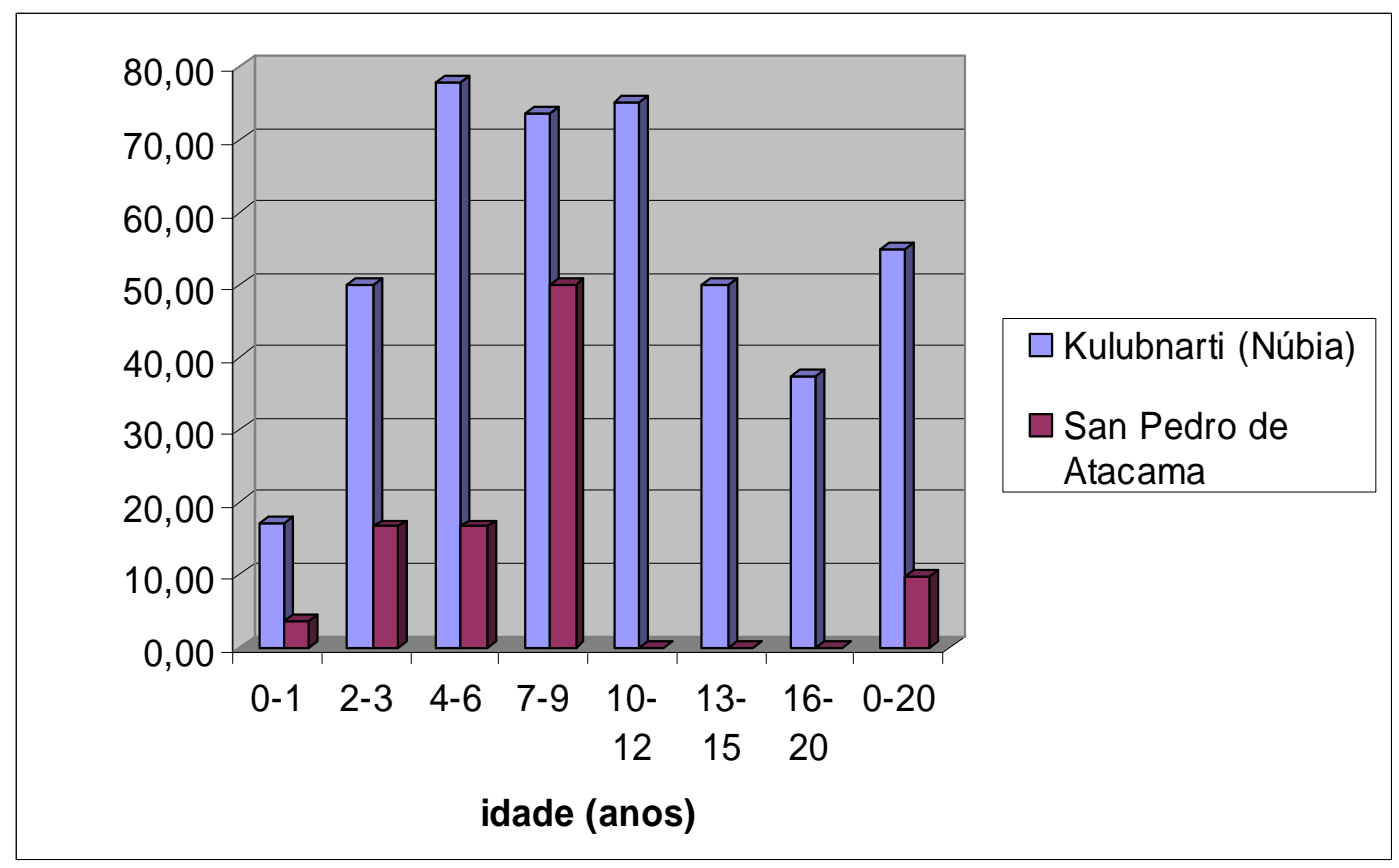

Figura 51 - Comparação da porcentagem de indivíduos afetados por cribra orbitalia para cada uma das faixas etárias.

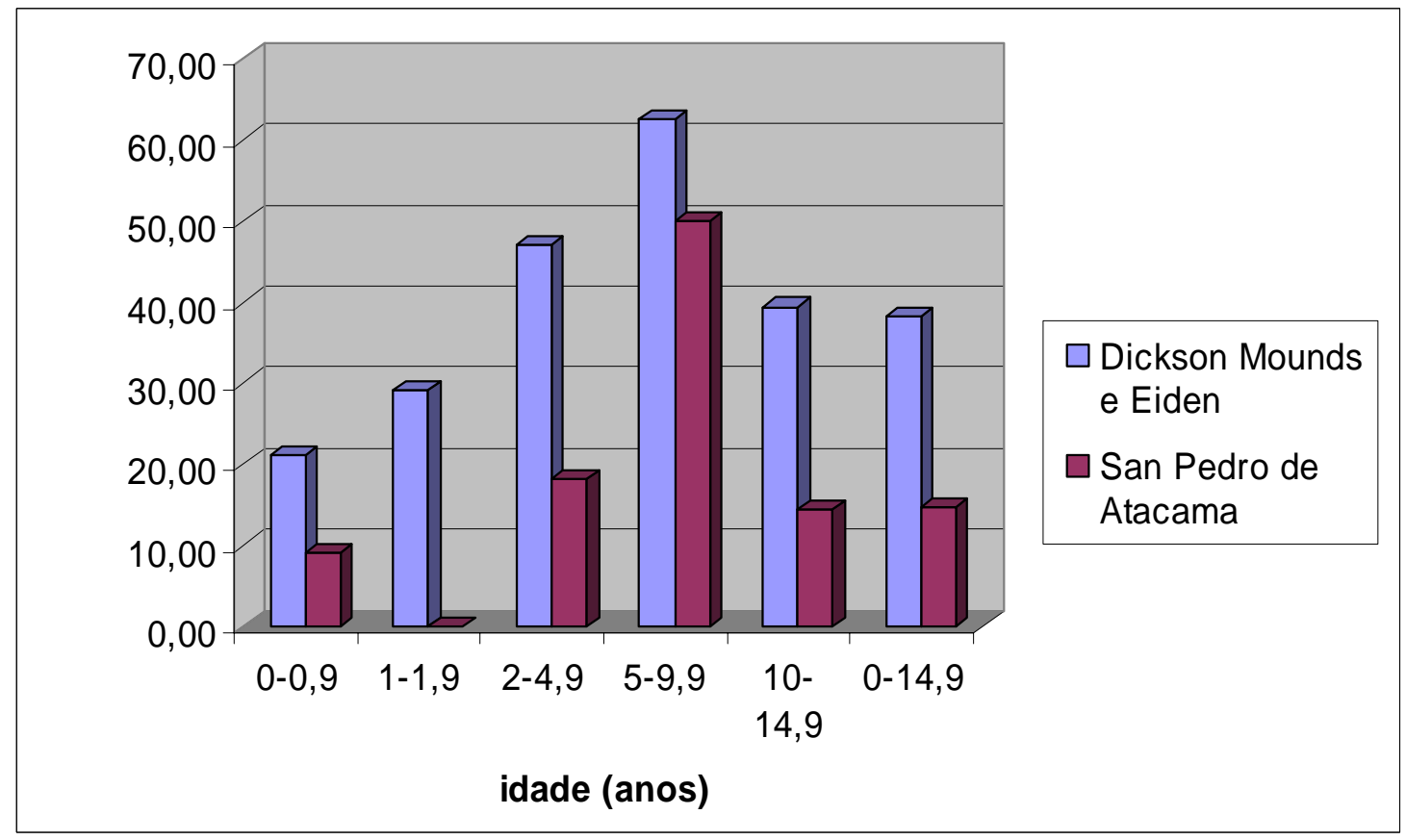

Figura 52 - Comparação da porcentagem de indivíduos afetados por hiperostose porótica para cada uma das faixas etárias. 
A população de Pueblo Arroyo Hondo apresentou maior incidência de indivíduos afetados por hiperostose porótica que San Pedro de Atacama entre zero e dez anos, apesar dessa diferença não ter sido estatisticamente significativa. A diferença entre as populações nos valores totais (0-9,9 anos) foi adquirida nos três primeiros anos de idade em favor de Pueblo Arroyo Honda; entre três e dez anos San Pedro apresentou maior incidência (Tabela 100 e Figura 53).

\subsection{6 - Infecções inespecíficas}

As infecções inespecíficas (total) nos esqueletos subadultos de San Pedro de Atacama apresentam uma incidência de 22,73\%. Os esqueletos entre zero e quatro anos apresentam baixo índice de afecção, com especial destaque para a faixa etária de um a dois anos (0\%). Entre quatro e dez anos a incidência sobe, voltando a cair entre dez e vinte anos (Tabela 101 e Figura 54). Quando as infecções (total) são analisadas separadamente em periostite e osteomielite, nota-se uma ligeira diferença entre elas. Periostite localizada apresenta uma alta incidência na faixa etária de quinze a vinte anos (Tabela 102 e Figura 55), enquanto periostite extensa apresenta o maior índice na faixa etária de cinco a dez anos (Tabela 103 e Figura 56). Já osteomielite localizada e extensa apresentam o maior índice de afecção entre quatro e cinco anos (Figura 57 e 58 e Tabela 104 e 105).

A comparação das incidências em San Pedro de Atacama com as populações mundiais foi realizada apenas para periostite localizada e para tíbias afetadas (Tabelas 106 e 107). Periostite localizada em San Pedro corresponde à periostite leve na literatura, em oposição a infecções sistêmicas. A segunda comparação, a das tíbias, foi feita incluindo periostite e osteomielite. É importante lembrar que os dados das populações mundiais são principalmente de esqueletos adultos.

O índice de afecção de periostite localizada nos esqueletos subadultos de San Pedro de Atacama é de 10,23\%. Este valor está muito próximo da média das populações que viveram em meios urbanizados (9,13\%); os agricultores apresentam afecção mais alta (18,62\%), porém o desvio padrão é também bastante alto $(16,09)$. Os caçadores-coletores não apresentaram infecções, com a ressalva que os mesmos estão representados por apenas uma população (Santa Elena) (Tabela 108 e Figura 59). O teste de Mann-Whitney 
Tabela 100 - Freqüência absoluta e porcentagem de indivíduos afetados pela hiperostose porótica; e valor de P dos testes Quiquadrado e Exato de Fisher comparando as freqüências de indivíduos afetados entre as populações para cada faixa etária.

\begin{tabular}{cccccccc}
\hline \multicolumn{7}{c}{ Pueblo - Arroyo Hondo } & \multicolumn{3}{c}{ San Pedro de Atacama } \\
\hline $\begin{array}{c}\text { Faixa } \\
\text { etária }\end{array}$ & $\begin{array}{c}\text { Freqüência } \\
\text { absoluta }\end{array}$ & Porcentagem & $\begin{array}{r}\text { Faixa } \\
\text { etária }\end{array}$ & $\begin{array}{c}\text { Freqüência } \\
\text { absoluta }\end{array}$ & Porcentagem & P (Qui-quadrado) & P (Fisher) \\
$0-0,5$ & $5 / 19$ & 26,32 & $0-0,5$ & $1 / 17$ & 5,88 & 0,2323 & 0,1821 \\
$0,5-1$ & $3 / 10$ & 30,00 & $0,5-1$ & $1 / 8$ & 12,50 & 0,7513 & 0,5852 \\
$1-3$ & $4 / 15$ & 26,67 & $1-3$ & $3 / 18$ & 16,67 & 0,7855 & 0,6741 \\
$3-5$ & $0 / 5$ & 0,00 & $3-5$ & $2 / 9$ & 22,22 & 0,8385 & 1,0000 \\
$5-9,9$ & $0 / 5$ & 0,00 & $5-9,9$ & $1 / 2$ & 50,00 & 0,7825 & 0,3750 \\
$0-9,9$ & $12 / 54$ & 22,22 & $0-9,9$ & $8 / 54$ & 14,81 & 0,4574 & 0,4581 \\
\hline
\end{tabular}

* as idades dos esqueletos que se incluem em mais de uma faixa etária foram inseridas na mais jovem.

Tabela 101 - Freqüência absoluta e porcentagem de indivíduos em San Pedro de Atacama afetados por infecções (total).

\begin{tabular}{|c|c|c|c|c|c|c|c|c|c|c|}
\hline & Sol & 3 pre & Solc & Tiw & & & & $r-6$ & & \\
\hline Faixa etári & $\begin{array}{l}\text { reqüênc } \\
\text { absoluta }\end{array}$ & rcentas & $\begin{array}{l}\text { reqüênci } \\
\text { absoluta }\end{array}$ & rcenta & $\begin{array}{l}\text { reqüênc } \\
\text { absoluta }\end{array}$ & rcenta & $\begin{array}{l}\text { reqüênci } \\
\text { absoluta }\end{array}$ & orcenta & $\begin{array}{l}\text { reqüên } \\
\text { absolut }\end{array}$ & rcent \\
\hline $0-0,9$ & $1 / 12$ & 8,33 & $1 / 5$ & 20,00 & $0 / 8$ & 0,00 & $2 / 5$ & 40,00 & $4 / 30$ & 13,33 \\
\hline $1-1,9$ & $0 / 5$ & 0,00 & $0 / 2$ & 0,00 & $0 / 1$ & 0,00 & - & - & $0 / 8$ & 0,00 \\
\hline $2-2,9$ & $1 / 6$ & 16,67 & $1 / 3$ & 33,33 & $1 / 3$ & 33,33 & - & - & $3 / 12$ & 25,00 \\
\hline $3-3,9$ & $1 / 3$ & 33,33 & $1 / 2$ & 50,00 & $0 / 3$ & 0,00 & $1 / 3$ & 33,33 & $3 / 11$ & 27,27 \\
\hline $4-4,9$ & $1 / 1$ & 100,00 & $1 / 2$ & 50,00 & - & - & $1 / 2$ & 50,00 & $3 / 5$ & 60,00 \\
\hline $5-9,9$ & $1 / 3$ & 33,33 & $0 / 1$ & 0,00 & $1 / 1$ & 100,00 & $1 / 1$ & 100,00 & $3 / 6$ & 50,00 \\
\hline $10-14,9$ & $2 / 5$ & 40,00 & $0 / 1$ & 0,00 & $0 / 1$ & 0,00 & $0 / 2$ & 0,00 & $2 / 9$ & 22,22 \\
\hline $15-19,9$ & $1 / 4$ & 25,00 & $1 / 2$ & 50,00 & $0 / 1$ & 0,00 & - & - & $2 / 7$ & 28,57 \\
\hline $0-19,9$ & $8 / 39$ & 20,51 & $5 / 18$ & 27,78 & $2 / 18$ & 11,11 & $5 / 13$ & 38,46 & $20 / 88$ & 22,73 \\
\hline
\end{tabular}


Tabela 102 - Freqüência absoluta e porcentagem de indivíduos em San Pedro de Atacama afetados por periostite localizada.

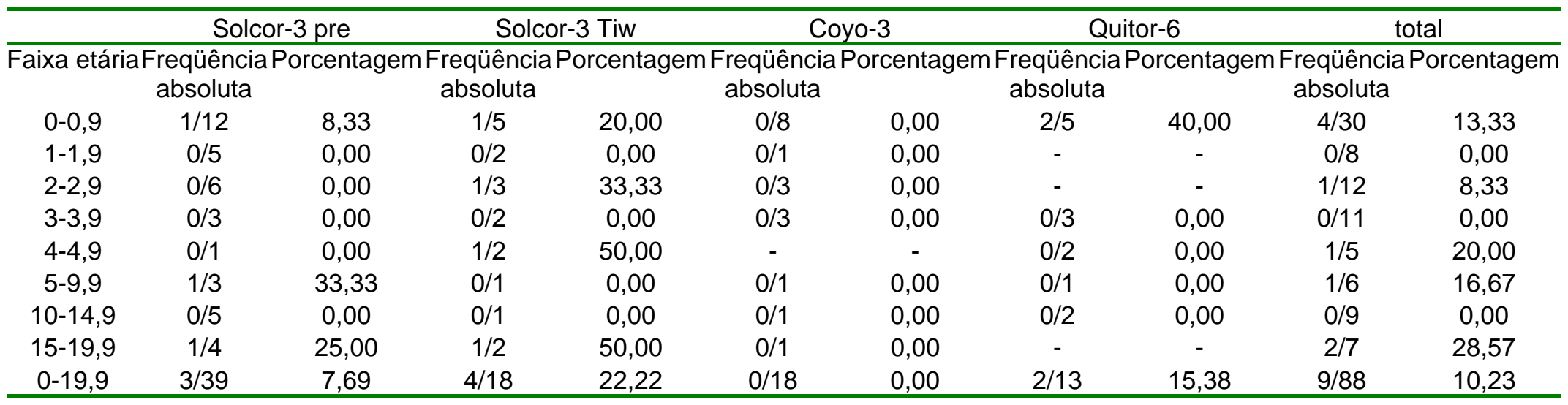

Tabela 103 - Freqüência absoluta e porcentagem de indivíduos em San Pedro de Atacama afetados por periostite extensa.

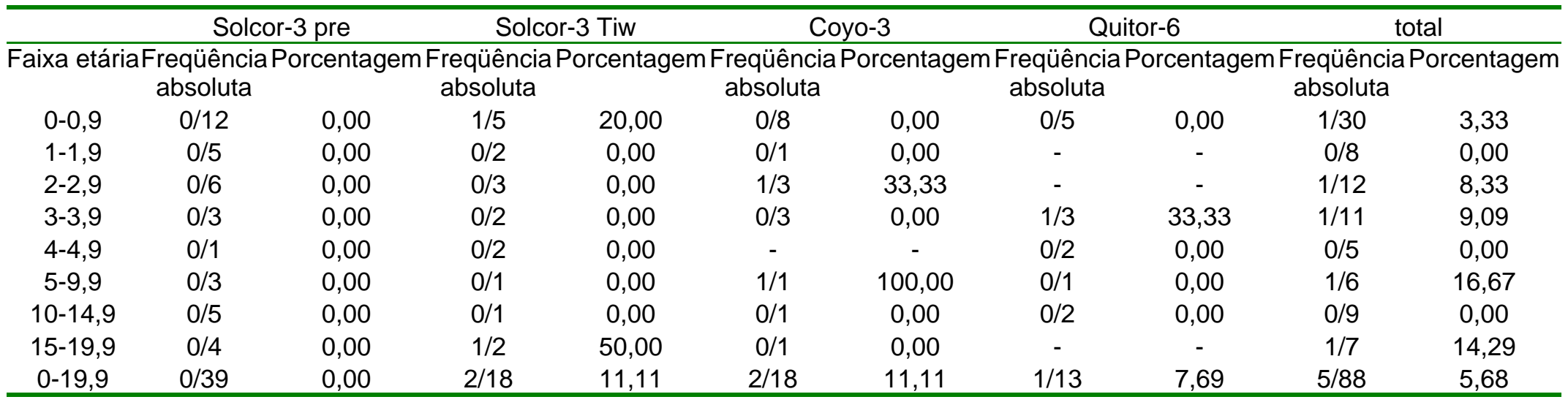


Tabela 104 - Freqüência absoluta e porcentagem de indivíduos em San Pedro de Atacama afetados por osteomielite localizada.

\begin{tabular}{|c|c|c|c|c|c|c|c|c|c|c|}
\hline & \multicolumn{2}{|c|}{ Solcor-3 pre } & \multicolumn{2}{|c|}{ Solcor-3 Tiw } & \multicolumn{2}{|c|}{ Coyo-3 } & \multicolumn{2}{|c|}{ Quitor-6 } & \multicolumn{2}{|c|}{ total } \\
\hline Faixa etári & $\begin{array}{l}\text { reqüência } \\
\text { absoluta }\end{array}$ & rrcentage & $\begin{array}{l}\text { reqüênci } \\
\text { absoluta }\end{array}$ & rcentag & $\begin{array}{l}\text { Ereqüênci } \\
\text { absoluta }\end{array}$ & cent & $\begin{array}{l}\text { reqüênci } \\
\text { absoluta }\end{array}$ & orcenta & $\begin{array}{l}\text { reqüênc } \\
\text { absoluta }\end{array}$ & rcentagen \\
\hline $0-0,9$ & $0 / 12$ & 0,00 & $1 / 5$ & 20,00 & $0 / 8$ & 0,00 & $0 / 5$ & 0,00 & $1 / 30$ & 3,33 \\
\hline $1-1,9$ & $0 / 5$ & 0,00 & $0 / 2$ & 0,00 & $0 / 1$ & 0,00 & - & - & $0 / 8$ & 0,00 \\
\hline $2-2,9$ & $0 / 6$ & 0,00 & $0 / 3$ & 0,00 & $0 / 3$ & 0,00 & - & - & $0 / 12$ & 0,00 \\
\hline $3-3,9$ & $1 / 3$ & 33,33 & $1 / 2$ & 50,00 & $0 / 3$ & 0,00 & $1 / 3$ & 33,33 & $3 / 11$ & 27,27 \\
\hline $4-4,9$ & $1 / 1$ & 100,00 & $0 / 2$ & 0,00 & - & - & $1 / 2$ & 50,00 & $2 / 5$ & 40,00 \\
\hline $5-9,9$ & $0 / 3$ & 0,00 & $0 / 1$ & 0,00 & $0 / 1$ & 0,00 & $1 / 1$ & 100,00 & $1 / 6$ & 16,67 \\
\hline $10-14,9$ & $2 / 5$ & 40,00 & $0 / 1$ & 0,00 & $0 / 1$ & 0,00 & $0 / 2$ & 0,00 & $2 / 9$ & 22,22 \\
\hline $15-19,9$ & $0 / 4$ & 0,00 & $1 / 2$ & 50,00 & $0 / 1$ & 0,00 & - & - & $1 / 7$ & 14,29 \\
\hline $0-19,9$ & $4 / 39$ & 10,26 & $3 / 18$ & 16,67 & $0 / 18$ & 0,00 & $3 / 13$ & 23,08 & $10 / 88$ & 11,36 \\
\hline
\end{tabular}

Tabela 105 - Freqüência absoluta e porcentagem de indivíduos em San Pedro de Atacama afetados por osteomielite extensa.

\begin{tabular}{|c|c|c|c|c|c|c|c|c|c|c|}
\hline \multirow{2}{*}{ Faixa etária } & \multicolumn{2}{|c|}{ Solcor-3 pre } & \multicolumn{2}{|c|}{ Solcor-3 Tiw } & \multicolumn{2}{|c|}{ Coyo-3 } & \multicolumn{2}{|c|}{ Quitor-6 } & \multicolumn{2}{|r|}{ total } \\
\hline & $\begin{array}{c}\text { a Freqüência } \\
\text { absoluta }\end{array}$ & Porcentage & $\begin{array}{c}\text { Freqüência } \\
\text { absoluta }\end{array}$ & Porcentagem & $\begin{array}{c}\text { Freqüência } \\
\text { absoluta }\end{array}$ & Porcentagem & $\begin{array}{c}\text { Freqüência } \\
\text { absoluta }\end{array}$ & Porcentagem & $\begin{array}{l}\text { Freqüência } \\
\text { absoluta }\end{array}$ & Porcentagem \\
\hline $0-0,9$ & $0 / 12$ & 0,00 & $1 / 5$ & 20,00 & $0 / 8$ & 0,00 & $0 / 5$ & 0,00 & $1 / 30$ & 3,33 \\
\hline $1-1,9$ & $0 / 5$ & 0,00 & $0 / 2$ & 0,00 & $0 / 1$ & 0,00 & - & - & $0 / 8$ & 0,00 \\
\hline $2-2,9$ & $1 / 6$ & 16,67 & $0 / 3$ & 0,00 & $0 / 3$ & 0,00 & - & - & $1 / 12$ & 8,33 \\
\hline $3-3,9$ & $0 / 3$ & 0,00 & $0 / 2$ & 0,00 & $0 / 3$ & 0,00 & $0 / 3$ & 0,00 & 0/11 & 0,00 \\
\hline $4-4,9$ & $1 / 1$ & 100,00 & $0 / 2$ & 0,00 & - & - & $0 / 2$ & 0,00 & $1 / 5$ & 20,00 \\
\hline $5-9,9$ & $0 / 3$ & 0,00 & $0 / 1$ & 0,00 & $0 / 1$ & 0,00 & $0 / 1$ & 0,00 & $0 / 6$ & 0,00 \\
\hline $10-14,9$ & $1 / 5$ & 20,00 & $0 / 1$ & 0,00 & $0 / 1$ & 0,00 & $0 / 2$ & 0,00 & $1 / 9$ & 11,11 \\
\hline $15-19,9$ & $0 / 4$ & 0,00 & $0 / 2$ & 0,00 & $0 / 1$ & 0,00 & - & - & $0 / 7$ & 0,00 \\
\hline $0-19,9$ & $3 / 39$ & 7,69 & $1 / 18$ & 5,56 & $0 / 18$ & 0,00 & $0 / 13$ & 0,00 & $4 / 88$ & 4,55 \\
\hline
\end{tabular}


Tabela 106 - Levantamento bibliográfico dos estudos que apresentam dados para infecções.

\begin{tabular}{cccc}
\hline Série esqueletal & Subsistência* & Datação & Autor \\
\hline Equestrian nomads, EUA & $\mathrm{CC}$ & & Johansson e Owsley (2002) \\
Pré-agricultores pré-contato, Georgia, EUA & $\mathrm{CC}$ & $3050-800$ & Larsen et al. (2002) \\
Santa Elena, Equador & $\mathrm{CC}$ & $8250-6600$ & Ubelaker e Newson (2002) \\
Pawnee, EUA & $\mathrm{Mista}$ & $200-130$ & Johansson e Owsley (2002) \\
Arikara, EUA & $\mathrm{Ag}$ & & Johansson e Owsley (2002) \\
Copan rural, Maia & $\mathrm{Ag}$ & $\sim 1150-950$ & Storey et al. (2002) \\
Copan urban & $\mathrm{Ag}$ & $-1150-950$ & Storey et al. (2002) \\
Grupo agricultor pré-contato & $\mathrm{Ag}$ & $800-400$ & Larsen et al. (2002) \\
Grupo de contato anterior, Georgia, EUA & $\mathrm{Ag}$ & $400-270$ & Larsen et al. (2002) \\
Grupo de contato posterior, Georgia, EUA & $\mathrm{Ag}$ & $264-248$ & Larsen et al. (2002) \\
Highland pré-histórico, Equador & $\mathrm{Ag}$ & $2950-1500$ & Ubelaker e Newson (2002) \\
Indígenas históricos, EUA & $\mathrm{Ag}$ & $450-300$ & Ubelaker e Newson (2002) \\
Jaina, Maia & $\mathrm{Ag}$ & $1350-950$ & Storey et al. (2002) \\
North Coast, EUA & $\mathrm{Ag}$ & $2550-1550$ & Ubelaker e Newson (2002) \\
Nova Raca Croácia & $\mathrm{Ag}$ & $650-150$ (Medieval tardio) & Slaus (2000) \\
Omaha, EUA & $\mathrm{Ho}$ & & Johansson e Owsley (2002) \\
Real Alto & $\mathrm{Ag}$ & $5350-3450$ & Ubelaker e Newson (2002) \\
Série de sítios com agricultura intensiva & $\mathrm{Ag}$ & $2450-550$ & Hodges (1987) \\
Série de sítios com agricultura não intensiva & $\mathrm{Ho}$ & $3350-2450$ & Hodges (1987) \\
South Coast & $\mathrm{Ag}$ & $2850-220$ & Ubelaker e Newson (2002) \\
Xcaret, Maia & $\mathrm{Ag}$ & Pós-Clássico & Storey et al. (2002) \\
Escravos & Esc & Século XIX & Rathbun (1987) \\
Europeus 1 & Urb & $410-92$ & Ubelaker e Newson (2002) \\
Europeus 2 & Urb & $280-92$ & Ubelaker e Newson (2002) \\
Europeus 3 & Urb & $180-10$ & Ubelaker e Newson (2002) \\
Negros de Cedar Groove, Arkansas, EUA & Urb & $50-35$ & Davison et al. (2002) \\
Negros de Freedmans, EUA & Urb & $81-43$ & Davison et al. (2002) \\
\hline & & &
\end{tabular}

* CC=Caçador-Coletor; Ho=Horticultor; Ag=Agricultor; Esc=Escravos; Urb=Urbanizados. 
Tabela 107 - Incidência de infecções em diferentes populações mundiais.

\begin{tabular}{|c|c|c|c|c|c|}
\hline Série esqueletal & Subsistência* & Periostite - Leve & $\%$ & Tibia & $\%$ \\
\hline Equestrian nomads, EUA & $\mathrm{CC}$ & & & $15 / 33$ & 45,50 \\
\hline Pré-agricultores pré-contato, Georgia, EUA & $\mathrm{CC}$ & & & $12 / 126$ & 9,50 \\
\hline Santa Elena & $\mathrm{CC}$ & $0 / 75$ & 0,00 & $1 / 28$ & 3,40 \\
\hline Pawnee, EUA & Mista & & & $6 / 42$ & 26,80 \\
\hline Arikara, EUA & $\mathrm{Ag}$ & & & $9 / 59$ & 15,30 \\
\hline Copan rural, Maia & $\mathrm{Ag}$ & $16 / 45$ & 35,56 & & \\
\hline Copan urban & $\mathrm{Ag}$ & $101 / 239$ & 42,30 & & \\
\hline Grupo agricultor pré-contato & $\mathrm{Ag}$ & & & $66 / 331$ & 19,80 \\
\hline Grupo de contato anterior, Georgia, EUA & $\mathrm{Ag}$ & & & $4 / 26$ & 15,40 \\
\hline Grupo de contato posterior, Georgia, EUA & $\mathrm{Ag}$ & & & $57 / 96$ & 59,30 \\
\hline Highland pré-histórico, Equador & $\mathrm{Ag}$ & $5 / 164$ & 3,00 & $8 / 81$ & 9,90 \\
\hline Indígenas históricos, EUA & $\mathrm{Ag}$ & $1 / 39$ & 2,60 & $0 / 6$ & 0,00 \\
\hline Jaina, Maia & $\mathrm{Ag}$ & $27 / 102$ & 26,47 & & \\
\hline North Coast, EUA & $\mathrm{Ag}$ & $4 / 47$ & 8,50 & $8 / 23$ & 34,80 \\
\hline Nova Raca Croácia & $\mathrm{Ag}$ & $33 / 104$ & 31,70 & & \\
\hline Omaha, EUA & $\mathrm{Ho}$ & & & $4 / 40$ & 10,00 \\
\hline Real Alto & $\mathrm{Ag}$ & $0 / 51$ & 0,00 & $2 / 34$ & 5,90 \\
\hline Série de sítios com agricultura intensiva & $\mathrm{Ag}$ & & & $62 / 102$ & 60,80 \\
\hline Série de sítios com agricultura não intensiva & Ho & & & $29 / 48$ & 60,40 \\
\hline South Coast & $\mathrm{Ag}$ & 9/155 & 5,80 & $6 / 73$ & 8,20 \\
\hline Xcaret, Maia & $\mathrm{Ag}$ & $10 / 33$ & 30,30 & & \\
\hline Escravos & Esc & $23 / 33$ & 70,00 & & \\
\hline Europeus 1 & Urb & $17 / 104$ & 16,30 & $12 / 34$ & 35,30 \\
\hline Europeus 2 & Urb & $0 / 35$ & 0,00 & $0 / 11$ & 0,00 \\
\hline Europeus 3 & Urb & $6 / 54$ & 11,10 & $5 / 19$ & 26,30 \\
\hline Negros de Cedar Groove, Arkansas, EUA & Urb & & & $43 / 77$ & 55,80 \\
\hline Negros de Freedmans, EUA & Urb & & & $332 / 609$ & 54,50 \\
\hline
\end{tabular}

* CC=Caçador-Coletor; Ho=Horticultor; Ag=Agricultor; Esc=Escravos; Urb=Urbanizados. 
Tabela 108 - Estatísticas descritivas de infecções nas diferentes estratégias de subsistência, comparadas com os dados dos subadultos de San Pedro de Atacama.

\begin{tabular}{|c|c|c|c|c|}
\hline & & Periostite - Leve & & Tíbia \\
\hline \multirow[t]{5}{*}{ Caça-Coleta } & Média & 0,00 & Média & 19,47 \\
\hline & Desv Pad & - & Desv Pad & 22,75 \\
\hline & Max & 0,00 & Max & 45,50 \\
\hline & Mínimo & 0,00 & Mínimo & 3,40 \\
\hline & $\mathrm{N}$ & 1 & $\mathrm{~N}$ & 3 \\
\hline \multirow[t]{5}{*}{ Mista } & Média & - & Média & 26,80 \\
\hline & Desv Pad & - & Desv Pad & - \\
\hline & $\operatorname{Max}$ & - & $\operatorname{Max}$ & 26,80 \\
\hline & Mínimo & - & Mínimo & 26,80 \\
\hline & $\mathrm{N}$ & - & $\mathrm{N}$ & 1 \\
\hline \multirow[t]{5}{*}{ Agricultura ou Horticultura } & Média & 18,62 & Média & 24,98 \\
\hline & Desv Pad & 16,09 & Desv Pad & 22,85 \\
\hline & $\operatorname{Max}$ & 42,30 & Max & 60,80 \\
\hline & Mínimo & 0,00 & Mínimo & 0,00 \\
\hline & $\mathrm{N}$ & 10 & $\mathrm{~N}$ & 12 \\
\hline \multirow[t]{5}{*}{ Escravos } & Média & 70,00 & Média & - \\
\hline & Desv Pad & - & Desv Pad & - \\
\hline & Max & 70,00 & Max & - \\
\hline & Mínimo & 70,00 & Mínimo & - \\
\hline & $\mathrm{N}$ & 1 & $\mathrm{~N}$ & - \\
\hline \multirow[t]{5}{*}{ Urbano } & Média & 9,13 & Média & 34,38 \\
\hline & Desv Pad & 8,33 & Desv Pad & 22,98 \\
\hline & Max & 16,30 & Max & 55,80 \\
\hline & Mínimo & 0,00 & Mínimo & 0,00 \\
\hline & $\mathrm{N}$ & 3 & $\mathrm{~N}$ & 5 \\
\hline San Pedro - Subadultos & & 9/88 (10,23\%) & & $4 / 71(5,63 \%)$ \\
\hline
\end{tabular}




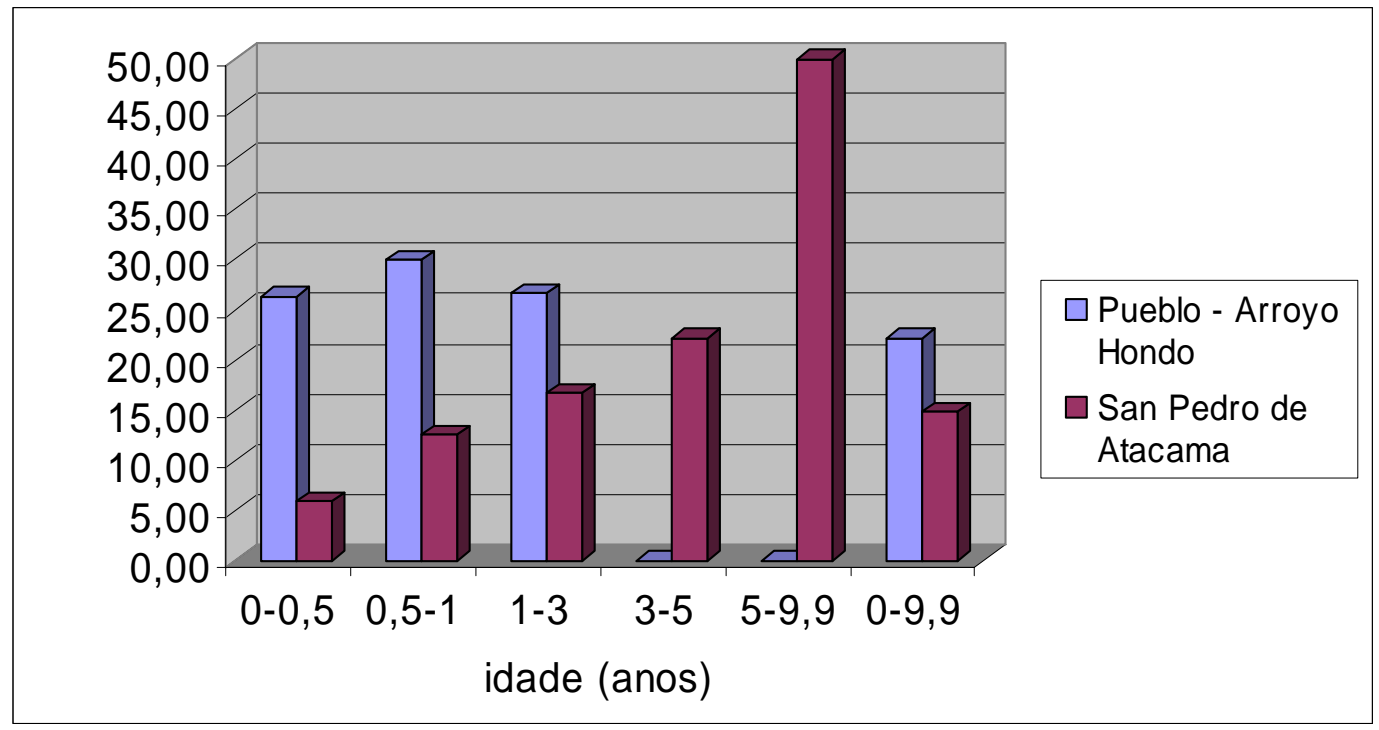

Figura 53 - Comparação da porcentagem de indivíduos afetados por hiperostose porótica para cada uma das faixas etárias.

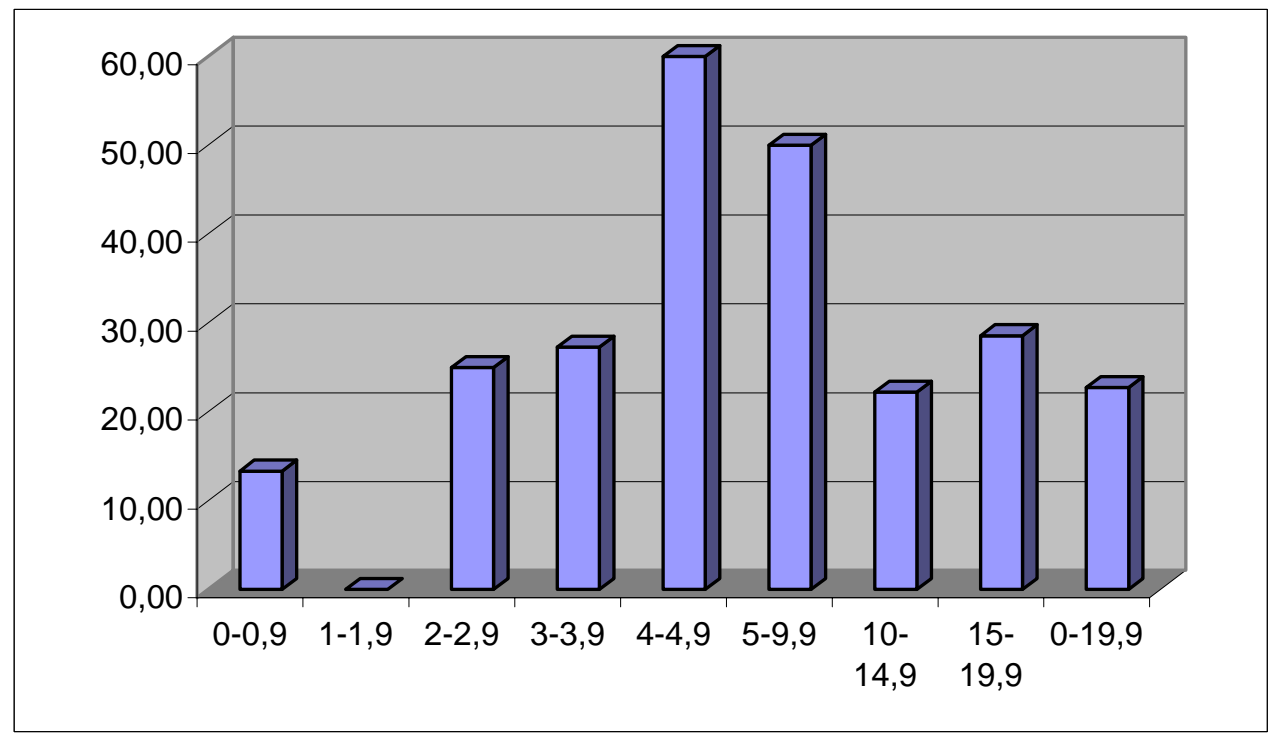

Figura 54 - Distribuição por faixa etária da porcentagem de indivíduos afetados por infecções (total) em San Pedro de Atacama. 


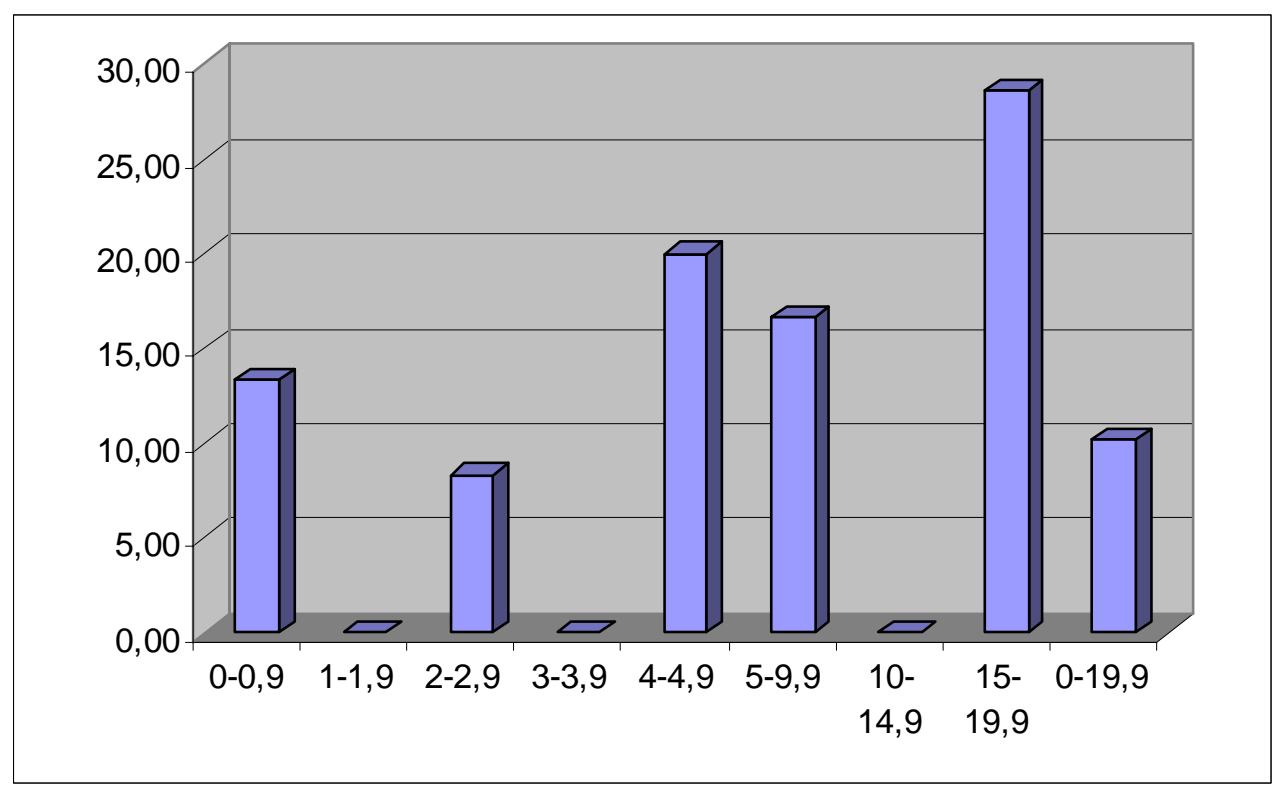

Figura 55 - Distribuição por faixa etária da porcentagem de indivíduos afetados por periostite localizada em San Pedro de Atacama.

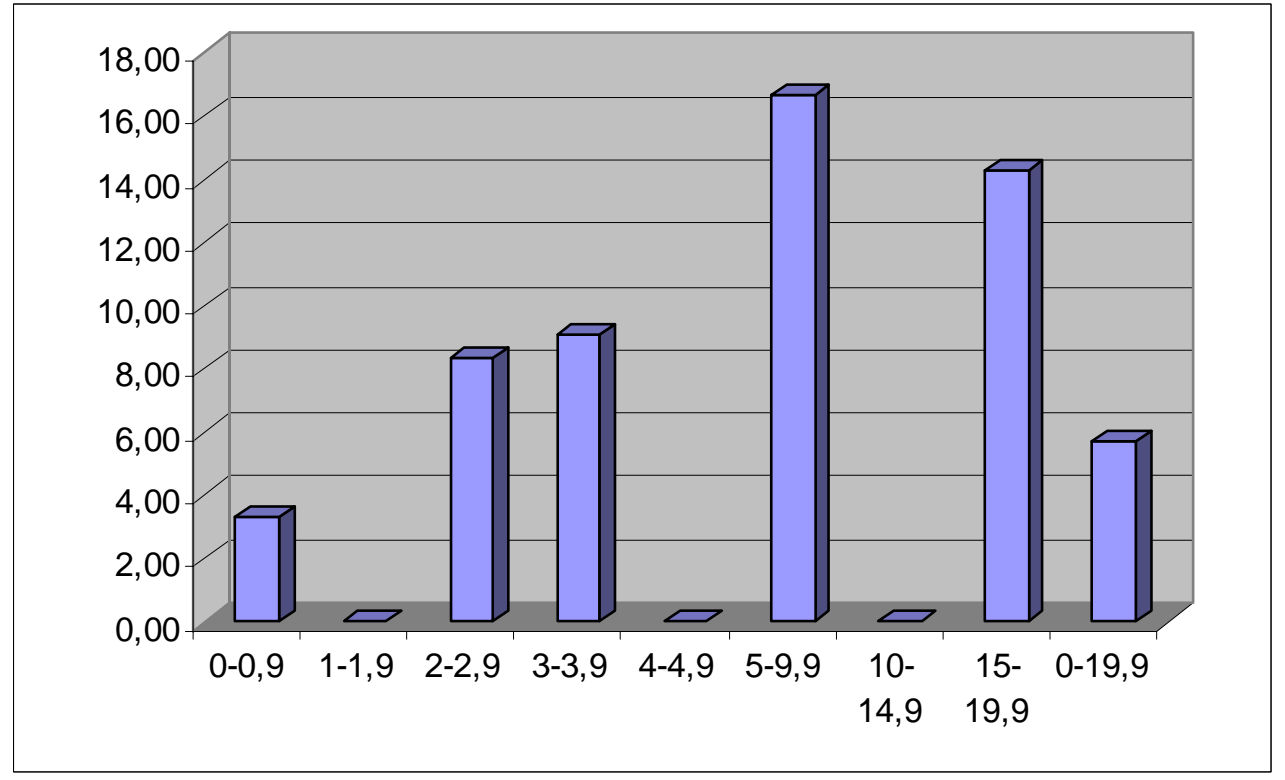

Figura 56 - Distribuição por faixa etária da porcentagem de indivíduos afetados por periostite extensa em San Pedro de Atacama. 


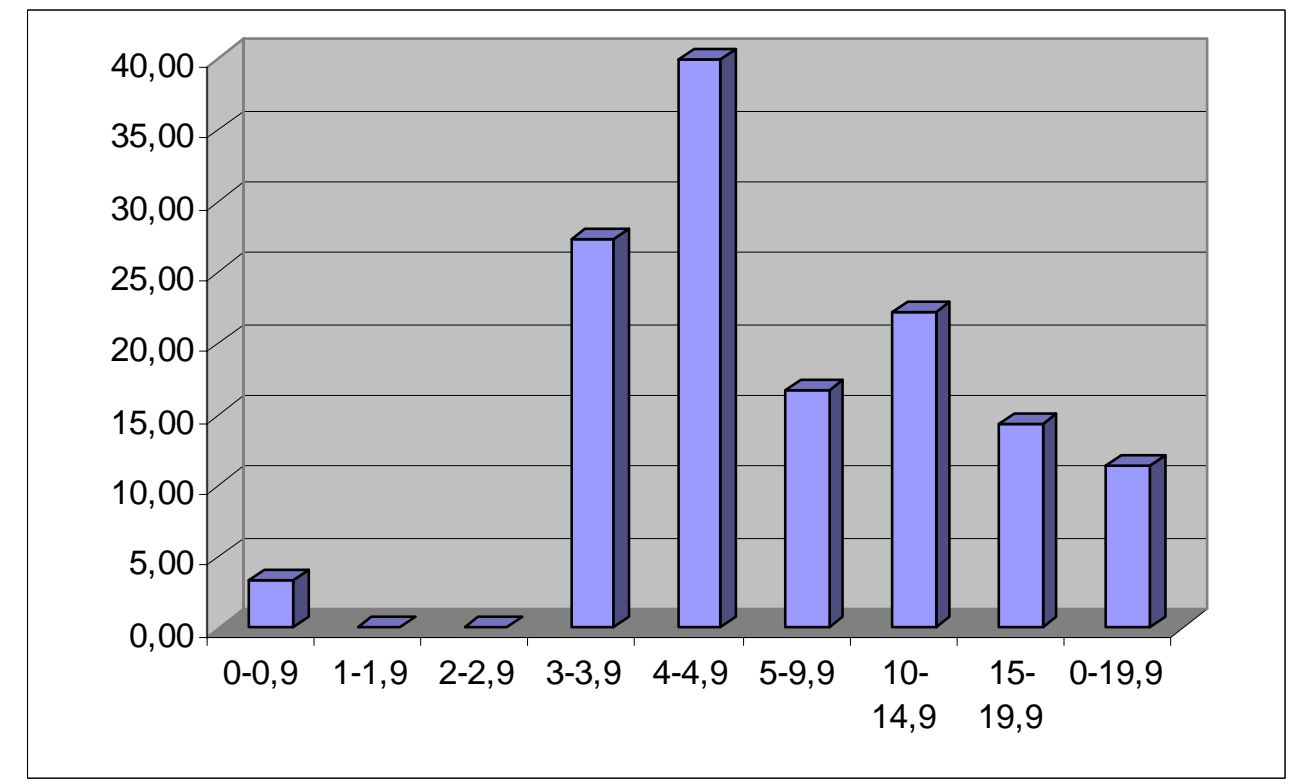

Figura 57 - Distribuição por faixa etária da porcentagem de indivíduos afetados por osteomielite localizada em San Pedro de Atacama.

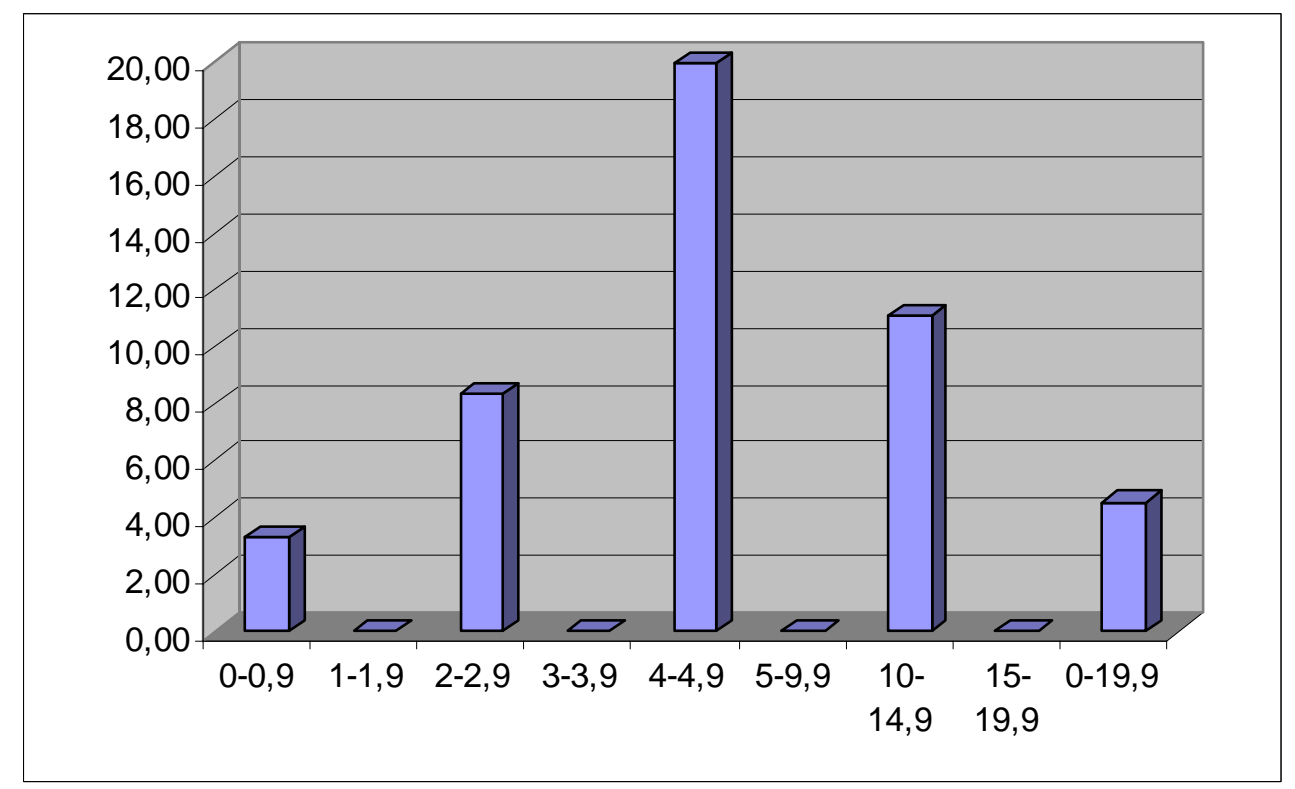

Figura 58 - Distribuição por faixa etária da porcentagem de indivíduos afetados por osteomielite extensa em San Pedro de Atacama. 


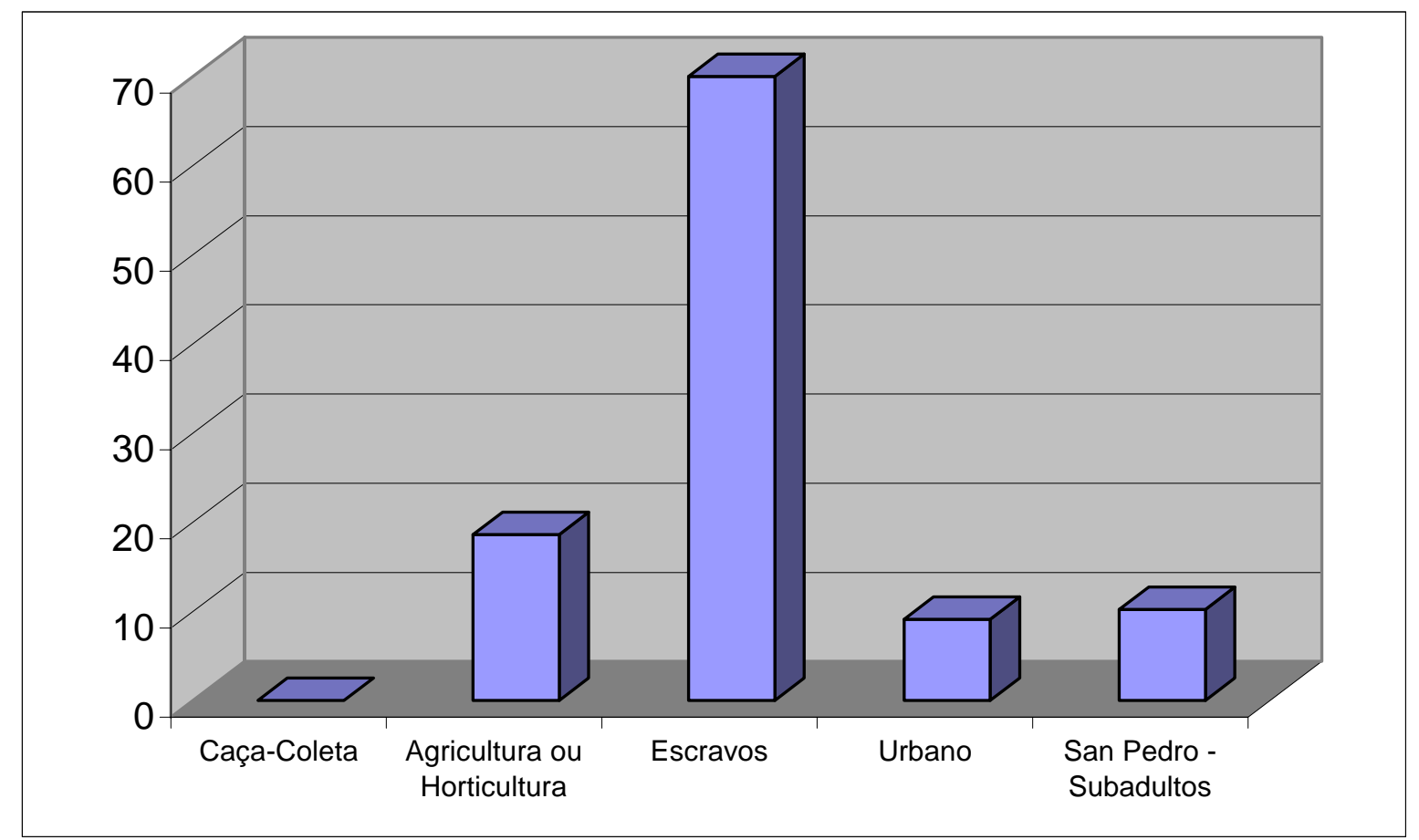

Figura 59 - Comparação da porcentagem de indivíduos afetados por periostite leve entre San Pedro de Atacama e as médias das diferentes subsistências.

comparando as médias de incidência de periostite leve entre os agricultores e os urbanos não apresentou resultado significativo, todavia $(\mathrm{P}=0,4987)$.

As infecções na tíbia apresentaram um valor bastante baixo em San Pedro de Atacama: setenta e um indivíduos apresentaram tíbias analisaveis e somente quatro mostraram-se afetados. A média dos caçadores-coletores (19,47\%) é a que mais se aproxima do valor de San Pedro (5,63\%). É importante destacar que todas as médias das populações mundiais apresentaram um alto desvio padrão (Tabela 108 e Figura 60). O teste não paramétrico de Kruskal-Wallis não apresentou resultados significativos, assim como os pós-testes de Dunn na comparação entre os pares de médias mundiais (Tabela 109).

A comparação direta das freqüências absolutas de San Pedo de Atacama com as diferentes estratégias de subsistência está apresentada nas Tabelas 110 e 111. Para periostite leve, apenas "urbano" não apresentou resultado significativo, enquanto que para infecções na tíbia, tanto "caça-coleta" como "mista" não apresentaram diferenças significativas. Para ambas as unidades de análise (periostite e tíbia) os subadultos de San 
Pedro de Atacama apresentaram baixo índice de infecções, com especial ênfase no baixo número de tíbias afetadas.

O índice de infecções em esqueletos subadultos do restante do mundo é semelhante ou mesmo mais alto que em esqueletos adultos (Tabelas 112 e 113). Dessa forma, o baixo índice de infecções nos subadultos de San Pedro de Atacama fica ainda mais evidente quando é comparado com os subadultos do restante do mundo. É importante destacar, todavia, que não foram encontradas na literatura incidências de infecções em subadultos de populações caçadoras-coletoras.

Tabela 109 - Valores de P do teste Kruskal-Wallis e dos pós-testes de Dunn, comparando as médias de indivíduos com tíbia infeccionada das diferentes subsistências.

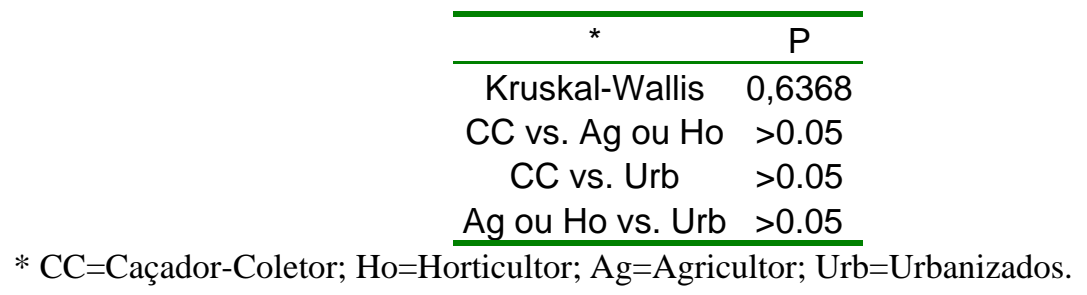

Tabela 110 - Comparação entre as freqüências absolutas (periostite leve) das diferentes estratégias de subsistência com San Pedro de Atacama, através do teste Qui-quadrado e Exato de Fisher (indivíduo como unidade de análise).

\begin{tabular}{cccccc}
\hline \multicolumn{6}{c}{ Estratégia de Subsistência Populações Frequência absoluta Porcentagem Qui-Quadrado (P)* Fisher (P)* } \\
\hline Caça-Coleta & 1 & $0 / 75$ & 0,00 & $\mathbf{0 , 0 1 2 2}$ & $\mathbf{0 , 0 0 3 9}$ \\
Agricultura ou Horticultura & 10 & $206 / 979$ & 21,04 & $\mathbf{0 , 0 2 2 4}$ & $\mathbf{0 , 0 1 2 6}$ \\
Escravo & 1 & $23 / 33$ & 69,70 & $<\mathbf{0 , 0 0 0 1}$ & $<0,0001$ \\
Urbano & 3 & $23 / 193$ & 11,92 & 0,8328 & 0,8399 \\
San Pedro de Atacama & & $9 / 88$ & 10,23 & & \\
\hline
\end{tabular}

* os valores em negrito foram considerados significativos 
Tabela 111 - Comparação entre as freqüências absolutas (infecção na tíbia) das diferentes estratégias de subsistência com San Pedro de Atacama, através do teste Qui-quadrado e Exato de Fisher (indivíduo como unidade de análise).

\begin{tabular}{cccccc}
\hline Estratégia de Subsistência Populações Frequência absoluta Porcentagem Qui-Quadrado $(\mathbf{P})^{*}$ Fisher $(\mathbf{P})^{*}$ \\
\hline Caça-Coleta & 3 & $28 / 187$ & 14,97 & 0,0686 & 0,0553 \\
Mista & 1 & $6 / 42$ & 14,29 & 0,2216 & 0,1700 \\
Agricultura ou Horticultura & 12 & $255 / 919$ & 27,75 & $<0,0001$ & $<0,0001$ \\
Urbano & 5 & $392 / 750$ & 52,27 & $<0,0001$ & $<0,0001$ \\
San Pedro de Atacama & & $4 / 71$ & 5,63 & & \\
\hline
\end{tabular}

* os valores em negrito foram considerados significativos

Tabela 112 - Incidência de infecções entre subadultos em diferentes populações mundiais.

\begin{tabular}{|c|c|c|c|c|c|c|c|c|}
\hline Série esqueletal & Subsistência* & Datação & $\begin{array}{c}\text { Periostite } \\
\text { Leve }\end{array}$ & $\%$ & Tibia & $\%$ & Referência & $\begin{array}{l}\text { Faixa } \\
\text { etária }\end{array}$ \\
\hline Copan rural, Maia & $\mathrm{Ag}$ & -1150-950 & $4 / 10$ & 40,00 & $4 / 7$ & 57,14 & Storey et al. (2002) & até 14 anos \\
\hline Copan urbano, Maia & $\mathrm{Ag}$ & $\sim 1150-950$ & $50 / 112$ & 44,64 & $25 / 54$ & 46,30 & Storey et al. (2002) & até 14 anos \\
\hline Jaina, Maia & $\mathrm{Ag}$ & $1350-950$ & $16 / 59$ & 27,12 & $22 / 43$ & 51,16 & Storey et al. (2002) & até 14 anos \\
\hline Xcaret, Maia & $\mathrm{Ag}$ & Pós-Clássico & $2 / 4$ & 50,00 & $2 / 3$ & 66,67 & Storey et al. (2002) & até 14 anos \\
\hline Tlatilco, México & $\mathrm{Ag}$ & $3350-2850$ & $27 / 57$ & 47,37 & $34 / 57$ & 59,65 & Morfin et al. (2002) & até 14 anos \\
\hline Cuicuilco, México & $\mathrm{Ag}$ & $2550-2100$ & $0 / 12$ & 0,00 & $4 / 12$ & 33,33 & Morfin et al. (2002) & até 14 anos \\
\hline Tlajinga, México & $\mathrm{Ag}$ & $1700-1350$ & $9 / 20$ & 45,00 & $6 / 20$ & 30,00 & Morfin et al. (2002) & até 14 anos \\
\hline Cholula, México & $\mathrm{Ag}$ & $1050-429$ & $40 / 82$ & 48,78 & $64 / 82$ & 78,05 & Morfin et al. (2002) & até 14 anos \\
\hline Negros de Cedar Groove, Arkansas, EUA & Urb & $50-35$ & & & $24 / 42$ & 57,14 & Davison et al. (2002) & \\
\hline Negros de Freedmans, EUA & Urb & $81-43$ & & & $80 / 124$ & 464,52 & Davison et al. (2002) & \\
\hline San Pedro - Subadultos & $\mathrm{Ag}$ & $1700-710$ & $9 / 88$ & 10,23 & $4 / 71$ & 5,63 & & até 20 anos \\
\hline
\end{tabular}




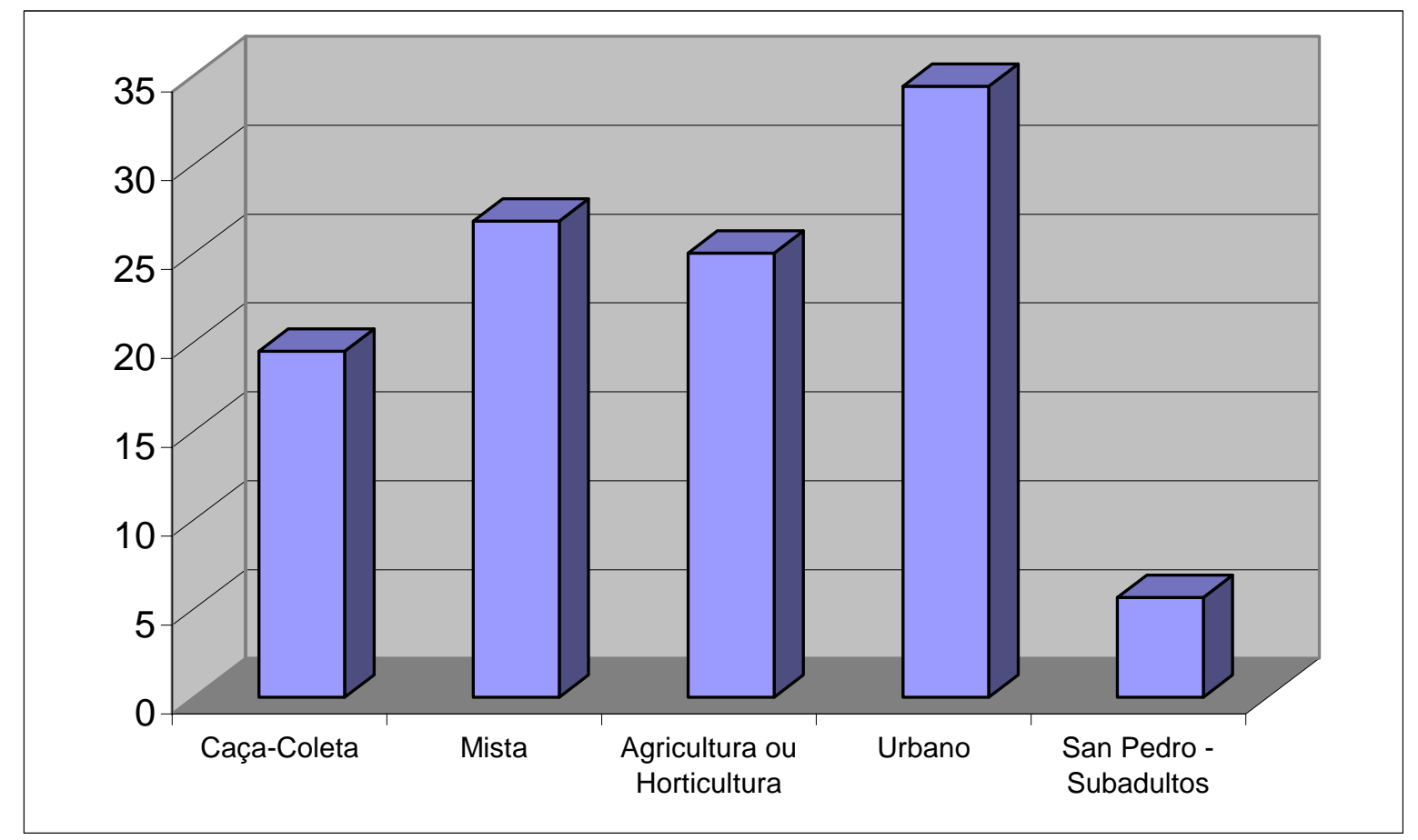

Figura 60 - Comparação da porcentagem de indivíduos com a tíbia infectada entre San Pedro de Atacama e as médias das diferentes subsistências.

\section{3 - Discussão}

\subsection{1 - Limitações da análise}

O levantamento das populações mundiais cobriu grande parte do planeta. Representantes de todos os continentes foram incluídos neste estudo, assim como populações de diferentes zonas climáticas. A faixa temporal variou de 12 mil anos até o presente. Esta ampla distribuição, no entanto, não se aplicou a todos os marcadores, nem a todas as estratégias de subsistência. O marcador traumas, por exemplo, tem poucas populações representadas (12), enquanto o marcador cáries é representado por 187 populações. Da mesma forma, agricultores estão mais representados que as demais estratégias de subsistência. Esta quebra da amostra mundial por categorias de subsistência fez com que algumas dessas categorias fossem representadas apenas por uma ou duas populações, prejudicando a confiabilidade das análises. A quebra da amostra total por método de análise também teve efeito negativo na representação das categorias sócioeconômicas. 
Um outro problema no levantamento das populações mundiais foi a acuidade da descrição dos contextos arqueológicos nos artigos consultados. Em muitos deles informações sobre a estratégia de subsistência eram bastante imprecisas, ou mesmo ausentes. Tal problema somou-se à dificuldade inerente a se categorizar uma população nas diferentes estratégias de subsistência. Existe, por exemplo, uma série de gradações entre caçador-coletor e agricultor. Assim como dentro de cada categoria é possível diferenciar diversos graus, como horticultores e agricultores. As categorias elencadas neste trabalho são bastante genéricas e amplas. São, no entanto, as únicas possíveis de serem adotadas tendo em vista a falta de rigor com que grande parte da literatura apresenta o contexto das coleções esqueletais examinadas.

A falta de comparabilidade entre os métodos foi também um importante entrave nesta análise. Marcadores como hipoplasia e infecções apresentaram bastante diversidade de tipos de análise na literatura, diminuindo consideravelmente o número de amostras passíveis de comparação. A falta de descrições detalhadas e critérios quanto à metodologia usada acentuaram ainda mais o problema, na medida em que impediram a indentificação de possíveis viéses metodológicos na variação dos resultados entre as populações mundiais.

O baixo número de estudos que se dedica exclusivamente aos subadultos, ou mesmo que apenas os apresentem como uma categoria à parte, também inseriu um viés nesta análise. Para alguns marcadores, os dados sobre adultos diferem substancialmente dos de subadultos (p.e. abcessos).

Por fim, é preciso enfatizar que o alcance das conclusões aqui obtidas é bastante restrito. Não foi possível realizar, por exemplo, testes de hipóteses refinadas sobre a ocorrência dos marcadores em diferentes climas e contextos sócio-culturais, pois os dados da literatura não permitiram tal refinamento.

\subsection{2 - Marcadores osteológicos}

A interpretação da incidência dos marcadores osteológicos seguiu a mesma postura adotada na comparação entre os períodos da pré-história atacamenha. A visão tradicional, na qual a incidência de esqueletos afetados corresponde à incidência da doença na população, foi adotada em contraposição ao “paradoxo osteológico”, que enuncia que 
problemas intrínsecos a qualquer amostra esqueletal conspiram contra a inferência de índices de qualidade de vida em uma população esqueletal (Wood et al., 1992). Apesar da adoção da visão tradicional, é inegável que fatores como mortalidade seletiva podem influir na comparação dos marcadores entre esqueletos adultos e subadultos. Tal viés pode resultar em índices de qualidade de vida biológica mais altos para os subadultos, já que os indivíduos acometidos por mais doenças tendem a morrer mais cedo. No entanto, alguns marcadores têm sua freqüência positivamente correlacionada com idade, com baixa incidência em subadultos. Consequentemente, sempre que possível foi priorizada a comparação dos dados dos subadultos de San Pedro de Atacama com subadultos do restante do mundo.

Os resultados obtidos nesta análise foram interpretados a partir de quatro perguntas centrais, que buscaram caracterizar o estilo e a qualidade de vida biológica dos subadultos de San Pedro de Atacama no contexto mundial. As quatro perguntas foram respondidas para cada um dos marcadores. 1) O marcador osteológico distingue com clareza as diferentes estratégias de subsistênca? Ou seja, se as estratégias de subsistência podem ser consideradas categorias discretas para tal marcador osteológico. 2) Os dados sobre San Pedro se ajustam à estratégia de subsistência agricultora? 3) A incidência do marcador é mais alta ou mais baixa em relação à média dos agricultores? 4) Por que? É importante frisar que as respostas das questões 1 e 2 são independentes. No entanto, se a resposta da primeira pergunta for não, a confiança na resposta da segunda torna-se muito precária.

\subsection{3 - Hipoplasias lineares do esmalte dentário}

A variação dentro de cada estratégia de subsistência é muito alta quanto a esse marcador. Existe uma grande sobreposição entre as categorias, devida ao alto desvio padrão de cada uma delas. A única distinção estatísticamente significativa entre as estratégias de subsistência foi na análise por indivíduo entre “caçador-coletor” e "urbano”, na qual o primeiro apresentou valores mais altos. Além disso, a estratégia de subsistência caçadoracoletora apresentou valores mais altos que as agricultoras na comparação das médias, usando-se indivíduo como unidade e na comparação direta das freqüências absolutas em todas as unidades de análise. Tal quadro é inverso ao que está estabelecido na literatura 
(Larsen, 1997). Portanto, o marcador hipoplasia não parece distinguir claramente as diferentes estratégias de subsistência.

Os dados sobre hipoplasia nos subadultos de San Pedro não se ajustam à estratégia de subsistência agricultora. Os valores estão pelo menos um desvio padrão acima da média dos agricultores, assim como são estatisticamente distintos quanto à comparação direta das freqüências absolutas usando indivíduo, dente e canino inferior como unidade. Se compararmos com os dados dos subadultos do restante do mundo, os valores de San Pedro de Atacama são os maiores até agora reportados.

A incidência de hipoplasias em San Pedro de Atacama é alta em relação aos dados mundiais possivelmente devido à sua situação geográfica. San Pedro de Atacama localizase em uma região marginal em relação à disponibilidade de recursos. A escassez de água e o clima desértico são fatores ambientais que aumentam o estresse. Fatores culturais não podem ser afastados completamente da explicação, mas o fato dos dados de San Pedro de Atacama abarcarem diferentes fases culturais sugere a geografia como o elemento constante.

\subsection{4 - Abcessos}

A incidência de abcessos, usando-se alvéolo como unidade, revelou valores muito próximos para as diferentes estratégias de subsistência. Tal conformação impediu distinção estatística entre as suas médias. Já a análise usando indivíduo como unidade apresentou médias mais distanciadas entre as estratégias de subsistência, detectando-se diferença estatísticamente significativa entre caçadores-coletores e agricultores (os primeiros com média mais alta). A tendência para abcessos nessas duas estratégias de subsistência não é tão clara na literatura; em contrapartida, os dados para perda de dentes e periodontite apontam para uma maior incidência entre agricultores (Larsen, 1997). Como os abcessos apresentam uma correlação etiológica com esses dois marcadores, é possível predizer que agricultores teriam mais abcessos que caçadores-coletores. No entanto, os dados mundiais evidenciaram os agricultores com menos abcessos, contradizendo a previsão inicial. De qualquer forma, a análise por indivíduo parece distinguir melhor as categorias de subsistência que a análise por alvéolo. 
Os dados de San Pedro de Atacama se adequam à estratégia de subsistência agricultora na análise por indivíduo, mas não por alvéolo. A incidência de abcessos em San Pedro, usando alvéolo como unidade, é baixa em relação à amostra mundial de esqueletos adultos de populações agricultoras. Entretanto, os dados mundiais de abcessos para esqueletos subadultos, usando-se alvéolo como unidade, mostraram que San Pedro de Atacama tem alta incidência da patologia, em contradição com a comparação de San Pedro com adultos do restante do mundo. A provável explicação para essa contradição é que “abcesso” é um marcador positivamente correlacionado com idade (Hillson, 1996; ver Capítulo 4). Tendo em vista a discordância, foi dada primazia à comparação com subadultos, que caracteriza a ocorrência de abcessos em San Pedro como alta.

O alto índice de abcessos nos subadultos de San Pedro de Atacama parece ter correlação com o alto índice de cáries (ver a seguir), que é um dos fatores preponderantes no aparecimento da patologia. O tipo de alimento que gerou esse padrão foi possivelmente o milho e seus derivados, já que esse era o principal cultivo dos agricultores atacamenhos. A batata e os melados de chañar e agarrobo também podem ter contribuído para esse alto índice de abcessos (Llagostera et al., 2004).

\subsection{5 - Cáries}

Cárie foi o marcador osteológico que melhor diferenciou as estratégias de subsistência. Além disso, os agricultores apresentaram maior freqüência absoluta de cáries (estatisticamente significativa) que os caçadores-coletores, como é estabelecido na literatura (Larsen, 1997). É possível que o maior tamanho amostral (187 populações) tenha sido um fator importante para a distinção clara entre as estratégias de subsistência.

A análise por dente mostrou a incidência de cáries dos subadultos de San Pedro muito próxima da média dos agricultores em geral. Já a comparação direta das freqüências absolutas só não diferenciou estatisticamente San Pedro de Atacama e a população pastoralista. Na análise por indivíduo, a incidência de San Pedro está um desvio padrão acima da média dos agricultores. Da mesma forma, na comparação direta das freqüências absolutas, San Pedro só não se diferencia estatisticamente dos agricultores. Apesar de se 
encontar dentro da variação dos agricultores, as cáries em San Pedro se encontram no extremo mais alto dessa distribuição.

Uma possível explicação para os altos valores de cáries em San Pedro de Atacama (só é mais baixo que nas populações urbanas) está ligada à alta quantidade de carboidratos ingeridos. A quantidade de açúcares consumida é o fator preponderante para a incidência de cáries - porém não exclusivo (Touger-Decker e Loveren, 2003). A alimentação baseada em preparados de milho pode ser uma explicação putativa para esses altos valores.

\subsection{6 - Traumas}

O levantamento de populações mundiais para o marcador trauma resultou em um número muito baixo de estudos de caso (12). As médias das estratégias de subsistência não apresentaram diferença estatisticamente significativa quando comparadas pelo teste ANOVA não paramétrico; o pequeno tamanho amostral pode ter causado esse resultado. A categoria “caçador-coletor” (representada por apenas uma população) apresentou índice de traumas muito superior ao dos agricultores. Tal tendência corrobora a literatura estabelecida para traumas (principalmente os pós-cranianos), os quais ocorrem em maior quantidade em caçadores-coletores, já que essas populações apresentam maior esforço físico e exposição ao meio se comparadas com agricultores, por exemplo (Larsen, 1997).

A incidência de traumas nos subadultos de San Pedro de Atacama está abaixo da população com o menor valor entre os agricultores. Na verdade, os traumas na população subadulta de San Pedro são menos frequentes que qualquer média das estratégias de subsistência.

A partir desses dados é possível concluir que a taxa de engajamento em conflitos, de abuso físico e de acidentes domésticos envolvendo subadultos era muito baixa, se considerarmos ainda que o único indivíduo com ocorrência de trauma tinha 14 anos. No entanto, é preciso ter cautela quanto a esses dados, já que não foram encontrados dados exclusivos para subadultos na literatura. O que é certo é que a população subadulta de San Pedro sofria poucos acidentes traumáticos em relação aos adultos do resto do mundo. Os adultos da população de San Pedro de Atacama, inclusive, têm índices mais altos de 
traumas cranianos (Torres-Rouff e Costa, 2006) e pós-cranianos (Neves et al., 1999) que os subadultos aqui analisados.

\subsection{7 - Hiperostose porótica}

A incidência de hiperostose varia bastante nas diferentes estratégias de subsistência. O desvio padrão de cada uma delas é grande, assim como a zona de sobreposição de seus valores. Apesar dessa alta variabilidade dentro de cada estratégia de subsistência, a média dos agricultores é mais alta que a média dos caçadores-coletores (sem significância estatística), concordando de certa forma com o padrão estabelecido pela literatura (Larsen, 1997).

A incidência de cribra orbitalia nos subadultos de San Pedro de Atacama está um pouco abaixo de um desvio padrão em relação à média dos subadultos dos agricultores em geral. Em contrapartida, San Pedro se aproxima da média dos agricultores quando as incidências de hiperostose porótica (subadultos mais adultos) são comparadas. Da mesma forma, a comparação direta das freqüências absolutas não indicou diferença significativa entre San Pedro e populações agricultoras para hiperostose porótica. Nesse caso, assim como nos abcessos, priorizaram-se os dados comparativos de subadultos, já que é consagrado na literatura que as crianças são mais atingidas por essa patologia (StuartMacadam, 1985).

Os valores de San Pedro podem, então, ser caracterizados como baixos em relação à amostra mundial. Tal constatação é reforçada pela comparação mais minuciosa da ocorrência de hiperostose porótica (cribra e calota) por faixa etária com populações agricultoras e uma população na transição da caça-coleta para a agricultura. Os valores foram significativamente mais baixos. A única ressalva a esta tendência é a freqüência ligeiramente mais alta de hiperostose na calota em relação à órbita em San Pedro, situação incomum em outras populações.

A explicação para essa baixa ocorrência debe estar ligada às condições geográficas de San Pedro de Atacama. A grande altitude e a baixa disponibilidade de água fazem com que parasitismo seja menos frequente (Stuart-Macadam, 1992). Sabendo-se que parasitismo é um dos elementos envolvidos no desenvolvimento de hiperostose, é comum a baixa 
presença desse marcador em regiões deséricas (Blom et al., 2005). A baixa incidência de infecções bacterianas e virais (ver a seguir) também deve ter contribuido para esse quadro, já que diarréia ${ }^{4}$, por exemplo, prejudica a absorção de nutrientes como o ferro, cuja ausência é responsável pelo desenvolvimento da hiperostose porótica (Sullivan, 2005).

\subsection{8 - Infecções inespecíficas}

Seguindo o mesmo padrão de quase todos os marcadores osteológicos aqui analisados, "infecções" mostrou uma alta variação entre as estratégias de subsistência. Devido ao alto desvio padrão apresentado por cada estratégia, não se detectou diferença estatísticamente significativa entre as estratégias de subsistência. Ainda assim, foi possível observar que agricultores apresentam maior incidência de infecções que caçadorescoletores, em concordância com o estabelecido na literatura (Larsen, 1997).

A incidência de infecções em San Pedro de Atacama apresentou diferença significativa com agricultores quando comparados pela freqüência absoluta. Porém, é importante ressaltar que a categoria "agricultor" apresentou alta variabilidade entre as populações nela representadas. Os valores de San Pedro localizam-se no extremo mais baixo da distribuição de agricultores, com especial destaque para as infecções na tíbia, com apenas 5,63\% dos indivíduos afetados.

A explicação para essa baixa incidência de infecções reside em dois fatores principais e inter-relacionados. O primeiro deles refere-se à baixa disponibilidade hídrica no Deserto de Atacama. Em regiões mais secas, patógenos em geral têm dificuldades em sobreviver e proliferar. O segundo fator é a baixa densidade populacional das regiões desérticas. $\mathrm{O}$ ambiente apresenta recursos muito limitados, sustentando apenas tamanhos populacionais pequenos. A baixa densidade de pessoas reduz a capacidade de transmissão das doenças, além de desfavorecer o acúmulo acentuado de dejetos próximos aos locais de habitação (Goodman e Martin, 2002).

\footnotetext{
${ }^{4}$ Diarréia pode ser de origem viral, bacteriana ou protozoária. Somente no terceiro caso a diarréia é considerada de origem parasitária (Moffat, 2003).
} 


\section{4 - Síntese}

Abaixo estão resumidas as principais conclusões obtidas na análise mundial:

1) Á exceção das cáries, a distribuição mundial dos marcadores osteológicos apresentou alta variação dentro das estratégias de subsistência, alta sobreposição de valores e poucas diferenças estatisticamente significativas entre elas.

2) As incidências dos marcadores nos subadultos de San Pedro de Atacama tenderam a se distanciar da média das populações agricultoras em geral. No entanto, devido à alta variabilidade entre as populações agricultoras, os valores de San Pedro ainda se encontram dentro de dois desvios padrões da média.

3) Os dados mundiais para os marcadores hipoplasias e abcessos apresentam caçadores-coletores com valores mais altos que agricultores. Tal informação contraria o estabelecido tradicionalmente na literatura, ou seja, que agricultores têm pior qualidade de vida biológica que caçadores-coletores quando estes marcadores são analisados (Larsen, 1997).

4) A incidência dos marcadores cáries, abcessos e hipoplasias em San Pedro de Atacama ficaram acima da média dos agricultores. Os dois primeiros estão certamente relacionados com alto consumo de carboidratos, enquanto o terceiro está provavelmente ligado à marginalidade ambiental da região, com baixa disponibilidade de recursos e, portanto, favorável a situações de estresse biológico.

5) A incidência dos marcadores hiperostose porótica, infecções e traumas em San Pedro de Atacama ficaram abaixo da média dos agricultores. As duas primeiras são devidas muito provavelmente à baixa disponibilidade hídrica e à grande altitude, que desfavorecem a proliferação de parasitas e a dispersão de doenças. A terceira é devida a uma baixa ocorrência de conflitos, de acidentes cotidianos e de abuso físico parental nos subadultos em San Pedro. 


\section{Capítulo 6 - Discussão e conclusão}

\section{1 - Relação centro-periferia}

Os resultados das incidências dos marcadores osteológicos estudados na população subadulta de San Pedro de Atacama foram bastante variados. As tendências dos marcadores não apresentaram uma coerência entre si; cada um deles apontou direções diferentes. $\mathrm{O}$ sítio Solcor-3 Tiwanaku, sob a influência do Império, apresentou alta incidência de infecções e de hiperostose porótica e baixa incidência de cáries, enquanto o restante dos marcadores ocupou uma posição intermediária em relação aos outros períodos. Tal quadro é desfavorável à hipótese inicial, à exceção das cáries, de que a influência do Império Tiwanaku melhorou a qualidade de vida biológica da população atacamenha. O que se verificou, de fato, foi uma alteração nos índices de qualidade de vida, porém em diferentes direções, dependendo do marcador. A partir desses dados, o que se pode inferir sobre a relação entre San Pedro e o Império Tiwanaku?

Um ponto importante para essa questão é a mudança paradigmática que vem envolvendo os estudos das relações centro-periferia. O modelo clássico dessa relação é o Sistema Mundial de Wallerstein (1974). Ele foi criado, inicialmente, para explicar a relação entre os países atuais, porém, a revelia de seu autor, foi logo transposto para os estudos arqueológicos. O Sistema Mundial foi uma reformulação do modelo de dependência criado por Frank (1967), que foi o primeiro a estabelecer uma distinção clara entre o centro e a periferia. A idéia central do modelo clássico é a existência de uma relação assimétrica. O centro é manufaturador de produtos de alto valor, enquanto a periferia é exportadora de matéria-prima. Conceitos como divisão internacional do trabalho, colonialismo e aculturação estão conectados ao funcionamento do Sistema Mundial. O centro exerce uma influência em todas as esferas das sociedades dominadas, enquanto a periferia é encarada como um recipiente de idéias e produtos; estabelece-se uma relação assimétrica e, preponderantemente, unidirecional (Stein, 2002).

Diversas críticas foram formuladas ao Sistema Mundial tanto na arqueologia como na política, na sociologia e na antropologia. Essas críticas buscaram identificar novas variáveis no sistema. Entre essas inovações pode-se citar a dependência das elites do centro 
de bens de distinção vindos da periferia, a variabilidade da relação centro-periferia dependendo da área em questão e a reorganização das populações periféricas a partir do domínio do Império. Apesar de todos esses refinamentos, até o meio da década de 1990 ainda não havia um rompimento definitivo com as premissas básicas do Sistema Mundial (Jennings, 2006).

A mudança paradigmática só ocorreu quando dois pontos cruciais foram estabelecidos. Em primeiro lugar, a afirmação da heterogeneidade da composição interna de uma sociedade. Conflitos de interesse entre grupos, manifestos através de diferentes alianças, práticas e ideologias, são elementos preponderantes nas relações inter regionais. Em outras palavras, houve uma mudança de foco das relações estritamente externas para uma compreensão da diversidade interna das sociedades. Foi o fim do centro e da periferia como categorias monolíticas e claramente distintas. O segundo ponto foi a mudança de ênfase da relação centro-periferia - seja ela direta ou indireta - para as relações regionais. Quando um Império se estabelece, ele ocasiana a reformulação de toda uma rede de interações regionais, que antes era negligenciada pelos estudiosos, ou pelo menos, deixadas em segundo plano. Dentro do paradigma do Sistema Mundial, o eixo principal de pesquisa era a relação centro-periferia, já na nova proposta, as coligações regionais ganham muito mais importância. A relação periferia com periferia passou a ter destaque nos modelos explicativos.

Dois exemplos de aplicação desses princípios se encontram nos trabalhos de Stein (2002) e Jennings (2006). O primeiro deles aplica o conceito de diáspora autônoma para a ocupação da periferia do Império Uruk no sudeste da Anatólia (atual Turquia) há cerca de 6000 BP. O segundo mostrou como os assentamentos do Vale Cotahuasi no sul do Peru se reestruraram regionalmente durante o Horizonte Médio (1400-1000 BP). Esse período foi marcado pelo estabelecimento do Império Wari na região.

Os estudos da relação centro-periferia no Impéio Tiwanaku também acompanharam essa mudança de paradigma (descrições detalhadas das idéias dos autores estão no Capítulo 2 deste trabalho). Na década de 1970 e 1980, autores como David Browman e Dwight Wallace enfatizavam a assimetria da troca entre centro e periferia, tanto no aspecto econômico como no âmbito simbólico. Já na década de 1990, ao refinar modelos anteriores, o trabalho de Berenguer (1998) procurou enfatizar a diferença da influência do Império 
Tiwanaku em distintas regiões de sua periferia. Todavia, foi somente com trabalhos como os de Albarracin-Jordan (1996) e Janusek (2002) que a mudança de paradigma se fez de fato presente no estudo de Tiwanaku. Esses trabalhos buscaram enfatizar a diversidade e a heterogeneidade do centro do Império, trabalhando com os jogos de poder entre os grupos familiares (ayllus) e a elite dominante.

A partir dessa sucinta caracterização das mudanças sobre a compreensão da relação centro-periferia nas últimas três décadas, é possível retornar à questão formulada. Como os dados deste trabalho podem esclarecer a relação entre Tiwanaku e San Pedro?

Em primeiro lugar é preciso destacar que a compreensão da relação entre centro e periferia foi e deve ser compreendida preponderantemente a partir de dados arqueológicos. Os modelos que foram desenvolvidos para elucidar essa questão são baseados em padrões de distribuição da cultura material encontrada em sítios arqueológicos (ainda que a origem desses modelos possa ter vindo de outras áreas, como a sociologia e a antropologia). Os estudos com esqueletos humanos seriam, portanto, apenas um elemento a mais na composição dos modelos, não podendo gerar conclusões desconectadas do contexto arqueológico. Tal ressalva é importante aqui porque não está no âmbito deste trabalho responder à questão de qual era a natureza da relação entre San Pedro e Tiwanaku, mas sim inserir a perspectiva da qualidade de vida biológica a esse contexto.

Infelizmente, os novos modelos teóricos desenvolvidos para compreender a relação entre centro e periferia não têm inserido a perspectiva bioantropólogica no problema, o que talvez se justifique pela juventude dessas novas abordagens. Quais seriam as conseqüências na qualidade de vida biológica dos diferentes tipos de relação entre centro e periferia e das novas conexões regionais? Será que o Império sempre piora a qualidade de vida biológica da população na periferia? Essas questões ainda estão em aberto, uma vez que os novos modelos arqueológicos estão começando a produzir dados sob o novo paradigma.

O que se sabe, de fato, vem de um outro tipo de abordagem, bastante consagrada na literatura bioantropológica: a relação entre qualidade de vida e sistemas de subsistência. Livros capitais como o Bioarchaeology de Clark Larsen e The Backbone of History organizado por Richard Steckel e Jerome Rose fornecem dados que apontam para uma piora de qualidade de vida biológica com o advento da agricultura. Ao analisar populações pré-históricas do hemisfério ocidental, Steckel et al. (2002) detectaram uma diminuição 
progressiva da qualidade de vida (baseada em um índice de saúde) quanto mais recente a população. Fatores como o aumento de densidade populacional, o maior contato com animais domésticos, o estilo de vida e a dieta agricultora foram levantados como causas dessa piora (Larsen, 1997).

Apesar da abordagem acima ser bastante elucidativa sobre os padrões de mudança entre duas estratégias de subsistência, ela não explica a diversidade dos dados dentro de cada uma delas (ver Capítulo 5), nem a divergência dos marcadores osteológicos dentro de uma sociedade específica. A abordagem está mais focada em padrões amplos e universais, e não nas causas de variação nas configurações locais.

A partir dessa abordagem universalizante, poderíamos presumir que se o Império está intimamente ligado ao aumento da densidade populacional e à intensificação da agricultura, a qualidade de vida biológica, consequentemente, pioraria. A formação do Império Tiwanaku e sua expansão, por exemplo, geraram aumento de densidade populacional e intensificação da agricultura em San Pedro de Atacama (Llagostera e Costa, 1999). Essas transformações, dentro do modelo universalizante, estariam associadas à dimuinuição da qualidade de vida biológica. No entanto, não é isso que os dados deste trabalho mostram.

Para respondermos à pergunta que estrutura esta discussão, é preciso voltar aos modelos arqueológicos que vem caracterizando a mudança paradigmática na compreensão das relações entre o centro e a periferia. Esses modelos enfatizam as conexões regionais, as mudanças sociais internas e a variabilidade de relações dentro de um mesmo Império. Os dados dos subadultos de San Pedro de Atacama mostram um padrão muito próprio de mudança na região, sob o qual houve melhora em certos aspectos e piora em outros durante a influência do Império Tiwanaku. Na esfera da dieta especificamente, parece ter havido um aumento do consumo de carne e conseqüente diminuição dos alimentos com alto teor de carboidratos. Na esfera dos patógenos, parece ter havido um aumento de infecções (e de hiperostose porótica), possivelmente como conseqüência de um aumento da densidade populacional local e de um mais intenso contato com as populações vizinhas. Já na esfera da violência inter-pessoal e dos acidentes cotidianos, a incidência de traumas nos subadultos se mostrou inalterada em relação aos períodos vizinhos. 
Em síntese, a influência do Império Tiwanaku reestruturou o estilo de vida atacamenho, seja através de uma influência direta do centro do Império, seja através de uma reacomodação das conexões regionais. A sociedade atacamenha experimentou uma mudança no seu modo de vida que resultou em perdas e ganhos, dependendo da esfera analisada. Os modelos arqueológicos sobre a relação entre centro e periferia sob o novo paradigma parecem ser mais sensíveis à singularidade e à variabilidade, evitando o estabelecimento de padrões universais muito rígidos. No entanto, os novos modelos arqueológicos continuam carecendo da inserção de dados bioarqueológicos. Desta forma, este trabalho buscou não só revelar as mudanças da qualidade de vida biológica na préhistória atacamenha, como, também, servir de fonte de dados para futuras elaborações de modelos arqueológicos.

\section{2 - Análise mundial}

A comparação com outras amostras por estratégia de subsistência não foi adequada para entender as nuânces e configurações particulares da pré-história atacamenha. Todavia, as grandes comparações podem também trazer informações valiosas, mesmo que em um nível mais geral. Visto a escassez de dados contextuais de muitos artigos da literatura sobre marcadores osteológicos, a comparação por grandes estratégias de subsistência é uma alternativa viável para utilizar essa informação disponível.

Uma série de estudos tem adotado essa linha de pensamento. Um livro proeminente nessa direção é The Backbone of History organizado por Richard Steckel e Jerome Rose. Steckel et al. (2002), baseados nos dados do livro, buscaram estabelecer padrões temporais, ecológicos e geográficos para os índices de saúde de várias populações do hemisfério ocidental. Populações móveis, vivendo na costa e sem domesticação, apresentaram os melhores índices, enquanto agricultores de grande altitude tiveram os piores índices. Esse tipo de estudo traz importantes contribuições para uma visão geral da saúde das populações humanas ao longo do tempo decorrente das grandes inovações sociais e tecnológicas, porém tem a desvantagem de adotar um índice geral e inclusivo de saúde ao invés de trabalhar separadamente com cada um dos marcadores osteológicos. 
Os trabalhos de Larsen (1997) e Ubelaker (2000), por outro lado, mostraram a enorme variabilidade das freqüências dos marcadores ao redor do mundo, ainda que trabalhando sob a perspectiva das grandes comparações mundiais. O segundo trabalho, por exemplo, mostrou que fatores temporais e geográficos interagem para formar um padrão complexo de incidência dos marcadores osteológicos nas diferentes populações mundiais.

Os dados gerados neste trabalho mostraram a grande variabilidade existente entre e dentro das estratégias de subsistência, à exceção das cáries, o único marcador que apresentou uma distinção nítida entre as estratégias de subsistência. Apesar disso, os dados mostraram também que nem sempre caçadores-coletores apresentam melhor qualidade de vida biológica que os agricultores (no caso de abcessos e hipoplasias). Os resultados dos subadultos de San Pedro de Atacama no geral os aproximam da categoria agricultores, porém, não precisamente sobre a média. Três marcadores situaram-se acima da média agricultora (cáries, abcessos e hipoplasias) e três deles situaram-se abaixo (infecções, hiperostose porótica e traumas). Características alimentares e geográficas explicam esses resultados. San Pedro de Atacama localiza-se em uma região de grande altitude, baixa disponibilidade hídrica, relativo isolamento, tendo o milho como plantação principal.

Por fim, é importante enfatizar que a análie mundial mostrou grandes tendências, valendo-se de simplificações metodológicas e contextuais. Essas tendências devem ser analisadas mais a fundo no futuro, através de comparações mais refinadas que utilizem estudos bem contextualizados. A profundidade na investigação local é fundamental para que as grandes comparações mundiais obtenham resultados refinados. Dessa forma, este trabalho buscou prover a literatura de uma análise regional detalhada para que novos trabalhos comparativos possam ser enriquecidos. A integração de uma análise regional com uma comparação mundial é a forma mais rica de explorar as diversas dimensões interpretativas dos marcadores osteológicos de estilo e qualidade de vida biológica. 


\section{Referências Bibliográficas}

Albarracin-Jordan J (1996) Tiwanaku settlement system: the integration of nested hierarchies in the lower Tiwanaku valley. Latin American Antiquity 7:183-210.

Angel JL (1966) Porotic hyperostosis, anemias, malarias, and marshes in the prehistoric eastern mediterranean. Science 153:760-763.

Beiguelman B (2002) Curso prático de bioestatística. FUNPEC - editora.

Bello SM, Thomann A, Signoli M, Dutour O, and Andrews P (2006) Age and sex bias in the reconstruction of past population structure. American Journal of Physical Anthropology 120:24-38.

Bennike P, Lewis ME, Shutkowski H, and Valentin F (2005) Comparison of child morbidity in two contrasting medieval cemeterie from Denmark. American Journal of Physical Anthropology 128:734-746.

Berenguer J (1998) La iconografia del poder em Tiwanaku y su rol en la integracion de zonas de frontera. Boletin del museo chileno de arte precolombino 7:19-37.

Berenguer J (2000) Tiwanaku: señores del lago sagrado. Santiago: Museo Chileno de Arte Precolombino.

Berenguer J, Castro V, and Silva O (1980) Reflexiones acerca de la presencia de Tiwanaku en el norte de Chile. Estudios Arqueológicos 5:81-93.

Berenguer J, Deza A, Román A, and Llagostera A (1986) La secuencia de Myriam Tarragó para San Pedro de Atacama: un test por termoluminiscencia. Revista Chilena de Antropologia 5:17-54.

Berger TD, and Trinkaus E (1995) Patterns of trauma among the neandertals. Journal of Archaeological Science 22:841-852.

Binford LR (1962). Archaeology as anthropology. American Antiquity 28(2):217-225.

Binford MW, Kolata AL, Brenner M, Janusek JW, Seddon MT, Abbott M, and Curtis JH (1997) Climate variation and the rise and fall of an andean civilization. Quaternary Research 47:235-248.

Blakey ML, Leslie TE, and Reidy JP (1994) Frequency and cronological distribution of dental enamel hypoplasia in enslaved african americans: a test of the weaning hypothesis. American Journal of physical Anthropology 95:371-383. 
Blom DE (2005) Embodying borders: human body modification and diversity in Tiwanaku society. Journal of Anthropological Archaeology 24:1-24.

Blom DE, Buikstra JE, Keng L, Tomczak PD, Shoreman E, and Stevens-Tuttle D (2005) Anemia and childhood mortality: Latitudinal patterning along the coast of pre-Columbian Peru. American Journal of Physical Anthropology 127:152-169.

Bogin B (1988) Patterns of human growth. Cambridge: Cambridge University Press.

Browman DL (1980) Tiwanaku expansion and altiplano economic patterns. Estudios Arqueológicos 5:107-120.

Buikstra JE, and Cook DC (1980) Palaeopathology: an american account. Annual Review of Anthropology 9:433-470.

Buikstra JE, and Ubelaker DH (1994) Standards for data collection from human skeletal remains.

Burrell LL, Maas MC, and Van Gerven DP (1986) Patterns of long-bone fracture in two Nubian cemeteries. Human Evolution 1:495-506.

Callegari-Jacques SM (2003) Bioestatística: princípios e aplicações. São Paulo: Artmed Editora SA.

Carlson DS, Armelagos GJ, and van Gerven DP (1974) Factors influencing the etiology of cribra orbitalia in prehistoric Nubia. Journal of Human Evolution 3:405-410.

Carrasco C (2003) Los artefactos de molienda durante los períodos Intermedio Tardío y Tardío en San Pedro de Atacama y Loa Superior. Estudios Atacameños 25:35-53.

Cavalli-Sforza LL, Menozzi P, and Piazza A (1994) The history and Geography of human genes. Princeton: Princeton University Press.

Clarke NG (1990) Periodontal defects of pulpal origin: evidence in early man. American Journal of Physical Anthropology 82:371-376.

Cocilovo JA, Varela HH, and Quevedo S (1995) La deformación artificial del cráneo de la población prehistórica de San Pedro de Atacama, Chile. Chungara 27:117-124. 
Cockburn TA (1971) Infectious diseases in ancient populations. Current Anthropology 12:45-62.

Cohen MN (1994) The osteological paradox reconsidered. Current Anthropology 35:629631.

Cohen MN (1995) On paleopathology: reply to Wood and Milner. Current Anthropology 36:495.

Cohen MN, and Armelagos GJ, editors (1984). Paleopathology at the origins of agriculture. New York: Academic Press.

Corruccini RS, Handler JS, Mutaw RJ, and Lange FW (1982) Osteology of a slave burial population from Barbados, West Indies. American Journal of Physical Anthropology 59:443-459.

Costa-Junqueira MA (1988) Recontitución física y cultural de la población tardía del cementerio de Quitor-6 (San Pedro de Atacama). Estudios Atacameños 9:99-126.

Costa-Junqueira MA, and Llagostera A (1994) Coyo-3: momentos finales del período medio en San Pedro de Atacama. Estudios Atacameños 11:73-107.

Costa-Junqueira MA, and Neves WA (1990) Osteobiography and late agriculture social organization at San Pedro de Atacama, Chile. Apresentado no $59^{\circ}$ congresso anual da American Association of Physical Anthropologists, Miami.

Costa-Junqueira MA, Llagostera A, Rothhammer F, and Silva C (1995) Microdiferenciación craneométrica entre poblaciones agroalfareras de San Pedro de Atacama, Chile. Hombre y Desierto: una perspectiva cultural 9:27-31.

Costa-Junqueira MA, Neves WA, Barros AM, and Bartolomucci R (1998) Trauma y estrés en poblaciones prehistóricas de San Pedro de Atacama, norte de Chile. Chungara 30:65-74.

Costa-Junqueira MA, Neves WA, and Hubbe M (2004) Influencia de Tiwanaku en la calidad de vida biológica de la población prehistórica de San Pedro de Atacama. Estudios Atacameños 27:103-116.

Cucina A (2002) Brief communication: diachronic investigation of linear enamel hypoplasia in prehistoric skeletal samples from Trentino, Italy. American Journal of Physical Anthropology 119:283-287.

Cucina A, and Tiesler V (2003) Dental caries and antemorten tooth loss in the Northern Peten Area, Mexico: a biocultural perspective on social status differences among the Classic Maya. American Journal of Physical Anthropology 122:1-10. 
Dahlén G (2002) Microbiology and treatment of dental abscesses and periodontalendodontic lesions. Periodontology 2000 28:206-239.

Davinson JM, Rose JC, Gutmann MP, Haines MR, Condon K, and Condon C (2002) The quality of african-american life in the old southwest near the turn of the twentieth century. In RH Steckel and JC Rose (eds.): The backbone of history: health and nutrition in the western hemisphere. Cambridge: Cambridge University Press, pp. 226-277.

Douglas MT, Pietrusewsky M, and Ikehara-Quebral RM (1997) Skeletal biology of Apurguan: a precontact Chamorro site on Guam. American Journal of Physical Antropology 104:291-313.

Dransart P (1991) Llamas, herders and the exploitation of raw materials in the Atacama desert. World Archaeology 22:304-319.

Duray SM (1990) Deciduous enamel defects and caries suscebility in a prehistoric Ohio population. American Journal of Physical Anthropology 81:27-34.

El-Najjar MY, Ryan DJ, Turner II CG, and Lozoff B (1976) The etiology of porotic hyperostosis among the prehistoric and historic Anasazi indians of southwestern United States. American Journal of Physical Anthropology 44:477-487.

Ember CR, and Ember M (1998) Anthropology: a brief introduction. New Jersey: PrenticeHall, Inc.

Erdal YS, and Duyar I (1999) Brief communication: a new correction procedure for calibrating dental caries frequency. American Journal of Physical Anthropology 108:237240.

Erickson CL (1992) Prehistoric landscape management in the Andean in the Andean Highlands: raised field agriculture and its environmental impact. Population and Environment 13:285-300.

Formicola V (1987) Neolithic transition and dental changes: the case of an Italian site. Jornal of Human Evolution 16:231-239.

Frank AG (1967) Capitalism and underdevelopment in Latin America: historical studies of Chile and Brazil. New York: Monthly Review Press.

Glória, PJT, Neves WA, Costa MA, and Bartolomucci R (submetido) Nonspecific enfectious disease in prehistoric San Pedro de Atacama, northern Chile. Chungará.

Goodman AH, Allen LH, Hernandez GP, Amador A, Arriola LV, Chaves A, and Pelto GH (1987) Prevalence and Age at development of enamel hypoplasias in mexican children. American Journal of Physical Anthropology 72:7-19. 
Goodman AH (1993) On the interpretation of health from skeletal remains. Current Anthropology 34:281-288.

Goodman AH, and Martin DL (2002) Reconstructing health profiles from skeletal remains. In RH Steckel and JC Rose (eds.): The backbone of history: health and nutrition in the western hemisphere. Cambridge: Cambridge University Press, pp. 11-60.

Goodman AH, and Rose JC (1990) Assessment of systemic physiological perturbations from dental enamel hypoplasias and associated histological structures. Yearbook of Physical Anthropology 33:59-110.

Goodman AH, Martin DL, Armelagos GJ and Clarke GA (1984) Indications of stress from bones and teeth. In: Cohen M, Armelagos GJ. Paleopathology at the origins of agriculture. New York: Academic Press. p 13-49.

Goodman AH, Thomas RB, Swedlund AC, and Armelagos GJ (1988) Biocultural perspectives on stress in prehistoric, historical, and contemporary population research. Yearbook of Physical Anthropology 31:169-202.

Graffam G (1992) Beyond state collapse: rural history, raised fields, and pastoralism in the South Andes. American Anthropologist 94:882-904.

Grauer AL, and Roberts CA (1996) Paleoepidemiology, healing, and possible treatment of trauma in the medieval cemetery population of St. Hlen-on-the-Walls, York, England. American Journal of physical Anthropology 100:531-544.

Hall RL, Morrow R, and Clarke JH (1986) Dental pathology of prehistoric residents of Oregon. American Journal of Physical Anthropology 69:325-334.

Hanson DB, and Butler BM (1997) A biocultural perspective on Marianas prehistory: recent trends in bioarchaeological research. American Journal of Physical Antropology 104:271-290.

Haubert F, Krever MLB, Palma LP, and Schimitz PI (2004) Bocas e dentes: o estudo dos esqueletos escavados por Pe. João Alfredo Rohr S.J. no litoral de Santa Catarina. Documentos - Arqueologia do Rio Grande do Sul, Brasil, 9 .

Hillson S (1996) Dental Anthropology. Cambridge: Cambridge University Press.

Hillson S, and Bond S (1997) Relationship of enamel hypoplasia to the pattern of tooth crown growth: a dicussion. American Journal of physical Anthropology 104:89-103.

Higgins RL, Haines MR, Walsh L, and Sirianni JE (2002) The poor in the mid-nineteenthcentury northeastern United States: evidence from the Monroe County Almhouse, Rochester, New York. In RH Steckel and JC Rose (eds.): The backbone of history: health 
and nutrition in the western hemisphere. Cambridge: Cambridge University Press, pp. 162184.

Hinton RJ (1981) Form and patterning of anterior tooth wear among aboriginal human groups. American Journal of Physical Anthropology 54:555-564.

Hodges DC (1987) Health and agricultural intensification in the prehistoric valley of Oaxaca, Mexico. American Journal of Physical Anthropology 73:323-332.

Holden TG (1991) Evidence of prehistoric diet from northern Chile: coprolites, gut contents and flotation samples from the Tulán quebrada. World Archaeology 22:320-331.

Holland TD, and O'Brien MJ (1997) Parasites, porotic hyperostosis, and the implications of changing perspectives. American Antiquity 62:183-193.

Hooton EA (1930) The indians of Pecos Pueblo: a study of their skeletal remains. New Haven: Yale University Press.

Huss-Ashmore R, Goodman AH, and Armelagos GJ (1982) Nutritional inference from paleopathology. Advances in Archaeological Method and Theory 5:395-474.

Hutchinson DL, and Larsen CS (1988) Determination of stress episode duration from linear enamel hypoplasias: a case study from St. Catherines Island, Georgia. Human Biology 60:93-110.

Indriati E, and Buikstra JE (2001) Coca chewing in prehistoric coastal Peru: dental evidence. American Journal of Physical Anthropology 114:242-257.

Inhorn MC, and Brown PJ (1990) The anthropology of infectious disease. Annual Review of Anthropology 19:89-117.

Irons W, and Cronk L (2000) Two decades of a new paradigm. In: Cronk L, Chagnon N, Irons W, editors. Adaptation and human behavior: an anthropological theory. New York: Aldine and Gruyer. p 3-26.

Jackes M (1993) On paradox and osteology. Current Anthropology 34:434-439.

Janusek JW (1999) Craft and local power: embedded specialization in Tiwanaku cities. Latin America Antiquity 10:107-131.

Janusek JW (2002) Out of many, one: style and social boundaries in Tiwanaku. Latin American Antiquity 13:35-61.

Janusek JW, and Kolata AL (2004) Top-down or bottom-up: rural settlement and raised field agriculture in the Lake Titicaca Basin, Bolivia. Journal of Anthropological Archaeology 23:404-430.

Jarcho S, editor (1966) Human palaeopathology. New Haven: Yale University Press. 
Jennings J (2006) Core, peripheries, and regional realities in Middle Horizon Peru. Journal of Anthropological Archaeology in press.

Johansson SR, and Owsley D (2002) Welfare history on the Great Plains: mortality and skeletal health, 1650 to 1900. In RH Steckel and JC Rose (eds.): The backbone of history: health and nutrition in the western hemisphere. Cambridge: Cambridge University Press, pp. 524-560.

Judd MA, and Roberts CA (1999) Fracture trauma in a Medieval british farming village. American Journal of Physical Anthropology 109:229-243.

Kaifu Y (1999) Changes in the pattern of tooth wear from prehistoric to recent periods in Japan. American Journal of Physical Anthropology 109:485-499.

Katzenberg MA, Herring DA, and Saunders SR (1996) Weaning and infant mortality: evaluating the skeletal evidence. Yearbook of Physical Anthropology 39:177-199.

Keenleyside A (1998) Skeletal evidence of health and disease in pre-contact Alaskan Eskimos and Aleuts. American Journal of Physical Antropology 107:51-70.

Kelley JO, and Angel JL (1987) Life stresses of slavery. American Journal of Physical Anthropology 74:199-211.

Kent S (1986) The influence of sedentism and aggregation on porotic hyperostosis and anaemia: a case study. Man 21:605-636.

Kolata AL (1986) The agricultural foundations of the Tiwanaku state: a view from the heartland. American Antiquity 51:748-762.

Kolata AL (1991) The tecnology and organization of agricultural production in the Tiwanaku state. Latin American Antiquity 2:99-125.

Kolata AL (1993) The Tiwanaku: portrait of an andean civilization. Cambridge: Blackwell.

Lambert PM (1993) Health in prehistoric populations of the Santa Barbara Channel Islands. American Antiquity 58:509-522.

Lanphear KM (1990) Frequency and distribution of enamel hypoplasias in a historic skeletal sample. American Journal of Physical Anthropology 81:35-43.

Larsen CS (1983) Behavioural implications of temporal change in cariogenesis. Journal of Archaeological Science 10:1-8.

Larsen CS (1997) Bioarchaeology: interpreting behavior from the human skeleton. Cambridge: Cambridge University Press. 
Larsen CS, Crosby AW, Griffin MC, Hutchison DL, Ruff CB, Russell KF, Shoeninger MJ, Sering LE, Simpson SW, Takács JL, and Teaford MF (2002) A biohistory of health and behavior in the Georgia Bight: the agricultural transition and the impact of european contact. In RH Steckel and JC Rose (eds.): The backbone of history: health and nutrition in the western hemisphere. Cambridge: Cambridge University Press, pp. 406-439.

Lekson SH (2002) War in the southwest, war in the world. American Antiquity 67:607624.

Lévi-Strauss C (2003 [1949]) As estruturas elementares do parentesco. $3^{\mathrm{a}}$ ed. Petrópolis: Editora Vozes.

Lewis ME (2002) Impact of industrialization: comparative study of child health in four sites from medieval and postmedieval England (A.D. 850-1859). American Journal of Physical Anthropology 119:211-223.

Littleton J, and Frohlich B (1993) Fish-eaters and farmers: dental pathology in the Arabian Gulf. American Journal of Physical Anthropology 92:427-447.

Llagostera A (1995) El componente cultural Aguada en San Pedro de Atacama. Boletin del Museo Chileno de Arte Precolombino 6:9-34.

Llagostera A (1996) San Pedro de Atacama: nodo de complementaridad reticular. Estudios y Debates Regionales Andinos 91:17-42.

Llagostera A (2004) Los antiguos habitantes del Salar de Atacama: prehistoria atacameña. Santiago: Pehuén Editores.

Llagostera A, and Costa MA (1999) Patrones de asentamiento en la epoca agroalfarera de San Pedro de Atacama (norte de Chile). Estudios Atacameños 17:175-206.

Llagostera A, Torres CM, and Costa MA (1988) El complejo psicotrópico en Solcor-3 (San Pedro de Atacama). Estudios Atacameños 9:61-98.

Lovejoy CO, and Heiple KG (1981) The analysis of fractures in skeletal population, with an example from the Libben site, Ottowa County, Ohio. American Journal of Physical Anthropology 55:529-541.

Lovell NC (1997) Trauma analysis in paleopathology. Yearbook of Physical Anthropology 40:139-170.

Lovell NC, and Whyte I (1999) Patterns of dental enamel defects at Ancient Mendes, Egypt. American Journal of Physical Anthropology 110:69-80.

Lubell D, Jackes M, Schwarcz H, Knyf M, and Meiklejohn C (1994) The mesolithicneolithic transition in Portugal: isotopic and dental evidence of diet. Journal of Archaeological Science 21:201-216. 
Lukacs JR (1992) Dental paleopathology and agricultural intensification in South Asia: new evidence from Bronze Age Harappa. American Journal of Physical Anthropology 87:133-150.

Lukacs JR (1996) Sex differences in dental caries rates with the origin of agriculture in South Asia. Current Anthropology 37:147-153.

Lukacs JR, and Pal JN (1993) Mesolithic subsistence in North India: inferences from dental attributes. Current Anthropology 34:745-765.

Lynch TF (1975) Algunos problemas basicos del estadio de caza-recoleccion andina: transhumancia. Estudios Atacaneños 3:7-10.

Maat GJR, and Van der Velde EA (1987) The caries-attrition competition. International Journal of Anthropology 2:281-292.

Machado LMC, and Sene GC (2001) Simbolismo, identidade cultural e análise biológica: os remanescentes esqueletais humanos do sambaqui da Tarioba. Anais do I Encontro de Arqueologia da Costa Norte Fluminense :51-79.

Madrigal L (1998) Statistics for anthropology. Cambridge: Cambridge University Press.

Malinowski B (1998 [1922]) Argonautas do pacífico ocidental. São Paulo: Abril Cultural. Neves WA, Hubbe M, and Costa MA (2000) Marcadores dentários de dieta e mudança social em San Pedro de Atacama, Chile. VI Congreso de la Asociación latino Americana de Antropologia Biológica.

Malville NJ (1997) Enamel hypoplasia in ancestral puebloan populations from southwestern Colorado: I. permanent dentition. American Journal of physical Anthropology 102:351-367.

Mauss M (1974 [1923-24]) Ensaio sobre a dádiva. Forma e razão da troca nas sociedades arcaicas. In: Sociologia e antropologia. v. II. São Paulo: Edusp.

Meiklejohn C, Wyman JM, and Schentag CT (1992) Caries and atrition: dependent or independent variables? International Journal of Anthropology 7:17-22.

Melbye J, and Fairgrieve SI (1994) A massacre and possible canibalism in the canadian arctic: new evidence from the Saunaktuk site (NgTn-1). Arctic Anthropology 31:57-77.

Mello e Alvim MC, and Gomes JCO (1989) Análise e interpretação da hiperostose porótica em crânios humanos do sambaqui de Cabeçuda (SC - Brasil). Revista de Pré-História 7:127-145.

Mello e Alvim MC, and Uchôa DP (1996) Hiperostose porótica em crânios de índios mulatos do sudeste brasileiro: correlação entre as lesões na calvaria e na órbita. Revista do 
Museu de Arqueologia e Etnologia 6:155-168.

Mello e Alvim MC, Uchôa DP, and Gomes JCO (1991) Criba orbitalia e lesões cranianas congêneres em populações pré-históricas da costa meriodional do Brasil. Revista do Museu de Arqueologia e Etnologia 1:21-53.

Mendonça de Souza SMF (1995) Estresse, doença e adaptabilidade: estudo comparativo de dois grupos pré-históricos em perspectiva bio-cultural. Tese de Doutorado, Escola Nacional de Saúde Pública/ FIOCRUZ, Rio de Janeiro.

Milner GR, Anderson E, and Smith VG (1991) Warfare in late prehistoric west-central Illnois. American Antiquity 56:581-603.

Moffat T (2003) Diarrhea, respiratory infections, protozoan gastrointestinal parasites, and child growth in Kathmandu, Nepal. American Journal of Physical Anthropology 122:85-97.

Molnar S (1971) Human tooth wear, tooth function and cultural variability. American Journal of Physical Anthropology 34:175-189.

Molnar S, and Molnar I (1985) Observations of dental diseases among prehistoric populations of Hungary. American Journal of Physical Anthropology 67:51-63.

Moodie RL (1923) Paleopathology: an introduction to the study of ancient evidences of disease. Urbana: University Illnois Press.

Murra JV (1972) El control vertical de un máximo de pisos ecológicos en la economia de las sociedades andinas. In JV Murra (ed.): Visita de la provincia de León de Huánuco en 1562 por Iñigo Ortiz de Zúñiga. Huánuco, pp. 427-476.

Nathan H, and Hass N (1966) On the presence of cribra orbitalia in apes and monkeys. American Journal of Physical Anthropology 24:351-360.

Nelson GC, Lukacs JR, and Yule P (1999) Dates, caries, and early tooth loss during the Iron Age of Oman. American Journal of Physical Anthropology 108:333-343.

Neves WA (1984) Estilo de vida e osteobiografia: a reconstituição do comportamento pelos ossos humanos. Revista de Antropologia 6:287-291.

Neves WA, and Costa MA (1998) Adult stature and standard of living in the prehistoric Atacama Desert. Current Anthropology 39:278-281.

Neves WA, and Costa MA (1999) Nutrition and quality of life in prehistoric San Pedro de Atacama, Chile. Antropología Física Latinoamericana 2:23-39.

Neves WA, Barros AM, and Costa MA (1999) Incidence and distribution of postcranial fractures in the prehistoric population of San Pedro de Atacama, northern Chile. American Journal of Physical Anthropology 109:253-258. 
Núñez L (1992) Cultura y conflicto en los oasis de San Pedro de Atacama. Santiago do Chile: Editorial Universitaria.

Núñez L (1995) Evolución de la ocupación y organización del espacio atacameño. In P Pourrut and L Núñez (eds.): Agua, ocupación del espacio y economía campesina en la región atacameña: aspectos dinámicos. Antofagasta, Chile: Universidad Católica del Norte, pp. 18-60.

Núñez L, and Dillehay T (1979) Movilidad giratoria, armonía social e desarrollo en los Andes Meridionales: patrones de tráfico e interacción económica. Antofagasta: Universidad del Norte.

Núñez L, Grosjean M, and Cartajena I (2002) Human occupations and climate change in the Puna de Atacama, Chile. Science 5594:821-824.

Ortloff CR, and Kolata AL (1993) Climate and collapse: agro-ecological perspectives on the decline of the Tiwanaku state. Journal of Archaeological Science 20:195-221.

Ortner DJ, and Putschar WGJ (1981) Identification of pathological conditions in human skeletal remains. Washington, D.C.: Smithsonian Institution Press.

Pechenkina EA, Benfer Jr. RA, and Zhijun W (2002) Diet and health changes at the end of the Chinese Neolithic: the Yangshao/Longshan transition in Shaanxi province. American Journal of Physical Anthropology 117:15-36.

Pietrusewsky M, Douglas MT, and Ikehara-Quebral RM (1997) An assessment of health and disease in the prehistoric inhabitants of the Mariana Islands. American Journal of Physical Antropology 104:315-342.

Rappaport RA (1968) Pigs for the ancestor. New Haven: Yale University Press.

Rathbunn TA (1987) Health and disease at a South Carolina plantation: 1840-1870. American Journal of Physical Anthropology 74:239-253.

Reid DJ, and Dean MC (2000) Brief communication: the timing of linear hypoplasias on human anterior teeth. American Journal of Physical Anthropology 113:135-139.

Rodman AO (1992) Textiles and ethnicity: Tiwanaku in San Pedro de Atacama, north Chile. Latin American Antiquity 3:316-340.

Rodrigues C (1997) Perfis dento-patológicos nos remanescentes esquletais de dois sítios pré-históricos brasileiros: o cemitério de Furna de Estrago e o sambaqui de Cabeçuda. Dissertação de Mestrado, Escola Nacional de Saúde Pública/ Fundação Oswaldo Cruz, Rio de Janeiro. 
Ryan AS (1997) Iron-deficience anemia in infant development: implications for growth, cognitive development, resistance to infection, and iron supplementation. Yearbook of Physical Antropology 40:25-62.

Santos RV, and Coimbra Jr CEA (1999) Hardships of contact: enamel hypoplasias in TupíMondé amerindians from the Brazilian Amazonia. American Journal of Physical Anthropology 109:111-127.

Saunders SR, De Vito C, and Katzenberg MA (1997) Dental caries in nineteenth century Upper Canada. American Journal of physical Anthropology 104:71-87.

Saunders SR, and Hoppa RD (1993) Growth deficit in survivors and non-survivors: Biological mortality bias in subadult skeletal samples. Yearbook of Physical Anthropology 36:127-151.

Schneider KN (1986) Dental caries, enamel composition, and subsistence among prehistoric amerindians of Ohio. American Journal of Physical Anthropology 71:95-102.

Schollmeyer KG, and Turner II CG (2004) Dental caries, prehistoric diet, and the Pithouseto-Pueblo transition in Southwestern Colorado. American Antiquity 69:569-582.

Sciulli PW, and Oberly J (2002) Native Americans in Eastern North America: the Southern Great Lakes and Upper Ohio Valley. In RH Steckel and JC Rose (eds.): The backbone of history: health and nutrition in the western hemisphere. Cambridge: Cambridge University Press, pp. 440-480.

Scott EC (1979) Dental wear scoring technique. American Journal of Physical Anthropology 51:213-218.

Scott GR, and Turner II CG (1988) Dental Anthropology. Annual Review of Anthropology 17:99-126.

Sealy JC, Patrick MK, Morris AG, and Alder D (1992) Diet and dental caries among later stone age inhabitants of the Cape Province, South Africa. American Journal of Physical Anthropology 88:123-134.

Selye H (1956) The stress of life. New York: McGraw-Hill.

Selye H (1973) The evolution of the stress concept. American Scientist 61:692-699.

Serracino G (1980) Tiwanaku desde San Pedro de Atacama. Estudios Arqueológicos 5:95106.

Sheridan SG, Mittler DM, Van Gerven DP, and Covert HH (1991) Biomechanical association of dental and temporomandibular pathology in a medieval Nubian population. American Journal of Physical Anthropology 85:201-205. 
Slaus M (2000) Biocultural analysis of sex differences in mortality profiles and stress levels in the late medieval population from Nova Raca, Croatia. American Journal of Physical Anthropology 111:193-209.

Sledzink PS, and Sandberg LG (2002) The effects of nineteenth-century military service on health. In RH Steckel and JC Rose (eds.): The backbone of history: health and nutrition in the western hemisphere. Cambridge: Cambridge University Press, pp. 185-207.

Smith BH (1984) Patterns of molar wear in hunter-gatherers and agriculturalists. American Journal of Physical Anthropology 63:39-56.

Smith EA (2000) Three styles in the evolutionary analysis of human behavior. In: Cronk L, Chagnon N, Irons W, editors. Adaptation and human behavior: an anthropological theory. New York: Aldine and Gruyer. p 27-46.

Smith MO (2003) Beyond palisades: the nature and frequency of late prehistoric deliberate violent trauma in the Chickamauga reservoir of east Tennessee. American Journal of Physical Anthropology 121:303-318.

Souza SMFM (1999) Osteologia humana, paleopatologia e inferência arqueológica: uma reflexão sobre o valor dos dados. In JML Mazz and M Sans (eds.): Arqueologia y bioantropologia de las tierras bajas: Universidad de la República. Faculdad de Humanidades y Ciencias de la Educación, pp. 189-204.

Standen VG, and Arriaza BT (2000) Trauma in the preceramic coastal populations of Northern Chile: violence or occupational harzards? American Journal of Physical Anthropology 112:239-249.

Stanish C (1994) The hydraulic hypothesis revisited: lake Titicaca basin raised fields in theoretical perspective. Latin American Antiquity 5:312-332.

Steckel RH (1995) Stature and the standard of living. Journal of Economic Literature 33: 1903-1940.

Steckel RH, and Rose JC (2002) The backbone of history: health and nutrition in the western hemisphere. Cambridge: Cambridge University Press.

Steckel RH, Rose JC, Larsen CS, and Walker PL (2002) Skeletal health in the western hemisphere from 4000 B.C. to the present. Evolutionary Anthropology 11:142-155.

Stein GJ (2002) From passive peripheries to active agents: emerging perspectives in the archaeology of interregional interaction. American Anthropologist 104:903-916.

Steinbock RT (1976) Palaeopathological diagnosis and interpretation. Springfield, Ill: Thomas.

Stojanowski CM, Seidemann RM, and Doran GH (2002) Differential skeletal preservation 
at Windover Pond: causes and consequences. American Journal of Physical Anthropology 119:15-26.

Storey R, Morfin LM, and Smith V (2002) Social disruption and the Maya civilization of mesoamerica: a study of health and economy of the last thousands years. In RH Steckel and JC Rose (eds.): The backbone of history: health and nutrition in the western hemisphere. Cambridge: Cambridge University Press, pp. 283-306.

Storto C, Eggers S, and Lahr MM (1999) Estudo preliminar das paleopatologias da população do sambaqui Jaboticabeiras II, Jaguaruna, SC. Revista do Museu de Arqueologia e Etnologia 9:61-71.

Stuart-Macadam P (1985) Porotic hyperostosis: representative of a childhood condition. American Journal of Physical Anthropology 66:391-398.

Stuart-Macadam P (1987) Porotic hyperostosis: new evidence to support the anemia theory. American Journal of Physical Anthropology 74:521-526.

Stuart-Macadam P (1989) Porotic hyperostosis: relationship between orbital and vault lesions. American Journal of Physical Anthropology 80:187-193.

Stuart-Macadam P (1992) Porotic hyperostosis: a new perspective. American Journal of Physical Anthropology 87:39-47.

Stuart-Macadam P, and Kent S, eds. (1992) Diet, Demography, and disease: changing perspectives on anemia. New York: Walter de Gruyter, Inc.

Sullivan A (2005) Prevalence and etiology of acquired anemia in Medieval York, England. American Journal of Physical Anthropology 128:252-272.

Tarragó MN (1989) Contribución al conocimiento arqueologico de las poblaciones de los oasis de San Pedro de Atacama en relación com los otros pueblos puneños, en especial, el sector septentrional del valle Calchaqui. Doctoral, Universidad Nacional de Rosario, Rosario.

Torres CM (1999) Psychoactive substances in the archaeology of Northern Chile and NW Argentina. A comparative review of the evidence. Chungara 30:49-63.

Torres CM, Repke DB, Chan K, McKeanna D, Llagostera A, and Schultes RE (1991) Snuff powders from pre-hispanic San Pedro de Atacama: chemical and contextual analysis. Current Anthropology 32:640-649.

Torres-Rouff C, and Costa MA (2006) Interpersonal violence in prehistoric San Pedro de Atacama, Chile: behavioral implications of environmental stress. American Journal of Physical Anthropology 130:60-70. 
Touger-Decker R, and Loveren C (2003) Sugars and dental caries. Nutrition 78(supl.):8815-8925.

Turner II CG (1979) Dental anthropological indications of agriculture among the Jomon people of central Japan. American Journal of Physical Anthropology 51:619-636.

Ubelaker DH (2000) Temporal trends in Old World patterns of morbidity. Chungará 32:3340 .

Ubelaker DH, and Newson LA (2002) Patterns of health and nutrition in prehistoric and historic Ecuador. In RH Steckel and JC Rose (eds.): The backbone of history: health and nutrition in the western hemisphere. Cambridge: Cambridge University Press, pp. 343-375.

Uribe M (2002) Sobre alfarería, cementerios, fases y procesos durante la prehistoria tardía del desierto de Atacama (800-1600 DC). Estudios Atacameños 22:7-31.

Van Gerven DP, Beck R, and Hummert JR (1990) Patterns of enamel hypoplasia in two medieval populations from Nubia's Batn El Hajar. American Journal of Physical Anthropology 82:413-420.

Varela HH, and Cocilovo JA (2000) Structure of the prehistoric population of San Pedro de Atacama. Current Anthropology 41:125-132.

Walker PL (1986) Porotic hyperostosis in a marine-dependent California Indian population. American Journal of Physical Anthropology 69:345-354.

Wallace DT (1980) Tiwanaku as a simbolic empire. Estudios Arqueológicos 5:133-144.

Wapler U, Crubézy E, and Schultz M (2004) Is cribra orbitalia synonymous with anemia? Analysis and interpretation of cranial pathology in Sudan. American Journal of Physical Anthropology 123:333-339.

Wood JW, Milner GR, Harpending HC, and Weiss KM (1992) The osteological paradox. Current Anthropology 33(4):343-370.

Wood L (1996) Frequency and chronological distribution of linear enamel hypoplasia in a North American colonial skeletal sample. American Journal of physical Anthropology 100:247-259.

Wood L (1996) Frequency and chronological distribution of linear enamel hypoplasia in a North American colonial skeletal sample. American Journal of physical Anthropology 100:247-259.

Wright LE (1997) Intertooth patterns of hypoplasia expression: implications for childhood health in the classic Maya collapse. American Journal of Physical Anthropology 102:233247. 